UNIVERSIDADE DE SÃO PAULO

FACULDADE DE ARQUITETURA E URBANISMO

Curso de Pós-graduação

\title{
FINANCEIRIZAÇÃO DA POLÍTICA HABITACIONAL: LIMITES E PERSPECTIVAS
}




\section{FINANCEIRIZAÇÃO DA POLÍTICA HABITACIONAL: LIMITES E PERSPECTIVAS}

Tese apresentada como requisito à obtenção do grau de Doutor em Arquitetura e Urbanismo, no âmbito do programa de Pós-Graduação em Arquitetura e Urbanismo, Área de Concentração do Habitat da Faculdade de Arquitetura e Urbanismo da Universidade de São Paulo.

aluna

Arq. Ms. Luciana de Oliveira Royer

orientadora

Profa Dra Ermínia Terezinha Menon Maricato

São Paulo | 2009 
AUTORIZO a reproduzir, e/ou disponibilizar na rede mundial de computadores - Internet - e permito a reprodução por meio eletrônico dessa tese a partir da data abaixo, desde que citada a fonte e o uso da reprodução e/ou disponibilização não seja para fins comerciais.

São Paulo, de de 2009.

\section{Luciana de Oliveira Royer}

ROYER, Luciana de O.

Financeirização da política habitacional: limites e perspectivas / Luciana de Oliveira Royer

- São Paulo: USP / Faculdade de Arquitetura e Urbanismo, 2009.

$194 f ; 31 \mathrm{~cm}$.

Orientador: Ermínia Terezinha Menon Maricato

Tese (doutorado) - USP / Faculdade de Arquitetura e Urbanismo, Programa de PósGraduação em Arquitetura e Urbanismo, Área de Concentração Habitat, 2009.

Referências bibliográficas: f. 166-193

1. Política habitacional. 2. Sistema Financeiro de Habitação. 3. Sistema Financeiro Imobiliário. 4. FGTS. 5. SBPE. - Tese. I. MARICATO, Ermínia T.M. II. Universidade de São Paulo, Faculdade de Arquitetura e Urbanismo, Programa de Pós-Graduação em Arquitetura e Urbanismo, Área de Concentração Habitat. III. Título. 
Dedico esta tese a quem luta pela efetivação dos direitos sociais no Brasil, especialmente do direito à moradia digna.

Dedico também a tese à memória do Prof. Dr. Jorge Hajime Oseki, que, em conjunto com outros mestres, me inflamou com o desejo de conduzir uma pesquisa acadêmica contribuindo para a construção do conhecimento coletivo, me fazendo ver a importância e o valor de uma universidade pública em um país marcado pela injustiça social. 
Agradeço a todos que contribuíram direta ou indiretamente à pesquisa que resultou nessa tese.

Em especial agradeço à minha orientadora Ermínia Terezinha Menon Maricato, pesquisadora acadêmica e profissional reconhecida, inspiradora de gerações de urbanistas e arquitetos por sua seriedade, competência e compromisso, que nunca se furtou a desafios inglórios, especialmente na sua passagem pelo governo federal, e que generosamente apoiou a continuidade dessa pesquisa e dessa tese em momentos que eu mesma já não acreditava tanto que seria possível sua conclusão.

Agradeço ainda à Caixa Econômica Federal, que me concedeu a licença para a finalização da tese, especialmente à equipe da Vice-Presidência de Governo e ao Vice-Presidente, Jorge Fontes Hereda, à equipe da Gerência de Desenvolvimento Urbano do Estado de São Paulo e à equipe da Supervisão de Parcerias e Supervisão de Assistência Técnica, que acompanharam o processo de construção da tese e apoiaram de forma inconteste sua finalização.

Ao professor doutor da Faculdade de Direito Luis Fernando Massonetto, por importantes indicações bibliograficas e infindáveis discussões sobre direito economico, individualismo metodológico e nova economia institucional.

Agradeço também aos professores participantes do exame de qualificação, Prof. Dr. Jorge Mattoso e Prof. Dr. João Whitaker Ferreira, por observações fundamentais para o andamento e conclusão da pesquisa.

Agradeço também aos competentes, extremamente pacientes e sempre companheiros assistentes de pesquisa, arquiteta Natália Gaspar e advogado Álvaro Luís dos Santos Pereira.

Aos colegas da Faculdade de Arquitetura e Urbanismo da USP, incluindo aí todos os funcionários da Pós-Graduação, bibliotecários e secretários, sempre solícitos e amigos.

À equipe do LABHAB, Laboratório de Habitação e Assentamentos Humanos da FAU-USP e também às profícuas sessões de estudos do grupo de estudos de urbanização que se reune na pós-graduação da FAU-USP.

Aos amigos queridos e companheiros, em especial às queridas amigas Bia Kara-José, Karina Leitão, Mariana Fix, Roberta Asse e Roberta Menezes.

A minha familia pelo apoio e compreensão incondicionais, proporcionando as condições para o estudo e a pesquisa desde sempre.

E agradeço ainda, e mais uma vez, e sempre, muito especialmente, ao Luís, à Maria Vitória e ao Lourenço. 
A partir de análise de dados primários oriundos do Banco Central do Brasil e da Caixa Econômica Federal, bem como da análise de literatura relacionada, o trabalho busca compreender alguns resultados da política de crédito habitacional sob o ponto de vista da universalização da habitação enquanto direito, analisando os principais fundings da política, o SBPE e o FGTS, operando simultaneamente no Sistema Financeiro da Habitação, SFH, e no Sistema Financeiro Imobiliário, SFI. Busca também compreender o funcionamento do SFI na lógica de uma política pública de habitação.

A estrutura do SFH, ainda vigente, ganhou uma outra lógica com a aprovação em 1997 do SFI. Os avanços recentes no marco regulatório, com mudanças legais importantes, teriam contribuído para que o SFH chegasse a números recordes em anos recentes.

Apesar de todas as investidas para a montagem do SFI de forma completa, os fundos públicos e semi-públicos (ou paraestatais) ainda são o pilar da política habitacional exercida no país. Nota-se nos números recentes a importância da ampliação do crédito como ampliação do acesso das classes de menor renda ao mercado de consumo e a importância da regulação feita pelo estado para que esses números fossem alcançados.

A sofisticação financeira do SFI remete a uma discussão do modelo neoclássico de eficiência financeira que se choca com o conceito da universalização da habitação enquanto direito. Dessa forma o trabalho busca discorrer também sobre a esterilização do debate relativo a políticas públicas sob esse diapasão, visto que o discurso do senso comum é que o modelo financeiro quando bem feito é capaz de suportar qualquer política pública. A redução da política pública ao discurso financeiro resulta numa financeirização da política habitacional, com impactos negativos na universalização e no acesso ao bem habitação. 


\section{Abstract}

The current work interprets the results of the housing credit policy in terms of housing as a universal right. The analysis is based on primary data from the Central Bank of Brazil, Caixa Economica Federal, and related literature. The analysis is based on the main sources of funding: SBPE and FGTS. Both sources operate simultaneously in the Housing Financial System (SFH) and Real State Financial System (SFI). The operation of the SFI in the framework of the public housing policy is also assessed.

The current structure of the SFH acquired a new logic with the approval of the SFI in 1997. The recent advancements in the regulatory framework, with important legal modifications, have contributed to financing the SFH to achieve record numbers in recent years.

However, despite all the effort to fully assemble the SFI, public and semi-public funding sources still constitute the pillars of the housing policy in effect. The recent numbers highlight the importance of the credit expansion as a mechanism to expand the access of lower income classes to the consumer market. Also noteworthy is the importance of the government's regulation in the achievement of those numbers.

The financial sophistication of the SFI prompts the discussion of the neoclassical model of financial efficiency, which collides with the concept of housing as a universal right. In addition, the current consensus is that a financial model when well executed is able to promote any public policy. The current work also analyzes the lack of debate of public policies from this angle. The reduction of public policies to financial discourse results in the financialization of the housing policy, with negative impact in housing access and universalization. 
QUADRO 1 Estrutura básica de uma operação de securitização imobiliária, p. 110

TABELA $1 \quad$ SFH / BNH: Financiamentos habitacionais concedidos - Unidades Habitacionais e Valores - 1970 a 1986, p. 63

TABELA 2 SFH / BNH: Número de financiamentos habitacionais concedidos por ano -1980 a 1986, p. 64

TABELA $3 \quad$ SFH / BNH: Número de financiamentos habitacionais concedidos entre 1964 e julho de 1986, p. 65

TABELA 4 SFH: Evolução do número de moradias financiadas entre 1987 e 1994, p. 66

TABELA 5 SBPE: Financiamento para aquisição de Imóvel Novo, Aquisição de Imóvel Usado e Construção de Unidades Habitacionais - 1994 a 2008, p. 74

TABELA 6A Direcionamento dos recursos da poupança - Usos, p. 83

TABELA 6B Direcionamento dos recursos da poupança - Fontes, p. 83

TABELA 7 Exigibilidade do direcionamento dos recursos - Aplicações em financiamentos habitacionais efetivos, p. 84

TABELA 8A FGTS: Evolução do financiamento - 1995 a 2008, p. 90

TABELA 8B FGTS: Evolução do financiamento - 1995 a 2008, p. 91

TABELA 9 Déficit Habitacional (1) e percentual em relação aos domicílios particulares permanentes, por situação do domicílio, segundo regiões geográficas, Unidades da Federação e Regiões Metropolitanas (RMs) - Brasil - 2007, p. 155

TABELA 10 Distribuição percentual do déficit habitacional urbano (1) por faixas de renda média familiar mensal segundo regiões geográficas, Unidades da Federação e Regiões Metropolitanas (RMs) - Brasil - 2007, p. 155

TABELA 11 Critérios de inadequação dos domicílios urbanos duráveis (1), segundo regiões geográficas e Regiões Metropolitanas (RMs) - Brasil - 2007, p. 156

TABELA 12 Domicílios particulares permanentes e distribuição percentual por situação do domicílio, segundo regiões geográficas, unidades da federação e regiões metropolitanas (RMs) - Brasil -2007, p. 157 
GRÁFICO 1 SFH / BNH: Financiamentos habitacionais concedidos - Unidades Habitacionais - 1970 a 1986, p. 63

GRÁFICO 2 SFH: Evolução do número de moradias financiadas entre 1987 e 1994, p. 67

GRÁFICO 3 SBPE: Evolução do número de financiamentos concedidos entre 1994 e 2008, p. 75

GRÁFICO 4 SBPE: Evolução dos valores financiados entre 1994 e 2008, p. 76

GRÁFICO 5 SBPE: Evolução do número de financiamentos concedidos para aquisição de imóveis novos entre 1994 e 2008, p. 77

GRÁFICO 6 SBPE: Evolução do número de financiamentos concedidos para aquisição de imóveis usados entre 1994 e 2008, p. 78

GRÁFICO 7 SBPE: Evolução do número de financiamentos concedidos para construção de unidades novas entre 1994 e 2008, p. 80

GRÁFICO 8 FGTS: Evolução do número de operações - Programa Carta de Crédito - 1997 a 2008, p. 86

GRÁFICO 9 Atendimento por faixa de renda - FGTS, FAR, FDS, OGU, FAT, CAIXA e SBPE, p. 88 
ABECIP - Associação Brasileira das Entidades de Crédito Imobiliário e Poupança AMCHAM - Câmara Americana de Comércio de São Paulo

APE - Associação de Poupança e Empréstimo

BFRE - Brazil Finance and Real Estate

BID - Banco Interamericano de Desenvolvimento

BNH - Banco Nacional de Habitação

CBIC - Câmara Brasileira da Indústria da Construção

CCB - Certificado de Crédito Bancário

$\mathrm{CCl}$ - Cédulas de Crédito Imobiliário

CCFGTS - Conselho Curador do Fundo de Garantia do Tempo de Serviço

CEF - Caixa Econômica Federal

CETIP - Câmara de Custódia e Liquidação

CIBRASEC - Companhia Brasileira de Securitização

CMN - Conselho Monetário Nacional

COHAB - Companhia de Habitação

CPMI - Comissão Parlamentar Mista de Inquérito

CRI - Certificado de Recebíveis Imobiliários

CVM - Comissão de Valores Mobiliários

FAHBRE - Fundo de Apoio à Produção de Habitação para População de Baixa Renda

FAR - Fundo de Arrendamento Residencial

FAT - Fundo de Amparo ao Trabalhador

FDS - Fundo de Desenvolvimento Social

FESTA - Fundo de Estabilização

FCVS - Fundo de Compensação de Variações Salariais

FGTS - Fundo de Garantia do Tempo de Serviço

FIDC - Fundo de Investimentos em Direitos Creditórios

FII - Fundo de Investimento Imobiliário

IBGE - Instituto Brasileiro de Geografia e Estatística

IFC - International Finance Corporation

LCl - Letra de Crédito Imobiliário 
LI - Letras Imobiliárias

LTV - Loan to Value

MBS - Mortgage Backed Securities

NEI - Nova Economia Institucional

OGU - Orçamento Geral da União

OPA - Oferta Primária de Ações

OTN - Obrigação do Tesouro Nacional

PAEG - Plano de Ação Econômica do Governo

PAlH - Plano de Ação Imediata para Habitação

PEP - Programa de Empréstimo Popular

PLANHAP - Plano Nacional de Habitação Popular

PLANHAB - Plano Nacional de Habitação

PNAD - Pesquisa Nacional por Amostra de Domicílio

PND - Plano Nacional de Desenvolvimento

PROER - Programa de Estímulo à Recuperação e ao Fortalecimento do Sistema Financeiro Nacional

PROHAP - Programa de Habitação Popular

SBPE - Sistema Brasileiro de Poupança e Empréstimo

SCI - Sociedades de Crédito Imobiliário

SELIC - Sistema Especial de Liquidação e Custódia

SEPURB - Secretaria Especial de Planejamento Urbano

SERFHAU - Serviço Federal de Habitação e Urbanismo

SESC - Serviço Social do Comércio

SESI - Serviço Social da Indústria

SFH - Sistema Financeiro de Habitação

SFI - Sistema Financeiro Imobiliário

SFS - Sistema Financeiro de Saneamento

SINDUSCON - Sindicato da Indústria da Construção Civil

SPE - Sociedade de Propósito Específico

SRB - Secretaria da Receita do Brasil

UDN - União Democrática Nacional

VGV - Valor Geral de Vendas 
INTRODUÇÃO, p. 12

CAPÍTULO 1 A Financeirização do Crédito Imobiliário e o Déficit Habitacional, p. 20

1.1 A Financeirização do Crédito Imobiliário, p. 22

1.2 A Crise de 2008 nos Estados Unidos - o crédito imobiliário no banco dos réus, p. 27

1.3 A Indistinção entre Financiamento Imobiliário e Financiamento Habitacional, p. 39

CAPÍTULO 2 Estado e Mercado na Promoção da Política Habitacional: quadro histórico da evolução do crédito habitacional no Brasil, p. 45

2.1 SFH, SBPE e FGTS até o Plano Real, p. 47

2.2 SFH, SBPE e FGTS após o Plano Real, p. 69

CAPÍTULO 3 SFI, o Sistema Financeiro Imobiliário, p. 94

3.1 O SFI e as características do setor imobiliário, p. 96

3.2 O SFI e suas principais características, p. 100

3.3 Lei $n^{\circ}$. 10.931/2004 e Lei $n^{\circ}$. 11.196/2005: o aperfeiçoamento do ambiente regulatório, p. 117

3.4 Resoluções do CMN e Instruções Normativas da SRB: regras e parâmetros para a operação do mercado de títulos de crédito imobiliário, p. 121

3.5 SFI e o SFH, p. 127

CAPÍTULO 4 Tensões e Contradições do Sistema Financeiro Imobiliário

4.1 A Matriz Ideológica do Sistema Financeiro Imobiliário - SFI, p. 131

4.2 A Matriz Teórica do Sistema Financeiro Imobiliário - SFI, p. 134

4.3 O SFI e a agenda neoinstitucional, p. 138

4.4 Características da Urbanização Brasileira e o Déficit Habitacional, p. 150

CONCLUSÃO, p. 159

BIBLIOGRAFIA, p. 166 
INTRODUÇÃO 
As profundas transformações do padrão de acumulação capitalista nas últimas décadas e a disseminação das finanças como matriz de organização da riqueza em escala mundial impuseram uma nova racionalidade ao desenho institucional das políticas públicas, tanto nos países do centro quanto nos países subdesenvolvidos. A crise fiscal do Estado, associada à reestruturação da apropriação do excedente no sistema mundial, implicou uma inflexão substantiva na trajetória de reconhecimento de direitos e na oferta estatal de bens e serviços públicos. A política habitacional, como política pública voltada à efetivação do direito à moradia, não escapou deste movimento. Inicialmente compreendida como uma política de bem estar, a provisão habitacional migrou paulatinamente do discurso universalista dos direitos fundamentais para a lógica seletiva dos mercados, articulando-se de maneira inovadora com a arquitetura financeira dos novos padrões de acumulação do capital, especialmente nos Estados Unidos da América. David Harvey aponta, como um dos aspectos do novo regime de acumulação, uma predominância dos processos de acumulação por espoliação sobre a acumulação via reprodução ampliada do capital.

Neste sentido, é possível afirmar que os padrões de financiamento da política habitacional traduzem o movimento de transformação dos padrões de acumulação capitalista. Na fase de expansão material do sistema capitalista no século XX, o fundo público, nos países desenvolvidos, constituía a principal fonte de financiamento da política habitacional. O direito à moradia, ao menos nos Estados de Bem-Estar Social, compunha os custos da reprodução da força de trabalho e o fundo público operava positivamente na organização política da acumulação através da atribuição de salários indiretos. A partir da década de 70, já na fase de expansão financeira do sistema mundial, a crise fiscal e a insuficiência dos fundos administrados pelo Estado esvaziaram a sustentação estatal das políticas de bem-estar, deslocando para o mercado o atendimento das necessidades básicas da classe trabalhadora. O orçamento público e os fundos financeiros do Estado deixaram de ser responsáveis pela universalização das políticas públicas, limitando-se ao atendimento de demandas focalizadas e ao fomento das economias de mercado. Alguns autores afirmam mesmo que o orçamento fiscal do Estado passa a ser direcionado também para garantir a 
rentabilidade de aplicações financeiras de investidores privados.

Na periferia do sistema mundial, observadas as peculiaridades do capitalismo tardio e as dificuldades de formatação de um Estado de Bem-Estar auto-suficiente fora do centro do sistema, tal inflexão fez-se sentir de maneira bastante profunda. No Brasil, onde as insti-tuições que moldam a política habitacional refletem com muita consistência o padrão de modernização conservadora trilhado pelo país desde 1964, a crise de financiamento do Estado serviu de pretexto para conter as aspirações transformadoras embutidas na efetivação dos direitos sociais, especialmente no âmbito da Assembléia Nacional Constituinte, reduzindo o projeto nacional de desenvolvimento ao aperfeiçoamento das instituições de mercado e à inclusão seletiva de cidadãos no sistema de crédito direcionado.

A estrutura de financiamento da habitação criada após o golpe militar de 1964 buscou criar condições para o desenvolvimento de um mercado imobiliário que já se mostrava dinâmico. Do ponto de vista institucional, é inequívoco o êxito da política empreendida a partir de 64. Quanto aos resultados, a literatura é bastante contundente ao apontar o descasamento entre o desenvolvimento de um mercado de unidades habitacionais, voltadas principalmente à demanda de classe média, e a garantia da moradia como direito universal. Nesta perspectiva, o êxito daquela política pode ser identificado com a criação do Sistema Financeiro de Habitação (SFH), o Sistema Brasileiro de Poupança e Empréstimo (SBPE) e o Fundo de Garantia do Tempo de Serviço (FGTS), canalizando parte significativa dos recursos da poupança voluntária e compulsória à formação de um funding habitacional. Por outro lado, é inegável o caráter concentrador de renda daquela política, com a destinação de unidades subsidiadas a segmentos médios e altos da população e a apropriação de parte dos recursos pelo setor empresarial ligado à construção civil e pelos grupos rentistas.

O aprofundamento da crise do Estado e o entusiasmo neoliberal provocaram uma mudança significativa no modelo do SFH durante a década de 90. Inspirado no modelo norte-americano, centrado na captação de recursos privados via mercado de capitais, foi lançado, em 1997, o Sistema de Financiamento Imobiliário (SFI), apor- 
tando a racionalidade das finanças na organização do financiamento da política de crédito imobiliário, inclusive o ha-bitacional. Ao contrário do sistema anterior, apoiado em um funding público, o SFI buscava deslanchar o crédito imobiliário com o uso de instrumentos financeiros inovadores como o Certificado de Recebíveis Imobiliários (CRI), a Letra de Crédito Imobiliário (LCI) e a Cédula de Crédito Imobiliário (CCl), buscando introduzir, ainda que em menor escala, um mercado de financiamento habitacional semelhante ao modelo norte-americano, provendo as condições necessárias ao desenvolvimento de um mercado secundário de hipotecas, que teria como função primordial transformar a concessão de crédito imobiliário num investimento dotado de segurança e liquidez.

Neste sentido, a evolução dos modelos de financiamento da política habitacional não pode ser compreendida sem levar em conta os processos históricos de redefinição dos fluxos de riqueza na economia mundial, bem como o resgate do pacto oligárquico que sustentou a expansão financeira do sistema a partir dos anos 70. No Brasil, em especial, a montagem do SFI teve como justificativa a necessidade de construção de padrões alternativos para o financiamento das políticas públicas, informadas pelas severas restrições da política fiscal e pelos limites do endividamento externo. Assim, ao mesmo tempo em que a Constitui-ção acenava para o reconhecimento de novos direitos e para a construção de estratégias de efetivação dos direitos sociais, a conjuntura histórica direcionava os esforços da política econômica para as reformas institucionais predicadas pelo discurso da 'austeridade fiscal' permanente.

Apesar de questionar em seus pressupostos o suporte público de financiamento do SFH, o SFI não obteve o êxito imaginado por seus idealizadores nos seus primeiros anos de funcionamento. Mesmo com inúmeras tentativas, as condições macroeconômicas do país e, principalmente, a política de elevadíssimas taxas de juros sustentada pelo Banco Central dificultaram a implementação do novo sistema. Afinal, como construir um mercado secundário de hipotecas diante do alto retorno e pouco risco dos títulos do tesouro nacional? Como oferecer ao mercado taxas atrativas diante da política monetária do governo federal? 
Mas o insucesso da implantação do padrão norte-americano de financiamento imobiliário e habitacional não significou o esvaziamento do SFI. Ao contrário, em mais de dez anos de operação, o SFI foi responsável pela disseminação de um ambiente institucional tido como o mais seguro e eficiente na alocação dos recursos destinados à atividade imobiliária. A tal ponto que a política de crédito direcionado do SFH passou a ser criticada como um excesso de intervenção do estado no domínio econômico, responsável por travar o desenvolvi-mento do mercado privado de crédito no país.

Nesta perspectiva, o êxito do SFI, como arquitetura de financiamento do crédito imobiliário, deve ser analisado sob um duplo enfoque. De um lado, é importante aferir o sucesso do SFI como instituição, isto é, como um novo ambiente de negócios imobiliários, fundado na captação de recursos no mercado e na afirmação do protagonismo dos agentes privados na condução dos financiamentos. De outro, é preciso avaliar a capacidade do SFI atacar, de modo efetivo, o problema do déficit habitacional, dada as especificidades do processo de urbanização brasileiro e as necessidades habitacionais da nossa sociedade.

O âmago do presente trabalho é demonstrar a ineficiência do SFI como modelo de financiamento apto a estruturar políticas habitacionais universalizantes e a sua vocação para a captura do crédito imobiliário em favor dos grupos de maior poder aquisitivo.

No primeiro capítulo do trabalho, buscamos trabalhar uma questão premente na estruturação do crédito imobiliário - a função da habitação como ideologia justificadora da introdução de novos instrumentos financeiros para a manipulação do sistema de crédito. Para tanto, partimos do processo histórico que alterou a natureza do padrão de riqueza no capitalismo contemporâneo, dando destaque às formas financeiras de acumulação do capital.

A partir da crise de 2008, que sinalizou a confusão entre o crédito habitacional, o crédito imobiliário e a expansão do crédito ao consumo nos Estados Unidos, buscamos apontar as tendências do sistema de crédito imobiliário, bem como dos padrões regulatórios que sustentam a expansão financeira do capitalismo. Crise dos 
subprimes, bolha imobiliária, crise das hipotecas - diversas expressões para designar

uma mesma crise, que levou bancos tradicionais a encerrarem suas atividades e fez a bolsa norteamericana protagonizar quedas espetaculares, comparáveis à crise de 1929. O que faria o crédito imobiliário envolvido nessa crise? Por que a origem da crise fora imputada à falta de capacidade de pagamento dos mutuários, com a vei-culação pela televisão de imagens de pessoas e famílias perdendo suas casas? Qual o real papel da habitação na expansão da bolha que deu origem à crise de 2008? Qual a relação entre crédito imobiliário, crédito habitacional e real estate? São apenas estruturas vocacionadas para distintas funções ou teria algo a mais na operação desta semântica confusa? Neste sentido, buscamos trabalhar sobre os conceitos de crédito imobiliário, crédito habitacional e real estate, tentando separar conceitos tratados de maneira indistinta com o propósito de difundir globalmente o arranjo institucional mais adequado à acumulação financeira do capital.

No capítulo 2, procuramos analisar a evolução do crédito habitacional no Brasil, identificando o papel do Estado e do mercado na promoção de uma política habitacional baseada na concessão de crédito. De forma a tornar mais clara a análise dos números envolvidos, dividimos o capítulo em duas partes: na primeira, analisamos a política até o Plano Real e, na segunda, suas inflexões após o Plano, verificando, neste último caso, com um pouco mais de detalhe, os resultados do SBPE e do FGTS nos últimos seis anos. Além disso, apresentamos uma breve história do crédito imobiliário para fins habitacionais nos últimos quarenta anos, destacando o papel central dos fundos paraestatais como o FGTS e o SBPE.

No capítulo 3, aprofundamo-nos na questão específica do Sistema Financeiro Imobiliário (SFI), analisando suas principais características e sua relação com as principais características do setor imobiliário. Neste contexto, demos enfoque aos dois principais pilares do novo sistema - as garantias, como a alienação fiduciária, e a captação de recursos no mercado de capitais, como o processo de securitização. Também analisamos os recentes marcos legais que impulsionaram inclusive a contratação no âmbito do SFH, as leis n. 10.931/2004 e n. 11.196/2005, as resoluções do Conselho Monetário Nacional (CMN) e outras normas que forneceram parâmetros regulatórios para a operação do mercado de títulos de crédito imobiliário. Por fim, iniciamos 
a análise do funcionamento simultâneo dos dois sistemas, mostrando que, na ver-

dade, não se trata da substituição simples de um padrão de financiamento por outro, como parece sugerir uma leitura dos documentos que advogam a adoção total e irrestrita do SFI em todas as modalidades de crédito imobiliário. Trata-se, na realidade, do estabelecimento de uma relação de dependência na qual o desenvolvimento do SFI parece só se concretizar com a utilização dos recursos do SFH, especialmente para a emissão primária de hipotecas, ou seja, para a produção e ou financiamento de empreendimentos que posteriormente terão seus créditos securitizados.

No capítulo 4, analisamos, a partir dos capítulos anteriores, as tensões e contradições do SFI, procurando desvendar a sua matriz ideológica, bem como os motivos da minimização do papel do Estado, ao menos no nível do discurso, visando reforçar e solidificar o papel do mercado como o único capaz de prover recursos para um sistema de financiamento imobiliário e habitacional de forma a atingir o enorme desafio do déficit habitacional brasileiro.

Ao estudarmos também a matriz teórica do SFI destacamos sua filiação à nova economia institucional, e à defesa da 'construção' de instituições específicas para o desenvolvimento das economias de mercado, limitando o papel do Estado ao fomento do mercado e das condições reais para o seu livre funcionamento. Não por outro motivo, é este o lema do Banco Mundial que, desde 2000, vem propugnando para todos os países emergentes uma agenda de crescimento voltada ao "building institutions for markets".

No entanto, é em um país caracterizado pela enorme desigualdade social, marcado pela injustiça social visível na distribuição de renda, quase totalmente urbanizado, com aproximadamente 90\% de um déficit habitacional de 6 milhões de unidades concentrado nas faixas de renda até 3 salários mínimos que essa agenda neoinstitucionalista visa se implementar. O enorme descompasso entre o discurso e a prática dessa agenda torna-se evidente, já que para o Banco Mundial e para todas as organizações "market-oriented", o problema habitacional não é exatamente uma questão de direito social, mas sim um problema de crédito, de renda, enfim, um problema individual do cidadão consumidor. Neste modelo, inverte-se a relação 
de instrumentalidade anteriormente existente entre o financeiro e o produtivo, de modo que o primeiro deixa de ser enfocado como um meio para a viabilização do segundo, tornando-se o ponto de chegada da política habitacional.

Por fim, na Conclusão, procuramos fechar o ciclo deste trabalho, demonstrando que não é possível vencer os desafios da universalização da moradia no Brasil mercadorizando uma função constitucional do estado, tal como preconizado pelos organismos internacionais de fomento. O direito à moradia não dialoga com a mercadorização da habitação, ainda que essa tenha cada vez mais características de mercadoria no capitalismo contemporâneo. O modelo apresentado pelo SFI, tendo a habitação como uma commodity, negociada em bolsa, e tendo como pretexto o desenvolvimento de instrumentos financeiros voltados à acumulação financeira, não parece uma boa estratégia para alcançar uma cidadania social plena e para garantir a efetividade social do direito à moradia. 
CAPÍTULO 1 A Financeirização do Crédito Imobiliário e o Déficit Habitacional 
A arquitetura do financiamento habitacional no Brasil, seja aquela articulada pelo

Sistema Financeiro da Habitação - SFH, seja aquela articulada pelo Sistema Financeiro Imobiliário - SFI, deveria ter como objetivo principal o atendimento às necessidades habitacionais do país ${ }^{1}$. No entanto, nos últimos anos, o enfrentamento dessas necessidades, ou mesmo do déficit de novas unidades habitacionais, parece ter mudado de função. De meta objetiva das políticas do setor, o 'combate ao déficit', expressão largamente utilizada na mídia impressa e televisiva, tem sido utilizado como pretexto para a criação de novos instrumentos de crédito, mais vocacionados à acumulação financeira de capital que à universalização do direito à moradia.

Este fenômeno, evidentemente, não é uma exclusividade brasileira. Reflete, na verdade, o movimento de financeirização do crédito imobiliário, dentro do qual a habitação figura, na maior parte das vezes, meramente como pretexto. A recente crise econômica, que teve seu epicentro no mercado de hipotecas norte-americano, é um exemplo do fenômeno. Em pouco tempo, ficou claro que a manipulação das hipotecas pouco tinha a ver com uma política habitacional agressiva, de caráter includente, como poderia parecer aos menos desavisados. Ligava-se, objetivamente, a um processo de acumulação de capital, que tinha no sistema de crédito a sua força propulsora.

Compreender a utilização da habitação e do crédito habitacional a serviço da acumulação de capital é um grande desafio para os estudos críticos das políticas públicas do setor. De fato, é curioso observar que os instrumentos de crédito se transformaram no objetivo principal da política habitacional, independentemente de sua adequação para atacar o problema. Nesta perspectiva, o estudo dos sistemas de financiamento da habitação no Brasil não pode ignorar este desafio, oferecendo ferramentas de análise que permitam separar a efetividade social das políticas - medida pelo atendimento às necessidades habitacionais da população, do êxito na construção de um ambiente institucional favorável à acumulação de capital pelos

1 Conceito desenvolvido pela Fundação João Pinheiro a respeito da necessidade de construção de novas moradias e de melhorias nas unidades habitacionais existentes. O tema será desenvolvido no capítulo 4, mas por ora é importante salientar que o conceito de necessidades habitacionais é mais abrangente que o conceito econométrico de déficit habitacional. Em 'necessidades habitacionais' insere-se a questão urbana em muitas de suas dimensões, procurando dessa forma tratar a habitação não como unidade habitacional, mas como moradia, tal como propugnado na Constituição Federal. 
agentes privados.

É importante estabelecer, desde o início, que o trabalho não ignora a importância do crédito e do fomento de mercados privados para o financiamento e promoção da política habitacional. Os dados mais recentes do desenvolvimento da política habitacional no Brasil deixam muito claro que estes são instrumentos fundamentais para atacar a falta de novas unidades. No entanto, uma coisa é a utilização do crédito como mecanismo de provisão de um direito social. Outra, bem diferente, é a sua destinação como mecanismo privilegiado de acumulação de capital e redistribuição de riqueza e renda aos grupos de maior poder aquisitivo, como parece indicar a trajetória de financeirização do crédito imobiliário.

\subsection{A financeirização do crédito imobiliário}

David Harvey, ao dissertar sobre o neoliberalismo, ataca o uso distorcido do sistema de crédito como o meio mais radical de acumulação de capital. De acordo com o autor, a principal realização do neoliberalismo nos últimos trinta anos teria sido a redistribuição da riqueza e da renda para as altas esferas da classe capitalista, obra dos mecanismos que comporiam a chamada "acumulação por espoliação". A acumulação por espoliação seria a continuidade do processo denominado por Marx como acumulação primitiva de capital e seria a responsável pelo padrão da apropriação da riqueza na atual fase de organização do modo de produção capitalista. Várias práticas fariam parte deste processo, como a privatização da terra, a conversão de formas estatais e coletivas de propriedade em propriedade privada, a supressão de direitos aos bens comuns, os processos neocoloniais de apropriação privada de ativos (como os recursos naturais) e, o mais devastador de todos, o uso do sistema de crédito como meio radical de apropriação privada do excedente econômico (Harvey, 2005, p.171).

A acumulação por espoliação, assim como a acumulação primitiva de capital, teria como característica a participação ativa do Estado na criação das condições históri- 
cas para a acumulação do capital e para a apropriação privada do excedente. De acordo com Harvey, a acumulação por espoliação teria quatro características principais:

(i) a privatização e a mercadificação: uma das marcas do projeto neoliberal e da acumulação por espoliação seria a privatização e a mercadificação de ativos até então considerados públicos, com o objetivo de abrir à acumulação campos antes excluídos do cálculo da lucratividade. Nas palavras de Harvey, "todo tipo de utilidade pública (água, telecomunicações, transporte), de benefícios sociais (habitação social, educação, assistência à saúde, pensões), [...] foi privatizado em alguma medida por todo o mundo capitalista [...] a passagem de direitos de propriedade comum, obtidos ao longo de anos de dura luta de classes (o direito estatal à aposentadoria, ao bem-estar social, a um sistema nacional de saúde) ao domínio privado tem sido uma das egrégias políticas de espoliação, com freqüência imposta contrariando a ampla vontade da população. Todos esses processos equivalem à transferência de ativos do domínio público e popular aos domínios privados e de privilegio de classe" (Harvey, 2005, p.172-173) [sem grifo no original].

(ii) financialização: por financialização, Harvey descreve uma forte onda instaurada a partir dos anos 80, marcada por um estilo especulativo e predatório na gestão da riqueza. Por meio da criação de novos instrumentos de especulação, como os derivativos, este processo teria sido responsável pela produção de uma imensa riqueza para poucos a expensas de muitos, com a produção de bolhas especulativas, "operações fraudulentas com ações, esquemas Ponzi, a destruição planejada de ativos por meio da inflação, a dilapidação de ativos por meio de fusões e aquisições agressivas, a promoção de níveis de endividamento que reduziram populações inteiras à escravidão creditícia, para não falar das fraudes corporativas e da espoliação de ativos (o assalto aos fundos de pensão e sua dizimação pelo colapso do valor de títulos e ações e de corporações inteiras)" (Harvey, 2005, p.173-174).

(iii) administração e manipulação das crises: ao lado das bolhas especula- 
tivas, Harvey descreve também o processo de "lançar a rede da dívida" como recurso primordial da acumulação por espoliação. Nas palavras do autor, "a criação, a administração e a manipulação das crises no cenário mundial evoluíram para uma sofisticada arte de redistribuição deliberada de riqueza de países pobres para países ricos [...] Uma das principais funções das intervenções do Estado e das instituições internacionais é controlar as crises e desvalorizações de maneira que permitam a acumulação por espoliação sem desencadear um colapso geral ou uma revolta popular" (Harvey, 2005, p.175-176).

(iv) redistribuições via Estado: por fim, Harvey atribui ao Estado um papel especial sob o neoliberalismo - o papel de agente de políticas redistributivas, que reverte o fluxo típico das economias de bem-estar (redistribuição de cima para baixo). Nas palavras de Harvey, "ele o faz antes de tudo promovendo esquemas de privatização e cortes de gastos públicos que sustentam o salário social. Mesmo quando a privatização parece favorável às classes baixas, seus efeitos de longo prazo podem ser negativos. Por exemplo, numa primeira impressão, o programa thatcheriano de privatização da habitação social na Inglaterra pareceu uma benção para as classes baixas, cujos membros poderiam a partir de então passar do aluguel à casa própria a custos relativamente baixos, obter o controle de um valioso ativo e aumentar sua riqueza. Mas, uma vez feita a transferência, a especulação com moradias assumiu o controle, particularmente em áreas nobres, acabando por expulsar as populações de baixa renda, via propina ou pela força, para a periferia de Londres, transformando propriedades antes destinadas à moradia da classe trabalhadora em centros de intensa gentrificação" 2 (Harvey, 2005, p.176-177). Outros exemplos de redistribuição via Estado são a concessão de subsídios a famílias com maior poder aquisitivo e a política de desoneração dos impostos incidentes sobre atividades financeiras lideradas pelos grupos mais bem posicionados na sociedade, promovendo-se um redirecionamento da pressão tributária incidente sobre as classes mais abastadas em direção ao contribuinte de menor poder aquisitivo.

2 Sobre Londres e seu status atual de megacidade é interessante ver reportagem "Só para os muito ricos: bilioná-rios inflacionam o mercado imobiliário, comprando mansões por até $R \$ 207$ milhões" no Caderno Especial Grandes Reportagens - Megacidades, do Jornal O Estado de São Paulo, em 03 de agosto de 2008. 
A racionalidade das novas arquiteturas de financiamento imobiliário no Brasil reproduz o quadro descrito por David Harvey, em especial as possibilidades de manipulação do sistema de crédito a serviço da acumulação de capital e da redistribuição da riqueza e da renda aos grupos de maior poder aquisitivo. Neste sentido, uma grande lacuna nas análises dos sistemas de financiamento imobiliário é a dificuldade de compreendê-los a partir da sua sintonia com os padrões de acumulação expressos no sistema mundial. Superar esta lacuna exige analisar o Sistema de Financiamento Imobiliário (SFI) a partir dos pressupostos políticos implícitos na sua matriz teórica, nos documentos do Banco Mundial e nos primeiros resultados da sua aplicação no Brasil.

As novas arquiteturas de financiamento da habitação não se firmam, definitivamente, como sistemas de promoção de direitos sociais. Muito pelo contrario: reduzem o direito à moradia ao acesso privado a uma mercadoria livremente negociada no mercado. Neste sentido, expressam claramente aquela tendência à mercadificação, típica do regime de acumulação dos últimos trinta anos, e elegem o mercado como o grande protagonista na promoção das políticas do setor. Como bem notou Harvey, "a mercadificação presume a existência de direitos de propriedade sobre processos, coisas e relações sociais, supõe que se pode atribuir um preço a eles e negociá-los nos termos de um contrato legal. Há o pressuposto de que o mercado funciona como um guia apropriado - uma ética - para todas as ações humanas" (Harvey, 2005, p.178).

A redução do direito à moradia à simples garantia do acesso privado a uma mercadoria faz do crédito o principal instrumento na execução das políticas habitacionais, circunscrevendo a questão política à definição dos limites do subsídio estatal aos financiamentos tomados pelos mutuários. O cidadão beneficiário de um direito transforma-se em um cliente do sistema bancário, incluído ou excluído das modalidades de financiamento. O risco do financiamento, as garantias pessoais e reais oferecidas, o nome limpo na praça viram um problema de quem demanda a mercadoria. Como nota Harvey, pensando no desmonte das políticas de bem-estar da Europa e dos Estados Unidos, "um sistema de responsabilidade pessoal subs-titui as proteções sociais (pensões, assistência à saúde, proteção contra acidentes) que foram antes responsabilidades dos empregadores e do Estado. Os indivíduos compram produtos nos mercados, 
que passam a ser os novos fornecedores de proteções sociais. A segurança individual se torna assim uma questão de escolh a individual vinculada à capacidade de pagamento por produtos financeiros inseridos em mercados financeiros arriscados" (Harvey, 2005, p.181).

Outra marca da acumulação por espoliação que pode ser observada na estruturação da nova arquitetura do financiamento da habitação é a financialização. A expansão da base do financiamento do setor e a atração da liquidez antes canalizada para outros mercados exigem a formatação de novos instrumentos de crédito e a criação de mercados primários e secundários para a negociação dos novos produtos financeiros. A associação entre a crise dos mercados financeiros de 2008 e a expansão do crédito imobiliário nos Estados Unidos dá bem a medida deste processo. No Brasil, o processo de financialização, inspirado nos modelos do Banco Mundial, é defendido por muitos como a grande alternativa para a captação de recursos para o setor imobiliário, inclusive para o setor habitacional. Veja, por exemplo, os comentários de uma publicação veiculada por respeitada instituição de ensino, pesquisa e negócios:

é possivel observar que as operações de mercado vêm ganhando terreno no conjunto das modalidades de créditos disponíveis nos diversos países. Somou-se ao cenário econômico mais favorável um processo de liberalização e desregulamentação em muitos mercados nacionais, o que contribui, de forma decisiva, para amenizar as restrições sobre o crédito. Essas tendências favoráveis [...] atuam como elementos determinantes para uma boa precificação do risco nos empréstimos e para uma melhor classificação do crédito. Com isso, este último fica mais eficiente e pode ser mais bem alocado. Sensíveis melhoramentos na avaliação do risco dos empréstimos e na sua classificação trouxeram mais eficiência para as operações de crédito (FGV-Projetos, 2007, p.14).

Por fim, é inegável observar na arquitetura dos novos modelos de financiamento da habitação a quarta característica apontada por Harvey - a redistribuição via Estado. O modelo de financiamento, lastreado na captação de recursos pelos mercados de capitais, seja nos mercados primários, seja nos mercados secundários, não prescinde do fundo público, como pode parecer à primeira vista. Praticamente não há experiência no mundo, em especial na periferia do capitalismo, de uma capta- 
ção de recursos que não tenha contado com o apoio dos fundos estatais, seja pelo aporte direto de recursos orçamentários, seja pela concessão de garantias, seja pela concessão de isenções e vantagens tributárias que garantem competitividade aos fundos de investimento. O próprio Banco Mundial, sempre um militante do protagonismo do mercado, é um defensor da participação ativa do Estado na criação das condições efetivas para o desenvolvimento do financiamento imobiliário. Assim, mesmo os mais sofisticados sistemas de crédito tendem a depender do Estado para impulsionar a acumulação de capital, de modo que a apropriação privada da riqueza e da renda pelos agentes econômicos envolvidos nos sistemas ilustra com bastante propriedade o processo de redistribuição de recursos descrito por Harvey.

A acumulação por espoliação não pode, neste sentido, ser ignorada nas análises das novas arquiteturas do financiamento habitacional e imobiliário. Os estudos sobre o Sistema Financeiro da Habitação - SFH e do Sistema Financeiro Imobiliário - SFI têm de levar em conta a manifestação histórica deste processo para apreender os efeitos positivos e negativos da financeirização do crédito imobiliário e do crédito habitacional, por conseqüência. Como argumentado há pouco, o resultado da política habitacional, em um quadro permanente de acumulação por espoliação, não pode ser percebido somente pela efetividade social da produção de moradias, mas também por sua capacidade de construir um consenso em torno da efetivação de um ambiente institucional favorável à acumulação de capital pelos agentes privados.

\subsection{A crise de 2008 nos Estados Unidos - o crédito imobiliário no banco dos réus}

Em setembro de 2008, após sucessivos revezes e incontrolável processo de baixa, a bolsa de valores de Nova lorque apontava o que todos temiam - a maior crise econômica em décadas, provavelmente a maior crise desde 1929. Muitas explicações, muitas incertezas, e um primeiro responsável: o sistema de crédito imobiliário norte-americano, responsável pelo que muitos consideram o fato que deflagrou a crise - o estouro de uma bolha imobiliária. A crise ganhava um sobrenome e passa- 
va a ser discutida como a crise imobiliária americana ou a crise dos subprimes. Buscavam-se os responsáveis. Alguns sugeriam a prisão dos suspeitos de sempre - os tomadores do crédito, que irresponsavelmente teriam desencadeado a demanda por um crédito que jamais teriam condição de tomar ${ }^{3}$. Outros, a utilização desenfreada de uma fórmula matemática, como se o termômetro fosse o culpado pela febre ${ }^{4}$. No geral, havia percepção de que a especulação chegara a um nível intolerável, pondo em risco todo o sistema de crédito imobiliário nos Estados Unidos da América.

Compreender as origens da bolha imobiliária norte-americana, mais do que apontar os res-ponsáveis pela crise de 2008, permite-nos conhecer as entranhas do processo de financeirização ${ }^{5}$ do crédito imobiliário e verificar a real dimensão do vínculo entre a crise e a extensão da política de acesso à moradia. O fato da crise de 2008 ter sido desencadeada no mercado de hipotecas diz muito sobre este vínculo, mas não conta boa parte da história, fazendo-nos perguntar o que de fato teria gerado uma crise daquela proporção.

Como bem aponta Panitch e Konings (Panitch; Konings, 2009, p. 73), é difícil encontrar algum sentido para a crise sem compreender suas raízes domésticas, fundadas nas redes financeiras que há décadas subordinam os trabalhadores e a classe média americana a um regime de endividamento. Conforme os autores, "a era neoliberal não levou a uma completa deterioração dos padrões de vida da maioria das famílias de trabalhadores americanos: os altos níveis de consumo foram sustentados pelo acúmulo de dívidas familiares e pela intensificação do trabalho - muitas pessoas trabalhando durante mais horas, sob condições precárias, sujeitas à pressão dos compromissos financeiros" (Panitch; Konings, 2009, p. 74). Incentivados pelo governo, os norte-americanos se endividavam para financiar o seu alto nível de consumo, dando como

3 GREENSPAN, Alan. FED não tem culpa pela bolha imobiliária. Jornal Folha de S. Paulo, São Paulo, 10 de abril de 2008, Caderno Dinheiro.

4 CRUZ, Renato. A fórmula que destruiu Wall Street - instituições financeiras calculavam risco de hipotecas de um jeito que só funcionava com mercado em alta. Jornal O Estado de S. Paulo, São Paulo, 15 de março de 2009, Caderno Economia B11.

5 Harvey utiliza largamente o termo financialização. Em nota, o tradutor do seu livro sobre o neoliberalismo observa que, no Brasil, adota-se também o termo financeirização. Justifica, porém, o termo financialização por tratar-se de sujeição de toda a economia ao capital financeiro para fins especulativos de acumulação do capital e não para outros fins, criando o chamado capital fictício. Ver Harvey, Op. Cit. pp. 41-42, NT. Neste trabalho, preferimos o termo financeirização, mais divulgado como referência ao fenômeno descrito por François Chesnais, José Carlos Braga e pelo próprio David Harvey. 
garantia a hipoteca de seus imóveis. Todas as decisões financeiras pessoais eram baseadas na crença difundida de que a habitação era livre de riscos, o que proporcionava um aumento no valor da hipoteca sempre que houvesse necessidade de ampliação do crédito pessoal. O mais importante: estabeleceu-se um vínculo profundo entre o consumo das famílias americanas e o valor das propriedades que, "combinado ao fetiche da casa própria criava um espiral de mútua alimentação entre o crescimento da demanda do mercado e o valor crescente da habitação" (Panitch; Konings, 2009, p. 74).

Assim, a baixa taxa de juros (em torno de 1\% ao ano) incentivava o consumo desenfreado e incentivava o endividamento. Os empréstimos pessoais eram concedidos, na maioria das vezes, tendo o imóvel como garantia. Quanto mais crescia a demanda por crédito, mais aumentava o valor dos imóveis. Neste contexto, o preço crescente dos imóveis indicava uma ótima oportunidade de negócios, um investimento com excelentes perspectivas de valorização. A produção imobiliária destinava-se, como não podia deixar de ser, ao atendimento dos investidores, internos e externos, que apostavam na oscilação positiva dos imóveis para especular.

Os empréstimos pessoais, lastreados nas hipotecas, eram feitos por diversos agentes, especialmente por empresas de corretagem de crédito. A remuneração destes corretores era calculada em função da quantidade de crédito gerado e vendido. Assim, não havia compromisso, por parte destes agentes, com a qualidade do tomador do crédito, apenas com o volume de negócios que conseguiam viabilizar. O resultado, ao que tudo indica, foi a ocorrência de fraudes generalizadas na apuração da renda dos tomadores e, principalmente, na avaliação dos imóveis dados em garantia. Este foi um fator preponderante para o crescimento da quantidade e do rápido declínio da qualidade dos créditos classificados como subprime.

Bancos e investidores, ao adquirirem estes créditos ditos de baixa qualidade, compensavam o risco elevando as taxas de juros. Em grande parte, antecipavam seus ganhos alienando estes créditos em um mercado secundário, transferindo o risco da operação às empresas securitizadoras. Por sua vez, as empresas securitizadoras adquiriam créditos rentáveis, porém, de sem avaliação criteriosa do histórico de paga- 
mentos, do risco do tomador. Grandes investidores institucionais, principalmente fundos de pensão, viram neste mercado uma oportunidade única de melhorar a performance de suas carteiras. Estava estruturada uma cadeia operacional e financeira altamente arriscada, sujeita ao chamado efeito dominó, com possibilidade de 'contágio' de todos os elos que a integravam.

Segundo Delfim Neto, em artigo publicado no jornal Valor Econômico em 28 de agosto de 2007,

'subprime' é a hipoteca que garante um empréstimo feito a um comprador duvidoso elou, sem os cuidados de avaliação adequada dos seus rendimentos. Há suspeita de que gigantes financeiros criaram fundos que tomaram posição em papéis lastreados em 'subprimes', sem registrar seus 'riscos.' Com essa 'fantasia' contábil, transformam, magicamente, papéis duvidosos em AAA, sem registrá-los nos seus balanços [...]. A explicação fundamental para esse processo é o próprio aumento dos preços da casa própria estimulado pela expansão da demanda que o próprio sistema financeiro criava com novos e mais ágeis instrumentos de crédito. Tudo caminhava maravilhosamente, até que a delinqüência no pagamento das hipotecas 'subprime' começou a aumentar cobrando sua parte no descuido com a meIhor avaliação dos 'riscos.'

Em agosto de 2007, várias publicações explicavam a crise financeira mundial a partir dos'subprimes':

No mundo inteiro podemos ouvir ecos das dificuldades dos Estados Unidos [...] Começamos com os tomadores 'subprime.' Nos Estados Unidos essas pessoas, sem surpresa, são mais pobres (e pouco provavelmente brancos) que as que podem conseguir hipotecas a taxas inferiores, geralmente fixas. Sua tendência foi chegar tarde ao grande mercado ha-bitacional, quando os preços já eram estratosféricos. Muitos parecem ter sido encorajados a fazer empréstimos por corretores mais preocupados com as suas comissões que com a capacidade de seus clientes de pagar as dívidas. E os emprestadores que desembolsaram o dinheiro - dúzias dos quais tiveram que fechar as portas - subestimaram a taxa de ina-dimplência. De uma maneira geral, pode-se atribuir isso à relativa juventude do mercado subprime. De maneira menos generalizada, pode-se apontar o efeito da 'securitização' sobre os incentivos dos emprestadores: sabendo que os empréstimos podem ser reunidos, juntados e vendidos e depois picados, novamente empacotados e novamente ven- 
O editorial do The Economist mostra com clareza a natureza do atual mercado financeiro, em que todas as funções estão profundamente imbrincadas. Os bancos, de fato, não conseguiam determinar a dimensão dos prejuízos, pois a chamada 'diluição dos riscos' era de tal magnitude que não se sabia efetivamente o quanto das suas carteiras estava ligado ao mercado imobiliário e sujeito a qualquer tipo de contaminação. Nas palavras de um executivo responsável pela administração de uma carteira de investimentos,

surpreendentemente, os bancos ainda não foram capazes de determinar a dimensão completa de seus prejuízos com novos e complexos instrumentos de crédito. Agora eles estão sofrendo uma segunda rodada de prejuízos causados tanto pela alta nos índices de inadimplência quanto por uma ampla gama de empréstimos, à medida que os devedores sofrem o desgaste causado pela fraqueza da economia [...]. As dificuldades do setor financeiro estão estreitamente relacionadas à incerteza quanto às perspectivas econômicas e, acima de tudo, às expectativas do setor de habitação. Os preços das casas têm poderoso efeito sobre o consumo, por meio de seu impacto sobre o patrimônio e o acesso ao crédito. Eles também afetam as instituições financeiras ao influenciar o nível de inadimplência em hipotecas e o valor dos títulos lastreados por elas. [...] "A deflação nos preços dos ativos de habitação torna muito difícil estabilizar os balanços do sistema financeiro e também acentua os ventos contrários que a economia real está enfrentando", diz Mohamed El-Erian, co-presidente-executivo da administradora de fundos de investimento Pimco. ${ }^{8}$ [sem grifo no original]

A crise financeira levantou uma questão há muito discutida nos meios acadêmicos avessos à ortodoxia econômica - a necessidade de aumentar os níveis de regulação da economia, em especial, o nível de controle das instituições responsáveis pela concessão de crédito hipotecário. Conforme bem aponta Panitch e Konings, se uma razão singular tem predominado nas explicações da crise global, esta razão é a desregulação ("deregulation"): "A falta de supervisão estatal sobre o mercado financeiro é largamente criticada - não somente nas colunas de opinião dos jornais econômi-

7 THE TROUBLE with the housing market - editorial, The Economist, 22 de março de 2007. Disponível em $<$ http://www.economist.com>.

8 GUHA, Krishna. EUA se preparam para a 2a dose recessiva. Jornal Folha de São Paulo (matéria originalmente publicada no Jornal Financial Times), São Paulo, 20 de julho de 2008, caderno Dinheiro. 
cos como nos analistas da esquerda - por ter permitido a arriscada alavancagem das

instituições financeiras, baseadas em dívidas fracamente securitizadas, que acabaram levando à débacle atual" (Panitch; Konings, 2009, p. 67).

O diagnóstico da crise da regulação e a prescrição de um novo movimento regulatório, além do retorno das políticas econômicas keynesianas, iluminam uma questão que precede a crise provocada pela bolha imobiliária norte-americana. De fato, toda esta forma financeirizada do capitalismo mundial não surgiu com a inflação dos ativos imobiliários, nem com a especulação sobre os riscos das hipotecas subprimes. Há uma moldura institucional que é pressuposta na crise, que está presente nas raízes mais profundas do crash de 2008.

De acordo com Massonetto, o desenvolvimento do modo de produção capitalista em escala mundial é mediado por padrões regulatórios que refletem os padrões de acumulação e os padrões de gestão sistêmica do sistema mundial. Neste sentido, nas últimas décadas, é possível divisar: um padrão regulatório baseado na flexibilidade, na tutela estatal dos processos de capitalização financeira e no deslocamento das decisões financeiras para fora do Estado Nacional (Massonetto, 2009, p. 4).

E mais,

o fundo público, cuja liquidez garantira a expansão material do sistema mundial com promoção de bem-estar social, passou a garantir a renda financeira do capital, deslocando a matriz do Direito Financeiro [e da regulação] para os processos de capitalização. Neste sentido, a configuração de um novo padrão sistêmico de riqueza conferiu uma função peculiar ao Direito Financeiro [e à regulação]: a redução dos riscos inerentes à lógica financeira, garantindo, por meio de seus instrumentos, a liquidez exigida pelo mercado e, acima de tudo, assegurando a valorização patrimonial privada, por meio da sanção de ganhos financeiros (Massonetto, 2006, p. 95).

Este novo padrão regulatório, que permitiu acomodar as inovações financeiras que redundaram na crise de 2008, é um padrão bastante distinto do padrão regulatório do período anterior, baseado em uma participação ativa do Estado na estabilização do sistema e na garantia da expansão material do capitalismo. Essa participação, segundo Belluzzo, era destinada a não permitir que as atividades econômicas flutu- 
assem em níveis que pudessem ser danosos para o seu desenvolvimento. O Estado

exercia então uma função regulatória dos mercados, procurando reduzir a

influência dos condicionantes externos sobre as políticas macroeconômicas domésticas. Os controles de capitais eram prática corrente e assim as políticas monetárias e os sistemas financeiros nacionais estavam voltados para a sustentação de taxas elevadas de crescimento econômico. Comandados por políticas monetárias acomodatícias, os sistemas financeiros - incluídos os bancos centrais - funcionavam como redutores de incertezas para o setor privado, que, por sua vez, sustentava elevadas taxas de investimento. O círculo virtuoso entre gasto público, oferta de crédito barato, investimento privado e estabilidade financeira foi a marca registrada da economia da demanda efetiva. [...] Era a época de ouro do keynesianismo, e essas políticas tinham o propósito declarado de estimular o acesso à riqueza através do crédito dirigido à acumulação produtiva, com o desiderato de manter o pleno emprego, elevando, em termos reais, os salários e demais remunerações do trabalho. A regulamentação financeira foi a norma em todos os países. (Belluzo, 1999, p.100).

Com o acordo de Bretton Woods, assinado no segundo pós-guerra, e que continha as premissas para o desenvolvimento com forte participação do estado, as economias européias e o Japão lograram se recuperar de forma espetacular. Esse crescimento ampliou a riqueza mundial e fez aumentar o volume de dólares em circulação na economia.

Segundo Chesnais, a acumulação industrial da idade de ouro fez com que famílias com melhores disponibilidades financeiras começassem "a investir suas rendas excedentes líquidas em títulos de seguro de vida" (Chesnais, 2005, p.37). Esses e outros recursos líquidos oriundos de excedentes acumulados nas famílias e nas empresas no segundo pós-guerra agora procuravam se valorizar em outros investimentos, visto que os investimentos industriais pareciam não mais prover as taxas de juros que ofereciam antes, durante a década de 50.

A Inglaterra criou, então, na city de Londres, uma espécie de offshore, um mercado interbancário de capitais líquidos, conhecido como mercado de eurodólares. Lucros de empresas não reinvestidos na produção e também não repatriados pelas multinacionais americanas alimentavam essa praça, constituindo o que Chesnais 
vai apontar como a primeira base de operação internacional do capital portador de juros (Chesnais, 2005, p. 38).

A próxima etapa, no desenvolvimento histórico do padrão regulatório da expansão financeira do modo de produção capitalista, ficou marcada pelo choque do petróleo, isto é, pela inserção nessa ciranda de "elevadas somas resultantes do aumento temporário do preço do petróleo, aplicadas em Londres pelos potentados do golfo pérsico" (Chesnais, 2005, p. 39). Esses recursos foram a base de empréstimos para países do terceiro mundo, que dessa forma alavancaram sua dívida externa. De acordo com Belluzzo, esse "circuito financeiro internacionalizado e operado pelos grandes bancos comerciais - à margem de qualquer regulamentação ou supervisão dos bancos centrais - acentuou sua tendência à superexpansão do crédito concedido a empresas, bancos e governos, alimentando, sobretudo um forte endividamento da periferia" (Belluzzo, 1999, p. 102).

As dívidas dos países periféricos cresciam quase que exponencialmente e os juros absorviam parcelas crescentes do orçamento estatal e de suas reservas, forçando os devedores a tomarem novos empréstimos para honrar o serviço da dívida. Estes novos empréstimos, destinados ao serviço da dívida, submetiam os agentes endividados as taxas de juros de ocasião, fundamentais para a rolagem e ampliação de suas dívidas.

É nesse contexto que, em 1979, o governo americano resolve aumentar as taxas de juros a um padrão sem precedentes, disparando a dívida dos países subdesenvolvidos e mos-trando para todo o mundo que o dólar ainda era a moeda forte. De acordo com Belluzzo, na obra já citada, na prática, a ampliação dos mercados de dívida pública constituiu a base sobre a qual se assentou o desenvolvimento do processo de securitização. Isto não apenas porque cresceu a participação dos títulos americanos na formação da riqueza financeira demanda pelos agentes privados americanos e de outros países, mas também porque os papéis dos governos dos Estados Unidos eram ativos dotados de grande liquidez.

Assim, "créditos desvalorizados dos países em desenvolvimento foram sendo substituídos por dívida emitida pelo Tesouro Nacional dos Estados Unidos. [...] Foi nesse ambiente 
de reimposição da supremacia do dólar e de desestruturação do sistema monetário in-

ternacional que ocorreu 'a grande fuga para a frente,', consubstanciada no aparecimento dos novos processos de globalização, desregulamentação e securitização" (Belluzzo, 1999, p. 104).

Foi neste contexto que se deu o crescimento veloz da participação das formas financeiras de apropriação de riqueza. Nos países desenvolvidos, as classes médias passaram a investir em títulos e ações, diretamente ou por meio de fundos de investimento ou de fundos de pensão. "O patrimônio típico de uma família de renda média passou a incluir ativos financeiros em proporção crescente, além dos imóveis e bens duráveis. [Assim] a 'acumulação' de ativos financeiros ganhou na maioria dos casos status permanente na gestão da riqueza capitalista." (Belluzzo, 1999, p. 105).

Por fim, "essa impressionante escalada do volume de riqueza financeira [...] suplantou de longe o crescimento da produção e da acumulação de ativos fixos. [Como conseqüência,] a 'financeirização' e a correspondente valorização fictícia da riqueza, como nunca, vêm subordinando a dinâmica da economia" (Belluzzo, 1999, p. 105;115).

De onde conclui Belluzzo que

o capitalismo é o regime de produção em que a riqueza acumulada sob a forma monetária está sempre disposta a dobrar-se sobre si mesma, na busca da autoreprodução. D-D' e não D-M-D'é o processo em estado puro, adequado a seu conceito, livre dos incômodos e empecilhos de suas formas materiais particulares. Não se trata de uma deformação, mas do aperfeiçoamento de sua substância, na medida em que o dinheiro é o suposto e o resultado do processo de acumulação de riqueza no capitalismo. É este processo fantasmagórico de auto-reprodução que o capital está realizando sob os nossos olhos nos mercados financeiros contemporâneos ${ }^{9}$. (Belluzzo, 1999, p. 115-116)

9 É importante salientar que essa passagem do D-M-D' para o D-D'suscita importantes debates sobre a relação entre a base produtiva e a esfera financeira da economia. Pode-se questionar, por exemplo, se o próprio crash das bolsas de valores, ocorrido no mundo todo por conta das bolhas especulativas, não representaria um limite das possibilidades de descolamento da esfera financeira da base produtiva real. Como foi mencionado algumas páginas atrás, verifica-se no contexto da financeirização um aumento das horas de trabalho na economia global. Dessa forma, o debate sobre uma massa crescente de valor sendo produzida e apropriada em algum lugar (ainda que de forma menos visível), por trás da valorização que aparece como financeira e, por outro lado, a fantasmagoria de um processo que 'produz' dinheiro a partir do dinheiro, é relevante do ponto de vista dos fundamentos da própria existência do capitalismo enquanto sistema econômico, que, no entanto, foge ao escopo dessa tese. 
no primeiro trimestre de 2004 (depois do estouro da bolh a dos anos 90), o valor dos ativos financeiros detidos pelas famílias americanas - ações, cotas de fundos, títulos de dívida públicos e privados) era de US\$34,8 trilhões contra US\$20,1 trilhões em ativos tangíveis (casa própria, bens duráveis). [...] Observadas do ponto de vista das instituições e dos ins-trumentos financeiros, estas transformações na riqueza espelham a maior importância da finança direta e 'securitizada' em relação ao crédito bancário. [...] Esta mudança engendrou a 'securitização' de créditos e facilitou o envolvimento dos bancos com o financiamento de posições nos mercados de capitais e em operações 'fora do balanço' que envolvem derivativos (Tavares; Belluzzo, 2004, p. 127).

No Brasil, a transição do padrão regulatório pós-Bretton Woods para o padrão regulatório da expansão financeira do capitalismo também é perceptível.

Essa desarticulação entre grupos industriais e financeiros teve duas implicações importantes para a configuração patrimonial da economia brasileira nos anos posteriores. Em primeiro lugar, levou a um crescimento significativo dos conglomerados financeiros, cujo endividamento externo teve, como contrapartida, o crescimento da dívida pública interna, fonte dos lucros bancários na 'ciranda financeira' do open-market. Em segundo, levou, após a crise da dívida externa, à revisão das restrições às participações acionárias cruzadas entre bancos e indústria, mas já em um contexto de perda de dinamismo do investimento privado, configurando por isso, para os bancos privados, mais uma oportunidade de diversificação de risco para suas carteiras de títulos (Miranda; Tavares, 1999, p. 335)

A constituição de holdings, a criação ou compra de financeiras e bancos pelos principais grupos industriais nacionais originários constituíram base importante de suas condutas patrimoniais defensivas imperantes na década de 80. Uma economia altamente inflacionária, com moeda indexada e com um sistema financeiro sofisticado para operações de curtíssimo prazo, mas inoperante para o financiamento de longo prazo, e sofrendo estagnação de seu mercado interno, tende a moldar estratégias microeconômicas de caráter rentista. Em tais estratégias, o principal objetivo do investimento era diluir o risco e elevar as margens de lucro financeiro mediante a ampliação e a diversificação das carteiras dos grupos. Conseqüentemente, a diversificação deu-se principalmente em função da busca de ativos seguros ou de elevada 
liquidez, visando a proteção patrimonial dos grupos e a financeirização da riqueza

(Miranda; Tavares, 1999).

Belluzzo atenta para a característica essencial do capital portador de juros, fundamental para compreender o processo de securitização:

na lei geral da acumulação capitalista estão estruturalmente implícitas as necessidades de concentração e centralização dos capitais, comandada através da ampliação e da autonomização crescentes do capital a juros, ou seja, com o predomínio cada vez maior do sistema de crédito sobre as órbitas mercantil e produtiva. O capital a juros nasce, portanto, da necessidade de perpétua expansão e valorização do capital para além dos li-mites de seu processo mais geral e elementar de circulação e reprodução. Para revolucionar periodicamente a base técnica, submeter massas crescentes de força de trabalho a seu domínio, criar novos mercados, o capital precisa existir permanentemente de forma 'Iivre' e líquida e, ao mesmo tempo, crescentemente centralizada. Apenas dessa maneira pode fluir sem obstáculos para colher novas oportunidades de lucro. [...] Na verdade, o que distingue essa forma de capital financeiro das que a precederam historicamente é o caráter universal e permanente dos processos especulativos e de criação contábil de capital fictício [...]. A natureza intrinsecamente especulativa da gestão empresarial, nessa modalidade de 'capitalismo moderno', traduz-se pela importância crescente das práticas destinadas a ampliar 'ficticiamente' o valor do capital existente, tornando necessária a constituição de um enorme e complexo aparato financeiro. Segundo Hobson [...] se os ativos tangíveis podem ser avaliados pelo seu custo de produção ou reposição, aqueles de natureza não-tangível só podem sê-lo através de sua capacidade líquida de ganho. Esta, por sua vez, só pode ser estimada como o valor capitalizado da totalidade dos rendimentos futuros esperados, menos o custo de reposição dos ativos tangíveis. É aqui, neste último elemento (ativos não tangíveis), que reside a elasticidade do capital, comumente utilizada pela 'classe financeira' para ampliar a capitalização para além dos limites da capacidade 'real' de valorização. Dessa forma, a capacidade putativa de ganho de uma grande companhia, independentemente de como seja financiada, repousa fundamentalmente no controle dos mercados, na força de suas armas de concorrência, e é, portanto, mesmo amparada em métodos avançados de produção, altamente especulativa em seu valor presente (Belluzzo, 1999, p. 88;90-91).

Dessa forma, ao abrirem seu capital na bolsa de valores utilizando o Valor Geral de Vendas (VGV) de um determinado empreendimento como um ativo, as empresas 
imobiliárias participam dessa ciranda alimentando a especulação de seus papeis e

utilizando a cidade como fonte e objeto de sua atividade. Por essa lógica, já sabendo que determinado empreendimento terá seus créditos - oriundos ou do aluguel de seus espaços ou ainda do retorno de financiamentos - transformado em recebíveis imobiliários cujos papeis circularão na esfera dos ativos não tangíveis, o que era apenas um negócio, uma atividade produtiva dita tradicional, vira então a parte visível, tangível de uma valorização do capital financeiro.

Um desdobramento importante desse processo é o papel do governo e das políticas públicas no capitalismo contemporâneo. O que se apresenta como conseqüência importante para quem estuda e se debruça sobre políticas publicas é o quanto esse imperativo da riqueza financeirizada impacta nos orçamentos e no manejo de uma política governamental. Há um déficit publico que é constantemente alimentado pelas finanças, o que diminui sobremaneira o uso dos recursos públicos no desenvolvimento do país.

Pode-se afirmar que o estado de bem estar, que nunca existiu no Brasil da forma clássica, assenta-se na produção, na expansão material e que implicava a conversão de capital monetário em mercadorias, bens, serviços, enfim, havia a preponderância dos processos de elevação de renda na acumulação. Atualmente, no entanto, o que se verifica é que"ao estado, não basta mais assegurar a expansão do capital em seu território [...]. É necessário reduzir o risco da expansão financeiro sob sua jurisdição, além de garantir a valorização da riqueza privada. [...] o padrão normativo da expansão financeira [...] é marcado, na forma, pela flexibilidade, e, no conteúdo, pela tutela jurídica da renda financeira do capital" (Massonetto, 2006, p.104).

Dessa forma, se antes o orçamento público poderia ser utilizado para a inserção do país em um outro patamar de desenvolvimento, atualmente,

o orçamento público deve estar voltado para a garantia do investimento privado, para a garantia do capital privado, em detrimento dos direitos sociais e serviços públicos voltados para a população mais desfavorecida. Assim, nesta etapa, o direito financeiro, na organização do espaço políticoeconômico da acumulação, passa a servir a uma nova função do Estado 
- a tutela jurídica da renda do capital e da sanção de ganhos financeiros

privados, a partir da alocação de garantias estatais ao processo sistêmico de acumulação liderado pelo capital financeiro (Massonetto, 2006, p. 69).

\subsection{A indistinção entre financiamento imobiliário e financiamento habitacional}

Ao se analisar as arquiteturas de financiamento da habitação no Brasil deparamonos com certa imprecisão na qualificação dos sistemas financeiros. A origem do equívoco é o uso indistinto que é feito entre os termos "imobiliário" e "habitacional" na imprensa e em documentos setoriais. Ainda que os sistemas financeiros atualmente existentes, o Sistema Financeiro de Habitação, SFH, e o Sistema Financeiro Imobiliário, SFI, possuam denominações distintas, a confusão costuma ser freqüente. Aparentemente, o erro poderia ser corrigido sem maiores problemas, se não fosse a conveniência da manutenção desta imprecisão.

Na medida em que a crise mundial vinculou o crédito imobiliário (e habitacional) a ou-tros mercados de crédito, como o crédito ao consumidor, é fundamental compreender as especificidades de cada negócio a partir de suas características particulares, e desvendar os vínculos que aproximam instrumentos tão distintos. A propagação da suposta excelência do sistema americano de captação de recursos no mercado, base da arquitetura de financiamento imobiliário e de habitação dos Estados Unidos, obscureceu a distinção entre os modelos, como se as funções de cada sistema não incidissem na sua estruturação. De acordo com o modelo na vitrine, o que importava era a liberdade dos agentes e o protagonismo do mercado na captação dos recursos, independente da sua finalidade (imobiliária, em geral, ou habitacional). Seria importante a condução de uma pesquisa empírica ainda a ser elaborada que mostrasse a distinção dos diversos agentes que compõem esse sistema (proprietários, incorporadores, construtores, agentes de crédito, setores do estado), compreender o papel desempenhado por cada um deles e o tipo de apro- 
priação consumado ${ }^{10}$. No entanto, já a análise do discurso aponta questões importantes que podem auxiliar na compreensão dos recentes desdobramentos e resultados do SFH e do SFI.

Basicamente, a expressão "mercado imobiliário" diz respeito a toda transação que envolva um bem imóvel, referindo-se à propriedade da terra e às edificações incorporadas, com seus diversos usos, e excluindo a infra-estrutura destinada a dar suporte ao seu funcionamento. Por exemplo, engloba a edificação de um shopping center, a terra em que ele se incorpora, mas não as estradas que lhe dão acesso, nem as obras de saneamento básico que o viabilizam. "Imobiliário", neste sentido, compreende tudo o que é relativo a um imóvel, seja ele destinado à moradia, seja ele destinado a um uso diverso, como uma escola, uma fazenda ou um centro comercial.

Nos últimos anos, com a internacionalização dos mercados e com a massificação do sistema norte-americano pelas escolas de negócio, o termo "real estate" tem ocupado um lugar de destaque na descrição dos negócios imobiliários. Na origem, a expressão, que não tem uma tradução exata para o português, referia-se à propriedade e aos bens incorporados. Posteriormente, passou a descrever uma atividade negocial. Assim, o termo "real estate" significa atualmente tanto o bem imóvel como a atividade imobiliária. De acordo com Downes e Goodman, "real estate" é um "pedaço de terra e todas as propriedades físicas relacionadas a ele, incluindo casas, cercas, paisagismo e todos os direitos sobre o espaço aéreo e o subsolo. Ativos não associados diretamente com a terra são considerados propriedade pessoal (móveis, veículos, seguros)"11. Já de acordo com Friedman, Harris e Lindeman, "no direito, é a terra e tudo mais ou menos incorporado nela. Propriedade que vai do centro da terra (subsolo) até o céu (above to the heavens)"12. Já no âmbito de negócios, de acordo com o mesmo

10 Devo essa importante reflexão à urbanista Mariana Fix, em dialógo sobre as conseqüências da distinção entre os termos 'imobiliário' e 'habitacional'.

11 Downes, John. Dictionary of Finance and Investment Terms. Barrons, 2003 e Friedman, Jack P. Dictionary of Real Estate Terms. Barrons, 2004.

12 O conceito de propriedade abrangendo o subsolo e o espaço aéreo é um conceito oriundo do direito romano (quem é dono do solo é também dono até o céu e até o inferno), recebido pelo Código de Napoleão, pelo BGB (Código Alemão) e pelo Código brasileiro de 1916. Ainda que obviamente tenha havido mudanças relativas ao conceito, chama a atenção o seu caráter sagrado, vinculando o solo ao inferno e ao céu (heaven, que em inglês tem uma conotação sagrada). Ver PEREIRA, Caio Mário da Silva. Instituições de Direito Civil - Volume IV - Direitos Reais. Rio de Janeiro: Forense, 2009. 
dicionário, "real estate" pode ser traduzido como "as atividades atinentes à posse, à propriedade e à transferência de uso da propriedade" 13 .

Nos Estados Unidos, o "real estate" como negócio tem uma longa tradição, desde suas famosas "savings and loans companies" do início do século XX. No entanto, a atividade de real estate adquiriu outra conotação após a desregulamentação dos mercados financeiros iniciada na década de 70. Desde então, "real estate" traduz um negócio financeiro, completamente imerso no mercado de capitais e dedicado à promoção de ganhos específicos, da incorporação e administração de imóveis ao agenciamento de crédito e administração de garantias. Neste sentido, podemos citar várias atividades especializadas que se vinculam ao negócio do "real estate": contadores (accountants), avaliadores de imóveis (appraisers), procuradores (attorneys), corretores imobiliários (brokers); especialistas (counselors); agentes governamentais (government regulators), corretores hipotecários (mortgage brokers), credores hipotecários (mortgage lenders), vendedores (salespersons); prospectadores (surveyors); securitizadoras (title companies) ${ }^{14}$.

Nesta perspectiva, contaminado pelas múltiplas acepções de "real estate", o negócio imobiliário passou a representar muito mais do que simplesmente a transação de bens imóveis. Passou a configurar um novo modo de ser da reprodução do capital imobiliário, demandando a estruturação de um sistema de crédito a serviço da valorização imobiliária e da acumulação financeira do capital. Assim, imobiliário não é mais apenas um gênero de negócio, dentre os quais se inclui o negócio da habitação. É uma nova forma de circulação e apropriação da riqueza. Nestas idas e vindas, o termo imobiliário, ligado à arquitetura de financiamento de certos bens, não veicula mais somente uma tipologia dos bens financiados, designando um gênero do qual a habitação é uma espécie, mas sim um modo de ser específico da acumulação da riqueza no setor.

Já o conceito de "habitação", como fração do negócio imobiliário, compreende toda edificação destinada ao uso residencial e que possa ser transacionada no merca-

13 Downes, J. e Friedman, J.P., op. cit.

14 Friedman, Jack P. Dictionary of Real Estate Terms. Barrons, 2004, termo Real Estate. 
do. A possibilidade de transação do imóvel residencial no mercado é crucial para o mercado de crédito, já que as operações de financiamento costumam utilizar o próprio bem financiado como garantia. Visto que a propriedade é o principal lastro de uma política de captação de recursos, como a emissão de títulos lastreados por hipotecas, há uma enorme dificuldade de combinar os modelos de mercado com certas políticas de regularização fundiária urbana calcadas em instrumentos distintos do direito de propriedade, como a concessão de direito real de uso ou de uso especial para fins de moradia. Quanto menor o reconhecimento pelo mercado dos títulos oferecidos como garantia, menor a probabilidade da liberação do crédito ${ }^{15}$. De modo que quanto maior à informalidade, maior o risco da operação e menor a possibilidade de acesso ao crédito. Enfim, propriedade é garantia e garantia é a base do sistema de crédito operado pelo mercado.

Ainda que se deva compreender o conceito de habitação como moradia digna, que engloba serviços, infra-estrutura, acessibilidade e transporte, segurança jurídica da posse, habitabilidade, custos acessíveis ${ }^{16}$, reforçando o aspecto urbano e de inclusão social contido no direito à moradia consignado na Constituição Federal, o termo "habitacional"' no financiamento tende a considerar apenas e tão somente o bem físico da 'casa'. Talvez seja por isso que a quantificação do número de financiamentos concedidos no âmbito de determinada política habitacional seja um poderoso indicador de atendimento dessa política, ainda que outros fatores devam ser considerados para indicar o sucesso de uma política habitacional.

O padrão de financiamento da política habitacional brasileira pós 1964 esteve centrado no crédito lastreado na captação de poupança, tanto voluntária quanto compulsória e muito pouco no repasse de recursos orçamentários de origem fiscal. A constituição do SFH, nascido de uma conjuntura de intervenção do estado na

\footnotetext{
15 Informações obtidas junto a especialistas convidados para reuniões realizadas pelo Grupo de Estudos de Mercado Imobiliário realizadas no LABHAB/FAUUSP no ano de 2008.

16 A conceituação de moradia digna remonta à década de 80 e à luta política instaurada na Assembléia Nacional Constituinte por acadêmicos e movimentos sociais, entre outros atores, para inserir na nova Constituição Federal essa acepção da moradia como a que deveria ser considerada na Constituição como um direito social e fundamental do cidadão que deveria receber a proteção constitucional. Para maior detalhamento ver Plano Nacional de Habitação, PLANHAB, disponível em < http://www.cidades.gov.br/secretarias-nacionais/secretaria-de-habitacao/planhab/produtos/produtos>, e SAULE Jr., Nelson. A Proteção Jurídica da Moradia nos Assentamentos Irregulares. São Paulo: Sérgio Antonio Fabris Editor, 2004.
} 
economia, regulação de mercados e direcionamento de recursos onerosos a partir

de critérios políticos é bastante distinta da formatação do SFI, criado em 1997 em pleno período de consecução do ajuste neoliberal no Brasil, que pressupõe a livre negociação entre as partes, limitando-se o estado a resolver as chamadas 'falhas de mercado'

O que requer atenção é o fato de que esse capital fictício que domina as finanças mundiais atuais está cada vez mais entranhado no mundo 'real' da cidade. Essa forma de produção do ambiente construído ${ }^{17}$ está ganhando cada vez mais força no desenho de um sistema de financiamento habitacional e de infra-estrutura no Brasil, que seriam inicialmente destinados a dar conta das imensas necessidades do país. A formatação e implantação do SFI parecem reforçar esse entendimento.

O SFI foi criado como uma possibilidade real de estabelecer um mercado importante no país para o financiamento a empreendimentos imobiliários. A 'ausência do sistema nervoso' para 'deslanchar' o setor imobiliário no Brasil, como aponta Fix ${ }^{18} \mathrm{em}$ relação ao sistema de crédito para a produção de torres de escritório, um dos principais tipos de empreendimentos imobiliários pelo volume de produção e valores envolvidos, demonstra a importância dada pelo setor imobiliário na formatação de um sistema financeiro próprio em meados da década de 90. Toda a argumentação de que falta um sistema de crédito destinado ao setor imobiliário, de que o setor será alavancado caso esse sistema funcione, vem ao encontro da edição da lei do SFI.

Apesar do foco mais expressivo no financiamento de imóveis não-residenciais, a habitação acabou virando um excelente pretexto para o discurso da alocação de recursos do SFH na promoção de produtos imobiliários em geral, por meio do ambiente financeiro do SFI. Na ocasião da criação deste sistema, não faltaram os que

17 Conceito trabalhado por Harvey: "sob essa expressão incluo a totalidade das estruturas físicas - casas, ruas, fábricas, escritórios, sistemas de esgotos, parques, equipamentos culturais e educacionais etc [...] esse processo de criação do espaço é cheio de contradições e tensões e que as relações de classes nas sociedades capitalistas geram inevitavelmente fortes conflitos e correntes cruzadas" HARVEY, David. O trabalho, o capital e o conflito de classes em torno do ambiente construído nas sociedades capitalistas avançadas. Espaço \& Debates, São Paulo, n. 06, ano II, 1982, p. 06-35. Os urbanistas Mariana Fix e Joao S. W. Ferreira trabalham esse conceito ao tratar da constituição de grandes empreendimentos imobiliários, do circuito financeiro do capital e do mito da cidade global. Ver FIX, Mariana. São Paulo Cidade Global. Boitempo, 2007. FERREIRA, João S. W. São Paulo: O Mito da Cidade Global. São Paulo, 2003. Tese (Doutorado) - Faculdade de Arquitetura e Urbanismo, Universidade de São Paulo. 
criticassem o SFH como ultrapassado, defendendo a sua substituição para que fi-

nalmente a questão habitacional fosse resolvida. Mesmo que o SFH continue produzindo seus resultados, ainda resistem os que vêem no modelo do SFI a grande oportunidade de combate ao déficit de moradias no Brasil.

O SFI não substituiu o SFH. O SFI também não se limitou a ampliar as condições para o financiamento de imóveis não residenciais, não contemplados no modelo anterior. No final das contas, o SFI tencionou criar um ambiente de negócios capaz de atender todo tipo de demanda imobiliária, disseminando uma nova forma de riqueza imobiliária. À sua forma, o SFI reforça a era do "real estate" como "business" no Brasil.

No entanto, ainda que os números recentes do SFH demonstrem que ultrapassado e falido são adjetivos que não caracterizam sua operacionalização, é sabido que o equacionamento da questão habitacional não depende unicamente do crédito. A questão fundiária é o outro ponto fundamental para o equacionamento do problema da habitação. Nossa tese, no entanto, não tratará da questão da terra, ainda que ela seja de importância seminal para o urbano e para a própria compreensão da sociedade brasileira. Deteremo-nos somente na questão do crédito, procurando entender sua evolução institucional nos últimos 40 anos e suas tendências recentes. 
CAPÍTULO 2 Estado e Mercado na Promoção da Política Habitacional: quadro histórico da evolução do crédito habitacional e imobiliário no Brasil 
O Sistema Financeiro de Habitação, o Sistema Brasileiro de Poupança e Empréstimo e o Fundo de Garantia do Tempo de Serviço foram marcos fundamentais para o desenvolvimento do crédito habitacional e imobiliário no Brasil. A lei que criou o Banco Nacional da Habitação (BNH), lei 4.380, de 21 de agosto de 1964, instituiu também o Sistema Financeiro de Habitação (SFH), com a grande inovação da correção monetária nos contratos imobiliários, além das Sociedades de Crédito Imobiliário (SCl), as Letras Imobiliárias (LI) e o Serviço Federal de Habitação e Urbanismo (SERFHAU). O BNH era o órgão central, normativo e financiador do SFH e do Sistema Financeiro de Saneamento (SFS)'

No mesmo ano foi editada a Lei 4.591, de 16 de dezembro de 1964, conhecida como a Lei das Incorporações Imobiliárias, considerada também fundamental para a estruturação de um mercado imobiliário e habitacional, regulamentando e disciplinando a constituição de condomínios, forma cada vez mais utilizada na crescente ocupação dos espaços urbanos². Em 1966 foi criado o Fundo de Garantia do Tempo de Serviço (FGTS), por meio da lei 5.107 e, em 1968, houve a regulamentação da caderneta de poupança, por meio de Resolução do Conselho Diretor do BNH. Rapidamente, ambos os recursos, oriundos do FGTS e da caderneta de poupança, tornaram-se os principais instrumentos de funding para o crédito habitacional e imobiliário no país.

Para os objetivos dessa tese serão destacadas brevemente a constituição, operação e de-sempenho do FGTS e do Sistema Brasileiro de Poupança e Empréstimo (SBPE), e não o desempenho e o histórico do BNH, ainda que em muitos momentos a análise seja impossível de ser dissociada. Também não nos debruçaremos sobre a análise dos recursos não onerosos destinados à execução de política habitacional (Orçamento Geral da União) visto que o propósito da tese não é analisar a política

1 Lei no. 4.380, de 21 de agosto de 1964. Institui a correção monetária nos contratos imobiliários de interesse social, o sistema financeiro para aquisição da casa própria, cria o Banco Nacional da Habitação (BNH), e Sociedades de Crédito Imobiliário, as Letras Imobiliárias, o Serviço Federal de Habitação e Urbanismo e dá outras providências.

2 A Lei 4.591, de 16 de dezembro de 1964, estabelece as bases para a organização da propriedade imobiliária sob a forma de condomínio: "Art. 10. As edificações ou conjuntos de edificações, de um ou mais pavimentos, construídos sob a forma de unidades isoladas entre si, destinadas a fins residenciais ou não-residenciais, poderão ser alienados, no todo ou em parte, objetivamente considerados, e constituirá, cada unidade, propriedade autônoma sujeita às limitações desta Lei". 
desenvolvida no país após a criação do BNH, mas sim analisar os sistemas de finan-

ciamento habitacional e imobiliário. É bom salientar que, no caso brasileiro, a política habitacional é executada tendo como fundo financeiro uma série de recursos, onerosos e não onerosos, provenientes de diversas fontes. Uma análise completa da execução da política habitacional requereria, portanto uma análise do desempenho de todos esses fundos.

\subsection{SFH, SBPE e FGTS até o Plano Real}

Até pela distância histórico-temporal, tende-se a considerar o período de vigência do BNH como um período homogêneo, constituído por uma única lógica, explicitando-se e analisando-se principalmente os grandes números gerados pelo $\mathrm{BNH}$ e as principais causas de sua extinção. As distensões e os conflitos internos ficam subsumidos dentro do quadro maior de sua produtividade numérica. No entanto, uma análise, ainda que expedita, sobre os principais períodos do BNH e do SFH nos auxilia na compreensão da atual estrutura do SFH, suas mudanças institucionais e as principais características do funcionamento e da estrutura de um sistema de financiamento habitacional e imobiliário de grandes proporções. Vários autores se debruçaram sobre esse tema, analisando as condições políticas e sociais dos primeiros anos do BNH, procurando identificar as motivações do regime militar e as principais características do sistema ${ }^{3}$.

3 Trabalhos seminais sobre o assunto incorporam a dimensão política, social e econômica do BNH, procurando analisar também as linhas programáticas e os resultados obtidos. Ver ANDRADE, Luis Aureliano. Política urbana no Brasil: o paradigma, a organização e a política. Revista Estudos CEBRAP. v.18, p.117-148, out./ dez., 1976; ARRETCHE, Marta. Intervenção do Estado e setor privado: o modelo brasileiro de política habitacional. Revista Espaço e Debates, São Paulo, v. 31, p. 21-36, 1990; AZEVEDO, Sérgio de. Vinte e dois anos de habitação popular (1964-1986): criação, trajetória e extinção do BNH. Revista de Administração Pública, Rio de Janeiro, v. 4, n.22, p.107-119, out./dez., 1988; BOLLAFI, Gabriel. Aspectos socioeconômicos do Plano Nacional de Habitação. Tese (Doutorado), Faculdade de Arquitetura e Urbanismo, Universidade de São Paulo. São Paulo, 1972; MARICATO, Ermínia. Política habitacional no regime militar. Petrópolis: Vozes, 1987; VALLADARES, Lícia (org.). Repensando a Habitação no Brasil. Rio de Janeiro: IUPERJ/Zahar, 1982; AZEVEDO, Sérgio; ANDRADE, Luís Aureliano, G. Habitação e Poder, da Fundação da Casa Popular ao BNH. Rio de Janeiro: Zahar, 1982; MARICATO, Ermínia. Autoconstrução, a arquitetura possível. In MARICATO, Ermínia. A produção capitalista da casa (e da cidade) no Brasil Industrial. São Paulo: Ed. Alfa-Ômega, 1979. 
Quando da criação do BNH, logo após o golpe de estado conservador de março de 1964, o grupo lacerdista ${ }^{4}$ que havia apoiado o golpe conseguiu participar ativamente do projeto de lei que criou o BNH e o SFH e conseguiu fazer o primeiro presidente do Banco, a professora Sandra Cavalcanti. A idéia básica de intervenção habitacional propugnada pelo grupo lacerdista - principalmente por conta de algumas obras que a'Aliança para o Progresso' havia realizado no Estado da Guanabara - era a erradicação de favelas e a construção de grandes conjuntos nas distantes periferias das cidades, que já mostravam sinais de ocupação acelerada. Sob a batuta de Cavalcanti, e seguindo o exemplo da COHAB Guanabara, que já havia sido constituída em 1962, foram criadas de maio de 1964 a outubro de 1965, em aproximadamente 17 meses, 19 COHABs em todo o país.

No entanto, os interesses financistas que apoiaram o golpe de 1964 já haviam notado a importância crescente dos recursos que estavam e estariam mobilizados para o fomento à construção civil. Segundo Aragão, último presidente do BNH, havia uma "cisão exposta dos grupos que se tinham alinhado para a criação do BNH e uma oposição explícita de parte do empresariado da construção civil com vinculações no Ministério do Planejamento [então Roberto Campos] à atuação da presidenta Sandra Cavalcanti" (Aragão, 1999, p. 89). Em 1965, a presidência do BNH foi substituída por equipes ligadas ao Ministério da Fazenda e do Planejamento, que aceleraram as medidas necessárias para implementação do modelo americano de crédito imobiliário, semelhante às savings and loans, mas de alcance nacional, ao contrário do sistema americano à época.

Com a mudança na presidência do BNH e em sua linha de atuação, a concepção financista se tornou hegemônica e a orientação a ser seguida no funcionamento do sistema, cada vez mais nítida. A Lei no. 4.864, de 29 de novembro de 1965, que criou

4 A expressão "grupo lacerdista" designa uma articulação de forças políticas em torno da figura do jornalista Carlos Lacerda. Membro da União Democrática Nacional (UDN), grupo político conservador que se estabeleceu no país durante o curto período democrático vivenciado entre o fim do Estado Novo e o golpe de 1964, Lacerda foi um dos principais expoentes da oposição a Getúlio Vargas e aos chamados governos populistas, aglutinando setores insatisfeitos com as políticas intervencionistas implementadas durante o período mencionado e participando ativamente do movimento que resultou na derrubada do presidente João Goulart e na tomada do poder político pelas forças armadas. 
"medidas de estímulo à construção civil", é um exemplo do que o governo pretendia com a instituição de um sistema financeiro destinado à habitação: incentivos tributários como a isenção de IPI para "preparações e blocos de concreto", normatização de índices e outros instrumentos para a correção monetária de prestações e saldos devedores, independente se os financiamentos encontravam-se ou não no âmbito do SFH, mudança nos limitadores para aplicação dos recursos: 60\% dos recursos aplicados em habitações de valor unitário inferior a 300 salários mínimos (na Lei no. 4.380, de 21 de agosto de 1964, que havia instituído o BNH, esse limite era de 100 salários); 20\% dos recursos aplicados em habitações de valor unitário superior a 400 salários mínimos (na lei do BNH esse limite era 250 salários). A lei 4.864 permitiu também ao Banco Central autorizar as sociedades de crédito e financiamento a se transformarem em sociedades de crédito imobiliário ou a manterem carteira especializada nas operações próprias das sociedades de crédito imobiliário, incentivando dessa forma essas instituições a operar em um sistema integrado de associações de poupanças e empréstimos.

É desse mesmo ano a lei que disciplinou o mercado de capitais, Lei 4.728, de 24 de julho de 1965, que também impactou o SFH, introduzindo correções monetárias trimestrais pela variação da ORTN para prestações, contratos e empréstimos, depósitos e letras imobiliárias.

Os recursos iniciais destinados ao SFH e previstos na lei de criação do BNH/SFH, eram oriun-dos de uma contribuição de 1\% incidente sobre salários, e também de subscrição compulsória de letras imobiliárias emitidas pelo BNH por locadores de imóveis com área superior a $160 \mathrm{~m}^{2}$, por institutos de previdência, SESC, SESI, Caixas Econômicas e promotores da construção de imóveis com valor entre 1000 e 2000 salários mínimos, além de recursos subscritos pela União. No entanto, mesmo depois de um ano de instituído o SFH os recursos ainda não haviam constituído um caixa significativo que pudesse dar um mínimo de escala na produção de unidades habitacionais e com isso fomentar a indústria da construção civil, um dos objetivos prioritários do sistema.

5 Lei no. 4.864, de 29 de novembro de 1965, que cria medidas de estímulo à Indústria de Construção Civil. As citações entre aspas a seguir no texto são de excertos da referida lei. 
Foi de fato a constituição de um fundo parafiscal como o FGTS, por meio da lei

5.107, de 13 de setembro de $1966^{6}$, que deu outro impulso aos recursos antes restritos com os quais operava o Banco. O FGTS é um fundo financeiro formado pela contribuição mensal de empregadores aos seus empregados mediante depósito de $8 \%$ das remunerações em conta vinculada 7 , de natureza privada e sob gestão pública, conformando uma poupança compulsória do trabalhador que o empregador recolhe na fonte. A magnitude dos recursos do FGTS alçou o BNH à condição de segundo estabelecimento bancário do país de sua criação até o início dos anos 70 por conta da aplicação e liquidez de seus recursos ${ }^{8}$.

Os primeiros números do FGTS já demonstram que a constituição do fundo foi de fato um marco na política habitacional brasileira, ainda que a intenção inicial e primeira tenha sido uma compensação pela a substituição da estabilidade no emprego, fundamental para o início do processo de modernização conservadora dos anos 60 .

Pode-se situar a criação do FGTS em uma mudança nos rumos do PAEG, Plano de Ação Econômica do Governo, implementado a partir de 1964. Segundo Oliveira (Oliveira, 2003), logo nos primeiros anos após o golpe de estado, a política de enfrentamento à inflação resultou em uma forte recessão, estendendo-se até 1967, muito em decorrência da contenção dos meios de pagamento. Essa perspectiva foi abandonada em 1967, adotando-se então um aumento dos créditos e dos gastos governamentais.

6 Atualmente o FGTS é regido pela Lei no. 8.036, de 11 de maio de 1990, e regulamentado pelo Decreto no. 99.684, de 08 de novembro de 1990. Dados obtidos nos relatórios de gestão do FGTS de 1999 a 2008 disponíveis em <http://www.caixa.gov.br/fgts $>$.

7 Constituem, ainda, recursos do Fundo: - dotações orçamentárias específicas; - resultados das aplicações dos recursos do FGTS; - multas, correção monetária e juros moratórios devidos; - receitas oriundas da Lei Complementar no. 110/01; - demais receitas patrimoniais e financeiras.

8 Sobre o FGTS é importante ainda salientar que o objetivo do Fundo, expresso na lei que atualmente o regulamenta é: (i) assegurar ao trabalhador optante a formação de um pecúlio relativo ao tempo de serviço em uma ou mais empresas, para ampará-lo em caso de demissão e a seus dependentes em caso de falecimento; e (ii) fomentar políticas públicas por meio do financiamento de programas de habitação popular, de saneamento básico e de infra-estrutura urbana. As normas e diretrizes do FGTS são estabelecidas por seu Conselho Curador, órgão tripartite, composto atualmente por 08 integrantes de órgãos e entidades do Governo Federal, 04 representantes dos trabalhadores e 04 representantes dos empregadores. O agente gestor do FGTS é o Ministério do Trabalho e Emprego, a gestão da aplicação dos recursos do FGTS é efetuada pelo Ministério das Cidades, cabendo à Caixa Econômica Federal o papel de Agente Operador. A Caixa Econômica Federal é também Agente Financeiro do FGTS, partilhando essa função com outras instituições (bancos). 
O aumento dos recursos com os quais o BNH passou a trabalhar significou para alguns autores a mudança do seu perfil visto que

os novos recursos eram de caráter reembolsável, tinham um custo financeiro e administrativo não inferior a 5\% ao ano para o FGTS e 8,5\% para as cadernetas de poupança e letras imobiliárias. [...] O cumprimento dessas novas obrigações exigiria, naturalmente, que as aplicações do BNH e SFH como conjunto tivessem uma ren-tabilidade média suficiente para cobrir os custos financeiros e operacionais e assegurar um mínimo de reservas técnicas destinadas a compensar o risco de eventuais inadimplências dos tomadores dos empréstimos concedidos pelas entidades financiadoras. (Aragão, 1999, p. 98).

Essa mudança de perfil, portanto, se daria exclusivamente pela origem financeira do di-nheiro que comporia a base dos recursos a serem utilizados na execução da política, tal era a visão vigente à época do sistema, que prezava pelo equilíbrio econômico-financeiro e pela constituição do sistema como um fim em si mesmo. Dessa forma, ao mudar a origem do recurso que compunha o funding da política, muda também seu caráter, o que, se por um lado atenta para a necessidade de liquidez e solvabilidade dos recursos, por outro demonstra a preocupação em utilizar os fundos e seus recursos com quem tivesse capacidade financeira para isso, ou seja, financiar quem podia pagar. Recursos orçamentários não eram utilizados para a execução dos programas, nem a título de subsídio, o que ampliava o caráter regressivo da política. $\mathrm{O}$ BNH responderia a essa dificuldade desenhando programas que continham subsídios internos bem como programas que tivessem juros mais altos, como os programas de cooperativas e mercado de hipotecas. Além disso, alguns progra-mas contavam também com subsídios cruzados nos quais famílias de renda um pouco mais alta subsidiavam famílias de renda menor.

De fato, o desempenho do FGTS ao longo do período de funcionamento do BNH assegurou, até 1980, excelentes resultados quantitativos, demonstrando que essa fonte de recursos era de crucial importância tanto do ponto do vista do custo de captação do recurso para a execução de política habitacional para renda média e média baixa, quanto do fomento à indústria da construção civil.

Outro ponto importante no desenho do sistema foi a criação, em 1967, do Fundo 
de Compensação das Variações Salariais (FCVS). O FCVS foi pensado para que a correção monetária instituída no SFH não gerasse um descasamento entre as prestações e o saldo devedor. Ou seja, se, ao final do contrato de financiamento pactuado entre o mutuário e o agente financeiro, houvesse algum saldo devedor (resíduo, na linguagem contábil) e o contrato estivesse coberto pelo FCVS, o fundo pagaria ao agente financeiro essa diferença, sem ônus para o mutuário. Dessa forma, havia a intenção de se constituir um sistema e um fundo que fossem auto-sustentáveis ou que tivessem um equilíbrio econômico-financeiro. O FCVS daria segurança para operações de longo prazo e era alimentado por contribuições dos próprios tomadores de financiamento imobiliário. Seria uma importante garantia para cobrir as eventuais distorções ocorridas ao longo de uma operação de credito imobiliário de 10 a 15 anos, que era a média de tempo dos financiamentos à época. No entanto, o que se viu ao longo dos anos seguintes à sua implementação foi a utilização do FCVS para cobrir passivos contratuais criados por problemas dos índices de correção de prestações e de saldo devedor que superavam e muito a sua condição e mesmo o seu objetivo inicial. A inflação pós choque dos juros americanos de 1979 disparou os valores das prestações e dos saldos devedores e fulminou o FCVS. Atualmente o FCVS detém um passivo de mais de 60 bilhões de reais, cujo devedor final é a União, e seus títulos são ainda utilizados por instituições financeiras para comprovar sua atuação na área habitacional. Voltaremos a esse ponto mais adiante.

A implantação do SBPE também é oriunda desses primeiros anos de funcionamento do BNH e do SFH. O Sistema Brasileiro de Poupança e Empréstimo era composto pelo próprio BNH, que exercia papel de órgão central do sistema, pelas carteiras imobiliárias das caixas econômicas, federal e estaduais, sociedades de crédito imobiliário e associações de poupança e empréstimo. Sua implantação ocorreu paralelamente à estruturação do SFH e do próprio mercado de capitais no país. Até hoje se pode considerar o SBPE como um subsistema ou um sistema auxiliar do SFH.

A incorporação, no entanto, das caixas econômicas ao SBPE foi o que deu mais fôlego ao sistema, especialmente quanto à captação de recursos, visto que as caixas econômicas sempre tiveram tradição de depósitos individuais e grande capilaridade junto ao público em todo o país. 
O SBPE era regulamentado pelo Banco Central e pelo BNH, que expediam normas

que iam desde o controle sobre o funcionamento interno dos agentes integrantes do sistema até as taxas de juros que deveriam ser praticadas. O BNH normatizava e fiscalizava as carteiras imobiliárias das instituições, tratava de todos os assuntos financeiros e também das questões urbanísticas e de tipologia arquitetônica, definindo tipologia de projetos para todo o país, centralizando a maioria das decisões relativas a esse recurso.

Competia ao BNH regulamentar toda a condição de financiamento das operações a cargo do SBPE, planos de reajustes das prestações e do saldo devedor, cobertura eventual do FCVS entre outros temas similares. Também competia ao BNH regulamentar os programas de investimento com os recursos do SBPE, tais como o plano empresário - financiamento da produção de habitações desenvolvido por incorporadores; o programa condomínio - financiamento da produção desenvolvido sem a figura do incorporador; o programa de cons-trução individual da casa própria e o financiamento da construção em terreno próprio.

O primeiro período do BNH e também do SFH correspondeu, portanto, a essa fase de estruturação institucional, com a promulgação das leis do mercado de capitais, da incorporação imobiliária, de medidas de estímulo à industria da construção, estruturação da poupança voluntária e também da formatação e início de operação do FGTS. A estruturação, de um lado, das COHABs enquanto agentes promotores públicos, atendendo a faixa de renda mais baixa, de 0 a 3 salários mínimos, e de outro, de agentes financeiros privados, marcou esse primeiro período de funcionamento tanto do BNH quanto do SFH.

Foi desse período o programa mais paradigmático dessa fase do BNH, o programa Mercado de Hipotecas (criado em novembro de 1966), que buscava implantar no país o sistema bem sucedido das savings and loans americanas. Nesse programa, a construtora e/ou incorporadora (figura do originador das hipotecas ${ }^{9}$ no sistema

9 A figura do que atualmente no mercado imobiliário se conhece como originador de hipotecas é tratada pelo programa Mercado de Hipotecas do BNH como iniciador (a expressão originador, usada atualmente, talvez seja uma forma de anglicismo a posteriori, já que o termo em inglês para o iniciador do processo de hipoteca é originator). 
americano) assinava um contrato com o BNH no qual este se comprometia a ad-

quirir os créditos hipotecários obtidos com a venda das unidades. Esses recursos seriam o lastro de contrato de empréstimo entre o originador e uma instituição financeira (SCl ou banco). O BNH repassava os recursos destinados à construção para essa instituição financeira. Finalizada a construção, as dívidas entre o originador e a instituição financeira eram quitadas e o BNH ficava como credor hipotecário do mutuário final, assumindo todo o risco da operação. O programa buscava a criação de um mercado secundário para os títulos com lastro nos créditos hipotecários. 0 BNH seria o grande investidor institucional, fornecendo recursos para a formação das hipotecas originárias e também criando um fundo para garantir a recompra dos títulos hipotecários caso houvesse problemas de liquidez (inadimplência de mutuários).

Sobre os resultados do programa, tanto do ponto de vista socioeconômico quanto do ponto de vista urbanístico, devemos consultar a pesquisa do Prof. Dr. Gabriel Bolaffi, concluída em 1972, feita a partir de três conjuntos habitacionais construídos com recursos do FGTS entre 1967 e 1968.

Bolaffi faz uma crítica contundente ao desenho do programa, que permitia que "investimentos anuais da ordem quase de Cr\$6 bilhões - ou Cr\$4,1 bilhões se considerados apenas os programas habitacionais" fossem deixados "ao critério de uma multiplicidade de 'iniciadores.' Do ponto de vista urbanístico, por exemplo, os atuais critérios são comparáveis aos de uma metrópole que decida confiar a condução do seu trânsito urbano aos moradores de cada quarteirão" (Bolaffi, 1972, p. 143). O trabalho apresenta os dramáticos efeitos de uma política desenhada pensando prioritariamente no desenho financeiro do reajuste do sistema de prestações e do saldo devedor e deixando, nesse programa específico, sob a responsabilidade da iniciativa privada, toda a decisão sobre o tipo de habitação que seria produzida e sobre qual seria a demanda atendida efetivamente (visto que eram os 'iniciadores' que faziam o cadastro da demanda), ainda que o BNH tivesse alguns instrumentos naquele momento para fiscalizar e exercer seu controle.

O trabalho apresenta uma pesquisa de campo desenvolvida em 1971 visando res- 
ponder inicialmente aos motivos de uma elevada inadimplência em conjuntos habitacionais cons-truídos em três cidades distintas.

Entre as causas do insucesso do programa pode-se indicar: a facilidade com que foram aprovados determinados projetos, no afã de gerar aplicações rápidas para os recursos do FGTS e de ampliar a oferta de novas habitações, a inexperiência do próprio BNH [...] em um ramo de alta complexidade operacional, deficiências de fiscalização no cumprimento das especificações dos projetos, desarticulação com os órgãos estaduais e municipais que deveriam assegurar as obras de infra-estrutura e de equipamentos urbanos requeridas pelos empreendimentos, estudos mercadológicos de confiabilidade duvidosa com a super avaliação da renda dos candidatos à aquisição dos imóveis, descompasso entre os reajustes dos valores das prestações dos financiamentos e dos salários dos adquirentes, etc. [Bolaffi observou assim] elevados índices de inadimplência em muitos dos conjuntos comercializados ou, ainda, o abandono dos imóveis, porta aberta para as ocupações irregulares e a depredação ou deterioração das unidades habitacionais (Bolaffi, 1972, p. 101-102).

Em 1971, o BNH inicia uma importante mudança institucional culminando com a sua formatação em empresa pública (e não mais em autarquia) em 1973. Começa a operar como banco de segunda linha, ou seja, exerce o controle e a fiscalização das operações sem o-perar diretamente com o público. Alguns autores identificam nessa mudança uma busca pela eficácia no retorno dos investimentos bem como uma resposta às críticas por conta do péssimo desempenho do programa Mercado de Hipotecas (Maricato, 1987; Azevedo e Andrade, 1982).

Inicia-se então uma segunda fase do BNH com a criação de programas como o CURA (1972), Fundos Regionais para o Desenvolvimento Urbano (1973), Financiamento para Urbanização (1974), Financiamento para Sistemas Ferroviários para Transporte Urbano de Passageiros (1975), Financiamento para Planejamento Urbano (1975), Apoio ao Desenvolvimento de Pólos Econômicos (1976). Há nitidamente uma mudança visando diversificar os programas para conseguir financiar obras urbanas, como coloca Maricato, tendo como tomadores de empréstimos os estados, municípios e companhias de saneamento. Já os chamados Programas Complementares, criados por volta de 1975, tais como Financiamento para Urbanização de Con- 
juntos Habitacionais, Financiamento de Equipamento Comunitário de Conjuntos

Habitacionais e Financiamento de Lotes Urbanizados diferenciam-se dos programas de financiamento a grandes obras urbanas (que procurava atender e investir em outro tipo de cliente) pois são destinados a dotar de infra-estrutura os próprios conjuntos financiados com recursos do BNH. Segundo Maricato, os programas destinados a financiar obras urbanas visavam injetar recursos na construção civil colaborando no pool de obras do 'milagre brasileiro', ou mesmo protagonizando algumas dessas obras. Como exem-plo, podemos citar que o BNH investiu na "construção de apoio urbano à usina hidrelétrica de Tucuruí, o que incluía um aeroporto para aeronaves de categoria do Boeing 727" (Maricato, 1987, p. 36). Parte dessa mudança pode ser entendida como a necessidade do BNH de buscar clientes com capacidade de pagamento, visto que o principal programa de habitação popular, o Mercado de Hipotecas, tinha sido um fracasso, resultando em taxas altíssimas de inadimplência.

Em 1973, o BNH lança o Plano Nacional de Habitação Popular (PLANHAP), com

discursos e pronunciamentos oficiais [que] iriam repetir, ironicamente, os mesmos objetivos e intenções que fundamentaram a criação do BNH e do SFH [...] A habitação popular e a erradicação do déficit habitacional brasileiro estão no centro das justificativas para a criação do Plano Nacional de Habitação em 1964 e do Plano Nacional de Habitação Popular em 1973. Novamente são lembrados os benefícios que o BNH trará ao desenvolvimento do país através do estímulo à indústria da construção e através da geração de milhares de empregos diretos e indiretos". (Maricato, 1987, p. 42) [sem grifo no original]

O lançamento do PLANHAP é um reconhecimento público por parte do governo de que o BNH e o SFH não haviam logrado atender ao público para o qual havia sido criado, cons-tatando que a Carteira de Operação de Natureza Social representava em 1974, 8,21\% do total dos financiamentos concedidos pelo SFH, enquanto que a carteira do SBPE representava nesse mesmo ano, 60,61\% do total de financiamentos do SFH (Maricato, 1987).

No entanto, é a partir de 1975 que alguns resultados dos programas destinados a faixa de mais baixa renda começam a aparecer, especialmente nos resultados quantitativos dos programas vinculados às COHAB. Essa seria uma terceira etapa do BNH, 
no qual a Carteira de Operações Sociais ganha alguma expressão no SFH. É bom notar que, em 1976, as COHABs passam a atender também a faixa de renda de 3 a 5 salários mínimos, e que boa parte dos financiamento se situam nas faixas de 4 e 5 salários mínimos.

A quarta e última etapa do $\mathrm{BNH}$, antes da grave crise que acomete o equilíbrio financeiro do sistema a partir de 1983, foi a criação dos programas ditos alternativos como o Financiamento da Construção ou Melhoria de HIS (1977), a reformulação do Programa de Lotes Urbanizados (1978), e o Programa de Erradicação da Sub Habitação (1979).

Esses programas alternativos podem ser compreendidos com mais clareza à luz do $2^{\circ}$ PND (Plano Nacional de Desenvolvimento), que procurava conduzir um reformismo conservador como renovação do projeto político do regime autoritário. Buscava incorporar a estratégia reformista do Banco Mundial, presidido então por McNamara, que propugnava a redistribution with growth (Melo, 1988). No entanto, esse crescimento era focado não em uma política salarial descomprimida, buscando uma efetiva redistribuição de renda, mas sim em políticas sociais que buscavam intervenções que impactassem rapidamente sem, no entanto, reverter a condição estrutural na qual se encontravam as famílias moradoras de favelas e outros tipos de assentamento sub-normais.

Em relação à evolução do SBPE, pode-se notar uma mudança ao longo dos anos 70 que corresponde à maior concentração do sistema bancário. Nos primeiros anos de funcionamento do SBPE os principais agentes eram as sociedades de crédito imobiliário independentes e as associações de poupança e empréstimo. Por suas características de captação de poupança voluntária e de empréstimos destinados ao crédito imobiliário, ficavam sob a tutela do BNH, que determinava as normas e regulamentos para seu funcionamento.

No entanto, com a maior concentração do sistema financeiro nacional, promovida pelo Banco Central, muitas das sociedades de crédito imobiliário (SCI) independentes e das associações de poupança e empréstimo (APE) foram liquidadas ao longo da década de 70, restando cada vez mais SCls vinculadas a grandes bancos comer- 
ciais e a bancos públicos. Essa concentração das SCls fortaleceram-nas na medida em que já não precisavam de recursos do BNH para o refinanciamento de suas dívidas. No entanto, a destinação dessa captação de poupança voluntária para o crédito habitacional foi sendo cada vez mais fonte de disputa entre o próprio BNH e os grandes bancos comerciais que pressionavam o Banco Central visando 'desregulamentar' o mercado, "o que, na prática, equivalia a permitir um maior volume de operações com recursos das cadernetas fora do setor habitacional, aumentar os limites unitários de financiamento, eliminar as restrições ao financiamento de imóveis usados e admitir maiores taxas efetivas de juros, através de aumento das comissões de abertura de crédito" (Aragão, 1999, p. 204).

Mesmo alguns meses antes da extinção do BNH, em dezembro de 1986, todo o controle das cadernetas de poupança havia passado para o Banco Central, indicando qual a direção deveria ser dada ao vultoso volume de recursos depositados nas cadernetas de poupança do país. Com a extinção do BNH toda a regulamentação do crédito habitacional e imobi-liário passa para Banco Central e para o Conselho Monetário Nacional, reforçando o viés de política monetária nas concessões desse tipo de crédito. O agente financeiro do SFH torna-se então a Caixa Econômica Federal.

Em 1983, com o recrudescimento da inflação, o reajuste das prestações foi feito com 80\% da variação do salário mínimo (uma das opções oferecidas aos mutuários), índice sem relação com o que foi aplicado aos saldos devedores, gerando um descasamento importante entre o ativo e o passivo do financiamento. Em 1985, os saldos devedores foram corrigidos em $246 \%$, creditado aos detentores de contas de poupança e do FGTS, enquanto as prestações foram reajustadas em 112\% (Aragão, 1999). Em 1986, por conta do Plano Cruzado, as prestações foram convertidas para a moeda então criada, o cruzado, pelas médias aritméticas das prestações dos seis ou doze meses anteriores a março de 1986, atingindo a totalidade dos contratos.

Dessa forma, observa-se que o descasamento entre os indexadores das operações e os encargos mensais foram fatores cruciais para o desmoronamento do sistema. Também a queda acentuada dos salários, e a alta inadimplência daí decorrente, a expressiva queda de arrecadação do FGTS, originada principalmente por redução 
de salários, desemprego, saques elevados das contas do fundo e crescente informalização da economia, tiveram importância na derrocada do equilíbrio econômico-financeiro do BNH. Fatos que podem ser interpretados como conseqüências da crise internacional na economia brasileira observadas no aumento do desemprego (e, portanto dos saques do FGTS) no aumento da inadimplência e na queda da captação da poupança.

Alguns autores ${ }^{10}$ atribuem também o desequilíbrio do sistema, e mesmo sua extinção, a uma política indiscriminada de concessão de subsídios nas prestações. Decisões do Ministério do Interior e do próprio BNH estenderam benefícios de correção das prestações muito abaixo da inflação a todos os mutuários, sem distinção.

Fragilizado pela crescente crise financeira, o sistema integrado, raiz da moderna política habitacional brasileira, se desarticula. Seja pela extinção propriamente dita do BNH (fragmentação institucional), seja pelo esgotamento do modelo de financiamento (fragmentação financeira), o modelo caminha para a desestruturação em meados dos anos 80 .

Além disso, o auge da crise financeira e institucional do sistema coincidiu com a crise do regime militar, que levou à abertura gradual do país no final da década de 70. Assim como outras políticas públicas afetadas pela crise econômica do período pós-milagre, a política habitacional foi duramente atingida no seu duplo aspecto de constituição. De um lado, a crise econômica acarretava altas taxas de inadimplência e diminuição do nível de empreendimento, pela escassez do financiamento público e pela progressiva queda do poder aquisitivo da população. De outro, as políticas do $\mathrm{BNH}$, por estarem diretamente ligadas ao regime, uma das fontes de sua legitimação, passaram a ser questionadas juntamente com ele, tornando-se símbolo do passado que se queria enterrar.

Importante também apontar que a grande massa de recursos do Sistema Financeiro

10 Ver ARRETCHE, Marta. Desarticulação do BNH e Autonomização da Política Habitacional. In: AFFONSO, Rui B. A.; SILVA, Pedro L. B. (Orgs.). Descentralização e Políticas Sociais. São Paulo: FUNDAP, 1996, p. 107-138; ARAGÃO, José Maria. Sistema Financeiro da Habitação: uma Análise Sácio-Jurídica da Gênese, Desenvolvimento e Crise do Sistema. Curitiba: Juruá,1999; MELO, Marcus André B. C. Anatomia do Fracasso: Intermmediação de Interesses e a Reforma das Políticas Sociais na Nova República. In Revista de Ciências Sociais, Vol. 36, no. 1. Rio de Janeiro: IUPERJ, 1993. 
da Habitação administrada pelo BNH impactava diretamente na política monetária e fiscal do governo, especialmente após o choque do petróleo em 1979. Dessa forma, não se pode ignorar os efeitos desse volume de recursos no desenho da política econômica do governo, por conta de sua especificidade enquanto política de crédito e de fomento à indústria da construção civil e de bens duráveis (Melo, 1988).

Após a extinção do BNH, o então Ministério de Desenvolvimento Urbano e Meio Ambiente ficou com a incumbência de formular a política habitacional e de desenvolvimento urbano. O Conselho Monetário Nacional, CMN, e o Banco Central do Brasil, BACEN, tornaram-se os órgãos controladores do sistema, cabendo ao primeiro as funções de orientar, disciplinar e controlar e ao segundo a fiscalização das instituições financeiras integrantes do sistema. À Caixa Econômica Federal coube a gestão do FGTS e a administração dos contratos ativos e passivos, bem como dos bens móveis e imóveis e do quadro de pessoal do BNH.

O Conselho Monetário Nacional (CMN), ao assumir o controle das cadernetas de poupança e, portanto, do SBPE, baixou normas sobre os limites de aplicação e exigibilidades que demonstram o viés financeiro adotado. Já em janeiro de 1986, antes, portanto, da extinção do BNH, o CMN determina que as SCls e as APEs, bem como as caixas econômicas, recolham ao Banco Central 25\% dos saldos dos depósitos de poupança, reduzindo dessa forma os recursos para aplicação em financiamentos imobiliários (Resolução CMN no 1.090 de 30 de janeiro de 1986). Importante recordar que era o BNH que determinava aos participantes do SBPE (SCls, APEs, carteiras de poupança de Bancos Múltiplos) o percentual e a forma que os recursos aplicados por poupadores na caderneta deveriam ser utilizados, o quanto deveria ser utilizado para financiar habitação, para qual faixa de renda e o quanto deveria ser recolhido ao Banco Central para compor as reservas monetárias do país. Às condições de aplicação dos recursos em financiamentos habitacionais se dá o nome de direcionamento dos recursos da poupança.

Mas foi após a extinção do BNH e, na esteira dos planos de estabilização econômica, que o CMN moldou o SFH tal como ele se encontra nos anos 2000. A Resolução CMN no. 1.446, de 05 de janeiro de 1988, por exemplo, determinou que dos 65\% de 
recursos que deveriam obrigatoriamente ser investidos em financiamentos habitacionais (exigibilidade), 20\% deveriam ser aplicados em financiamentos habitacionais, a taxas de mercado, ou seja, livre dos controles e limites do SFH, 10\% em operações de financiamento do SFH com valor de até 2.500 OTN (o que equivaleria hoje a algo em torno de $R \$ 40.000,00^{11}$ ) e 35\% na faixa de 2.500 a 5.000 OTN (entre $R \$ 40$ mil e R\$ 80 mil, aproximadamente). Para cumprir a exigibilidade, tanto na faixa até 2.500 OTN quanto na faixa subseqüente, as instituições financeiras poderiam apresentar ao Banco Central créditos junto a fundos criados ainda no BNH destinados a dar suporte a habitação popular tais como o Fundo de Apoio à Produção de Habitações para a População de Baixa Renda (FAHBRE) e ao Fundo de Estabilização (FESTA), bem como créditos junto ao FCVS. Na prática, disso resultou a queda substancial de operações no âmbito do SBPE destinadas às faixas de renda média e média baixa e a utilização de seus recursos como instrumento da política monetária e da política de estabilização econômica, em detrimento do aporte de recursos para a produção habitacional.

Em 1989, por meio do Plano Verão, e em 1990, por meio do Plano Collor, com o bloqueio de todos os ativos financeiros do sistema financeiro nacional, 60\% do saldo das cadernetas, principal funding das operações de credito imobiliário, ficou bloqueado no Banco Central. Metade dos 40\% restantes foi retirado pelos depositantes. Dessa forma, de um saldo de 30 bilhões que lastreava o SBPE na época, caiu-se, em um ano, a aproximadamente 7 bilhões (ABECIP, 2007). O bloqueio da poupança fez com que o funding, que fornecia condições para que o sistema pudesse operar, praticamente deixasse de existir. A partir daí a captação de recursos da poupança foi crítica durante toda a década de 90 em comparação com os números da década de 70.

Além disso, o Plano Cruzado, o Plano Verão e o Plano Collor, ao congelar prestações, propor reajustes abaixo da inflação do período e usar índices distintos para prestações e saldos devedores também geraram defasagens significativas nos contratos,

11 O cálculo para encontrar o valor atual dos financiamentos foi feito com base no dólar. Em 04 de janeiro de 1988, um dólar valia Cz\$71,892 (cruzados) na compra, de modo que o valor desse financiamento corresponderia a 20.758,22 dólares à época. Em julho de 2008, o dólar vale aproximadamente $R \$ 2,00$ (reais), perfazendo o valor do teto de financiamento mais baixo, 2.500 OTNs, R\$ 41.516,44. 
explodindo o passivo do FCVS.

Porém, mais de 40 anos após sua criação, a avaliação do SFH quanto ao seu desempenho ainda divide analistas acadêmicos e é fonte de disputa ideológica. A análise progressista vê no período de vigência do BNH toda a regressividade do investimento a despeito do reco-nhecimento da importância de sua arquitetura institucional e financeira. A crítica de filiação neoclássica analisa o BNH e o SFH identificando uma forte intervenção estatal no mercado imobiliário e habitacional, imputando a essa intervenção boa parte da causa de seu fracasso no cumprimento de sua agenda inicial.

No entanto, o saldo de unidades habitacionais construídas no período, tanto com recursos do FGTS quanto com recursos do SBPE é muito significativo, como se nota na tabela 1. Certamente o desempenho extremamente desigual ao longo desses anos é uma prova factual de que é a disputa dos grupos de interesse em torno do orçamento e da gestão das poupanças voluntária e compulsória que realmente conforma a política pública.

Importante ressaltar a queda significativa de financiamentos que ocorreu a partir de 1983. Como se trata de unidades financiadas, há um intervalo de tempo entre a contratação e a finalização e entrega das unidades, o que explica porque o número de unidades só apresenta uma queda no ano de 1983. No entanto, as contratações diminuíram sensivelmente a partir de 1980, por conta das condições macroeconômicas internacionais e seu reflexo nos países subdesenvolvidos, especialmente no Brasil. O choque da taxa de juros americana em 1979 elevou os preços de tal forma que fez a inflação já crescente no Brasil no final dos anos 70 chegar em patamares que inviabilizavam políticas de longo prazo para o crédito. Como é sabido, toda a década de 80 sofreu com a inflação que corroia o poder de compra de toda a população. Os números do SFH expressam essa queda vertiginosa do crédito.

Em relação ao parque construído habitacional, no período de 1964 a 1986, segundo os PNADs e os censos realizados, 15,5 milhões de novas unidades habitacionais foram erguidas, sendo financiadas pelo SFH, conforme visto na Tabela 1, aproximadamente 4,45 milhões de unidades. Pode-se afirmar, portanto, que aproximadamente 
TABELA 1

SFH / BNH: Financiamentos habitacionais concedidos - Unidades Habitacionais e Valores - 1970 a 1986.

\begin{tabular}{|c|cc|cc|c|}
\hline \multirow{2}{*}{ Ano } & \multicolumn{2}{|c|}{ FGTS } & \multicolumn{2}{c|}{ SBPE* $^{*}$} & \multicolumn{1}{c|}{ TOTAL } \\
\cline { 2 - 5 } & No Período & Acumulado (1) & No Período $\quad$ Acumulado (2) & No Período & Acumulado (1+2) \\
\hline
\end{tabular}

\begin{tabular}{|c|cc|cc|cc|}
\hline 1970 & 73.144 & $R \$ 363.358,00$ & 84.086 & $R \$ 222.192,00$ & 157.230 & $R \$ 585.550,00$ \\
\hline 1971 & 59.059 & $R \$ 422.417,00$ & 58.531 & $R \$ 280.723,00$ & 117.590 & $R \$ 703.140,00$ \\
\hline 1972 & 47.804 & $R \$ 470.221,00$ & 76.685 & $R \$ 357.408,00$ & 124.489 & $R \$ 827.629,00$ \\
\hline 1973 & 61.178 & $R \$ 531.399,00$ & 96.623 & $R \$ 454.031,00$ & 157.801 & $R \$ 985.430,00$ \\
\hline 1974 & 35.937 & $R \$ 567.336,00$ & 60.268 & $R \$ 514.299,00$ & 96.205 & $R \$ 1.081 .635,00$ \\
\hline 1975 & 77.417 & $R \$ 644.753,00$ & 64.512 & $R \$ 578.811,00$ & 141.929 & $R \$ 1.223 .564,00$ \\
\hline 1976 & 164.353 & $R \$ 809.106,00$ & 109.410 & $R \$ 688.221,00$ & 273.763 & $R \$ 1.497 .327,00$ \\
\hline 1977 & 209.709 & $R \$ 1.018 .815,00$ & 58.004 & $R \$ 746.225,00$ & 267.713 & $R \$ 1.765 .040,00$ \\
\hline 1978 & 279.516 & $R \$ 1.298 .331,00$ & 58.133 & $R \$ 804.358,00$ & 337.649 & $R \$ 2.102 .689,00$ \\
\hline 1979 & 274.238 & $R \$ 1.572 .569,00$ & 108.985 & $R \$ 913.343,00$ & 383.223 & $R \$ 2.485 .912,00$ \\
\hline 1980 & 366.808 & $R \$ 1.939 .377,00$ & 260.534 & $R \$ 1.173 .877,00$ & 627.342 & $R \$ 3.113 .254,00$ \\
\hline 1981 & 198.514 & $R \$ 2.137 .891,00$ & 266.884 & $R \$ 1.440 .761,00$ & 465.398 & $R \$ 3.578 .652,00$ \\
\hline 1982 & 282.384 & $R \$ 2.420 .275,00$ & 258.745 & $R \$ 1.699 .506,00$ & 541.129 & $R \$ 4.119 .781,00$ \\
\hline 1983 & 32.685 & $R \$ 2.452 .960,00$ & 44.562 & $R \$ 1.744 .068,00$ & 77.247 & $R \$ 4.197 .028,00$ \\
\hline 1984 & 43.551 & $R \$ 2.496 .511,00$ & 42.807 & $R \$ 1.786 .875,00$ & 86.358 & $R \$ 4.283 .386,00$ \\
\hline 1985 & 25.005 & $R \$ 2.521 .516,00$ & 34.652 & $R \$ 1.821 .527,00$ & 59.657 & $R \$ 4.343 .043,00$ \\
\hline 1986 & 44.350 & $R \$ 2.565 .866,00$ & 62.312 & $R \$ 1.883 .839,00$ & 106.662 & $R \$ 4.449 .705,00$ \\
\hline
\end{tabular}

Fonte: Banco Central, ABECIP e CAIXA. Extraído do livro: "História e Perspectivas do Crédito Imobiliário - ABECIP 36 anos". Elaboração: Banco de Dados CBIC. (*) O número de moradias financiadas com recursos do SBPE de imóveis (novos e usados) e para a construção é obtido pela soma dos financiamentos para a aquisição

GRÁFICO 1

SFH / BNH: Financiamentos habitacionais concedidos - Unidades Habitacionais - 1970 a 1986.

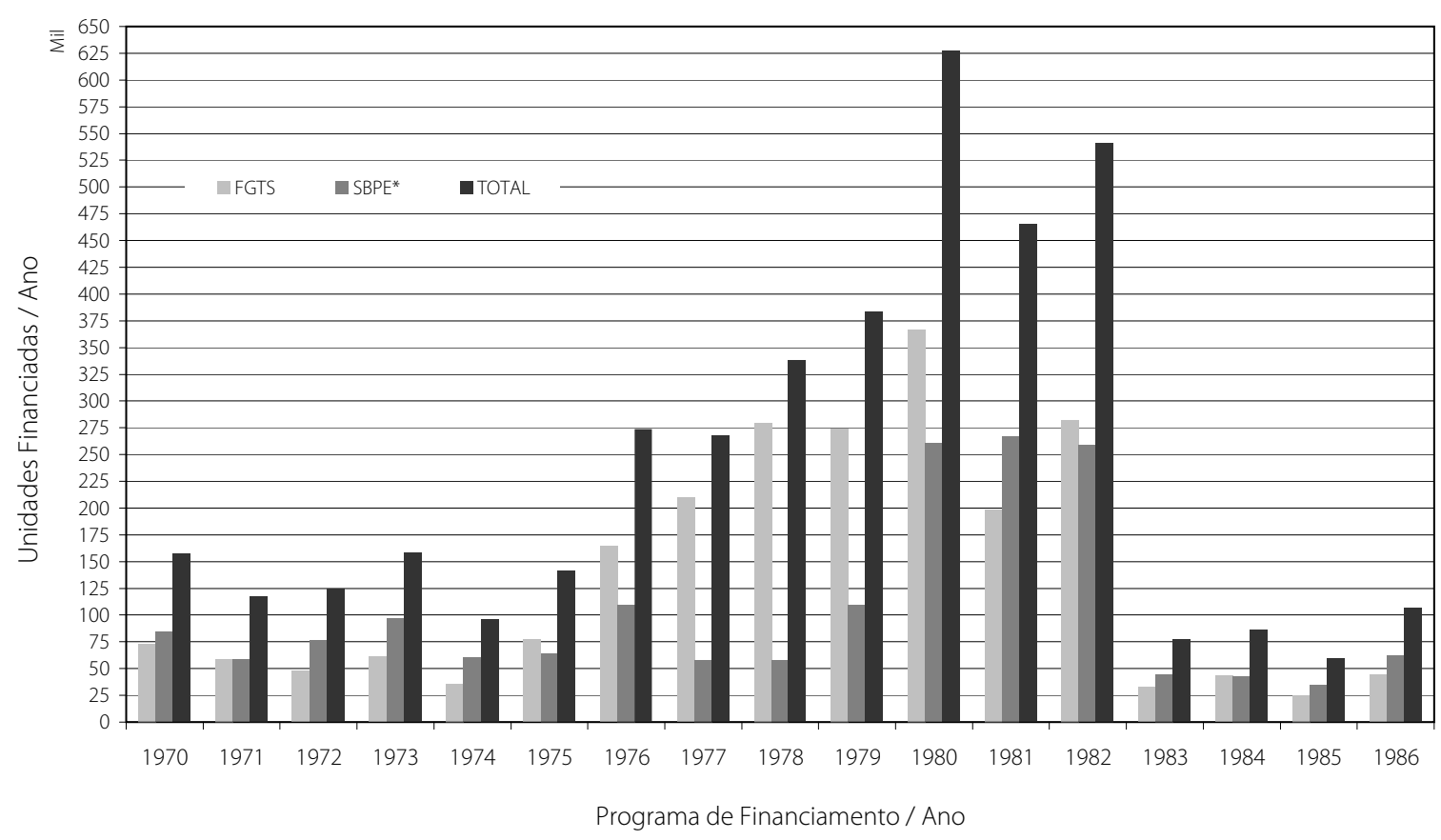


25\% do total de novas unidades do país contaram com financiamento nos moldes do SFH ${ }^{12}$, sendo o restante construída com autofinanciamento e autoconstrução. Voltaremos a esse ponto no capítulo 4.

Destas 4,45 milhões de unidades, no entanto, somente 33,1\% foi destinada para faixas de renda de 1 a 3 salários mínimos (ver Tabela 2).

Por esse motivo talvez seja mais interessante utilizarmos dados que balizam a análise da produção do BNH contextualizando-a na produção destinada a determinadas faixas de renda.

A Tabela 2 mostra que 231.963 financiamentos foram destinados para a faixa de renda de 1 a 3 salários mínimos de 1980 a 1986, sendo que nesse mesmo período, 1.119.550 financiamentos foram concedidos para população com mais de 10 salários mínimos. Se considerarmos somadas, além da primeira faixa, de 1 a 3 salários, a faixa subseqüente, de 3 a 5 salários, o número de financiamentos concedidos vai a 727.511. Ainda assim, esse número representa 64\% do total de financiamentos concedidos à população com mais de 10 salários. Mesmo que sejam somados todos os programas destinados a faixa de renda de 1 a 10 salários mínimos (agregação que coloca no mesmo patamar faixas de renda muito diferentes), o valor alcançado ainda é menor do que o total financiado para mais de 10 salários mínimos no período mostrado na tabela abaixo: 1.038.471 financiamentos concedidos para faixa de renda de 1 a 10 salários mínimos e 1.119 .550 para população com mais de 10 salários.

TABELA 2

SFH / BNH: Número de financiamentos habitacionais concedidos por ano - 1980 a 1986.

\begin{tabular}{|c|c|c|c|c|c|c|c|c|c|c|c|}
\hline \multirow[b]{2}{*}{ Ano } & \multicolumn{3}{|c|}{1 a 3 S.M. (a) } & \multicolumn{3}{|c|}{3 a 5 S.M. (b) } & \multicolumn{2}{|c|}{5 a 10 S.M. (c) } & \multirow{2}{*}{$\begin{array}{c}\text { Subtotal } \\
(a+b+c)=(d) \\
1 \text { a } 10 \text { S.M. }\end{array}$} & \multirow[b]{2}{*}{$>10$ S.M. (2)(e) } & \multirow[b]{2}{*}{ TOTAL (d+e) } \\
\hline & $\begin{array}{l}\text { Joăo-de } \\
\text { Barro }\end{array}$ & Promorar & Total & COHAB's & FICAM & Total & $\begin{array}{l}\text { Cooperativas } \\
\text { (1) }\end{array}$ & Total & & & \\
\hline
\end{tabular}

\begin{tabular}{|r|rrr|rrr|rr|r|r|r|r|}
\hline 1980 & 0,00 & $84.718,00$ & $84.718,00$ & $115.212,00$ & $5.378,00$ & $120.590,00$ & $68.212,00$ & $68.212,00$ & $273.520,00$ & $288.923,00$ & $562.443,00$ \\
\hline 1981 & 0,00 & $45.970,00$ & $45.970,00$ & $80.024,00$ & $10.290,00$ & $90.314,00$ & $70.203,00$ & $70.203,00$ & $206.487,00$ & $244.446,00$ & $450.933,00$ \\
\hline 1982 & 0,00 & $50.961,00$ & $50.961,00$ & $127.002,00$ & $23.249,00$ & $150.251,00$ & $86.772,00$ & $86.772,00$ & $287.984,00$ & $270.127,00$ & $558.111,00$ \\
\hline 1983 & 0,00 & $12.300,00$ & $12.300,00$ & $16.469,00$ & 148,00 & $16.617,00$ & $25.045,00$ & $25.045,00$ & $53.962,00$ & $143.016,00$ & $196.978,00$ \\
\hline 1984 & $6.445,00$ & $15.929,00$ & $22.374,00$ & $61.190,00$ & $3.835,00$ & $65.025,00$ & $27.236,00$ & $27.236,00$ & $114.635,00$ & $101.925,00$ & $216.560,00$ \\
\hline 1985 & $1.072,00$ & $5.552,00$ & $6.624,00$ & $28.143,00$ & 0,00 & $28.143,00$ & $22.470,00$ & $22.470,00$ & $57.237,00$ & $65.121,00$ & $122.358,00$ \\
\hline 1986 & $2.243,00$ & $6.773,00$ & $9.016,00$ & $17.053,00$ & $7.555,00$ & $24.608,00$ & $11.022,00$ & $11.022,00$ & $44.646,00$ & $5.992,00$ & $50.638,00$ \\
\hline
\end{tabular}

Fonte: NEPP, 1986 apud ROYER, 2003.

(1) Inclui Institutos, PHOASP, Hipotecas, Empresas e Sindicatos; (2) Inclui SBPE, RECON e PRODEPO.

12 Dados disponíveis na tabela "Nível de Intermediação financeira na construção habitacional do Brasil (1964/1986)", in Castro, 1999, p.96. 
Ao considerarmos todo o período de vigência do BNH (Tabela 3), chega-se ao núme-

ro já conhecido de aproximadamente 1,5 milhão de financiamentos concedidos no âmbito do mercado popular, somando-se as unidades feitas via COHABs com os programas alternativos do tipo João de Barro (apoio à autoconstrução) e programas de lotes urbanizados. Comparando-se com outros resultados do SFH, esse número representa aproximadamente $68 \%$ dos financiamentos destinados ao mercado médio, acima de 10 salários, e ainda 33,5\% de toda a produção do SFH no período.

De 1987 a 1994 o volume de recursos e a quantidade de financiamento concedido expressam a direção errática da política habitacional, tratada de forma clientelística e assistencialista, segundo Castro (Castro, 1999), e a ausência de uma institucionalidade federal consistente na execução de uma política nacional de habitação. Apesar das inúmeras reuniões e grupos de trabalho, expediente largamente utilizado nos primeiros anos do governo Sarney, a transição democrática na área habitacional restou inconclusa, como sugere Melo (Melo, 1989), já que nenhum projeto envolvendo uma reestruturação do sistema foi implementado. Houve uma dissolução das estruturas institucionais e uma dispersão das atribuições do SFH, o que parece demonstrar um reforço da dimensão financeira da política habitacional ${ }^{13}$.

TABELA 3

SFH / BNH: Número de financiamentos habitacionais concedidos entre 1964 e julho de 1986.

\begin{tabular}{|c|l|c|c|}
\hline \multirow{3}{*}{ Mercado Popular } & Programas Tradicionais - COHABs & 1.235 .409 & $27,7 \%$ \\
\cline { 2 - 4 } & Programas Alternativos (1) & 264.397 & $5,9 \%$ \\
\cline { 2 - 4 } & Total & $\mathbf{1 . 4 9 9 . 8 0 6}$ & $\mathbf{3 3 , 6 \%}$ \\
\hline \multirow{3}{*}{ Mercado Econômico } & Cooperativas & 488.659 & $10,9 \%$ \\
\cline { 2 - 4 } & Outros Programas (2) & 299.471 & $6,7 \%$ \\
\cline { 2 - 4 } & Total & $\mathbf{7 8 8 . 1 3 0}$ & $\mathbf{1 7 , 6 \%}$ \\
\hline \multirow{3}{*}{ Mercado Médio } & SBPE & 1.898 .975 & $42,5 \%$ \\
\cline { 2 - 4 } & Outros Programas (3) & 280.418 & $\mathbf{6 , 3} \%$ \\
\cline { 2 - 4 } & Total & 2.179 .393 & $48,8 \%$ \\
\hline & Total SFH & $\mathbf{4 . 4 6 7 . 3 2 9}$ & $\mathbf{1 0 0 \%}$ \\
\hline
\end{tabular}

Fonte: SACHS, 1999 apud Royer 2003.

(1) Promorar; João-de-Barro; FICAM; Profilurb; (2) Instituto, Hipoteca, Emp.P / Pron., Prosin; (3) Recon; Prodepo.

13 As análises de Melo e Arretche sobre a coalizão de interesses nas reformas sociais da Nova República e a desarticulação institucional do setor habitacional são fundamentais para se compreender melhor o período. Ver MELO, Marcus André B. C. Classe, burocracia e intermediação de interesses na formação da política de habitação. Revista Espaço e Debates, v. 24, 1988; ARRETCHE, Marta T. S. Desarticulação do BNH e autonomização da política habitacional. In AFFONSO, Rui B.A; SILVA, Pedro Luiz B. (orgs.). Descentralização e Políticas Sociais. São Paulo: FUNDAP, 1996. MELO, Marcus André B.C. Anatomia do Fracasso: Intermediação de Interesses e a Reforma das Políticas Sociais na Nova República. DADOS-Revista de Ciências Sociais, Rio de Janeiro, vol. 36, n¹, 1993. 
Com a extinção dos programas do BNH e com a assunção de novos programas que

tiveram curta duração, os dados apresentados a seguir mostram a queda do volume de financiamentos concedidos.

No governo Collor, a criação do PAlH - Plano de Ação Imediata para Habitação, demonstrou, por via da estrutura administrativa, marcada pela subordinação institucional da habitação como questão de assistência social, que as decantadas reformas progressistas do começo da Nova República tinham sido um fracasso ${ }^{14}$.

TABELA 4

SFH: Evolução do número de moradias financiadas entre 1987 ae1994.

\begin{tabular}{|c|cc|cc|cc|}
\hline \multirow{2}{*}{ Ano } & \multicolumn{2}{|c|}{ FGTS } & \multicolumn{2}{c|}{ SBPE* } & \multicolumn{2}{c|}{ TOTAL } \\
\cline { 2 - 7 } & No Período & Acumulado (1) & No Período & Acumulado (2) & No Período & Acumulado (1+2) \\
\hline \hline 1987 & 99.227 & $R \$ 2.665 .093,00$ & 132.005 & $R \$ 2.015 .844,00$ & 231.232 & $R \$ 4.680 .937,00$ \\
\hline 1988 & 98.249 & $R \$ 2.763 .342,00$ & 181.834 & $R \$ 2.197 .678,00$ & 280.083 & $R \$ 4.961 .020,00$ \\
\hline 1989 & 31.617 & $R \$ 2.794 .959,00$ & 68.089 & $R \$ 2.265 .767,00$ & 99.706 & $R \$ 5.060 .726,00$ \\
\hline 1990 & 165.617 & $R \$ 2.960 .576,00$ & 74.993 & $R \$ 2.340 .760,00$ & 240.610 & $R \$ 5.301 .336,00$ \\
\hline 1991 & 359.719 & $R \$ 3.320 .295,00$ & 41.050 & $R \$ 2.381 .810,00$ & 400.769 & $R \$ 5.702 .105,00$ \\
\hline 1992 & 43.801 & $R \$ 3.364 .096,00$ & 64.869 & $R \$ 2.446 .679,00$ & 108.670 & $R \$ 5.810 .775,00$ \\
\hline 1993 & 4.256 & $R \$ 3.368 .352,00$ & 53.708 & $R \$ 2.500 .387,00$ & 57.964 & $R \$ 5.868 .739,00$ \\
\hline 1994 & - & $R \$ 3.368 .352,00$ & 61.384 & $R \$ 2.561 .771,00$ & 61.384 & $R \$ 5.930 .123,00$ \\
\hline
\end{tabular}

Fonte: Banco Central, ABECIP e CAIXA. Extraído do livro: "História e Perspectivas do Crédito Imobiliário - ABECIP 36 anos". Elaboração: Banco de Dados CBIC.

(-) Dado não disponível;

O Plano de Ação Imediata para a Habitação previa a construção, em caráter emergencial, de aproximadamente 245 mil unidades em 180 dias, por meio da contratação de empreiteiras privadas.

Os programas do governo Collor se dividem em três tipos ou modalidades: de urbanização de áreas de regularização fundiária (Produrb-Habitação); de habitação

14 As políticas da Nova República, suas características e seus impactos, especialmente na política habitacional podem ser melhor compreendidas por meio de trabalhos já clássicos sobre o tema. Ver NEPP/IE. Brasil 1985. Relatório sobre a situação social do país, vol. 2, Campinas: Ed. Unicamp, 1986; O’DONNELL, Guillermo. Transição Democrática e Políticas Sociais. Revista de Administração Pública. Rio de Janeiro, v.21, n. 4, p. 9-16, out./dez. 1987; FERNADES, Florestan. Nova República? Rio de Janeiro: Jorge Zahar Editor, 3 ed., 1986, p. 74-75; NETO, Eleutério Rodriguez. O "Social" na Nova República, e também, SOUZA, Herbert de. A Nova República e as Políticas Sociais. Revista de Administração Pública. Rio de Janeiro, v.21, n. 4, p.24-30 e p.16-23, out./dez. 1987; ARRETCHE, Marta. Política Habitacional entre 1986 e 1994. In ARRETCHE, Marta; RODRIGUEZ, Vicente (Orgs.) Descentralização das Políticas Sociais no Estado de São Paulo. São Paulo: FUNDAP: FAPESP; Brasília: IPEA, 1998. 
GRÁFICO 2

SFH: Evolução do número de moradias financiadas entre 1987 e 1994.

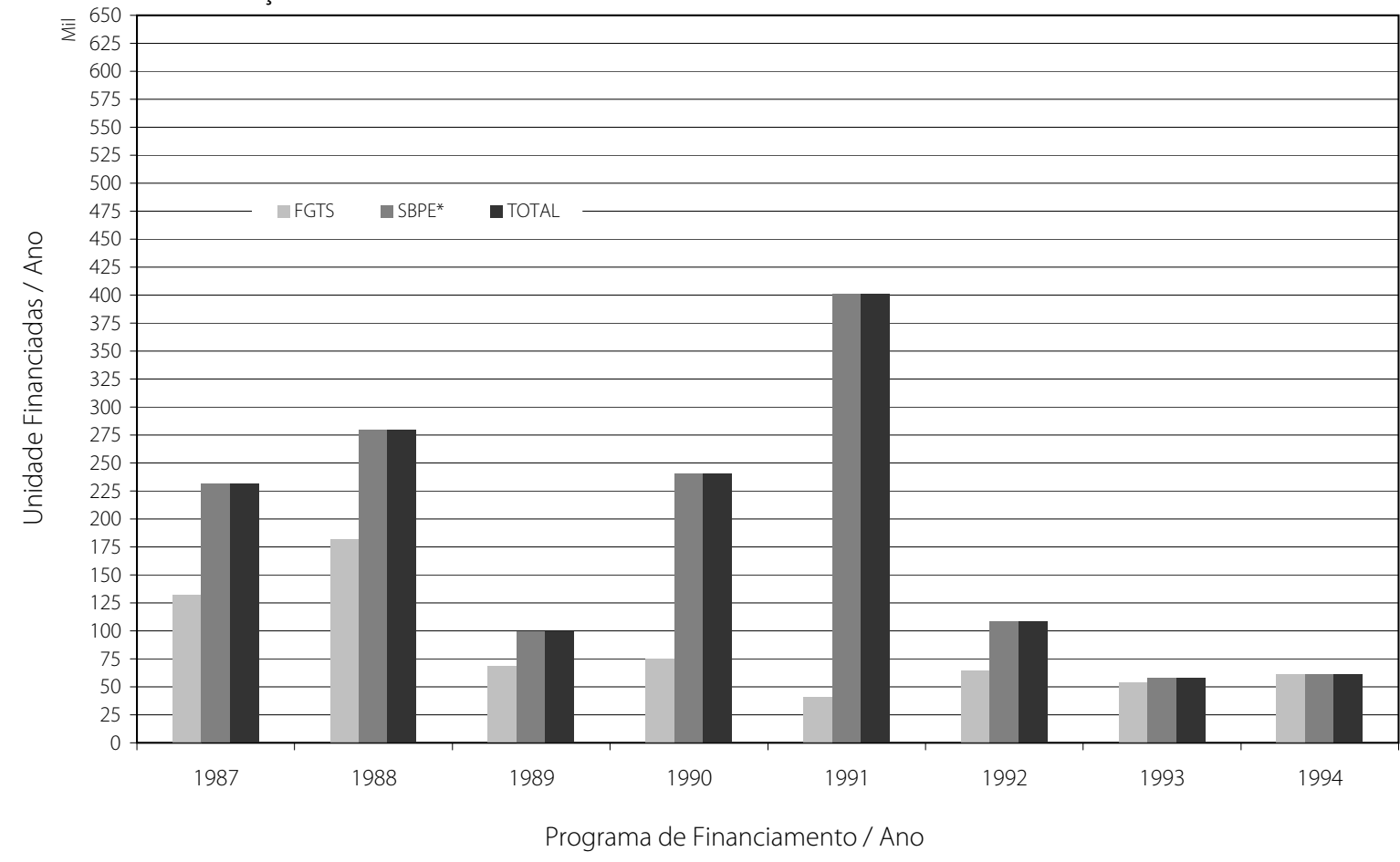

popular, que reuniu os programas de agentes promotores como COHABs e cooperativas (PROHAP), e o chamado Empresário Popular (PEP). Segundo Nahas, novas denominações para velhos programas (Carvalho; Branco Sobrinho, 1992). "A aplicação dos recursos do FGTS, em 1991, aponta para sua concentração nos programas produtores de unidades acabadas: PAIH, PEP, PROHAP (público e privado) e cooperativas absorveram 94,76\% do total de 432.142.924 UPF's contratadas"15.

A retomada das operações com recursos do FGTS em 1990 e 1991, depois de quase três anos sem contratações de porte, marca também o governo Collor. Cerca de 95\% do total de investimentos em habitação popular nesses dois anos foram feitos através do FGTS. No entanto, a maneira como foram efetuadas as liberações de verba e as contratações acabou objeto de uma CPMI, destinada a apurar irregularidades. E não foram poucas, pois se contrataram 526 mil unidades, 360 mil somente em 1991, volume que comprometeu o orçamento dos anos seguintes, impedindo a realização de novas operações. Essas unidades destinavam-se a objetivos políticos, e até hoje são conhecidas na CEF como empreendimentos-problema. No final de 1996, contabilizavam-se 75 empreendimentos, com 26.553 unidades com essas trole dos Programas Habitacionais PAIH/PEP/PROHAP/Cooperativas. Brasília: MAS, 1992. 
características (Souza, 1998). Havia uma discrepância entre a baixa qua-lidade das

habitações e a faixa de renda a quem se destinavam; muitas ficaram inacabadas e foram invadidas, por exemplo. Outras foram abandonadas ou permaneceram muito tempo sem ocupação por não terem uma demanda caracterizada, destinada a ocupá-las. Os motivos que levaram a isso foram vários, mas destacamos a má qualidade das habitações, a localização inadequada e os preços incompatíveis com a demanda que supostamente seria atendida (Freitas, 2002).

Uma das diferenças básicas que marcaram o período imediatamente subseqüente foi a instituição do financiamento direto à pessoa física e ao produtor. Além disso, os comitês técnicos, ou Câmaras Técnicas de Habitação, como ficaram conhecidas, foram vistos como um avanço, pois sua representação social era efetiva e constituíam um canal de diálogo importante com o governo federal. Houve uma retomada do controle público institucional sobre os recursos com a concomitante suspensão dos financiamentos do FGTS após o escandaloso episódio do governo Collor com o FGTS nos anos de 1990 e 1991.

O governo Itamar criou o Ministério do Bem-Estar Social, instituindo conselhos com participação comunitária e exigindo contrapartida financeira dos governos locais aos investimentos da União, com a intenção de melhorar o controle social e dar transparência à gestão administrativa. De qualquer forma, o investimento em valores e unidades habitacionais foi baixo em relação ao período anterior. Nesse mesmo propósito, em 1993, o CMN editou a Resolução CMN no. 1.980, que procurou disciplinar o direcionamento dos recursos captados pelas entidades integrantes do SBPE e as operações de financiamento efetuadas no âmbito do SFH, estabelecendo quem fazia parte do sistema e determinando regras e normas visando tornar mais clara as regras de funcionamento do mesmo.

Os principais programas do período foram Habitar-Brasil e Morar-Município, o primeiro para cidades de porte médio e grande e o último para pequenos municípios. Segundo o IPEA, serviram de base para a formulação de programas semelhantes, que continuaram inclusive na gestão Fernando Henrique Cardoso. 


\subsubsection{SFH}

No primeiro governo FHC, iniciado em 1995, a política habitacional ficou subordinada à Secretaria de Política Urbana do Ministério do Planejamento e Orçamento. E foi no âmbito dessa Secretaria que se iniciou uma revisão do uso dos recursos do SFH, especificamente do FGTS e dos recursos da caderneta de poupança como recursos fundamentais para subsidiar uma política nacional de habitação.

Em dois documentos oficiais, "Política Nacional de Habitação" (1996) e "Política de Habitação: Ações do Governo Federal de jan/95 a jun/98" (1998) o governo trata o SFH como "(i) esgotado - em virtude das crescentes dificuldades com a captação líquida das suas fontes de recursos (notadamente o FGTS); (ii) regressivo - por ter beneficiado principalmente as camadas de renda média e média alta com elevados subsídios implícitos pagos com recursos do erário; (iii) insuficiente - porque durante trinta anos produziu apenas 5,6 milhões do total de 31,6 milhões de novas moradias produzidas no país". Aponta ainda a excessiva centralização da gestão dos programas alternativos, bem como a falta de controle social, pelo fracasso do SFH.

A partir desse diagnóstico, foram desenvolvidos programas pela SEPURB, no Ministério de Planejamento e Orçamento, que podem ser divididos segundo sua fonte de recursos. O único programa financiado com o Orçamento Geral da União era o Habitar Brasil, criado no governo anterior. A maior parte dos programas foi financiada com recursos do FGTS, e se divide quanto aos tomadores do financiamento: Pró-Moradia e Pró-Saneamento para o setor público, Carta de Crédito Associativa e Carta de Crédito Individual, para pessoas físicas e associações, e Apoio à Produção, para o produtor.

O desenho institucional da política se mostrava atualizado com as análises técnicas e críticas baseadas no diagnóstico do SFH. Incorporou alguns avanços propostos a partir das câmaras setoriais e temáticas do final do governo Itamar que procurava 
integrar políticas urbanas e habitacionais (Maricato, 1998). No entanto, a distância

entre os documentos oficiais e os resultados demonstram que a política de ajuste fiscal feita a partir do Plano Real tornou a realização dos orçamentos iniciais do FGTS e mesmo do Orçamento Geral da União, ape-nas boas intenções. Segundo Maricato, "os números [...] divulgados não escondem o fracasso enquanto política social. O governo concentrou esforços no remanejo dos recursos onerosos e-xistentes, reduzindo a política habitacional a uma questão financeira e de mercado" (Maricato, 1998, p.76).

É interessante notar que já em 1996 os programas para o setor público Habitar-Brasil e Pró-Moradia foram os que tiveram menor número de contratações. Algumas das causas para esse mau desempenho podem ser atribuídas à baixa capacidade de pagamento do setor público e à falta de capacitação de estados e municípios. A principal delas, no entanto, foi o contingenciamento do setor público, que já se manifestava como conseqüência da política econômica do governo. O Consenso de Washington já causava estragos em outras áreas que demandavam investimento estatal e não seria diferente com a política habitacional, ainda mais suscetível ao ajuste fiscal conduzido pela política econômica do governo FHC.

A Resolução CMN no. 2.458, de 18 de dezembro de 1997, já apresenta os reflexos da política econômica no direcionamento dos recursos do SBPE. Dos 70\% destinados obrigatoriamente ao financiamento habitacional, apenas 30\% deveriam ser aplicados em operações no âmbito do SFH. O restante deveria ser aplicado em operações de faixa especial e faixa de mercado. Ainda assim, para a comprovação da exigibilidade, poderiam ser apresentadas pelas instituições integrantes do SBPE os créditos junto ao FCVS, o que as eximia, na prática de investir em novos financiamentos no montante exigido pela resolução.

Em relação ao desempenho do SFH para financiar a produção de novas unidades, a crítica feita por construtores não era animadora:

o quadro da época [a partir do Plano Real] era de inflação baixa com taxa de juros e-levada, o que penalizou o mutuário que passou a pagar uma prestação corrigida pela TR derivada de juro elevado [...] o resultado desse descompasso foi a inadimplência, que alcançou não apenas os mutuários, mas também as incorporadoras, 
amarradas a uma dívida atualizada por TR mais juros [...] as incorporadoras ven-

diam as unidades a longo prazo e recebiam as prestações corrigidas pelo IGPM e bancavam um financiamento atualizado pela TR, engordada pelos juros altos, uma situação insustentável16.

Essa descrição de reconhecido empresário do setor da construção civil expressa também o clima vigente nos anos 90 de desestímulo à atividade produtiva por conta da questão macroeconômica: "em vez de emprestar ao mutuário que precisava financiar a compra, os bancos passaram a financiar o governo pela compra de títulos públicos colocados no mercado com elevadas taxas de juro. Outra opção era o depósito de parcela que excedesse os 65\% de aplicação obrigatória em crédito imobiliário no Banco Central, obtendo remuneração idêntica à que era paga ao aplicador ${ }^{\prime \prime 1}$. Nesse contexto, com os recursos do SBPE sendo destinados a aplicações mais rentáveis, a promoção de unidades pelo SFH não foi significativa nos anos 90.

Esse cenário foi mudando com a estabilidade macroeconômica alcançada no final dos anos 90, ainda que sujeita a sérias crises, como a cambial em 1999. Com taxas de juros um pouco mais baixas, tanto o interesse de investidores pelo mercado da construção civil pareceu aumentar, como o interesse das instituições financeiras pela concessão de crédito de longo prazo deu sinais de que essa concessão poderia ser uma atividade lucrativa.

A partir de 2003, já com a estabilização econômica consolidada, o SFH passou por mudanças que levaram seus resultados a patamares iguais ou superiores aos anos de melhor desempenho quantitativo da época do BNH. Analisemos agora alguns resultados alcançados pelo SFH no SBPE e no FGTS.

16 Entrevista de Romeu Chap-Chap concedida à Tom Morooka na Revista do SFI. Ver Revista do SFI, ano 8, No. 18. São Paulo: ABECIP, 2004, p. 10.

$17 \quad$ Idem. 


\subsubsection{SBPE}

Já em 2003 nota-se uma mudança na curva de concessão dos financiamentos no âmbito do SFH, visto que houve um acréscimo de 25,43\% no valor nominal dos financiamentos concedidos e de $26,43 \%$ no número de unidades financiadas em relação ao ano anterior, $2002^{18}$.

Em relação ao SBPE, o gráfico abaixo indica claramente a proporção que o crédito imobi-liário tomou a partir de 2005, que é quando os resultados das mudanças institucionais puderam ser mensuradas. O gráfico apresenta os dados em quatro grandes agregações:

- Aquisição de imóveis novos: modalidade de financiamento que permite a aquisição de imóveis novos (com habite-se a no máximo 180 dias).

- Aquisição de imóveis usados: modalidade de financiamento que permite a aquisição de imóveis usados.

• Construção empresário: modalidade de financiamento à construção de novas unidades.

- Total financiado.

Os dados são apresentados para as faixas A, B e Taxa de Mercado até os anos 1997 e depois disso, faixas SFH e Taxa de Mercado. As faixas A e B, bem como a faixa SFH indicam imóveis financiados dentro das regras do SFH, ou seja, imóveis com limites pré-estabelecidos de valor total e financiamento, controlados por resoluções do Conselho Monetário Nacional. A faixa Taxa de Mercado indica imóveis financiados acima desses limites.

Em 2004 há a sinalização de que as mudanças no quadro normativo promovidas pelo novo governo estavam levando as contratações no âmbito do SFH a patamares que não eram vistos desde o período áureo do BNH, de 1979-82. Dessa forma, em 2004 os bancos fecharam 53.787 contratos de crédito imobiliário correspondentes a aproximadamente $\mathrm{R} \$ 3$ bilhões. Comparados com 2003, esses números apontam um aumento de 47,6\% no número de unidades financiadas e de 35,3\% no valor dos

18 BRASIL. Banco Central do Brasil. Sistema Financeiro da Habitação. Resumo Mensal do Setor -Dezembro de 2003. Disponível em <http://www.bcb.gov.br/fis/SFH/port/est2003/12/Resumo.pdf>. 
empréstimos. Comparados com 2002, há um aumento de 86,1\% no número de unidades e de 69,6\% no valor dos empréstimos.

Como podemos perceber, a partir de 2003 houve um aumento significativo de unidades financiadas, tanto no imóvel novo quanto no imóvel usado. No entanto, no imóvel usado (faixa SFH) o aumento foi de aproximadamente 10 vezes em 6 anos (2003-2008), o que nos leva a concluir que de fato havia uma demanda reprimida por crédito no segmento residencial para o estoque existente de habitação. A construção de novas unidades, no âmbito do SFH, teve um aumento ainda mais espetacular, saltando de 14.088 para 140.164 contratos em um período de 6 anos (2003-2008).

Em 2007 e 2008 as contratações com recursos do SBPE atingiram um ápice que ficou conhecido como o recente boom imobiliário, com números muito expressivos que devem, de fato, boa parte de seu resultado a uma atuação do governo federal principalmente em dois âmbitos:

- Melhoria do ambiente regulatório resultando em uma maior segurança jurídica para incorporadores, construtores, e investidores, o que impacta no aumento do número de construções financiadas. A adoção em 2004 da garantia alienação fiduciária de bem imóvel pode ser considerada uma dessas medidas.

- Melhoria do crédito para a pessoa física com mudança de taxas de juros, prazos e valor de entrada (menor poupança prévia): ampliação da quota de financiamento de imóveis usados de 70\% para 90\% e prazos de até 30 anos.

Importante salientar que essa melhoria do crédito se deve também à queda da taxa referencial de juros da economia, taxa Selic, reforçando o aspecto macroeconômico do financiamento habitacional, financiamento de longo prazo, completamente influenciado pelos números gerais do desempenho econômico do país.

Em 2008, os dados do SBPE apontam para o ápice dos números do boom imobiliário. Um total de $\mathrm{R} \$ 2$ 29.008.520.223,00 em financiamentos residenciais concedidos, com 294.817 unidades habitacionais (o total de financiamentos imobiliários é de 298.496 unidades e R\$29.996.176.774,00 concedidos, considerando-se os imóveis comerciais) São quase 10 vezes mais unidades habitacionais financiadas do que no 
TABELA 5

SBPE: Financiamento para aquisição de Imóvel Novo, Aquisição de Imóvel Usado e Construção de Unidades Habitacionais - 1994 a 2008

\begin{tabular}{|c|c|c|c|c|c|c|c|c|c|}
\hline \multirow{3}{*}{ Ano } & \multirow{3}{*}{ Renda } & \multicolumn{4}{|c|}{ Aquisição } & \multirow{2}{*}{\multicolumn{2}{|c|}{ Construção - Empresário }} & \multirow{2}{*}{\multicolumn{2}{|c|}{ TOTAL }} \\
\hline & & \multicolumn{2}{|r|}{ Imóvel Novo } & \multicolumn{2}{|r|}{ Imóvel Usado } & & & & \\
\hline & & Unidades & Valores & Unidades & Valores & Unidades & Valores & Unidades & Valores \\
\hline \multirow{3}{*}{1994} & $A$ & 1.141 & $\mathrm{R} \$ 15.456 .398,00$ & 2.021 & $R \$ 25.186 .854,00$ & 4.303 & $R \$ 62.255 .859,00$ & 7.788 & $\mathrm{R} \$ 101.747 .335,00$ \\
\hline & B & 10.118 & $R \$ 281.435 .402,00$ & 6.277 & R\$ $181.334 .815,00$ & 28.804 & $\mathrm{R} \$ 813.186 .758,00$ & 47.583 & R\$ 1.350.997.937,00 \\
\hline & TM & 1.012 & $R \$ 56.958 .765,00$ & 1.048 & R\$ 51.259.239,00 & 3.748 & R\$ $165.145 .343,00$ & 6.013 & $\mathrm{R} \$ 282.650 .354,00$ \\
\hline \multicolumn{8}{|r|}{ Total 1994} & 61.384 & $\mathrm{R} \$ 1.735 .395 .626,00$ \\
\hline \multirow{3}{*}{1995} & A & 1.456 & $R \$ 27.122 .127,00$ & 2.748 & $R \$ 47.257 .748,00$ & 4.580 & $R \$ 89.198 .004,00$ & 8.913 & $R \$ 165.601 .963,00$ \\
\hline & B & 10.875 & $\mathrm{R} \$ 458.023 .571,00$ & 6.885 & $\mathrm{R} \$ 282.307 .677,00$ & 15.286 & $\mathrm{R} \$ 595.719 .885,00$ & 33.338 & $R \$ 1.348 .652 .611,00$ \\
\hline & TM & 1.457 & $\mathrm{R} \$ 126.605 .498,00$ & 1.011 & $\mathrm{R} \$ 103.927 .069,00$ & 1.721 & $\mathrm{R} \$ 116.689 .634,00$ & 4.309 & $\mathrm{R} \$ 356.699 .499,00$ \\
\hline \multicolumn{8}{|r|}{ Total 1995} & 46.560 & R\$ 1.870.954.073,00 \\
\hline \multirow{3}{*}{1996} & A & 1.159 & $\mathrm{R} \$ 18.995 .230,00$ & 1.546 & $R \$ 26.601 .644,00$ & 8.055 & $\mathrm{R} \$ 92.489 .765,00$ & 10.956 & $\mathrm{R} \$ 141.069 .815,00$ \\
\hline & B & 8.486 & $\mathrm{R} \$ 398.842 .120,00$ & 3.971 & $\mathrm{R} \$ 166.070 .906,00$ & 11.379 & $\mathrm{R} \$ 454.176 .958,00$ & 23.999 & R\$ $1.026 .842 .643,00$ \\
\hline & TM & 1.067 & $\mathrm{R} \$ 101.242 .721,00$ & 618 & R\$ 52.227.569,00 & 1.202 & $\mathrm{R} \$ 103.768 .126,00$ & 3.331 & $\mathrm{R} \$ 294.763 .830,00$ \\
\hline \multicolumn{8}{|r|}{ Total 1996} & 38.286 & $\mathrm{R} \$ 1.462 .676 .288,00$ \\
\hline \multirow{3}{*}{1997} & A & 563 & $R \$ 8.663 .755,00$ & 890 & $\mathrm{R} \$ 16.018 .837,00$ & 2.975 & $\mathrm{R} \$ 58.288 .764,00$ & 4.874 & $\mathrm{R} \$ 86.246 .027,00$ \\
\hline & B & 5.957 & $\mathrm{R} \$ 298.491 .082,00$ & 5.531 & $\mathrm{R} \$ 252.617 .819,00$ & 12.127 & $\mathrm{R} \$ 528.130 .232,00$ & 23.899 & $\mathrm{R} \$ 1.089 .347 .144,00$ \\
\hline & TM & 1.557 & $\mathrm{R} \$ 169.387 .154,00$ & 1.433 & $\mathrm{R} \$ 122.926 .304,00$ & 3.354 & $\mathrm{R} \$ 228.722 .805,00$ & 6.714 & $\mathrm{R} \$ 549.013 .177,00$ \\
\hline \multicolumn{8}{|r|}{ Total 1997} & 35.487 & R\$ $1.724 .606 .348,00$ \\
\hline \multirow{2}{*}{1998} & SFH & 6.168 & $\mathrm{R} \$ 285.511 .543,00$ & 7.733 & $\mathrm{R} \$ 327.686 .287,00$ & 16.537 & $R \$ 775.789 .288,00$ & 30.801 & $R \$ 1.397 .507 .958,00$ \\
\hline & TM & 2.160 & $\mathrm{R} \$ 196.985 .790,00$ & 1.902 & $\mathrm{R} \$ 166.000 .011,00$ & 3.524 & $\mathrm{R} \$ 283.116 .386,00$ & 7.974 & $\mathrm{R} \$ 678.767 .823,00$ \\
\hline \multicolumn{8}{|r|}{ Total 1998} & 38.887 & R\$ 2.083.623.117,00 \\
\hline \multirow{2}{*}{1999} & SFH & 7.724 & $R \$ 352.036 .670,00$ & 8.639 & $R \$ 347.019 .705,00$ & 12.549 & $R \$ 424.104 .709,00$ & 29.714 & $R \$ 1.149 .955 .972,00$ \\
\hline & TM & 1.127 & $\mathrm{R} \$ 114.471 .702,00$ & 716 & $\mathrm{R} \$ 85.303 .004,00$ & 2.888 & $R \$ 296.051 .101,00$ & 4.880 & $\mathrm{R} \$ 508.748 .155,00$ \\
\hline \multicolumn{8}{|r|}{ Total 1999} & 35.549 & $\mathrm{R} \$ \mathbf{1 . 6 9 5 . 5 6 8 . 9 3 1 , 0 0}$ \\
\hline 2000 & SFH & 6.732 & $\mathrm{R} \$ 296.253 .814,00$ & 9.517 & $\mathrm{R} \$ 409.794 .271,00$ & 9.920 & $R \$ 396.797 .053,00$ & 26.708 & $R \$ 1.122 .679 .253,00$ \\
\hline 2000 & TM & 857 & $\mathrm{R} \$ 99.022 .905,00$ & 478 & R\$ $64.169 .008,00$ & 7.217 & R\$ 571.091.290,00 & 8.951 & $\mathrm{R} \$ 762.663 .433,00$ \\
\hline & & & & & & & Total 2000 & 36.333 & $\mathrm{R} \$ 1.909 .848 .517,00$ \\
\hline 2001 & SFH & 6.210 & $\mathrm{R} \$ 344.878 .349,00$ & 13.377 & $\mathrm{R} \$ 697.232 .336,00$ & 12.458 & $\mathrm{R} \$ 482.102 .368,00$ & 32.300 & R\$ $1.537 .573 .137,00$ \\
\hline 2001 & TM & 363 & $\mathrm{R} \$ 62.444 .233,00$ & 596 & $\mathrm{R} \$ 94.899 .201,00$ & 2.178 & $\mathrm{R} \$ 139.686 .062,00$ & 3.274 & $\mathrm{R} \$ 313.256 .586,00$ \\
\hline & & & & & & & Total 2001 & 35.756 & $\mathrm{R} \$ 1.870 .213 .292,00$ \\
\hline ברקב & $\mathrm{SFH}$ & 6.619 & $\mathrm{R} \$ 409.485 .248,00$ & 10.487 & $\mathrm{R} \$ 580.265 .072,00$ & 8.115 & $R \$ 401.911 .322,00$ & 25.519 & $\mathrm{R} \$ 1.404 .925 .762,00$ \\
\hline 2002 & TM & 466 & $R \$ 76.301 .383,00$ & 946 & $\mathrm{R} \$ 93.379 .147,00$ & 1.790 & $\mathrm{R} \$ 154.645 .066,00$ & 3.271 & $\mathrm{R} \$ 331.100 .201,00$ \\
\hline & & & & & & & Total 2002 & 28.902 & $\mathrm{R} \$ 1.768 .458 .956,00$ \\
\hline 2003 & SFH & 6.173 & $\mathrm{R} \$ 412.279 .065,00$ & 11.947 & $\mathrm{R} \$ 630.843 .184,00$ & 14.088 & $R \$ 696.052 .669,00$ & 32.588 & $\mathrm{R} \$ 1.765 .449 .081,00$ \\
\hline 2003 & TM & 850 & $\mathrm{R} \$ 90.125 .939,00$ & 646 & $\mathrm{R} \$ 81.176 .518,00$ & 2.141 & R\$ 230.536.463,00 & 3.788 & $\mathrm{R} \$ 412.132 .692,00$ \\
\hline & & & & & & & Total 2003 & 36.446 & R\$ 2.216.736.443,00 \\
\hline 2004 & SFH & 13.905 & $R \$ 659.075 .985$ & 13.247 & $R \$ 701.472 .138$ & 21.315 & $R \$ 1.264 .216 .284$ & 51.081 & $R \$ 2.676 .856 .227,00$ \\
\hline 2004 & TM & 1.204 & $\mathrm{R} \$ 147.352 .622$ & 451 & $\mathrm{R} \$ 81.268 .280$ & 594 & $\mathrm{R} \$ 52.899 .419$ & 2.352 & R\$ 294.273.114,00 \\
\hline & & & & & & & Total 2004 & 53.786 & R\$ 3.000.187.906,00 \\
\hline & SFH & 7.252 & $\mathrm{R} \$ 585.422 .305,00$ & 17.709 & $R \$ 1.104 .649 .523,00$ & 32.871 & $R \$ 2.542 .877 .601,00$ & 58.336 & $\mathrm{R} \$ 4.261 .206 .989,00$ \\
\hline 2005 & TM & 841 & $\mathrm{R} \$ 127.942 .556,00$ & 482 & R\$ 98.886.592,00 & 125 & $\mathrm{R} \$ 65.474 .051,00$ & 1.536 & $\mathrm{R} \$ 303.044 .959,00$ \\
\hline & & & & & & & Total 2005 & 60.768 & $\mathrm{R} \$ 4.792 .698 .865,00$ \\
\hline & SFH & 11.935 & $\mathrm{R} \$ 919.092 .926,00$ & 54.904 & $R \$ 3.558 .950 .403,00$ & 37.992 & $R \$ 3.971 .984 .589,00$ & 109.289 & $\mathrm{R} \$ 8.703 .271 .595,00$ \\
\hline 2006 & TM & 744 & $\mathrm{R} \$ 174.068 .451,00$ & 762 & R\$ $188.073 .108,00$ & 396 & $R \$ 92.665 .034,00$ & 2.007 & $\mathrm{R} \$ 473.531 .452,00$ \\
\hline & & & & & & & Total 2006 & 111.988 & $\mathrm{R} \$ 9.314 .060 .279,00$ \\
\hline & SFH & 17.455 & $R \$ 1.427 .771 .008,00$ & 84.009 & $R \$ 6.112 .942 .039,00$ & 77.110 & $R \$ 7.924 .813 .508,00$ & 186.562 & $R \$ 15.984 .182 .827,00$ \\
\hline 2007 & TM & 3.693 & $\mathrm{R} \$ 663.237 .634,00$ & 1.587 & $\mathrm{R} \$ 417.847 .890,00$ & 1.341 & $\mathrm{R} \$ 485.731 .601,00$ & 6.985 & $\mathrm{R} \$ 1.637 .567 .227,00$ \\
\hline & & & & & & & Total 2007 & 194.853 & R\$ 18.252.529.599,00 \\
\hline 2 & SFH & 28.050 & $\mathrm{R} \$ 2.724 .327 .769,00$ & 101.107 & $R \$ 8.839 .868 .178,00$ & 140.164 & $\mathrm{R} \$ 13.232 .726 .721,00$ & 279.526 & $\mathrm{R} \$ 25.556 .984 .120,00$ \\
\hline 2008 & TM & 4.612 & $\mathrm{R} \$ 1.078 .905 .475,00$ & 2.928 & $\mathrm{R} \$ 973.223 .982,00$ & 7.191 & $\mathrm{R} \$ 1.257 .646 .032,00$ & 15.291 & $\mathrm{R} \$ 3.451 .536 .103,00$ \\
\hline
\end{tabular}

Fonte: BACEN, Estatísticas Básicas do SFH.

ano de 2002, ou ainda, em um único ano alcançou-se toda a produção de 1995 a 2002. Esse desempenho numérico justifica a designação de boom, pois se trata de uma reversão significativa de tendência do SBPE durante os anos 90. É o maior número anual de financiamentos do SBPE na história do SFH, superando inclusive o número recorde de 1981. 
SBPE: Evolução do financiamento de unidades habitacionais entre 1994 e 2008.

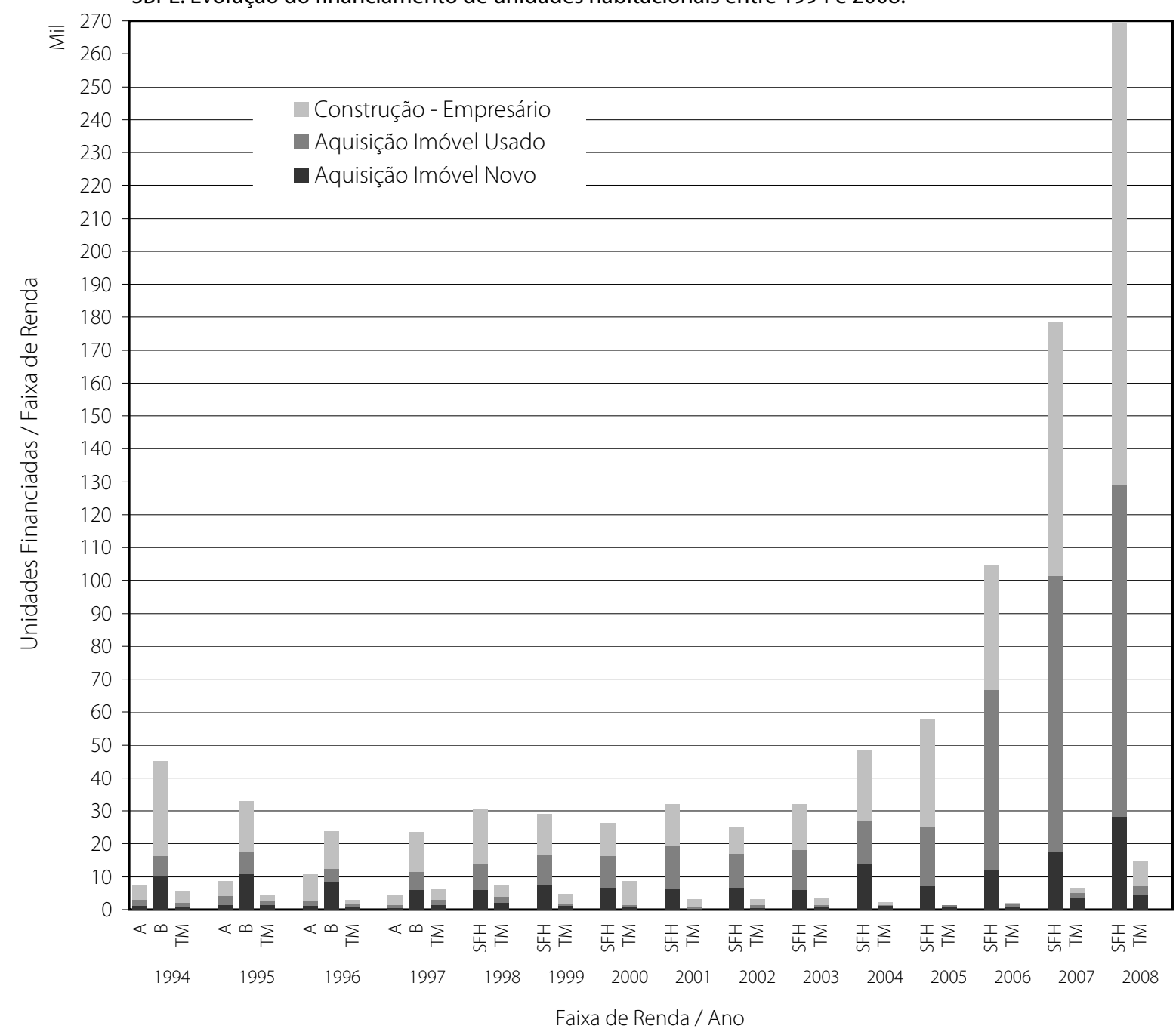

Destes números de 2008 importa ressaltar que mais de 13 bilhões foram destinados a financiar construção de imóveis novos no plano empresário, produzindo 140.164 unidades habitacionais dentro da faixa do SFH, a uma média de $\mathrm{R} \$ 94.408,00$ por financiamento. Considerando-se que os financiamentos no âmbito do SFH atingem aproximadamente $90 \%$ do valor do imóvel, temos que essa produção teve seu foco em imóveis de $\mathrm{R} \$ 100.000,00$ a $\mathrm{R} \$ 110.000,00$. Como estamos trabalhando com valores médios mês a mês somados, com média tirada pela somatória anual, certamente há variação nesses valores, o que não invalida a análise de que essa produção atingiu imóveis destinados a faixa de renda de aproximadamente 07 a 08 salários mínimos.

Nessa mesma modalidade, mas no âmbito da Taxa de Mercado, a construção de 


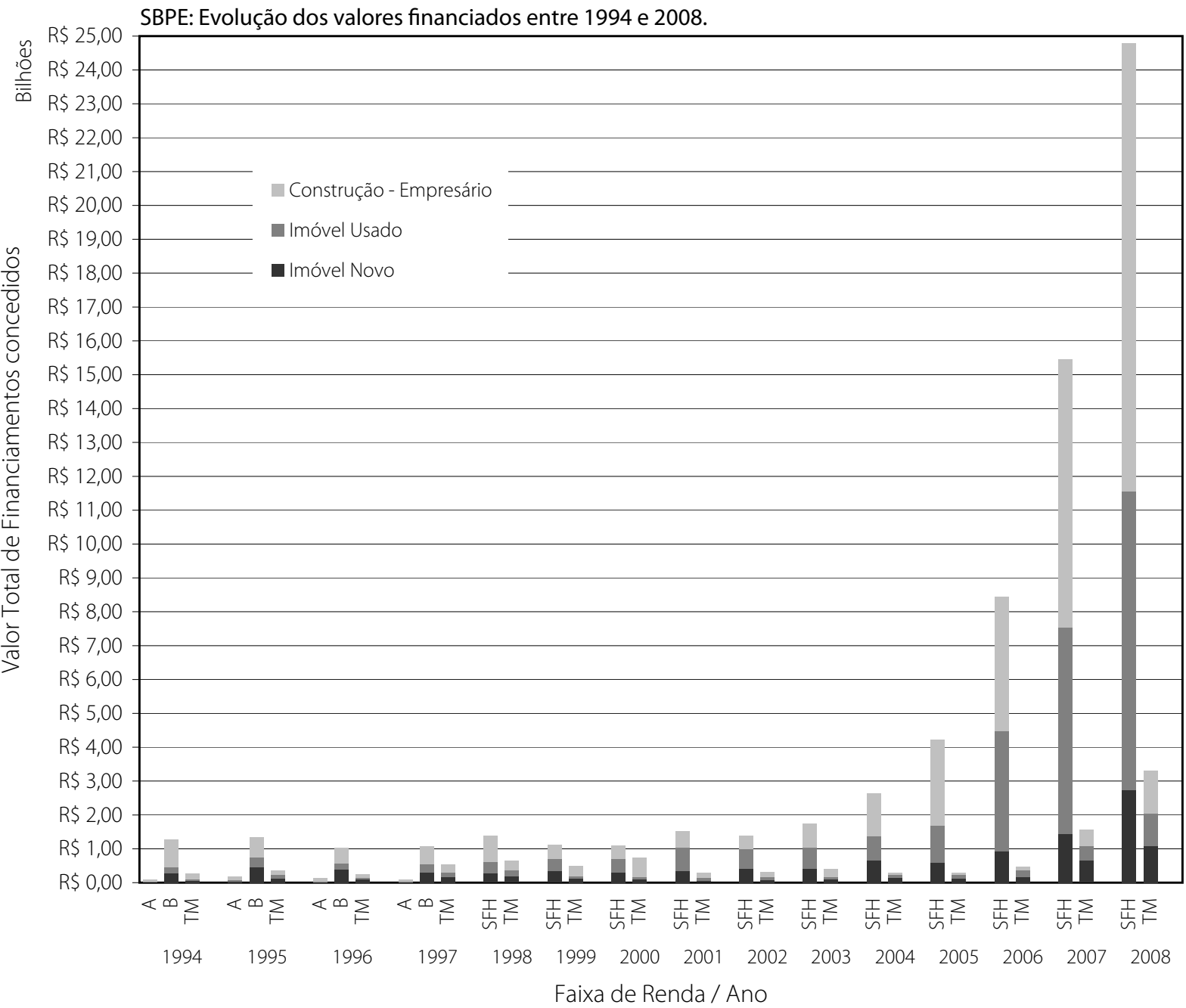

imóveis novos no plano empresário, foram financiadas 7.191 unidades habitacionais no ano de 2008, perfazendo $\mathrm{R} \$ 1.257 .646 .032,00$, uma média de $\mathrm{R} \$ 174.891,67$ por unidade.

O volume de financiamentos destinados a aquisição de imóveis usados impressiona, visto que para essa modalidade foram utilizados quase 9 bilhões de reais no ano de 2008, R\$ 8.839.868.178,00, dentro do SFH, destinados a 101.107 unidades, perfazendo uma média de $\mathrm{R} \$ \mathbf{8 7 . 4 3 0 , 0 0}$ por unidade. Para aquisições de imóveis usados dentro da faixa taxa de mercado, essa média vai a $\mathrm{R} \$ 332.385,24$, visto que foram financiadas 2.928 unidades com um recurso de R\$ 973.223.982,00.

A curva de aquisição de imóveis usados de fato indica uma demanda reprimida por crédito para que esses imóveis pudessem fazer parte de uma oferta solvável. 
SBPE: Evolução do número de financiamentos concedidos para aquisição de imóveis novos entre 1994 e 2008.

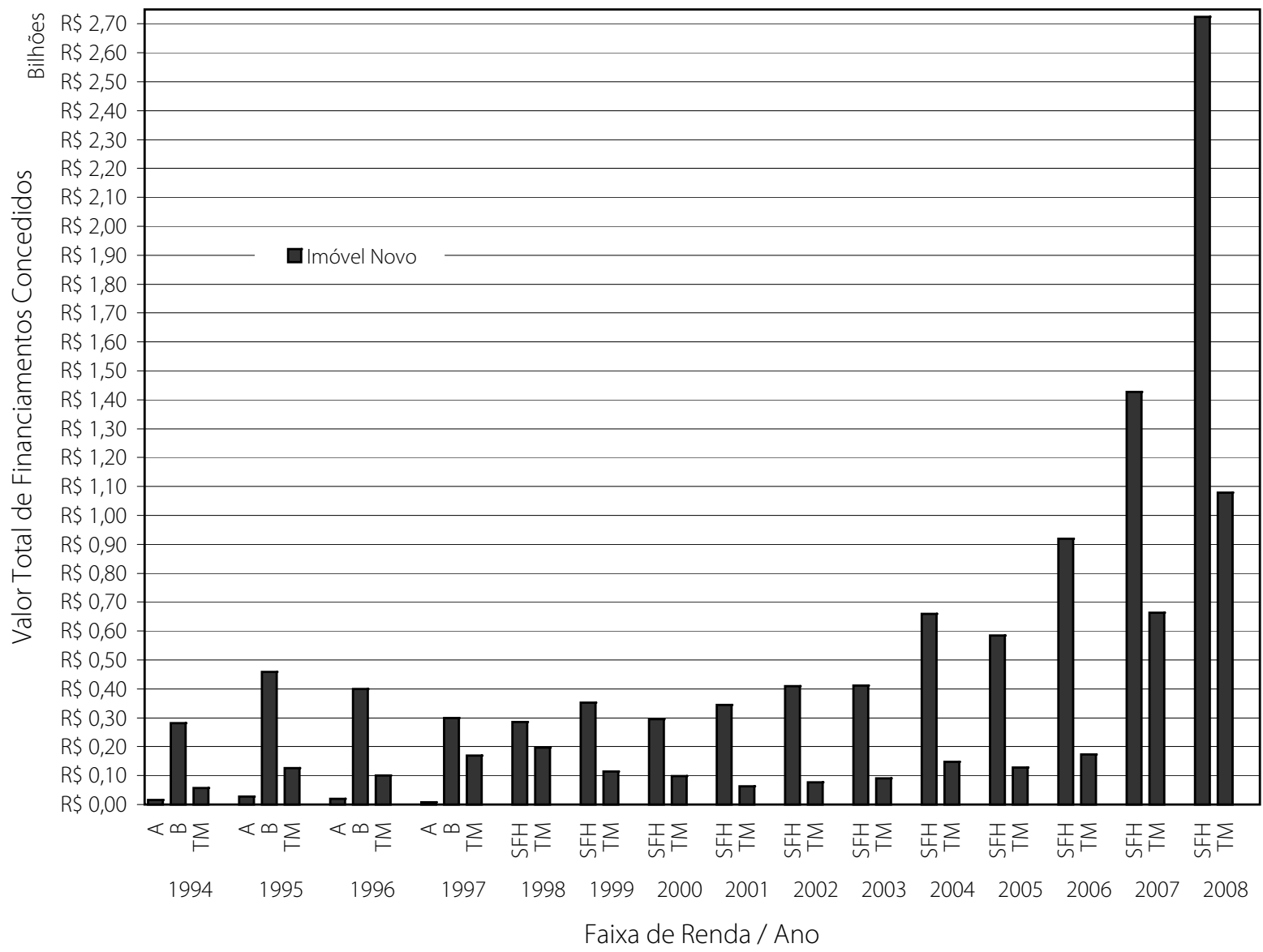

Do ponto de vista urbanístico, a aquisição de imóveis usados faz com que imóveis localizados em áreas infra-estruturadas não restem vazios, otimizando a ocupação do espaço urbano. No entanto, essa modalidade não tem a simpatia de setores da construção civil, especialmente dos sindicatos patronais ligados a construção civil com assento no Conselho Curador ${ }^{19}$ pois se argumenta que esses recursos não produzem os mesmos efeitos positivos na economia do país que seriam gerados pela produção de novas unidades.

A evolução da aquisição de imóveis usados foi muito significativa entre 2003 e 2008: mais de 746\% em seis anos no âmbito do SFH. Sob qualquer aspecto analisado, os números são muito expressivos, indicando um grande mercado reprimido que teve seu equacionamento com a melhoria do ambiente macroeconômico e com 
SBPE: Evolução do número de financiamentos concedidos para aquisição de imóveis usados entre 1994 e 2008.

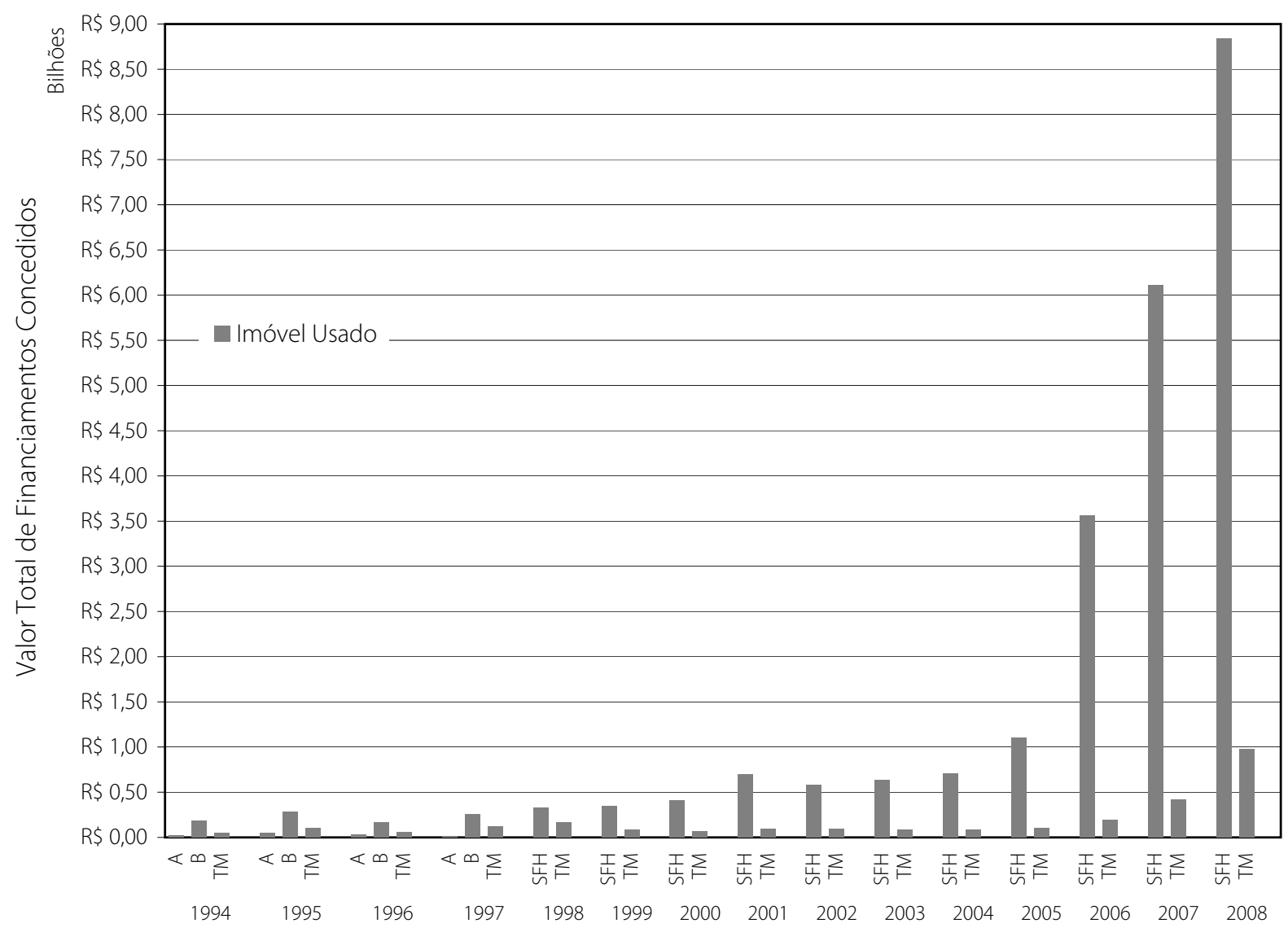

Faixa de Renda / Ano

a melhoria das condições do crédito para longo prazo, especialmente do crédito habitacional.

Ainda que possamos atribuir à melhoria do ambiente regulatório as significativas melhoras no desempenho do crédito imobiliário destinado à construção, a espetacular melhora no desempenho do crédito a imóveis usados se deve basicamente à melhoria das condições objetivas na tomada desse crédito, ou seja, diminuiç̧ão de taxas de juros, aumento de prazo, melhoria na análise de risco de crédito. São medidas que, impulsionadas pelo ambiente de estabilidade macroeconômica, fizeram do crédito imobiliário um produto de prateleira dos grandes bancos com o intuito de fidelizar os clientes por longos períodos.

Já os valores de financiamento a imóveis novos corresponderam em 2008 a aproximadamente 30,8\% dos valores destinados a aquisição de imóveis usados. Essa 
mesma relação indicava um percentual de 65,4\% em 2003. Desde 2000 o financia-

mento para aquisição de imóveis usados é bem maior do que o financiamento para aquisição de imóveis novos. Isso aponta uma tendência de que o parque residencial construído está movimentando o crédito do SBPE de forma significativa (ver Gráfico $6)$.

No entanto, no período de 2003 a 2008, houve um aumento de aproximadamente 354\% no número de financiamentos para a aquisição de imóveis novos destinados a pessoas físicas sob as condições do SFH. É um aumento muito significativo, considerando-se especialmente que durante o período de 1995 a 2002 verificou-se uma redução da ordem de 46,3\% no número de unidades financiadas. O número tende a indicar a existência de um grande mercado de crédito destinado a financiar esse tipo de demanda. Se considerarmos os imóveis financiados a taxa de mercado, ou seja, com taxas de juros superiores a $12 \%$ ao ano, esse aumento vai a $442,6 \%$ no mesmo período, indicando que mesmo para taxas de juros mais altas, o funding da caderneta de poupança constitui um mercado importante para instituições financeiras. Ainda que em termos absolutos o número financiado em 6 anos sob essa modalidade não pareça expressivo, 84.770 unidades no âmbito do SFH e 11.944 a taxa de mercado, seu crescimento relativo indica uma tendência importante.

Também a construção de unidades novas por meio do plano empresário sofreu um aumento expressivo ano a ano. De 2003 a 2004 houve um aumento de 65,5\%; de 2004 a 2005, um aumento de 54,2\%; de 2005 a 2006, aumento de 15,6\%. Os anos de 2006 e 2007 foram os que registraram um enorme crescimento dessa modalidade: neste intervalo, houve um crescimento de quase 103\%, ou seja, mais do que dobrou o financiamento à construção de novas unidades no âmbito do SFH. Por fim, de 2007 a 2008, houve um crescimento de quase 82\%. Se considerarmos a série de 2003 a 2008, houve um aumento de aproximadamente 895\% no financiamento à construção de novas unidades. Esses números mostram um patamar diferenciado e evidenciam com clareza o boom imobiliário para esse tipo de imóvel. Pode-se observar também pelo gráfico abaixo a elevação do número de financiamentos para a faixa Taxa de Mercado. Mas o crescimento expressivo de construção de novas unidades no SBPE se deu mesmo na faixa de imóveis que se encontram dentro do SFH, 
com limite de financiamento de até R\$ 245 mil e valor do imóvel não superior a R\$

350 mil20. O funding para essa transformação não foi outro que não o SBPE, ou seja, a caderneta de poupança.

A Resolução CMN nº. 3.005, de 30 de julho de 2002, também contribuiu para a ampliação dos recursos da caderneta de poupança destinada para financiamento imobiliário, não por alterar as regras da exigibilidade, mas sim por diminuir a quantidade de créditos do FCVS que poderiam ser computados na exigibilidade.

GRÁFICO 7

SBPE: Evolução do número de financiamentos concedidos para construção de unidades novas entre 1994 e 2008.

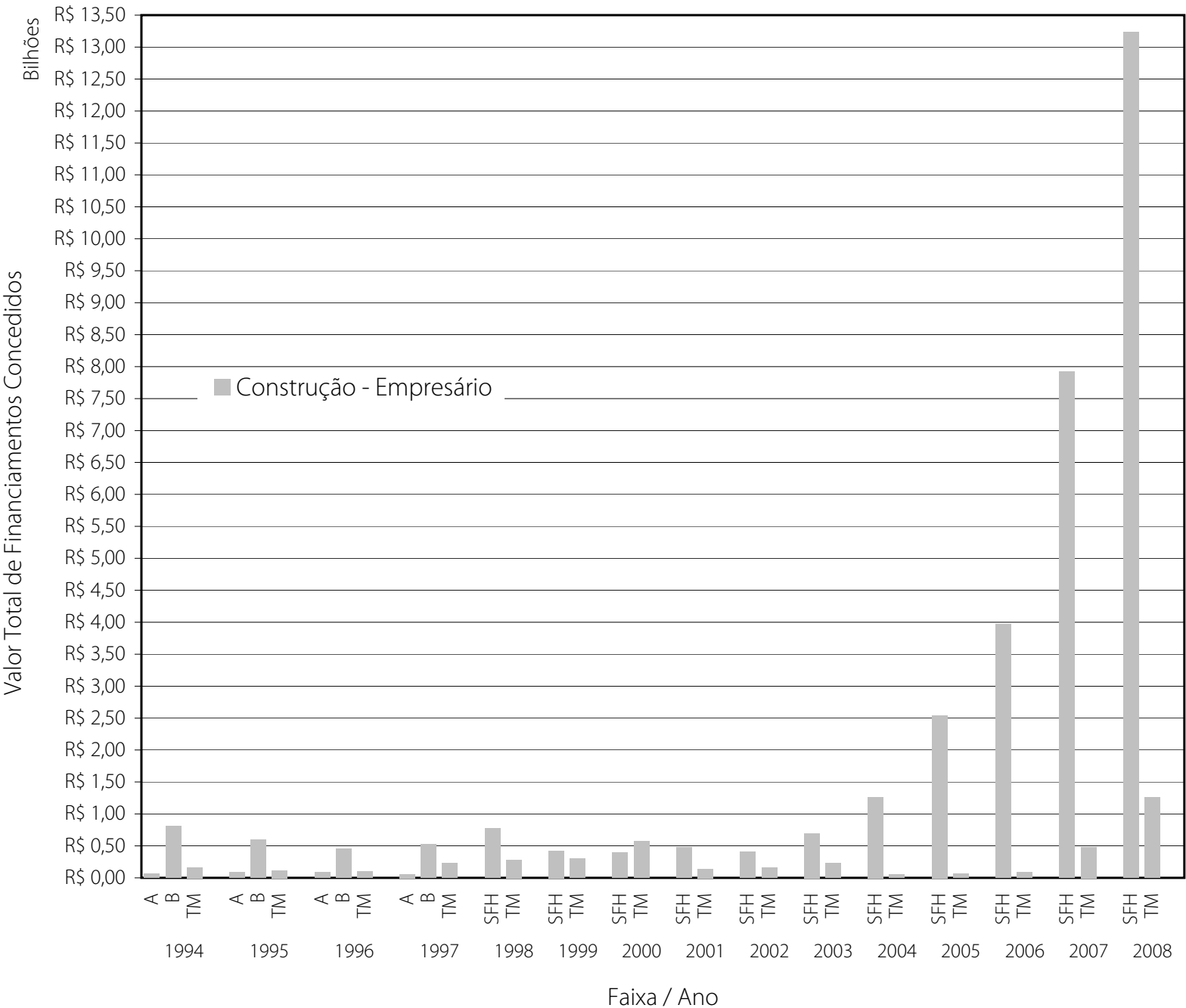

20 A partir de março de 2009, por meio da Resolução CMN n 3.706, os valores limites do SFH foram alterados, subindo o limite de financiamento até R\$ 450 mil e valor do imóvel até R\$500 mil. No entanto, no auge do boom imobiliário os valores eram os apontados no texto acima, $\mathrm{R} \$ 245$ mil para financiamento e $\mathrm{R} \$ 350$ mil para valor do imóvel. Visto que o sistema funciona quase sempre atingindo os valores limite, fica a dúvida se o boom teria acontecido no volume observado nos anos de 2007 e 2008 se os limites do SFH já tivessem sido majorados. 
Após sete anos da lei que permitiu por meio do PROER ${ }^{21}$ que houvesse emissão de

títulos a favor de bancos que detinham contratos cobertos pelo FCVS, a referida Resolução iniciou a 'retirada' desses títulos da contabilização da exigibilidade. Esses títulos emitidos pelo governo eram contabilizados na exigibilidade dos recursos da poupança, reduzindo os recursos destinados à construção de novos empreendimentos.

\subsubsection{Direcionamento dos recursos da poupança}

Como já foi salientado anteriormente, é previsto pelo Conselho Monetário Nacional um direcionamento dos recursos da poupança. Nesse direcionamento há uma exigência de que um percentual desses recursos seja destinado a financiamento imobiliário. Atualmente essa norma é exarada por meio da Resolução CMN n³.347.

Especificamente na questão do direcionamento dos recursos da poupança e da exigibilidade de aplicação desses recursos direcionados, é importante atentar para algumas mudanças recentes que deram impulso no volume de crédito concedido no âmbito do SFH.

A partir de 1995, com a edição do PROER, algumas instituições financeiras foram autorizadas a vender seus créditos do FCVS junto à União, com um deságio de 50\%, para bancos em liquidação, que com isso conseguiram resultados financeiros melhores em seus balanços. Por terem aceitado vender seus créditos com esse deságio de 50\%, os bancos que participaram desse acordo tiveram autorização para continuar contabilizando integralmente os créditos do FCVS que detinham antes da venda para fins de cálculo da exigibilidade da poupança. Dessa forma, essas instituições financeiras, que já tinham recebido 50\% dos créditos do FCVS, puderam continuar contabilizando integralmente créditos pelos quais elas já ti-nham recebido. Esse mecanismo contábil ficou conhecido como 'FCVS Virtual'e desde 1995 ocupa espaço considerável no direcionamento de recursos da poupança.

A partir de 2002, com a Resolução CMN no. 3.005, esses créditos virtuais foram paulatinamente sendo excluídos do cômputo da exigibilidade, em 100 meses, 1\% ao mês.

21 PROER - Programa de Estímulo à Reestruturação e ao Fortalecimento do Sistema Financeiro Nacional 
Dessa forma, as instituições financeiras deveriam aplicar efetivamente em financiamentos imobiliários esses recursos, o que injetou, à época, aproximadamente 200 milhões de reais por mês no mercado imobi-liário. Essa Resolução foi um dos desdobramentos da lei 10.150, de 21 de dezembro de 2000, que procurou disciplinar e equacionar as dívidas do Fundo de Compensação de Variações Salariais - FCVS, relativas a saldos devedores remanescentes da liquidação de contratos de financiamento, firmados com mutuários finais do SFH, junto às instituições financeiras.

A Tabela 6 apresenta os dados do direcionamento de recursos da poupança. Notase que os créditos destinados ao FCVS estavam consumindo os recursos que poderiam ir para o financiamento da produção de novas unidades ou mesmo à aquisição de imóveis novos e usados. Os créditos junto ao FCVS representavam em 2000, por exemplo, 30\% a mais do que valor de financiamentos habitacionais, imobiliários e à taxa de mercado somados. Representava, portanto, 52\% do total de aplicações imobiliárias do direcionamento dos recursos da poupança.

Em 2002, já sob a vigência da Resolução CMN nº 3.005, fica clara a leitura dos créditos virtuais que são computados separadamente (ver coluna FCVS Art. 1 e 2 Resolucao 334722) dos créditos existentes, 'reais', do FCVS. Ainda assim, os créditos 'reais' do FCVS são muito significativos, representando sozinhos $24 \%$ a mais do que os recursos destinados a financiamentos habitacionais.

O cômputo dos créditos 'virtuais' do FCVS está caindo ano a ano e já não tem representatividade na composição do direcionamento dos recursos. No entanto, os créditos 'reais' do FCVS continuam compondo uma parcela significativa do direcionamento dos recursos da poupança sem, no entanto, representar percentual maior do que os recursos aplicados em financiamento. Essa reversão na tendência do direcionamento dos recursos se deu a partir de 2005 e pode ser compreendida pelo aumento do número de financiamentos imobi-liários que ocorreu a partir de 2004 (ver Tabela 6).

Os recursos oriundos da poupança que não são efetivamente aplicados no finan-

22 Como já foi colocado, a Resolução CMN no. 3.347 é a resolução atualmente vigente, que deu lugar à Resolução CMN n 3.005 nas regras referentes ao direcionamento dos recursos da poupança. 
Direcionamento dos recursos da poupança - Usos.

\begin{tabular}{|c|c|c|c|c|c|c|c|c|c|}
\hline \multirow[b]{3}{*}{ Mês |Ano } & \multicolumn{9}{|c|}{ USOS } \\
\hline & \multicolumn{7}{|c|}{ Aplicaçōes Imobiliárias } & \multirow[b]{2}{*}{$\begin{array}{l}\text { Compuls. } \\
\text { BACEN }\end{array}$} & \multirow[b]{2}{*}{ Total de usos } \\
\hline & $\begin{array}{l}\text { Financiam. } \\
\text { Habitacionais (1) }\end{array}$ & $\begin{array}{l}\text { Financiam. } \\
\text { Imobiliários a } \\
\text { T.M. (2) }\end{array}$ & $\begin{array}{l}\text { Créditos Junto } \\
\text { ao FCVS e } \\
\text { Divida }\end{array}$ & $\begin{array}{c}\text { FCVS (3) } \\
\text { Art. } 1 \text { e } 2 \\
\text { Resolução } \\
3347\end{array}$ & $\begin{array}{l}\text { Letras e Céd. } \\
\text { Hipotecárias } \\
\text { adquiridas } \\
\text { CCI, LCl e DII }\end{array}$ & $\begin{array}{l}\text { Fundos e } \\
\text { Outros(4) }\end{array}$ & Total & & \\
\hline dez| 1994 & 37.567 .953 & - & 7.487 .416 & - & 504.831 & 2.341 .626 & 47.901 .826 & 7.173 .941 & 55.075 .767 \\
\hline dez|1995| & 48.319 .634 & - & 11.466 .007 & - & $842.745,000$ & 2.770 .705 & 63.399 .091 & 7.346 .885 & 70.745 .976 \\
\hline dez| $1996 \mid$ & 46.125 .941 & - & 17.563 .562 & - & 1.085 .417 & 2.721 .890 & 67.496 .810 & 8.597 .233 & 76.094 .043 \\
\hline dez|1997| & 50.392 .367 & - & 20.213 .543 & - & 3.182 .872 & 4.078 .323 & 77.867 .105 & 12.014 .244 & 89.881 .349 \\
\hline dez| 1998 & 54.885 .742 & 236.298 & 26.370 .670 & - & 3.313 .866 & 1.749 .641 & 86.556 .217 & 13.294 .387 & 99.850 .604 \\
\hline dez| 1999 & 49.935 .114 & 297.699 & 33.483 .814 & - & 2.555 .527 & 3.485 .692 & 89.757 .846 & 13.144 .363 & 102.902 .209 \\
\hline dez|2000 & 36.839 .220 & 307.215 & 48.195 .469 & - & 3.004 .123 & 3.595 .408 & 91.941 .435 & 12.753 .891 & 104.695 .326 \\
\hline dez|2001 & 30.745 .688 & 333.474 & 43.996 .992 & - & 2.692 .957 & 5.679 .235 & 83.448 .346 & 14.035 .476 & 97.483 .822 \\
\hline dez|2002 & 20.718 .303 & 12.087 .957 & 28.878 .426 & 34.691 .445 & 618.081 & 5.697 .764 & 102.691 .976 & 22.414 .061 & 125.106 .037 \\
\hline dez|2003 & 24.909 .766 & 12.874 .151 & 30.996 .278 & 33.669 .531 & 794.737 & 2.144 .976 & 105.389 .439 & 22.938 .069 & 128.327 .508 \\
\hline dez|2004 & 29.330 .133 & 13.117 .915 & 33.213 .969 & 26.744 .961 & 543.396 & 2.665 .887 & 105.616 .261 & 25.144 .118 & 130.760 .379 \\
\hline dez|2005 & 36.686 .380 & 14.677 .203 & 34.642 .990 & 17.138 .740 & 476.370 & 3.994 .320 & 107.616 .003 & 26.720 .350 & 134.336 .353 \\
\hline dez|2006 & 45.262 .803 & 16.319 .004 & 37.138 .783 & 12.553 .011 & 273.458 & 9.486 .510 & 121.033 .569 & 29.239.557 & 150.273 .126 \\
\hline dez $|2007|$ & 56.802 .181 & 17.211 .202 & 38.369 .169 & 6.965 .609 & 406.970 & 16.486 .767 & 136.241 .898 & 36.871 .705 & 173.113 .603 \\
\hline dez|2008| & 76.465 .785 & 22.128 .051 & 39.408 .157 & 167.337 & 539.628 & 27.060 .124 & 165.769 .082 & 42.878 .545 & 208.647.627 \\
\hline
\end{tabular}

TABELA 6B

Direcionamento dos recursos da poupança - Fontes.

\begin{tabular}{|c|c|c|c|c|}
\hline \multirow[b]{2}{*}{ Mês |Ano } & \multicolumn{4}{|c|}{ FONTES } \\
\hline & $\begin{array}{l}\text { Recursos da } \\
\text { Poupança(5) }\end{array}$ & $\begin{array}{l}\text { Repasses, } \\
\text { Refinanc., } \\
\text { Fundose } \\
\text { Prog.Sociais }\end{array}$ & $\begin{array}{l}\text { Letras e Céd. } \\
\text { Hipot. } \\
\text { Emitidas, DII } \\
\text { Captados }\end{array}$ & Total \\
\hline dez| $1994 \mid$ & 36.883 .878 & 2.971 .695 & 3.328 .011 & 43.183 .584 \\
\hline dez|1995| & 51.362 .412 & 1.783 .253 & 4.807 .300 & 57.952 .965 \\
\hline $\operatorname{dez}|1996|$ & 57.418 .697 & 863.377 & 7.216 .317 & 65.498 .391 \\
\hline dez|1997| & 80.050 .377 & 889.104 & 10.848.912 & 91.788 .393 \\
\hline dez|1998| & 89.537 .350 & 863.967 & 9.060 .379 & 99.461 .696 \\
\hline dez|1999| & 91.437 .541 & 632.772 & 9.681 .612 & 101.751 .925 \\
\hline dez $|2000|$ & 91.443 .150 & 262.065 & 11.134 .841 & 102.840 .056 \\
\hline $\operatorname{dez}|2001|$ & 97.146 .687 & 1.463 .716 & 12.659 .511 & 111.269 .914 \\
\hline $\operatorname{dez}|2002|$ & 112.423 .442 & 4.471 .805 & 10.623.320 & 127.518 .567 \\
\hline dez|2003 & 115.258 .086 & 6.966 .901 & 13.465.959 & 135.690 .946 \\
\hline dez| $2004 \mid$ & 126.870 .740 & 9.306 .415 & 12.863 .730 & 149.040 .885 \\
\hline $\operatorname{dez}|2005|$ & 135.516 .998 & 12.094 .595 & 11.386 .979 & 158.998.572 \\
\hline dez|2006 & 150.713 .838 & 15.715 .553 & 9.858 .822 & 176.288 .213 \\
\hline dez|2007| & 188.575 .515 & 18.663 .695 & 9.258 .205 & 216.497 .415 \\
\hline $\operatorname{dez}|2008|$ & 215.400 .282 & 24.530 .026 & 10.530 .546 & 250.460 .854 \\
\hline
\end{tabular}

Fonte: BACEN - Estatísticas Básicas do SFH - SBPE. Valores em $\mathrm{R} \$ 1000$

(1) Financiamentos habitacionais para aquisição, produção, desemb. futuros, financ. compromissados, aquisição mat. cons-trução e cartas de crédito formalizadas.

(2) Financiamentos para aquisição, constr. e reforma de imóveis co-merciais e residenciais; produção de imóveis comerciais e residenciais; desemb. futuros; financ. Compromissados para imóv. comerciais e residenciais, aquisição material para cons-trução e cartas de crédito concedidas

(3) Creditos do FCVS utilizados, permutados ou alienados - saldos dos financiamentos negociados no âmbito do PROER.

(4) Inclui imóveis Hab. SFH recebidos, FABRE, FESTA, Lei 8004, ope-rações faixa especial, direitos creditórios imóveis resid., certificados de recebíveis imobiliários, títulos de Cias. Hipotecárias e/ou Securitizadoras, imóveis recebidos em liquidação de financiamentos habi-tacionais, Cartas de Garantia - CRI - Res 3155, SFH Fin Hab. Empreg. Art.2 Res 3259, SFH acréscimo multiplic Art.14 Res 3347, SFH Proj. Inv. San-incXX Art.2 Res 3347, SFH Est. Viab. San-incXXI Art.2 Res.3347, SFH Fin. Aquis. C/Mult.Art. 13 Res.3347,SFH Dif. Dez.2005 - Art.3 Res. 3347.

(5) Informações provenientes das instituições (Regime de (aixa).

ciamento habitacional integram o rol de livre destinação de recursos. Muito provavelmente os recursos de fins dos anos 90 e início dos anos 2000 foram destinados à compra de títulos públicos, com baixo risco, alta liquidez e que remuneravam o investidor com base na taxa básica de juros, que em 2000 era aproximadamente 
16\% a.a. Ou seja, a poupança, inicialmente voltada para financiamento à produção

e à aquisição de habitação, estava contribuindo com o financiamento do déficit público brasileiro e com o enriquecimento das instituições financeiras, visto que captavam o recurso na poupança (6\%) e o aplicavam com a remuneração da taxa básica de juros da economia.

A tabela anterior, que trata da exigibilidade no âmbito do direcionamento dos recursos da poupança, sugere que ainda há espaço para que os financiamentos imobiliários cresçam dentro das regras atuais, em termos de disponibilização do crédito. No entanto, o crescimento do percentual de 49,25\% de atendimento à exigibilidade em dezembro de 2002 para 78,95\% em dezembro de 2003 demonstra que há uma

TABELA 7

EXIGIBILIDADE DO DIRECIONAMENTO DOS RECURSOS - Aplicações em financiamentos habitacionais efetivos.

\begin{tabular}{|c|c|c|c|c|c|c|c|}
\hline \multirow[b]{2}{*}{ Mês|Ano } & \multirow[b]{2}{*}{$\begin{array}{l}\text { Exibilidades Fin. } \\
\text { Imobiliário' (A) }^{1}\end{array}$} & \multicolumn{3}{|c|}{ Financiamentos Imobiliários } & \multirow[b]{2}{*}{$B / D \%$} & \multirow[b]{2}{*}{$C / D \%$} & \multirow[b]{2}{*}{ D/A \% } \\
\hline & & $\mathrm{TM}^{2}(\mathrm{~B})$ & $\begin{array}{c}\text { No âmbito do } \\
\text { SFH } \\
\text { (Habitacionais) }^{3} \\
\text { (C) }\end{array}$ & $\begin{array}{l}\text { TOTAL } \\
\mathrm{D}=\mathrm{B}+\mathrm{C}\end{array}$ & & & \\
\hline \begin{tabular}{l|l|l} 
dez & 1994
\end{tabular} & 12.052 .597 & 1.763 .935 & 25.685 .400 & 27.449 .335 & 6,43 & 93,57 & 227,75 \\
\hline dez|1995 & 15.749 .912 & 2.168 .725 & 34.436 .018 & 36.604 .743 & 5,92 & 94,08 & 232,41 \\
\hline dez|1996 & 18.331 .405 & 1.900 .358 & 36.104 .956 & 38.005 .314 & 5,00 & 95,00 & 207,32 \\
\hline dez| 1997 & 21.843 .761 & 2.972 .088 & 38.381 .930 & 41.354 .018 & 7,19 & 92,81 & 189,32 \\
\hline dez| 1998 & 27.426 .416 & 2.017 .398 & 38.342 .395 & 40.359 .793 & 5,00 & 95,00 & 147,16 \\
\hline dez|1999 & 24.414 .785 & 1.175 .365 & 31.913 .236 & 33.088 .601 & 3,55 & 96,45 & 135,53 \\
\hline dez 2000 & 26.444 .102 & 1.110 .822 & 20.569 .746 & 21.680 .568 & 5,12 & 94,88 & 81,99 \\
\hline dez | 2001 & 26.514 .431 & 6.283 .937 & 8.988 .158 & 15.272 .095 & 41,15 & 58,85 & 57,60 \\
\hline dez| 2002 & 31.752 .912 & 6.153 .192 & 11.559 .278 & 17.712 .470 & 34,74 & 65,26 & 55,78 \\
\hline dez|2003 & 34.686 .862 & 6.022 .842 & 13.660 .404 & 19.683 .246 & 30,60 & 69,40 & 56,75 \\
\hline \begin{tabular}{l|l} 
& 2004
\end{tabular} & 37.460 .531 & 5.679 .875 & 15.397 .779 & 21.077 .654 & 26,95 & 73,05 & 56,27 \\
\hline dez 2005 & 41.498 .876 & 6.176 .662 & 19.241 .271 & 25.417 .933 & 24,30 & 75,70 & 61,25 \\
\hline dez $\mid 2006$ & 45.124 .930 & 5.855 .597 & 22.951 .293 & 28.806 .890 & 20,33 & 79,67 & 63,84 \\
\hline dez | 2007 & 54.134 .115 & 5.481 .172 & 26.738 .904 & 32.220 .076 & 17,01 & 82,99 & 59,52 \\
\hline dez 2008 & 65.595 .339 & 7.079 .349 & 34.902 .916 & 41.982 .265 & 16,86 & 83,14 & 64,00 \\
\hline
\end{tabular}

Fonte: BACEN - Estatísticas Básicas do SFH - SBPE.

$R \$ 1000$

$\left(^{*}\right)$ - Até dez/97 os saldos em operações de Financiamentos Habitacionais correspondem a todas as aplicações legais previstas em operações do SFH (Efetivos + Aplicações Legais).

(1) Exigibilidades: 65\% do menor dos dois: 1) Média aritmética dos saldos diários dos depósitos de poupança do mês sob referência, ou, 2) a média aritmética dos saldos diários dos depósitos de poupança nos 12 meses antecedentes ao mês sob referência.

(2) Financiamentos habit. a taxas de mercado inclui: Fin. Aquis., Constr e reforma de habitação, produção de imóveis resid., desembolsos futuros, financ. compromissados, aquisição de mat. construção e cartas de crédito formalizadas.

(3) Financ. efetivos no âmbito do SFH abrange: Financ. para aquisição, para produção, desembolsos futuros, financiam. compromiss., aquisição de mat. const., cartas de crédito formalizadas. 
tendência ascendente de aplicação dos recursos da poupança em financiamento imobiliário e que, portanto, o percentual de recursos recolhidos ao Banco Central por não atendimento à exigibilidade vem diminuindo.

\subsubsection{FGTS}

Após o período de paralisação das atividades do FGTS por conta dos problemas ocorridos com as contratações do período 1990 -1992, as contratações com o FGTS foram retomadas em 1995. No entanto, importantes mudanças foram feitas pelo Conselho Curador visando coibir o tipo de contratações ocorridas no triênio 19901992. A principal delas foi certamente o financiamento direto à demanda, ao beneficiário final, e não à produção. A justificativa da mudança reside na convicção de que, dessa forma, o fundo estaria mais seguro em relação às contratações visto que o beneficiário final já estaria caracterizado desde o início da contratação.

Assim, em 1995 foi criado o programa 'carro chefe' das contratações do FGTS na década de 90 e mesmo nos anos 2000, o Programa Carta de Crédito. O Programa Carta de Crédito se subdivide em dois, o Carta de Crédito Individual e o Carta de Crédito Associativa, que visa basicamente a concessão de crédito direto ao mutuário final - pessoa física, integrante da população alvo do FGTS por meio das seguintes modalidades:

- Aquisição de unidade habitacional ou lote urbanizado;

- Construção de unidade habitacional;

- Conclusão, ampliação, reforma e melhoria de unidade habitacional;

- Aquisição de material de construção.

Mesmo sob a forma associativa os recursos são destinados a pessoa física envolvida na operação, que devem estar agrupadas em condomínio ou por sindicatos, cooperativas, associações, COHAB e/ou órgãos assemelhados ou entidades privadas voltadas à produção habitacional, denominadas entidades organizadoras. É direcionado para dois executores distintos:

- Sindicatos, Cooperativas, Associações e Entidades privadas; e

- Companhias de Habitação - COHAB e Órgãos Assemelhados. 
FGTS: Evolução do número de operações - Programa Carta de Crédito - 1997 a 2008.

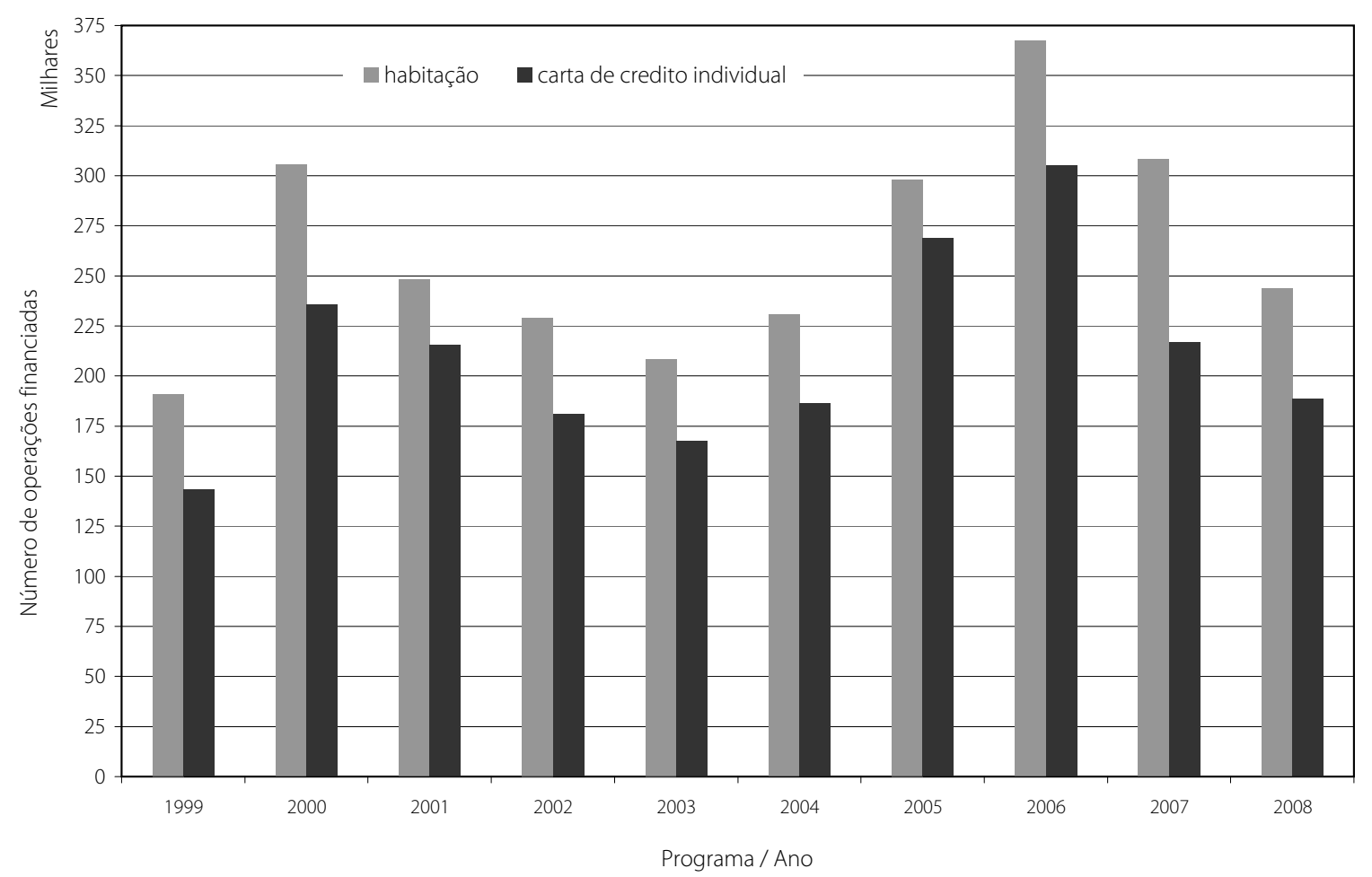

Os números do período de 1997 a 2002 demonstram o crescimento das contratações do FGTS especialmente no programa Carta de Credito Individual.

As contratações destinadas ao poder público com recursos do FGTS, no entanto, não puderam prosperar por conta do contingenciamento de crédito feito ao setor público pelo Banco Central (Conselho Monetário Nacional) em 199723. O programa destinado ao setor público, o Pro-Moradia, cujo objetivo descrito é o apoio ao poder público no desenvolvimento de ações integradas e articuladas com outras políticas setoriais, tem modalidades importantes no combate às necessidades habitacionais tais como elas se apresentam hoje no país, como urbanização de áreas, infra-estrutura em conjuntos habitacionais, entre outras. No entanto, o desempenho do programa nesse período foi realmente insatisfatório.

23 Castro (1999) identificou as resoluções do CMN e outras normas responsáveis pelo contingenciamento dos recursos públicos: a Resolução CMN No.2.461/1997 definiu regras para o contingenciamento de crédito ao setor público e estabeleceu limites para a realização de novas operações. A Resolução Senado Federal No.40/2001 definiu limites globais para o montante da dívida pública consolidada e mobiliária (Estados, DF e Municípios). A Resolução Bacen No.2.827/2001 consolida e redefine regras de contingenciamento de crédito para o setor público, limitando o montante de operações com o setor público também frente ao patrimônio da instituição financeira. 
A partir de 2003, houve mudanças importantes na condução da política feita com

os recursos do FGTS. A criação do Ministério das Cidades em 2003 mudou a constituição e a forma do Conselho Curador no que diz respeito à gestão da aplicação dos recursos do FGTS. A partir dessa data o Ministério das Cidades passou a ser o responsável pela gestão da aplicação dos recursos do Fundo, o que significa, entre outras atribuições, a de estabelecer metas a serem alcançadas nos programas de habitação popular, saneamento básico e infra-estrutura urbana.

Também a melhoria do ambiente creditício impactou os financiamentos pelo FGTS. O Conselho Curador, em conjunto com o órgão operador do FGTS, a Caixa Econômica Federal, implementaram uma série de medidas visando a resolução de aspectos legais, institucionais e técnico-operacionais, que dificultavam o processo de execução do orçamento operacional do FGTS. Assim, desde 2003, programas, processos e procedimentos foram aprimorados, incluindo melhorias na sempre temida avaliação de risco de crédito para pessoas físicas e jurídicas.

A partir de dezembro de 2003 o contingenciamento de crédito ao setor público foi excepcionado em diversas resoluções do CMN para programas específicos de aplicação de recursos do FGTS. Verifica-se então um aumento na utilização dos recursos do FGTS nas áreas de saneamento ambiental e de habitação no programa específico destinado ao setor público, o Pró-Moradia.

Em 2004 uma mudança fundamental foi feita pelo Ministério das Cidades em conjunto com o Conselho Curador do FGTS no sentido de ampliar o acesso às faixas de menor renda aos recursos do Fundo. Ao instituir um programa de aplicação de recursos e elaboração de proposta orçamentária para o período de 2005 a 2008, foi instituído também um novo modelo de concessão de subsídios. A Resolução CCFGTS no 460, de 14 de dezembro de 2004, garantiu os 60\% dos recursos de aplicação do FGTS para a área de habitação popular, de acordo com a lei 8.036/90, 30\% para saneamento básico, 5\% para infra-estrutura urbana e 5\% para operações especiais (percentual progressivamente reduzido até sua extinção a partir de 2008). Foram revistos também os pesos e ponderações regionais considerando o déficit habitacional, população urbana e déficit dos serviços de água e esgoto. 
GRÁFICO 9

Atendimento por faixa de renda - FGTS, FAR, FDS, OGU, FAT, CAIXA e SBPE.

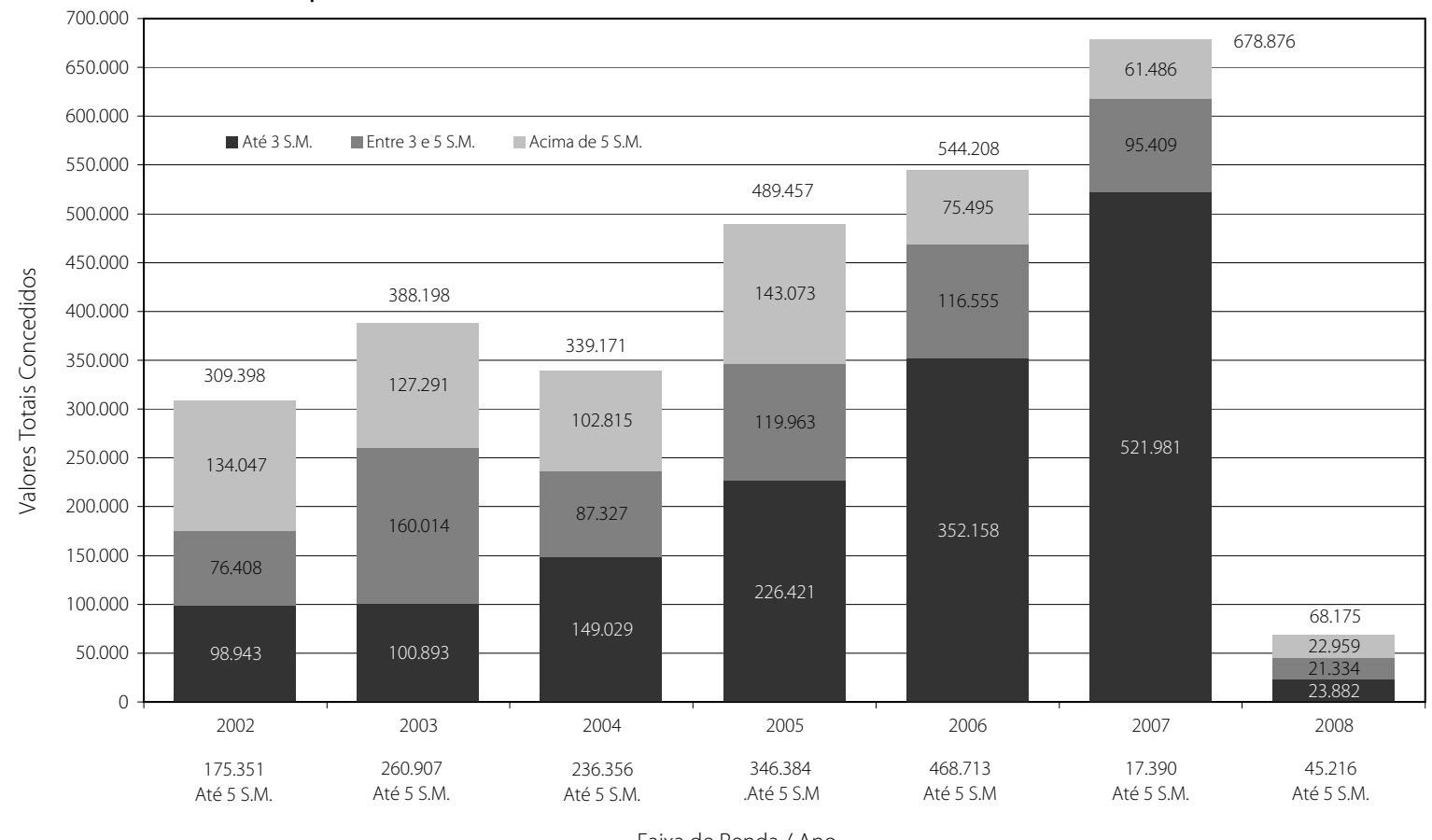

Faixa de Renda / Ano

Fontes de Recursos: FGTS, FAR, FDS, OGU, FAT, CAIXA, SBPE. Estão somadas todas as fontes de recursos Fonte de Informação: Ministério das Cidades e Relatório CEF. Informações atualizadas até 30/04/2008.

Mas o mais importante da Resolução no 460, cuja vigência iniciou em maio de 2005, foi mesmo

o novo modelo de concessão dos descontos dirigidos a financiamentos a pessoas físicas com renda familiar mensal bruta de até $R \$ 1.500,00$. Essas diretrizes e a nova forma de concessão dos descontos, com vigência prevista para o período de 01 de janeiro de 2005 a 31 de dezembro de 2008, permitiram que os recursos do Fundo alcançassem efetivamente a população de mais baixa renda, até um salário mínimo, e ampliaram as aplicações globais dos recursos, que atingiram o montante de $R \$ 4.447 .337$ mil, em 2005, na área de Habitação, excluindo-se as operações no âmbito do PAR ${ }^{24}$.

Esse desconto é na verdade um subsídio destinado diretamente à pessoa física que contrata um financiamento com recursos do FGTS e cuja renda familiar bruta atenda o limite de renda (em 2004, R\$ 1.500,00). Esse subsídio tem sua origem em recursos oriundos de parte do rendimento auferido pelos recursos do FGTS em aplicações financeiras ("diferencial entre as aplicações financeiras do Fundo (à taxas de juros 
praticadas pelo mercado) e as taxas de remuneração pagas às contas vinculadas ao

Fundo"). Dessa forma, esses recursos não têm obrigatoriedade de retorno e podem ser utilizados 'a fundo perdido', ampliando sobremaneira a capacidade de atendimento do FGTS às faixas de menor renda ${ }^{25}$.

O aumento de recursos às faixas de renda até 3 salários mínimos é notável, sendo possível identificar um aumento de mais de 5 vezes do valor concedido a essa faixa de renda no ano de 2002. No ano de 2007, por exemplo, do total dos atendimentos habitacionais realizados com os recursos do FGTS, FAR, FDS, OGU, FAT, CAIXA, SBPE, 76,8\% foram destinados à faixa de renda até 3 salários mínimos.

Ainda que não seja nosso objetivo a análise da aplicação dos recursos do FGTS no período, a questão que pode ser colocada nesse inegável aumento do acesso das famílias de menor renda a um atendimento habitacional é qual tipo de atendimento encontra-se acessível, visto que os financiamentos concedidos à pessoa física se dão sob o programa Carta de Crédito Individual que, como se sabe, incorpora modalidades distintas como aquisição de imóvel novo ou usado até aquisição de material de construção, por exemplo. Os dados agregados não permitem uma leitura fidedigna de qual é o número exato de financiamentos e repasse de recursos que são feitos nas modalidades aquisição ou construção de imóveis e qual é o número destinado simplesmente a material de construção. Ainda que essa diferenciação não seja importante para a contabilização do número de atendimentos habitacionais e inclusão das faixas de renda mais baixas no financiamento do FGTS, é importante para a mensuração da mitigação do déficit habitacional qualitativo e do impacto urbanístico dos recursos alocados.

Em 2006, a Resolução n. 518 do Conselho Curador do FGTS promoveu mudanças na distribuição do subsidio do FGTS. Segundo o Relatório de Gestão daquele ano, foi feito um "ajuste da curva relativa à concessão de desconto aos beneficiários dos financiamentos residentes em municípios integrantes das regiões metropolitanas, capitais

25 Segundo o Relatório de Gestão do FGTS do ano de 2006, "A referência para definição do orçamento anual de recursos destinados aos descontos é: até 50\% do resultado das aplicações financeiras, apurado no exercício anterior, que vier a exceder a remuneração do Fundo (TR + 6\%); o equilibrio financeiro do FGTS; e, a necessidade de formação de reservas para saldar compromissos futuros". 
TABELA 8A

FGTS: Evolução do financiamento - 1995 a 2008.

\begin{tabular}{|c|c|c|c|c|c|c|}
\hline Ano & Programa & $\begin{array}{c}\text { Valores } \\
\text { Orçamentarios } \\
\text { Finais (A) }\end{array}$ & $\begin{array}{l}\text { Orçamento } \\
\text { Realizado (B) }\end{array}$ & $B / A$ & Valores Contratados & $\begin{array}{c}\text { Numero de } \\
\text { Operações e UH } \\
\text { Financiadas }\end{array}$ \\
\hline \multirow{3}{*}{1995} & habitação & $R \$ 1.478 .893$ & 424.875 & $29 \%$ & $\mathrm{R} \$ 424.875$ & \\
\hline & saneamento infra-estrutura & $\mathrm{R} \$ 895.547$ & 80.647 & $9 \%$ & $\mathrm{R} \$ 80.647$ & \\
\hline & total & $\mathrm{R} \$ 2.374 .440$ & 505.522 & $21 \%$ & $\mathrm{R} \$ \mathbf{5 0 5 . 5 2 2}$ & \\
\hline \multirow{3}{*}{1996} & habitação & $\mathrm{R} \$ 2.512 .236$ & 2.033 .396 & $81 \%$ & $R \$ 2.033 .396$ & \\
\hline & saneamento infra-estrutura & $\mathrm{R} \$ 1.603 .938$ & 1.005 .401 & $63 \%$ & $\mathrm{R} \$ 1.005 .401$ & \\
\hline & total & R\$ 4.116.174 & 3.038 .797 & $74 \%$ & $R \$ 3.038 .797$ & \\
\hline \multirow{9}{*}{1999} & habitação & $\mathrm{R} \$ 2.742 .409$ & $\mathrm{R} \$ 2.043 .024$ & $74 \%$ & $\mathrm{R} \$ 2.043 .024$ & 190.879 \\
\hline & carta de credito individual & R\$ 1.378.240 & $\mathrm{R} \$ 1.242 .183$ & $90 \%$ & $\mathrm{R} \$ 1.242 .183$ & 143.284 \\
\hline & carta de credito associativa entidades & $\mathrm{R} \$ 913.454$ & $R \$ 763.264$ & $84 \%$ & $R \$ 763.264$ & 43.823 \\
\hline & carta de credito associativa cohab & $\mathrm{R} \$ 39.601$ & $R \$ 28.531$ & $72 \%$ & $R \$ 28.531$ & 2.725 \\
\hline & apoio a producao & $\mathrm{R} \$ 76.705$ & $\mathrm{R} \$ 9.046$ & $12 \%$ & $\mathrm{R} \$ 9.046$ & 1.047 \\
\hline & pro-moradia & $\mathrm{R} \$ 334.409$ & $\mathrm{R} \$ 0$ & $0 \%$ & $\mathrm{R} \$ 0$ & 0 \\
\hline & par & $R \$ 2.435 .000$ & $\mathrm{R} \$ 2.400 .000$ & $99 \%$ & $\mathrm{R} \$ 131.725$ & 6.958 \\
\hline & saneamento infra-estrutura & $\mathrm{R} \$ 1.257 .591$ & $\mathrm{R} \$ 2.376$ & $0 \%$ & $\mathrm{R} \$ 2.376$ & \\
\hline & total & R\$ 6.435.000 & $\mathrm{R} \$ \mathbf{4 . 4 4 5 . 4 0 0}$ & $69 \%$ & $\mathrm{R} \$ 2.177 .125$ & \\
\hline \multirow{9}{*}{2000} & habitação & $\mathrm{R} \$ 4.095 .472$ & $\mathrm{R} \$ 3.282 .081$ & $80 \%$ & $\mathrm{R} \$ 3.282 .081$ & 305.576 \\
\hline & carta de credito individual & R\$ 2.626.871 & $R \$ 2.201 .936$ & $84 \%$ & R\$ 2.201.936 & 235.628 \\
\hline & carta de credito associativa entidades & $\mathrm{R} \$ 1.327 .455$ & $\mathrm{R} \$ 997.261$ & $75 \%$ & $\mathrm{R} \$ 997.261$ & 67.781 \\
\hline & carta de credito associativa cohab & $R \$ 59.704$ & $\mathrm{R} \$ 22.735$ & $38 \%$ & $R \$ 22.735$ & 2.107 \\
\hline & apoio a producao & $\mathrm{R} \$ 10.645$ & $R \$ 506$ & $5 \%$ & $\mathrm{R} \$ 506$ & 60 \\
\hline & pro-moradia & $\mathrm{R} \$ 70.797$ & $\mathrm{R} \$ 59.643$ & $84 \%$ & $\mathrm{R} \$ 59.643$ & 0 \\
\hline & par & $\mathrm{R} \$ 0$ & $\mathrm{R} \$ 0$ & $0 \%$ & $\mathrm{R} \$ 607.654$ & 30.992 \\
\hline & saneamento infra-estrutura & $\mathrm{R} \$ 204.528$ & $\mathrm{R} \$ 16.800$ & $8 \%$ & $\mathrm{R} \$ 16.800$ & \\
\hline & total & $\mathrm{R} \$ 4.300 .000$ & R\$ 3.298.881 & $77 \%$ & $R \$ 3.906 .535$ & \\
\hline \multirow{9}{*}{2001} & habitação & $\mathrm{R} \$ 3.215 .587$ & $\mathrm{R} \$ 2.650 .603$ & $82 \%$ & $\mathrm{R} \$ 2.650 .603$ & 247.990 \\
\hline & carta de credito individual & R\$ 2.069.784 & R\$ 1.877.167 & $91 \%$ & $\mathrm{R} \$ 1.877 .167$ & 215.626 \\
\hline & carta de credito associativa entidades & $\mathrm{R} \$ 1.046 .369$ & $\mathrm{R} \$ 762.500$ & $73 \%$ & $\mathrm{R} \$ 762.500$ & \multirow{2}{*}{32.364} \\
\hline & carta de credito associativa cohab & $R \$ 65.000$ & $\mathrm{R} \$ 10.936$ & $17 \%$ & R\$ 10.936 & \\
\hline & apoio a producao & $\mathrm{R} \$ 0$ & $\mathrm{R} \$ 0$ & $0 \%$ & $\mathrm{R} \$ 0$ & 0 \\
\hline & pro-moradia & $\mathrm{R} \$ 34.434$ & R\$ 0 & $0 \%$ & $\mathrm{R} \$ 0$ & 0 \\
\hline & par & $\mathrm{R} \$ 0$ & $\mathrm{R} \$ 0$ & $0 \%$ & $\mathrm{R} \$ 418.998$ & 20.253 \\
\hline & saneamento infra-estrutura & $\mathrm{R} \$ 584.413$ & $\mathrm{R} \$ 35$ & $0,01 \%$ & $\mathrm{R} \$ 35$ & \\
\hline & total & $\mathbf{R} \mathbf{3 . 8 0 0 . 0 0 0}$ & $\mathrm{R} \$ 2.650 .638$ & $70 \%$ & $\mathrm{R} \$ 3.069 .636$ & \\
\hline
\end{tabular}

Fonte: relatórios de gestão do FGTS publicados no Diário Oficial da União nos anos respectivos.

estaduais e municípios com população urbana igual ou superior a 100 mil habitantes e a ampliação do valor do desconto para as modalidades de produção e aquisição de imóveis novos". Além disso, sob a justificativa da criação de novos empregos na construção civil, a resolução também determinou que os subsídios tivessem "a aplicação de, no mínimo, 50\% dos recursos para a produção ou aquisição de imóveis novos".

No exercício de 2006 foram concedidos descontos no montante de R\$1.825.805 mil, 103,29\% superior ao registrado em 2005, quando alcançou R\$ 898.117 mil. Ainda segundo o Relatório de Gestão, "foram aproximadamente 82 mil famílias com renda de até 1 salário mínimo que obtiveram financiamentos médios de $R \$ 1.764,54$ e conquistaram descontos médios de $R \$ 8.284,15^{\prime \prime}$. Esses descontos abrangeram 84,46\% do total dos financiamentos habitacionais concedidos (361 mil), considerando as modalidades dos Programas Carta de Crédito Associativo e Individual. Do total dos descontos, 60,67\% foram no âmbito do Programa Carta de Crédito Individual. 
TABELA 8B

FGTS: Evolução do financiamento - 1995 a 2008.

\begin{tabular}{|c|c|c|c|c|c|c|}
\hline Ano & Programa & $\begin{array}{l}\text { Valores } \\
\text { Orçamentarios Finais } \\
\text { (A) }\end{array}$ & $\begin{array}{l}\text { Orçamento } \\
\text { Realizado (B) }\end{array}$ & $B / A$ & Valores Contratados & $\begin{array}{c}\text { Numero de } \\
\text { Operaçōes e UH } \\
\text { Financiadas }\end{array}$ \\
\hline \multirow{10}{*}{2002} & habitação & $\mathrm{R} \$ 3.074 .520$ & $R \$ 2.914 .992$ & $95 \%$ & $R \$ 2.914 .992$ & 229.061 \\
\hline & carta de credito individual & $R \$ 2.335 .683$ & $\mathrm{R} \$ 2.222 .317$ & $95 \%$ & $\mathrm{R} \$ 2.222 .317$ & 180.890 \\
\hline & carta de credito associativa entidades & $\mathrm{R} \$ 554.140$ & $\mathrm{R} \$ 530.931$ & $96 \%$ & $\mathrm{R} \$ 530.931$ & 29.568 \\
\hline & carta de credito associativa cohab & R\$ 56.799 & $\mathrm{R} \$ 34.435$ & $61 \%$ & $\mathrm{R} \$ 34.435$ & 12.288 \\
\hline & operações especiais & $\mathrm{R} \$ 77.001$ & $\mathrm{R} \$ 76.412$ & $99 \%$ & $\mathrm{R} \$ 76.412$ & 1.383 \\
\hline & pro-moradia & $\mathrm{R} \$ 50.897$ & $R \$ 50.897$ & $100 \%$ & $R \$ 50.897$ & 4.932 \\
\hline & par & $\mathrm{R} \$ 0$ & $\mathrm{R} \$ 0$ & $0 \%$ & $\mathrm{R} \$ 0$ & 0 \\
\hline & saneamento infra-estrutura & $\mathrm{R} \$ 752.779$ & $\mathrm{R} \$ 254.265$ & $34 \%$ & $\mathrm{R} \$ 254.265$ & \\
\hline & aquisição de cri & $\mathrm{R} \$ 100.000$ & $\mathrm{R} \$ 57.900$ & $58 \%$ & $\mathrm{R} \$ 57.900$ & \\
\hline & total & $\mathrm{R} \$ 3.927 .299$ & $\mathrm{R} \$ 3.227 .157$ & $82 \%$ & $\mathrm{R} \$ 3.227 .157$ & \\
\hline \multirow{11}{*}{2003} & habitação & $\mathrm{R} \$ 3.250 .000$ & $\mathrm{R} \$ 2.672 .391$ & $82 \%$ & $\mathrm{R} \$ 2.462 .952$ & 208.396 \\
\hline & carta de credito individual & $R \$ 2.131 .302$ & $\mathrm{R} \$ 2.047 .513$ & $96 \%$ & $\mathrm{R} \$ 2.047 .513$ & 167.641 \\
\hline & carta de crédito associativa entidades & $\mathrm{R} \$ 386.675$ & $R \$ 283.852$ & $73 \%$ & $R \$ 283.852$ & 12.868 \\
\hline & carta de crédito associativa cohab & $\mathrm{R} \$ 84.473$ & $\mathrm{R} \$ 37.604$ & $45 \%$ & $R \$ 37.604$ & 15.034 \\
\hline & operações especiais ccindividual & $R \$ 242.467$ & $R \$ 209.439$ & $86 \%$ & $\mathrm{R} \$ 0$ & 4.915 \\
\hline & operações especiais ccassociativa & $\mathrm{R} \$ 107.533$ & $\mathrm{R} \$ 93.983$ & $87 \%$ & $\mathrm{R} \$ 93.983$ & 7.938 \\
\hline & pro-moradia & $\mathrm{R} \$ 97.550$ & $\mathrm{R} \$ 0$ & $0 \%$ & $\mathrm{R} \$ 0$ & 0 \\
\hline & par & $\mathrm{R} \$ 200.000$ & $\mathrm{R} \$ 0$ & $0 \%$ & $\mathrm{R} \$ 0$ & 0 \\
\hline & saneamento infra-estrutura & $\mathrm{R} \$ 1.350 .000$ & $\mathrm{R} \$ 1.233 .694$ & $91 \%$ & $\mathrm{R} \$ 1.233 .694$ & \\
\hline & aquisição de cri & $\mathrm{R} \$ 10.000$ & $\mathrm{R} \$ 0$ & $0 \%$ & $\mathrm{R} \$ 0$ & \\
\hline & total & $\mathrm{R} \$ 4.610 .000$ & $R \$ 3.906 .085$ & $85 \%$ & $R \$ 3.696 .646$ & \\
\hline \multirow{12}{*}{2004} & habitação & $R \$ 5.034 .000$ & $\mathrm{R} \$ 3.584 .913$ & $71 \%$ & $\mathrm{R} \$ 3.584 .913$ & 230.825 \\
\hline & carta de credito individual & $R \$ 2.335 .544$ & $\mathrm{R} \$ 2.114 .787$ & $91 \%$ & $\mathrm{R} \$ 2.114 .787$ & 186.081 \\
\hline & carta de crédito associativa entidades & $R \$ 955.565$ & $\mathrm{R} \$ 319.112$ & $33 \%$ & $\mathrm{R} \$ 319.112$ & 8.766 \\
\hline & carta de crédito associativa cohab & $\mathrm{R} \$ 63.000$ & $\mathrm{R} \$ 56.701$ & $90 \%$ & $\mathrm{R} \$ 56.701$ & 19.654 \\
\hline & operações especiais ccindividual & $\mathrm{R} \$ 185.200$ & $\mathrm{R} \$ 151.487$ & $82 \%$ & $\mathrm{R} \$ 151.487$ & 3.231 \\
\hline & operações especiais ccassociativa & $\mathrm{R} \$ 134.800$ & $\mathrm{R} \$ 80.781$ & $60 \%$ & $\mathrm{R} \$ 80.781$ & 1.662 \\
\hline & apoio à produção & $\mathrm{R} \$ 110.000$ & $\mathrm{R} \$ 0$ & $0 \%$ & $\mathrm{R} \$ 0$ & 0 \\
\hline & pro-moradia & $\mathrm{R} \$ 249.891$ & $\mathrm{R} \$ 176.980$ & $71 \%$ & $\mathrm{R} \$ 176.980$ & 11.431 \\
\hline & par & $\mathrm{R} \$ 1.000 .000$ & $\mathrm{R} \$ 685.065$ & $69 \%$ & $\mathrm{R} \$ 685.065$ & 26.561 \\
\hline & saneamento infra-estrutura & $\mathrm{R} \$ 2.280 .988$ & $\mathrm{R} \$ 1.941 .075$ & $85 \%$ & $\mathrm{R} \$ 1.941 .075$ & \\
\hline & aquisição de cri & $\mathrm{R} \$ 6.800$ & $\mathrm{R} \$ 0$ & $0 \%$ & $\mathrm{R} \$ 0$ & \\
\hline & total & $R \$ 7.321 .788$ & $R \$ 5.525 .988$ & $75 \%$ & $R \$ 5.525 .988$ & \\
\hline \multirow{12}{*}{2005} & habitação & $\mathrm{R} \$ 6.521 .450$ & $\mathrm{R} \$ 5.185 .611$ & $80 \%$ & $\mathrm{R} \$ 5.185 .611$ & 298.075 \\
\hline & carta de credito individual & $R \$ 3.961 .260$ & $R \$ 3.762 .760$ & $95 \%$ & $R \$ 3.762 .760$ & 268.662 \\
\hline & carta de crédito associativa entidades & $\mathrm{R} \$ 760.691$ & $\mathrm{R} \$ 364.122$ & $48 \%$ & $\mathrm{R} \$ 364.122$ & 13.624 \\
\hline & carta de crédito associativa cohab & $\mathrm{R} \$ 132.895$ & $\mathrm{R} \$ 59.415$ & $45 \%$ & $\mathrm{R} \$ 59.415$ & 10.104 \\
\hline & operações especiais ccindividual & $\mathrm{R} \$ 215.200$ & $\mathrm{R} \$ 175.948$ & $82 \%$ & $\mathrm{R} \$ 175.948$ & \multirow{2}{*}{5.184} \\
\hline & operações especiais ccassociativa & $\mathrm{R} \$ 134.800$ & $\mathrm{R} \$ 88.917$ & $66 \%$ & $\mathrm{R} \$ 88.917$ & \\
\hline & apoio à produção & $\mathrm{R} \$ 70.000$ & $\mathrm{R} \$ 18.000$ & $26 \%$ & $\mathrm{R} \$ 18.000$ & 501 \\
\hline & pro-moradia & $\mathrm{R} \$ 246.604$ & $\mathrm{R} \$ 0$ & $0 \%$ & $\mathrm{R} \$ 0$ & 0 \\
\hline & par & $\mathrm{R} \$ 1.000 .000$ & $\mathrm{R} \$ 716.449$ & $72 \%$ & $\mathrm{R} \$ 716.449$ & 22.704 \\
\hline & saneamento infra-estrutura & R\$ 1.675 .799 & $\mathrm{R} \$ 0$ & $0 \%$ & $\mathrm{R} \$ 0$ & \\
\hline & aquisição de cri & $\mathrm{R} \$ 100.000$ & $\mathrm{R} \$ 8.175$ & $8 \%$ & $\mathrm{R} \$ 0$ & \\
\hline & total & $\mathrm{R} \$ \mathbf{8 . 2 9 7 . 2 4 9}$ & $R \$ 5.193 .786$ & $63 \%$ & $\mathrm{R} \$ 5.185 .611$ & \\
\hline \multirow{11}{*}{2006} & habitação & $\mathrm{R} \$ 7.396 .944$ & $R \$ 6.476 .830$ & $88 \%$ & $\mathrm{R} \$ 6.476 .830$ & 367.392 \\
\hline & carta de credito individual & $R \$ 5.180 .343$ & $R \$ 4.699 .392$ & $91 \%$ & $R \$ 4.699 .392$ & 304.967 \\
\hline & carta de crédito associativa entidades & $R \$ 831.104$ & $R \$ 511.222$ & $62 \%$ & $R \$ 511.222$ & 26.258 \\
\hline & carta de crédito associativa cohab & $\mathrm{R} \$ 167.176$ & $\mathrm{R} \$ 96.564$ & $58 \%$ & $\mathrm{R} \$ 96.564$ & 29.326 \\
\hline & operações especiais ccindividual & $\mathrm{R} \$ 90.000$ & $\mathrm{R} \$ 88.405$ & $98 \%$ & $\mathrm{R} \$ 88.405$ & 1.603 \\
\hline & operações especiais ccassociativa & $\mathrm{R} \$ 90.000$ & $\mathrm{R} \$ 72.834$ & $81 \%$ & $\mathrm{R} \$ 72.834$ & 4.665 \\
\hline & apoio à produção & $\mathrm{R} \$ 29.171$ & $\mathrm{R} \$ 21.842$ & $75 \%$ & $\mathrm{R} \$ 21.842$ & 535 \\
\hline & pro-moradia & $\mathrm{R} \$ 9.150$ & $\mathrm{R} \$ 9.149$ & $100 \%$ & $\mathrm{R} \$ 9.149$ & 38 \\
\hline & par & $\mathrm{R} \$ 1.000 .000$ & $\mathrm{R} \$ 977.422$ & $98 \%$ & $\mathrm{R} \$ 977.422$ & 31.113 \\
\hline & saneamento infra-estrutura & $\mathrm{R} \$ 2.314 .746$ & $\mathrm{R} \$ 538.785$ & $23 \%$ & $\mathrm{R} \$ 538.785$ & \\
\hline & total & $\mathrm{R} \$ 9.711 .690$ & $\mathrm{R} \$ 7.015 .615$ & $72 \%$ & $\mathrm{R} \$ \mathbf{7 . 0 1 5 . 6 1 5}$ & \\
\hline \multirow{9}{*}{2007} & habitação & $\mathrm{R} \$ 10.650 .000$ & $\mathrm{R} \$ 9.267 .222$ & $87 \%$ & $\mathrm{R} \$ 9.267 .222$ & 308.072 \\
\hline & carta de credito individual & $\mathrm{R} \$ 4.778 .681$ & $R \$ 4.567 .371$ & $96 \%$ & $R \$ 4.567 .371$ & 216.624 \\
\hline & carta de crédito associativo & $\mathrm{R} \$ 1.011 .945$ & $R \$ 923.323$ & $91 \%$ & R\$ 923.323 & 69.839 \\
\hline & apoio à produção & $\mathrm{R} \$ 309.374$ & $\mathrm{R} \$ 268.234$ & $87 \%$ & $\mathrm{R} \$ 268.234$ & 7.615 \\
\hline & pro-moradia & $\mathrm{R} \$ 650.000$ & $\mathrm{R} \$ 510.916$ & $79 \%$ & $\mathrm{R} \$ 510.916$ & 13.994 \\
\hline & par & $\mathrm{R} \$ 650.000$ & $\mathrm{R} \$ 630.397$ & $97 \%$ & $\mathrm{R} \$ 630.397$ & 20.128 \\
\hline & saneamento infra-estrutura & $\mathrm{R} \$ 3.150 .000$ & $\mathrm{R} \$ 2.366 .981$ & $75 \%$ & $\mathrm{R} \$ 2.366 .981$ & \\
\hline & aquisição de cri & $\mathrm{R} \$ 100.000$ & $\mathrm{R} \$ 0$ & $0 \%$ & $\mathrm{R} \$ 0$ & \\
\hline & total & R\$ 13.800.000 & $\mathrm{R} \$ 11.634 .203$ & $84 \%$ & R\$ 11.634.203 & \\
\hline \multirow{8}{*}{2008} & habitação & $\mathrm{R} \$ 13.450 .000$ & R\$ 9.684.195 & $72 \%$ & $\mathrm{R} \$ 9.684 .195$ & 243.706 \\
\hline & carta de credito individual & $R \$ 6.666 .253$ & $R \$ 6.582 .183$ & $99 \%$ & $R \$ 6.582 .183$ & 188.750 \\
\hline & carta de crédito associativo & $\mathrm{R} \$ 1.189 .260$ & $R \$ 1.105 .960$ & $93 \%$ & $R \$ 1.105 .960$ & 29.714 \\
\hline & apoio à produção & $\mathrm{R} \$ 544.487$ & $\mathrm{R} \$ 504.221$ & $93 \%$ & $\mathrm{R} \$ 504.221$ & 11.366 \\
\hline & pro-moradia & $\mathrm{R} \$ 2.050 .000$ & $\mathrm{R} \$ 1.053 .956$ & $51 \%$ & $\mathrm{R} \$ 1.053 .956$ & 13.876 \\
\hline & par & $R \$ 3.000 .000$ & $\mathrm{R} \$ 437.875$ & $15 \%$ & $\mathrm{R} \$ 437.875$ & 13.051 \\
\hline & saneamento infra-estrutura & R\$ 6.950 .000 & $\mathrm{R} \$ 3.162 .908$ & $46 \%$ & $\mathrm{R} \$ 3.162 .908$ & \\
\hline & total & R\$2 20.400.000 & R\$ 12.847.103 & $63 \%$ & R\$ 12.847.103 & \\
\hline
\end{tabular}

Fonte: Relatórios de Gestão do FGTS publicados no Diário Oficial da União nos anos respectivos 
A robustez financeira do FGTS, como é chamado o equilíbrio econômico-financeiro do FGTS, tem permitido a utilização dos recursos auferidos com rendimentos na ampliação do acesso a famílias de baixa renda. No entanto, segundo documento do PLANHAB, Plano Nacional de Habitação desenvolvido no âmbito da Secretaria Nacional de Habitação do Ministério das Cidades, esse montante destinado ao subsídio poderia ser ainda maior: "O total aplicado entre 2005 e 2007 foi de $R \$ 4,034$ bilhões. Com base nos resultados líquidos auferidos nesse período e com base na alíquota máxima de $50 \%$, poderiam ter sido concedidos aproximadamente $R \$ 6,5$ bilhões em descontos ${ }^{126}$.

De fato, os valores aplicados pelo FGTS ao longo dos últimos anos apresentam uma curva crescente, contribuindo para o boom imobiliário de 2007 e 2008.

Verifica-se que o orçamento final do ano de 2008 é aproximadamente 8,5 vezes o orçamento de 1995, o que demonstra a capacidade financeira do Fundo e também a disposição política e possibilidade da inversão desses recursos nas áreas de habitação e saneamento e infra-estrutura.

No entanto, a execução do orçamento ainda é muito diferenciada entre os diversos programas de aplicação do FGTS. No ano de 2008, quase a totalidade de recursos do programa Carta de Crédito Individual, que agrega diversas modalidades como foi descrito anteriormente, foi executado, enquanto que o programa Pró-Moradia conseguiu executar apenas metade do orçamento disponibilizado ao agente operador.

A execução dos programas de aplicação em saneamento e mesmo o Pró-Moradia, voltado ao poder público ou que tenham a participação ativa do poder público, tendem mesmo a ter uma execução mais lenta se comparada com a execução dos programas ditos de 'balcão', já que esses dependem unicamente da negociação contratual entre o agente financeiro e o mutuário/consumidor, ao contrário dos programas com o poder público, que dependem de articulações políticas para a

26 Ainda segundo o Planhab, "Já para o próximo quadriênio, o orçamento do CCFGTS estabeleceu a concessão de $R \$ 1.200$ milhões em 2008; $R \$ 1.188$ milhões em 2009; $R \$ 1.148$ milhões em 2010 e $R \$ 1.153$ milhões em 2011, totalizando $R \$ 4.688$ milhões nos 4 anos. Observa-se, portanto, uma tendência de queda na concessão desses subsídios. Como o volume disponível para aplicação em subsídios é função dos resultados das receitas financeiras, a tendência de queda é de fato esperada, em função do declínio das taxas Selic, porém no médio prazo e em ritmo bem mais suave que o já apresentado". 
aprovação de leis, destinação de terrenos públicos, aprovações urbanísticas entre outras documentações. No caso do financiamento 'de balcão', o controle feito sobre a localização da unidade a ser adquirida e/ou reformada é feita analisando-se a documentação expedida pelos órgãos de fiscalização do uso e ocupação do solo das prefeituras municipais, quando é o caso.

Por conta do custo de captação do recurso (TR+3\%, que é o valor pago aos detentores das contas vinculadas) e das normas exaradas pelo Conselho Curador, os financiamentos com base nos recursos do FGTS tendem a atingir faixas de mais baixa renda do que os financiamentos do SBPE. Daí a importância dos recursos do FGTS para a execução de uma política habitacional comprometida com a solução do déficit habitacional.

Percebemos ao longo deste capítulo a importância do Estado na montagem e articulação de um sistema nacional de crédito destinado à habitação. Os números, a evolução institucional, a arquitetura financeira, todos os aspectos demonstram o papel fundamental que o Estado tem na estruturação da política de crédito visando conformar uma política pública. Dessa forma, a defesa de um estado 'mínimo' no fomento à produção habitacional para renda média e baixa parece não se sustentar quando olhamos para o desenvolvimento do SFH no Brasil. Analisemos agora a proposta do SFI. 
CAPÍTULO 3 SFI: o Sistema Financeiro Imobiliário 
A extinção do BNH em 1986, como se sabe, não extingüiu o Sistema Financeiro de Habitação, que continua operando com os recursos inicialmente a ele destinados por meio do SBPE e FGTS. Os passivos e ativos do Sistema foram transferidos para a Caixa Econômica Federal após a extinção do BNH, que vem, desde então, participando da operacionalização do SFH como agente financeiro, no caso do SBPE e como agente financeiro e agente o-perador, no caso do FGTS'.

A desarticulação institucional pela qual passou o setor desde a extinção do BNH já foi objeto de estudo de pesquisadores que trataram o tema de forma a demonstrar que a questão habitacional percorreu uma verdadeira 'via-crúcis institucional' desde 1986 (Arretche, 1998). Inúmeros ministérios e secretárias foram criados e extintos objetivando o equacionamento da questão habitacional, linhas de financiamento e programas e foram criados e extintos também com o mesmo fim. O que nos interessa aqui, no entanto, não é repassar essas questões, mas sim procurar analisar o contexto e o debate travado entre sindicatos patronais vinculados à construção civil, entidades de crédito imobiliário e poupança, universidades e entidades governamentais visando a construção de um novo marco regulatório para o setor do crédito imobiliário (e não apenas crédito habitacional, note-se) após a extinção do BNH, assim como a relação entre esse novo marco e o 'antigo'SFH.

Esse novo marco regulatório foi a Lei no. 9.514 que instituiu o SFI em 1997 e que tem por finalidade, segundo seu art. 10, promover o financiamento imobiliário em geral, segundo condições compatíveis com as da formação dos fundos respectivos. Ou seja, o próprio artigo da lei afirma que o fundo financeiro do qual será oriundo o financiamento é um aspecto fundamental do novo sistema de financiamento imobiliário. O SFI não estabelece limites de financiamento, taxas, valor de imóvel ou qualquer tipo de 'trava' nas operações dentro do sistema. Apenas estabelece algumas condições, visto que, segundo a lei, as operações devem ser "livremente pactuadas pelas partes". Essas condições, segundo o art. $5^{\circ}$ da referida lei, são relativas ao equilíbrio econômico financeiro contratual:

"I - reposição integral do valor emprestado e respectivo reajuste;

1 As figuras do agente financeiro e operador do FGTS estão descritas na Lei no. 8.036, de 11 de maio de 1990. 
II - remuneração do capital emprestado às taxas convencionadas no contrato;

III - capitalização dos juros;

IV-contratação, pelos tomadores de financiamento, de seguros contra os riscos de morte e invalidez permanente."

O SFI procura construir, dessa forma, um sistema financeiro que dê segurança aos agentes envolvidos no processo do crédito imobiliário, especialmente aos investidores, ponto central da lógica do funcionamento do sistema, procurando fomentar um mercado de crédito imobiliário baseado, a princípio, na lei da oferta e da procura.

Para compreender melhor o contexto, os interesses e a importância do SFI vamos estudar as características do setor imobiliário, a necessidade do crédito ao setor imobiliário, o instituto da alienação fiduciária e as características básicas da securitização imobiliária. Duas leis promulgadas em 2004 e 2005 e diversas resoluções do Conselho Monetário Nacional e instruções normativas da Secretaria da Receita Federal, que contribuíram para o fortalecimento do SFI, também serão estudadas.

\subsection{O SFI e as características do setor imobiliário}

O sistema financeiro imobiliário busca, basicamente, construir um sistema para o desenvolvimento de empreendimentos imobiliários. Dessa maneira, é difícil compreender o SFI sem compreender, ainda que de forma sucinta, o que são empreendimentos imobiliários.

Como é sabido, o crédito é de fato um componente essencial no desenho de qualquer política habitacional. Assim também se dá com setor imobiliário, que necessita imobilizar capital por um prazo relativamente longo e, por isso, demanda financiamento específico. Por isso o debate sobre o crédito imobiliário especificamente sob o ponto de vista do empreendedor se dá sobre essas bases, de que é preciso encontrar soluções que dêem velocidade e ritmo à produção de empreendimentos imobiliários e empreendimentos de base imobiliária. É importante ressal- 
tar a diferença existente entre os empreendimentos: quando se produz para vender, esse empreendimento é conhecido no mercado como empreendimento imobiliário, e quando se produz para explorar o uso, é conhecido como empreendimento de base imobiliária (Lima Jr., 1994).

Em estudo sobre o mercado de edifícios de escritórios para locação em São Paulo, Lima Jr. e Alencar afirmam que "não há no mercado oferta de financiamentos de longo prazo a taxas sustentáveis pela capacidade de geração de renda dos EBI [...] [e] como resultado a demanda deve ser respondida com empreendimentos produzidos utilizando exclusivamente recursos de investimento de capital próprio de investidores". (Lima Jr; Alencar, 2004, p. 03). Além disso, a

adequação de fluxos financeiros exigiria uma vantagem na qual investimentos de longo prazo sustentassem o processo até que ele entrasse em giro e se pudesse admitir um regime de crescimento continuado da captação, capaz de suportar o sistema até seu ponto de equilibrio, em termos de capacidade de resgatar as aplicações. Pensar assim no Brasil é, praticamente, tratar de recursos públicos. (Lima Jr., 1990, p.02) [sem grifo no original].

Ou seja, para empreendimentos imobiliários que se destinam ou para exploração de seu uso, como escritórios para locação, ou mesmo para venda imediata, os recursos viriam dos próprios investidores interessados naqueles empreendimentos.

Uma das soluções para essa citada falta de recursos é encontrada na autopromoção ou autofinanciamento.

A eficiência [é] objetivada quando os empreendedores vendem os imóveis em construção. O objetivo dos empreendedores é usar recursos dos poupadores mais cedo para diminuir o impacto dos seus investimentos na implantação e o dos poupadores é pagar melhores preços [...] isso indica que o mercado encontrou meios de superar a falta de financiamentos apropriados para implantação dos edifícios de escritório para locação, fazendo dos empreendimentos não um meio de investimento, mas um produto de poupança (Lima Jr.; Alencar, 2004, p.05).

Por conta dessas características estruturais, o crédito é um requisito básico para o desenvolvimento do setor imobiliário, tanto de empreendimentos imobiliários quanto dos de base imobiliária. Ou seja, visando o retorno de seus investimentos com o 
lucro estimado, empreendedores imobiliários não podem prescindir de um sistema de crédito que fomente essa indústria.

E é nesse contexto que se insere o Sistema Financeiro Imobiliário e não na solução ou no equacionamento do déficit habitacional brasileiro, ainda que esse argumento seja utilizado à exaustão em muitos dos documentos sobre o SFI, sejam eles oriundos da cadeia produtiva (SINDUSCON/CBIC) ou mesmo de associações de empresas que trabalham com crédito imobiliário (ABECIP)².

Em apresentação realizada no Seminário Internacional de Crédito Imobiliário promovida pelo Banco Central do Brasil em 2007, a Accenture, empresa de consultoria, apresentou dados de 2005 nos quais afirmava que o volume de crédito imobiliário representava globalmente cerca de $70 \%$ do volume de crédito concedido a pessoa física, ou seja, 12 trilhões de dólares do mercado de crédito destinado à pessoa física em 2005 (Standard \& Poors 2006 GE Consumer Finance, análise Accenture). O percentual crédito imobiliário/PIB ainda é baixo no Brasil, como também é baixo o percentual de crédito em geral em relação ao PIB, se comparado a países desenvolvidos e mesmo a outros países emergentes. A questão do baixo nível de crédito em relação ao PIB no Brasil parece ser, ao que tudo indica, uma questão macroeconômica, e não específica de setores da economia.

Esse debate, iniciado nos anos $90^{3}$, trouxe a expectativa por parte destes agentes de que poderiam ocorrer mudanças na parte regulatória do setor imobiliário, visando restabe-lecer a confiança por parte de investidores e promotores no sistema de crédito imobiliário brasileiro. Após rápida tramitação na Câmara, em 1997 foi editada a Lei 9.514, um importante marco legal do setor imobiliário, pois criou formalmente o Sistema de Financiamento Imobiliário, o SFI.

Nota-se em alguns textos acadêmicos e de sindicatos ligados aos setores imobiliários a relação praticamente direta entre o 'fracasso' do SFH e a criação do SFI, como se o estabelecimento de um novo sistema financeiro fosse a solução, ou ainda a

2 Ver Revista do SFI, publicada pela ABECIP, n. 19, ano 9, n. 17, ano 8, n. 24 ano 11, n. 18 ano 8 bem como relatórios, balanços anuais e comunicados da Comissão de Economia e Estatística da CBIC dos anos de 1994, 1995, 1996 e 1997.

3 Neste sentido, ver Lima Jr, 1990 
saída para a reformulação do financiamento habitacional no país. Para isso seria

necessária a busca de "mecanismos para contornar a crise, reformando o modelo de financiamento habitacional no Brasil. A principal medida nesse sentido foi a criação do Sistema de Financiamento Imobiliário" (FGV Projetos, 2007, p. 9).

É inegável a análise de que o SFH, mesmo nos anos em que o número de financiamentos bateu recorde, não logrou atender suficientemente a população de baixa renda, como podemos ver no capítulo anterior e como diversos autores também já citados no capítulo 2 analisaram criticamente. No entanto, a ligação direta feita entre o atendimento às camadas de renda mais baixa e a estrutura financeira de um sistema de financiamento baseado na captação livre de recursos no mercado de capitais tende a ocultar as principais caracte-rísticas do SFI e levar a conclusões precipitadas sobre sua função no fomento ao crédito imobiliário.

As críticas feitas por esses autores ${ }^{4}$ ao SFH é de que o SFH tem falhas "que contribuíram para o baixo ritmo de desenvolvimento habitacional." Essas falhas dizem respeito especialmente à sua arquitetura financeira, tais como "(i) a taxa de juros fixa; (ii) a falta de canais de comunicação entre o SFH e os demais segmentos do mercado de capitais; (iii) a instabilidade congênita do sistema, ocasionada pelo prazo de permanência incerto dos depósitos nos fundos de financiamento do crédito habitacional e (iv) seu caráter pró-cíclico (FGV Projetos, 2007, p. 7)". No entanto, as características principais do SFH permanecem mesmo após o período mais dramático do sistema que teve na extinção do BNH seu ponto culminante e, como vimos também no capítulo anterior, os números recentes do SFH chegaram a níveis em muito semelhantes aos dos 'gloriosos' anos de 79 a 82.

Voltaremos ao estudo do papel do SFI no equacionamento do déficit habitacional. Por ora, interessa saber que o SFI foi considerado um avanço em relação ao SFH pelas características de livre mercado que continha sua formulação, como se verá a seguir.

4 A este respeito, ver CARNEIRO, Dionísio D.; GOLDFAJN, Ilan. A Securitização de Hipotecas no Brasil. Texto para discussão n־426. Rio de Janeiro: Departamento de Economia da PUC, junho de 2000; FUNDAÇÃO GETÚLIO VARGAS. O Crédito Imobiliário no Brasil - Caracterização e Desafios. São Paulo: FGV-Projetos, 2007; CARNEIRO, Dionísio D.; VALPASSOS, Marcus Vinicius F. Financiamento à Habitação e Instabilidade Econômica - Experiências Passadas, Desafios e Propostas para a Ação Futura. Rio de Janeiro: FGV, 2003. 
O modelo contido no SFI não tem dependência de funding direto ou de direcionamento obrigatório, como o SFH, e procura captar fundos junto ao mercado de capitais. O SFI prevê, em seu modelo teórico, que o coração do sistema seja a captação de recursos em um mercado secundário de títulos de créditos e recebíveis imobiliários. Para isso conta com instrumentos financeiros destinados a fazer essa ponte entre o mercado de capitais e o mercado imobiliário.

Alguns instrumentos financeiros foram desenhados especialmente para esse tipo de operação, como os Certificados de Recebíveis Imobiliários - CRI (criado na Lei do SFI, lei no. 9.514/1997), as Cédulas de Crédito Imobiliário - CCl e as Letras de Crédito Imobiliário - $\mathrm{LCl}^{5}$. Outros já existiam, mas sofreram algum tipo de reformulação com a criação do SFI, tais como as Debêntures, as Letras Hipotecárias e as Cédulas de Crédito Bancário. Segue abaixo um breve resumo das principais características de cada instrumento. Importante ressaltar, no entanto que essas diferenças são relativas ao tipo de crédito, garantia, agente emissor, entre outros, não se diferenciando enquanto instrumentos de captação e intermediação de recursos no âmbito do mercado financeiro de títulos ${ }^{6}$.

Certificado de Recebíveis Imobiliários - titulo de crédito nominativo de livre negociação (valor mobiliário, pode ser negociado no mercado de capitais), lastreado em créditos imobiliários e que constitui promessa de pagamento em dinheiro. É de emissão exclusiva de companhia securitizadora de crédito imobiliário. Importante salientar que o crédito lastro do CRI pode ser originado pela própria securitizadora ou pode ser cedido pela instituição originadora dos créditos para a securitizadora.

Cédula de Crédito Imobiliário - titulo executivo extrajudicial que representa

5 As Cédulas de Crédito Imobiliário - CCl e as Letras de Crédito Imobiliário - LCl foram instituídas com a Lei 10.931/2004, conhecida como Lei do Patrimônio de Afetação. Trataremos dessa lei no tópico 3.3 - Lei 10.931/2004 e Lei 11.196/2005: o aperfeiçoamento do ambiente regulatório. O instrumento criado por meio da Lei 9.514/1997 foi o Certificado de Recebíveis Imobiliários - CRI.

6 As definições dos instrumentos financeiros foram feitas a partir das informações de FORTUNA, Eduardo. Mercado Financeiro: produtos e serviços. Rio de Janeiro: Qualitymark, 2005; FERNANDES, Antônio A. G. O Sistema Financeiro Nacional Comentado: Instituições Supervisoras e Operadoras do SFN, Políticas Econômicas, Operações Financeiras e Administração de Risco. São Paulo: Saraiva, 2006. 
direitos de créditos imobiliários com fluxo de pagamentos parcelados. Estão autorizadas a emitir as CCI os credores dos créditos imobiliários. Podem representar a totalidade do crédito ou uma fração do mesmo. Não são valores mobiliários, mas títulos emitidos para'facilitar'a transação dos valores relacionados ao crédito imobiliário. As companhias securitizadoras, por exemplo, compram $\mathrm{CCl}$ e as utilizam como lastro para a emissão, no mercado secundário, de CRI, estes sim valores mobiliários.

Letra de Credito Imobiliário - título de crédito que pode ser lastreado por créditos imobiliários ligados ao instituto jurídico tanto da hipoteca quanto da alienação fiduciária de um imóvel. Pode ser garantida por um ou mais créditos imobiliários desde que seu prazo de vencimento não seja superior ao prazo de quaisquer dos créditos imobiliários que lhe sirvam de base.

Debênture - tradicional instrumento de captação de recursos no mercado financeiro. Segundo Fortuna, é um "título emitido apenas por sociedades anônimas não financeiras, de capital aberto, com garantia de seu ativo [...] que as lança no mercado para obter recursos de médio e longo prazos, destinados normalmente a financiamento de projetos de investimentos ou alongamento do perfil do passivo. [...] Garantem ao comprador uma remuneração certa num prazo certo não dando [...] direito de participação nos bens ou lucros da empresa. Correspondem a um empréstimo que o comprador do titulo faz à empresa emissora. É uma forma de financiamento através de empréstimo a longo prazo (Fortuna, 2005, p. 310)."

Letra Hipotecária - títulos emitidos por instituições financeiras autorizadas a conceder créditos hipotecários, mais especificamente as Sociedades de Crédito Imobiliário, os bancos múltiplos com carteira de crédito imobiliário e a Caixa Econômica Federal. A garantia é a caução de créditos hipotecários de que as letras sejam titulares, garantidos por primeira hipoteca. São emitidos vinculados a uma hipoteca.

Cédula de Crédito Bancário - titulo de crédito emitido representando uma promessa de pagamento em espécie decorrente de operação de credito de qualquer modalidade. Pode ser emitida com ou sem garantia real e pode ter pactuado todas as suas características tais como juros, critérios de sua incidência, capitalização, entre outros.

Para operacionalizar a securitização desses recebíveis imobiliários por meio do instrumento Certificado de Recebíveis Imobiliários, CRI, a lei do SFI criou para esse fim 
companhias securitizadoras de créditos imobiliários, e reabilitou para o mercado imobiliário o instituto jurídico da alienação fiduciária.

Como se pode depreender dos principais instrumentos e da forma como foi estruturado, o SFI constitui na verdade um marco regulatório da participação e da operação de instituições financeiras e correlatas no financiamento imobiliário e no mercado de capitais, diferente do SFH, que buscava constituir um aparato estatal para o financiamento de habitação (ainda que, como vimos no capítulo 2, os resultados possam ser questionados)

Após a edição da lei, em 1997, o debate sobre o assunto continuou, visando uma completa implantação do modelo. Em um fórum ocorrido em 1999 organizado pela Câmara Americana de Comércio de São Paulo (AmCham) e pela Universidade de Colorado, o debate apontava claramente qual era o caminho a ser seguido pelo governo brasileiro se quisesse realmente fomentar um robusto mercado de crédito imobiliário:

o Brasil deve fazer da constituição de mercados secundários eficazes o elemento central de suas políticas, estratégias e programas habitacionais. [...] Deve considerar um leque de opções implícitas e explícitas com relação ao apoio do governo. Elas incluem [...] programas de seguro total ou parcial e garantia com respeito à securitização; fornecimento de empréstimos a instituições do mercado secundário; envolvimento patrimonial. [...] Deve-se considerar, no mínimo, a criação de uma instituição de propriedade do governo para segurar diferentes tipos de empréstimos hipotecários ${ }^{7}$ (Kaplan; Mein, 1999, p.36).

Essa instituição de propriedade do governo, citada por esse Fórum, deveria também funcionar como um 'colchão' de liquidez aos recebíveis imobiliários, e assim, de acordo com esse modelo, aumentar a oferta de financiamentos imobiliários em geral e habitacionais em particular. Ou seja, o governo deveria dispor de uma es-

$7 \quad$ On April 8 to April 11, 1999, over eighty respected Brazilian and U.S. business, government, non profit, and academic lea-ders participated in the second Brazil-U.S. Aspen Global Forum on Expanding Primary and Secondary Mortgage Markets and Housing Opportunity, in Sao Roque, Brazil. They included investors, rating agencies, mortgage bankers, originators and servicers, government, quasi government and private sector secondary market participants, and housing policy analysts. Their discussions were vigorous and intense. They cared deeply about finding a way to respond to Brazil's housing priorities in an economically sound and socially conscious manner. While they did not always agree on particulars, they did reach consensus on a broad framework to reform Brazil's housing markets. They also concurred on many immediate strategies and next steps to further Brazil's current efforts to establish effective primary and secondary mortgage markets. 
pécie de fundo governamental com recursos prontos a socorrer o mercado de títulos securitizados caso este apresentasse qualquer problema, minimizando quase totalmente o risco do negócio em nome de um aumento da oferta de financiamento imobiliário. O governo brasileiro também deveria, nesse sentido, buscar a adesão do mercado de capitais para, em princípio, prover recursos em condições e estruturas pré-definidas junto a fundos de pensão e posteriormente a investidores estrangeiros, sempre com o objetivo de fomentar esse mercado. Outros tópicos importantes nesse sentido que foram objeto de recomendação do Fórum foram a padronização dos instrumentos hipotecários e dos critérios de subscrição de hipotecas e a criação de sistemas computadorizados de informações eficientes para fácil acesso por instituições financeiras.

A explosão do mercado de derivativos nos anos 90, o surgimento dos investidores institucionais como participantes fundamentais do mercado de capitais e o crescente uso mundial do instrumento da securitização em quase todos os processos de crédito dão o contexto mundial no qual a adoção de sistemas mais 'sofisticados' para o financiamento habitacional parece a todos os envolvidos um processo de evolução quase natural, longe da excessiva e antiquada regulamentação do estado nas questões de domínio econômico.

Não há como não reconhecer, mesmo em urbanistas pouco acostumados com o discurso econômico, a filiação à nova economia institucional (NEI) nos debates, textos e mesmo na peça legal do SFI. De fato nota-se em alguns estudos acadêmicos a reprodução do discurso da nova economia institucional, que é dominante no âmbito do mercado e do jornalismo econômico, criando uma espécie de senso comum sobre economia e finanças de que "o desenvolvimento de um mercado secundário de letras hipotecárias no Brasil é essencial para atrair capitais para a construção civil e gerar eficiência alocativa de recursos ao setor" (Carneiro; Valpassos, 2003, p. 35).

Sob essa discussão, sob essa base temática é que se formou o debate que formatou a lei do SFI e na qual se processou o debate posterior para sua regulamentação. A afirmação de que o SFH não é capaz de atender o mercado imobiliário, em conjunto com a crença de que o mercado de capitais seria a grande solução para a provisão 
de fundos para o setor imobi-liário foram as bases conceituais do Sistema. O SFI teria então como grande força motriz "o mercado investidor, sendo, portanto, fundamental que o mesmo se sinta atraído pelas operações do SFI, sem o qual sua capacidade de expansão é praticamente nula" (Vedrossi, 2002, p. 18). Dessa forma, o governo brasileiro deveria flexibilizar ao máximo as regras do financiamento imobiliário para que o próprio mercado defina o equilíbrio da oferta e da demanda, já que as decisões dos agentes econômicos no mercado tendem a gerar o equilíbrio, segundo o viés neoclássico.

Ainda sobre o posicionamento do mercado financeiro sobre o papel do crédito imobiliário no desenvolvimento brasileiro, há por parte principalmente dos setores financeiros a construção do argumento de que o desenvolvimento do mercado de financiamento imobiliário na economia deve alcançar o patamar do Chile, do México e também da Espanha8. Para tanto, é necessário que o governo brasileiro, segundo essa agenda, execute medidas que atraiam investimentos do setor privado para o setor de financiamento imobiliário. Note-se que não é uma discussão sobre a melhoria das condições habitacionais nem mesmo uma discussão sobre o aumento do parque residencial, mas sim uma plataforma que objetiva o desenvolvimento do setor de financiamento imobiliário.

Essas medidas se dividem em três grupos:

- melhoria do ambiente institucional, que requer (i) preservação do direito dos investidores (ii) criação de centrais de crédito positivo (iii) padronização de contratos e mecanismos de avaliação de imóveis;

- fortalecimento do mercado secundário por meio da criação de um fundo de liquidez e garantia;

- desburocratização do processo de registro de imóveis por meio da criação de uma base única de registro de imóveis.

A questão que nos interessa aqui é a criação de um fundo de garantia aos financiamentos, que garantiria uma carteira de créditos transacionável no mercado

8 ACCENTURE. Crédito Imobiliário: Propostas para Torná-lo um Efetivo Instrumento Promotor do Desenvolvimento Econômico e Social do País. In: BANCO CENTRAL DO BRASIL. Conferência Internacional de Crédito Imobiliário; nov. 2007, Salvador, Brasil. 
secundário, dando proteção aos investidores. Um fundo de liquidez e garantia poderia ter alguns papéis possíveis, ainda segundo o estudo da Accenture, muito semelhante a estudos do Banco Mundial (ver capítulo 4):

- armazenamento temporário (warehousing): "promover liquidez ao mercado primário através da compra e armazenamento temporário de quantidades elevadas de financiamentos padronizados";

- cobertura por contrato: "assegurar maior acesso à população de mais baixa renda";

- cobertura por carteira: "assegurar mecanismos de garantia dos títulos securitizados através da adoção de seguros de crédito, precificados a mercado".

Ou seja, esse fundo de liquidez daria, na verdade, suporte ao funcionamento do mercado primário de hipotecas, eventualmente comprando e armazenando títulos, financiando seguros com preço de mercado e financiando os contratos de baixa renda, visto que estes contratos, por seu baixo retorno, não interessariam aos investidores. Esse fundo de liquidez e garantia funcionaria, portanto, para que o mercado secundário 'acontecesse' no Brasil, como um fim em si mesmo.

Ainda segundo a Accenture, os recursos necessários para um desenvolvimento expressivo do setor têm que, obrigatoriamente, ter origem no mercado. O estudo então apresenta o valor investido no mercado brasileiro no ano de 2005 a partir das seguintes fontes: ativos dos bancos, investidores institucionais e fundos de investimento. Supondo que todo o potencial dos investidores institucionais e dos fundos de investimento, bem como todo o potencial dos títulos privados e públicos dos bancos fosse investido em títulos de base hipotecária, o estudo chega a um potencial de investimento de 1,8 bilhão, concluindo que o desafio na verdade é "conseguir capturar parte da capacidade de investimento do mercado" (ACCENTURE, 2007, slide 16).

O estudo aponta ainda que "para alcançar daqui a 10 anos a participação do setor na economia comparável ao Chile (329 bilhões em 2005) e considerando todos os recursos disponíveis no SBPE (136 bilhões em 2005)" (ACCENTURE, 2007, slide 17), seria necessário captar no mercado 193 bilhões de reais em investimento, o que, para o 
ano de 2005 - base das informações selecionadas - equivaleria a 9,7\% de todo o PIB nacional 9 .

Não é o caso de questionar a origem dos números e dados e analisar se essa estratégia é ou não adequada para o desenvolvimento do setor imobiliário, especialmente o destinado a imóveis comerciais. Essa análise foge ao escopo dessa tese. O que nos interessa aqui é demonstrar a inadequação dessa arquitetura financeira no equacionamento das grandes necessidades habitacionais do país, tal como é propugnado em fóruns das entidades de classe do setor.

O SFI, portanto, se baseia no conceito da captação de recursos junto ao mercado de capitais por meio da securitização, e busca garantir a segurança jurídica das transações, especialmente quanto à rápida execução da garantia real, por meio da alienação fiduciária. Analisaremos melhor esses dois instrumentos nos tópicos 3.2.1 e 3.2.2.

\subsubsection{Securitização}

Pollock apresenta dados contundentes sobre a riqueza mundial, demonstrando que aproximadamente metade dessa riqueza ou é vinculada ou é oriunda do real estate, ou seja, do mercado imobiliário (Pollock, 1994). Sabe-se também que grande parte da mesma riqueza mundial está alocada em títulos (bonds). O que a securitização imobiliária faz é justamente ligar o mercado de títulos ao mercado imobiliário. A complexidade dessas operações pressupõe, no entanto, um mercado de capitais extremamente bem desenvolvido e tecnologicamente preparado para operações complexas, e também um mercado imobiliário voltado e preparado para operar com esse mercado de capitais.

A securitização em si é feita por meio de inúmeras formas no mercado financeiro atual, sendo a securitização de recebíveis (ou créditos) imobiliários apenas uma delas. 
As securitizações de créditos correspondem à transformação do crédito concedido

em títulos negociáveis de renda fixa. Em busca de recursos para novos negócios, para reduzir riscos de inadimplência ou adequar aos limites de Basiléia, a instituição financeira pode optar por contratar uma securitizadora ou constituir FIDC (Fundo de Investimento de Direitos (reditórios) para negociar seus recebíveis securitizados. [...] Os investidores finais cumprem o papel de financiadores do capital, adiantando ao emissor o valor dos títulos securitizados, recebendo juros e a promessa de liquidação pelo valor de face quando do seu vencimento [...] A securitização de recebíveis é alternativa ao financiamento bancário para empresas não financeiras. [...] O perfil dos recebíveis que dão lastro às securitizações brasileiras ainda é predominantemente relacionado às faturas de vendas (duplicatas) respondendo por $40 \%$ das emissões realizadas no 10 semestre de 2004, seguido dos recebíveis vinculados a financiamentos de automóveis (24\%) e dos recebíveis imobiliários (14\%), que vem aumentando sua participação no mercado de securitizados. (Fernandes, 2006, p. 258) [sem grifo no original].

A lei do SFI, por sua vez, em seu artigo 8, define a securitização de créditos imobiliários como a "operação pela qual tais créditos são expressamente vinculados à emissão de uma série de títulos de crédito, mediante Termo de Securitização de Créditos, lavrado por uma companhia securitizadora". Neste Termo devem estar identificados o devedor e o valor nominal de cada crédito que lastreia a emissão, a identificação dos títulos e a constituição de outras garantias, se for o caso.

Esse processo de estruturação de operações financeiras visa basicamente a alavancagem de'novos' recursos e à dispersão de riscos.

Para reduzir o risco associado à transformação de prazos de suas obrigações de curto prazo em aplicações com prazos de vencimento mais longos, os bancos passam a privilegiar a aquisição de ativos negociáveis, cujo valor de mercado flutua em resposta às oscilações nas taxas de juros [...] essa etapa iniciada no caso inglês na década de 1980 caracteriza-se também pela proliferação das transações não registradas nos balanços (off-balance-sheet) ${ }^{10}$, as quais, no primeiro momento, forneceram aos bancos meios de escapar das diretivas regulatórias ao nível e à qualidade do capital próprio. (Penido de Freitas, 2005, p.25)

10 Operações off-balance são operações financeiras que, embora não sejam registradas nos balanços das empresas, como a própria expressão denota, carregam consigo o compromisso de pagamento futuro, o que implica em risco para as instituições envolvidas. Essas operações são constituídas especialmente por derivativos, garantias a empréstimos, cartas de crédito entre outras. 
processo pelo qual empresas produtivas, bancos, demais empresas financeiras, e governos emitem títulos de dívida, com inúmeras finalidades, envolvendo e interligando, desta foram, os chamados mercados creditício, de capitais, de derivativos (swaps, opções e futuro). Ela é uma modalidade financeira que torna os títulos negociáveis, flexibiliza prazos e taxas de rendimento, adaptável a múltiplos agentes, funcional à administração de riscos, substituta dos empréstimos bancários e, ao mesmo tempo, propícia aos bancos na captação de fundos. Como tal, é peçachave do padrão de riqueza em questão, disseminando-se nas operações nacionais e transnacionais, nos regimes monetário-financeiro e cambial (Braga, 1997, p. 198). [sem grifo no original]

Interessante observar que essa forma de operar, por meio de securitizações de ativos, permitiu que os bancos "escapassem das restrições prudenciais e supervisões de órgãos reguladores e controladores" (Braga, 1997, p. 198), conforme também aponta Penido de Freitas na citação feita acima. A idéia era escapar das restrições, juntando no mesmo 'pacote' dívidas de qualidade duvidosa e devedores de primeira linha. Voltaremos a esse ponto mais adiante.

No entanto, em relação à securitização de ativos imobiliários, o instrumento da securitização é visto por alguns autores e pelo próprio mercado como uma grande inovação, com enorme potencial para injetar liquidez no mercado imobiliário. Alguns estudos desenvolvidos no Núcleo de Real Estate da Escola Politécnica da USP procuram apresentar as principais características desse processo e desses ativos.

Kothari apud Vedrossi descreve o termo securitização como "conversão de ativos de pouca liquidez em títulos mobiliários de grande liquidez, passíveis de serem absorvidos pelo mercado investidor. Esses títulos possuem como lastro os ativos que foram securitizados, tendo suas receitas baseadas no fluxo de caixa proveniente, seja de juros sobre empréstimos, seja de outros recebíveis" (Vedrossi, 2002, p.21). Rocha Lima Jr. apud Vedrossi salienta que a palavra vem do inglês securitization que, por sua vez, vem da palavra securities, que tem o significado de títulos mobiliários. Já Vedrossi apresenta o significado do termo como "emissão de títulos mobiliários com vínculo em um determinado ativo, o ativo passível de securitzação" (Vedrossi, 2002, p.21). 
A possibilidade de captar recursos a custos mais baixos no mercado em comparação com os custos de financiamentos bancários ou outras formas mais tradicionais de captação é apontada como sendo uma das principais características de atratividade da securitização para originadores. É citado que o alargamento da base de investidores, ou seja, um maior número de investidores injetando recursos na compra de um papel, geraria um menor custo de captação desse dinheiro. Segundo Vedrossi, para o originador, uma "das vantagens da securitização é a possibilidade de captação de recursos a custos mais reduzidos podendo gerar um ganho efetivo por parte do originador dos créditos em relação a alternativas de captação existentes" (Vedrossi, 2002, p.21).

A argumentação da captação de recursos no mercado via compra de títulos com lastro imobiliário parece pressupor, a princípio, a impossibilidade de captação de recursos da poupança ou mesmo do FGTS. Pode-se concluir, portanto, que se está tratando de empreendimentos imobiliários que excedem os limites do SFH e que, portanto, estariam fora das ca-racterísticas e do atendimento a essas faixas de renda. Para ilustrar esse aparente paradoxo, no qual a captação de recursos via mercado de títulos e mercado de capitais seria a melhor alternativa em comparação aos fundings da poupança e do FGTS, pode-se utilizar o caso da construtora Klabin Segall, que recentemente foi posta à venda por não conseguir honrar com seus compromissos financeiros. Em matéria do jornal Valor Econômico de 27 de abril de 2009, o jornalista afirma que "segundo fontes do mercado, a empresa sempre foi muito bem como incorporadora, mas faltou experiência financeira. Um dos erros foi usar debêntures para financiar a produção - as empresas do setor costumam usar o dinheiro do SFH, dinheiro proveniente da poupança com custo mais baixo" ${ }^{11}$ [sem grifo no original]. Ou seja, o discurso de que os recursos oriundos do mercado de capitais seriam os mais adequados para financiar o mercado imobiliário apresenta alguns pontos cegos que merecem maior análise.

O que se apresenta, no entanto, como um desdobramento mais adequado para compreender o processo de securitização, especialmente após a crise que eclodiu

11 ENDIVIDADA, Klabin Segall está à venda e já têm interessados. Jornal Valor Econômico, São Paulo, 27 de abril de 2009, p. B6. 
em setembro de 2008, é que "a partir da securitização é criada uma estrutura de capta-

ção de recursos inequivocamente associada à qualidade dos ativos, ou melhor, à qualidade das receitas vinculadas a esses ativos e não à qualidade do tomador dos recursos. A qualidade do tomador de recursos pode ser agregada à operação, mas não de forma obrigatória ou necessária" (Vedrossi, 2002, p. 22).

A estrutura básica de uma operação de securitização pode ser entendida por meio do quadro a seguir.

QUADRO 1

Estrutura básica de uma operação de securitização imobiliária.

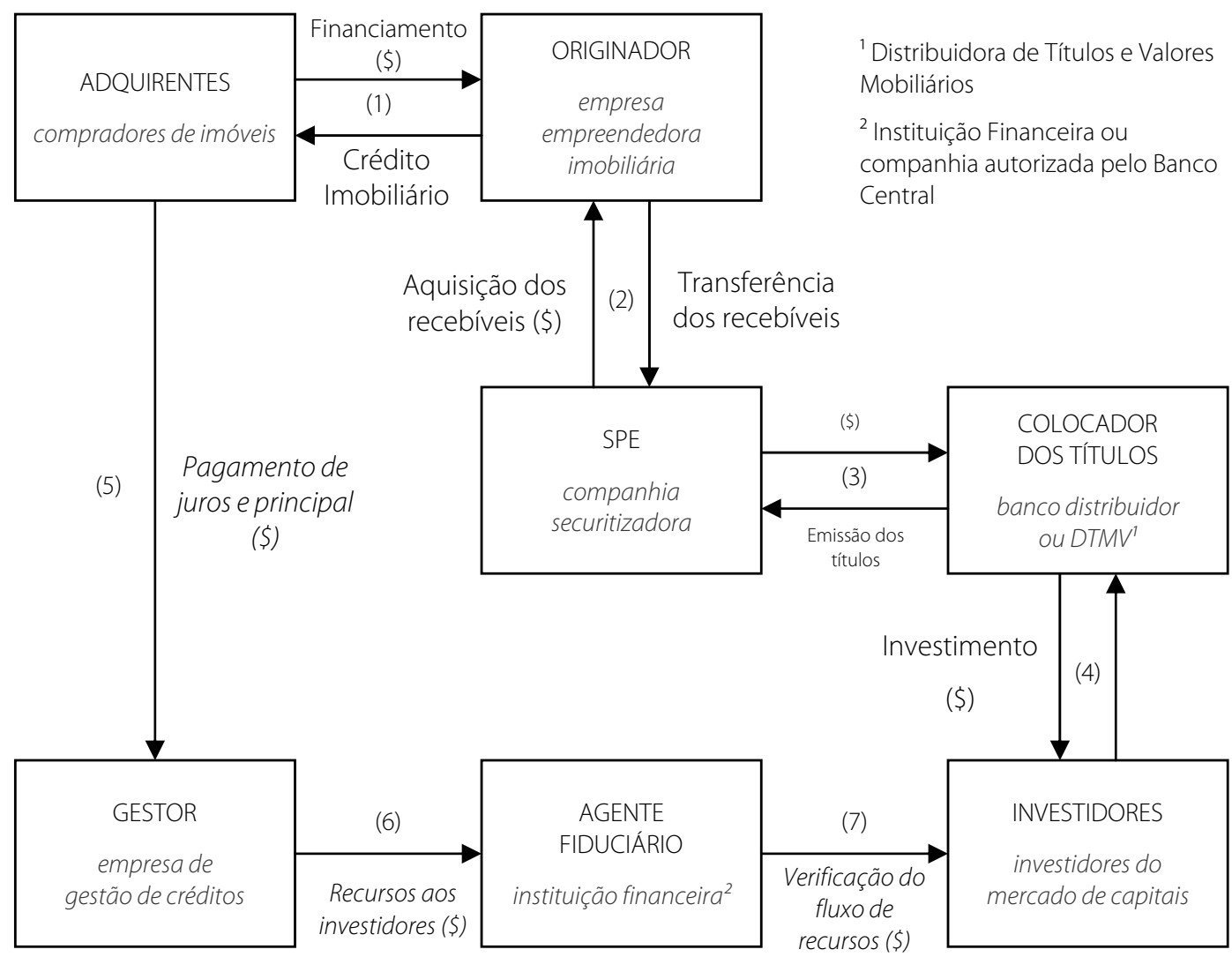

Fonte: Vedrossi, 2002

Todas as peças nesse desenho desempenham papel fundamental no propósito de alavancar recursos. Quem injeta recurso'novo' na cadeia são os adquirentes por meio dos pagamentos mensais (fluxo de pagamentos) visando quitar o financiamento do bem imóvel adquirido ou ainda pagando o aluguel pelo uso de um imóvel. O originador, habitualmente uma empresa empreendedora imobiliária, transfere 
os direitos sobre os recebíveis a uma companhia securitizadora. Essa companhia é quem 'empacota' os créditos/recebíveis e emite títulos que tem como lastro, como base real, os recebíveis oriundos de um empreendimento imobiliário. Os títulos são 'colocados' no mercado por um banco ou distribuidor, devidamente autorizado pela CVM. Nesse ambiente estão os investidores do mercado de capitais que, finalmente, compram os títulos, esperando receber um fluxo de pagamentos de médio a longo prazo, constante, com uma taxa atrativa e com isenção de imposto de renda. Outras peças fundamentais da cadeia são a empresa de gestão de créditos, que recebe o pagamento do principal e dos juros dos contratos de financiamento firmados com os adquirentes, e a instituição financeira que faz o papel de agente fiduciário, que verifica a consistência e distribui o fluxo de recursos aos investidores, fechando assim o ciclo básico da securitização imobiliária.

O instrumento básico da securitização imobiliária no âmbito do SFI são os CRI, Certificados de Recebíveis Imobiliários, títulos que têm vinculação direta a créditos imobiliários e que têm formulação equivalente aos MBS, Mortgage-Backed Securities, título mais conhecido do mercado americano de hipotecas. São títulos de crédito, reunindo "condições de mobilidade e facilidade de negociação típicas do mercado de capitais, possibilitando a criação efetiva de um mercado secundário de negociação desses créditos" (Vedrossi, 2002, p.90).

As características básicas e necessárias à constituição desse processo podem ser descritas então como:

- A identificação do fluxo de caixa futuro esperado desses recebíveis;

- Sua consolidação em pacotes;

- A separação destes de seu originador;

- E sua fragmentação em títulos de investimento a serem oferecidos a investidores.

E para a criação dos títulos há também características básicas que remetem a prérequisitos necessários para que os créditos que estarão na base desses títulos sejam passíveis de se tornarem lastro de operações de securitização.

Dessa forma, para que o mercado brasileiro consiga atender a essas exigências é 
necessário preencher esses requisitos, visto que "o grande objetivo dessas operações

é atrair os investidores, através da oferta de meios de investimento que possuam uma relação atrativa de risco x retorno" (Sando apud Vedrossi, 2002, p.69).

O mecanismo de operação e a lógica que perpassa a arquitetura da securitização, base do sistema de captação de recursos do SFI, é, portanto, a lógica dos produtos financeiros, produtos sofisticados do ponto de vista da formatação, englobando uma série de pré-re-quisitos que devem existir para que sejam atrativos do ponto de vista do investidor:

- geração de fluxo de caixa, sem a qual não há recebível, ou seja, não há crédito passível de ser distribuído;

- qualidade dos recebíveis (qualidade da originação dos créditos, que se divide em: análise do risco de crédito do adquirente, estrutura jurídica da transação original e constituição da garantia imobiliária);

- diversificação do portfólio (dispersão geográfica dos imóveis / não concentração de volume num único crédito / dispersão dos segmentos de mercado em que atuam os adquirentes);

- periodicidade dos pagamentos (fluxo de caixa regular);

- homogeneidade (taxa juros, prazo de amortização, forma de amortização etc.);

- possibilidade de transferência;

- independência em relação ao originador;

- facilidade de comercialização dos títulos.

Dessa forma, todos esses atributos devem ser levados em conta ao se produzir um bem imobiliário que terá como finalidade a captação de recursos junto a investidores. Certamente a produção de uma unidade habitacional, um hotel, qualquer empreendimento imobiliário que for construído tendo como objetivo ser o lastro, a garantia real de uma operação financeira complexa dessa natureza, deve ser estruturada desde o início para atender a esses critérios de enquadramento.

Dentre os critérios de enquadramento mais citados estão o tipo de imóvel, o valor máximo de cada crédito, a relação dívida/valor do imóvel e a capacidade de paga- 
mento do adquirente. $\mathrm{O}$ tipo de imóvel está relacionado com o uso, com a qualidade do bem e com a localização do imóvel. Tendo em vista que o bem é um imóvel, todas essas características podem depreciar ou apreciar seu valor, sendo todas elas fundamentais para a determinação do fluxo de renda futuro.

O valor máximo de cada crédito é um critério relevante para a originação pois, segundo os critérios de risco mais utilizados, não é possível que um crédito seja muito diferente dos demais no mesmo pacote de securitização para não comprometer a homogeneidade desse 'lote', o que aumentaria os riscos.

A relação dívida/valor do imóvel ou loan to value, LTV como é conhecido no meio financeiro, é outra característica muito importante, pois

quanto menor essa relação e, portanto, quanto menor o valor da dívida em relação ao bem em garantia, maior é a segurança do detentor do crédito. [Da mesma forma essa relação] está ligada ao risco de inadimplência do crédito, já que quanto maior a dívida em relação ao valor do bem, maiores as chances de ocorrerem problemas de pagamento com este crédito [...] Em mercados mais desenvolvidos, como o mercado americano, através de programas específicos, o crédito pode ser originado com um valor de dívida equivalente a até 125\% do valor do bem (Vedrossi, 2002, p. 49).

Esses critérios ${ }^{12}$ influenciam obviamente os originadores dos títulos, que ao produzirem recebíveis com essas características repassam para as Sociedades de Propósitos Específicos esses direitos creditórios com muito mais facilidade. Portanto, pela característica de serem absorvidos pelas companhias securitizadoras com mais facilidade, essa arquitetura financeira influencia de maneira decisiva as decisões sobre o que, como e para quem produzir. E, em última instância, quem determina o que é melhor ou não é o investidor, que busca, por sua própria característica, rentabilidade acima ou equivalente a outros investimentos no mercado financeiro.

12 Os critérios utilizados por Vedrossi como sendo os mais importantes são os utilizados e já consagrados pela Fannie-Mae (Federal National Mortgage Association) e pelo Freddie Mac (Federal Home Loan Mortgage Association) empresas privadas regulamentadas pelo governo norte-americano, ambas fazendo parte das Government Sponsored Enterprises, empresas patrocinadas pelo governo. Para um detalhamento do funcionamento do sistema americano de financiamento imobiliário ver ROSSBACH, Anaclaudia C.M. Financiamento Habitacional no Brasil. Dissertação (Mestrado), curso de Pós-Graduação em Economia Política, Pontifícia Universidade Católica, São Paulo, 2005. 
O discurso apresentado por entidades de classe e os estudos acadêmicos do setor, anteriormente citados, levam a conclusão de que sem um forte incentivo por parte do estado, não há como o mercado agir livremente. Os 'anseios' e'necessidades' dos investidores demonstram que só é possível contar com seus recursos se as operações puderem oferecer a segurança que eles já detêm em seus atuais investimentos.

A securitização promoveu mudanças consideráveis no sistema financeiro mundial, especialmente quanto à dispersão dos riscos dos ativos financeiros. A certeza de que esse mecanismo financeiro era uma saída inteligente na dispersão dos riscos do mercado transforma-se em uma crença quase inabalável:

Pode-se afirmar que a securitização das hipotecas reduz o risco de ocorrência de crises sistêmicas no mercado financeiro. A quebra do risco total envolvido em cada operação de financiamento de longo prazo, em três ou quatro grupos de riscos parciais, e sua alocação entre distintas instituições, faz com que o sistema privado, em especial o setor financeiro, esteja mais apto a suportar, sem a necessidade de aporte de recursos públicos, movimentos adversos nos valores de seus ativos (Carneiro; Goldfajn, 2000, p. 17)

Mas, felizmente, essa visão sobre o risco de crises sistêmicas não é consenso. Segundo Belluzzo,

esse fenômeno [crise sistêmica] foi impulsionado pelos hedge funds, que são conhecidos como fundos de proteção, ao permitir que os bancos promovam a diversificação do risco. Cresceram enormemente de 1999 até 2006, contando aproximadamente com 10 mil instituições que oferecem proteção contra os riscos de mercado e de liquidez. Esse enxame de fundos de alto risco (não se perca o leitor na palavra hedge, proteção) colocou sob seu controle um volume assustador de ativos e derivativos, o que elevou substancialmente o grau de alavancagem dos mercados financeiros globais. Os bancos comerciais - os moneys banks - são instituições submetidas a restrições prudenciais e à supervisão dos órgãos reguladores. Desde o primeiro acordo da Basiléia, em 1988, os requerimentos de capital ajustado ao risco de crédito vêm sendo aperfeiçoados e adotados pelos órgãos reguladores da maioria dos países. Ironicamente, as regras da Basiléia empurraram os bancos, sobretudo nos países desenvolvidos, para a 'securitização' de créditos. A idéia era escapar das restrições, juntando no mesmo 'pacote' dívidas de péssima qualidade, como os subprime da vida, e devedores de primeira linha. Em seu zelo prudencial, 
os reguladores jogaram os bancos no colo dos hedge funds, instituições imunes

à regulamentação e à supervisão das autoridades. Esse processo, culminou na erosão da relação risco/capital para o conjunto do sistema financeiro. ${ }^{13}$

A crise atual é um forte indício da correção desses argumentos, conforme vimos no capítulo 1, e desmonta por meio de fatos o edifício teórico dos mercados auto-regulados, especialmente o argumento da não necessidade dos recursos públicos para regular os mercados financeiros.

\subsubsection{Alienação fiduciária}

O instrumento considerado pelo mercado de crédito imobiliário o mais inovador foi mesmo a alienação fiduciária. De fato, se a intenção do governo brasileiro à época era criar um sistema que captasse recursos para sua utilização no próprio mercado, o modelo do mercado secundário de hipotecas, a hipoteca - base do sistema americano e considerada uma das melhores garantias no mundo inteiro - deveria ser considerada como a garantia real por excelência. No entanto a alienação fiduciária foi reinventada como forma de contrapor a lenta execução das operações feitas com hipoteca no Brasil, especialmente na sua execução judicial. Na hipoteca é transferido o direito de posse e o domínio ao mutuário. Mesmo este tendo pago apenas 20 ou 30\% do valor total do financiamento, o tomador do empréstimo já tem a posse e o domínio, ainda que esse domínio seja entregue ao agente financeiro. Na alienação transfere-se apenas a posse e não o domínio. O domínio só é transferido com a liquidação da dívida. Segundo a ABECIP, isso "gera resultados altamente positivos: sustentabilidade jurídica ao processo, maior garantia ao credor e velocidade às operações de crédito imobiliário, além de mais segurança aos agentes financeiros" (ABECIP, 2007). Foi considerada uma importante adequação do arcabouço jurídico visando fornecer ao investidor os instrumentos para uma demanda exeqüível sobre o imóvel que constitui garantia para o empréstimo no caso do devedor deixar de cumprir com suas obrigações.

13 BELLUZO, Luiz Gonzaga. As armadilhas da liquidez. Jornal Valor Econômico, São Paulo, 21 de agosto de 2007. 
Isso porque a alienação fiduciária, sendo considerada uma garantia real do bem que está sendo adquirido, transfere para o banco a propriedade do imóvel, tendo o mutuário somente a posse e não a propriedade. Segundo o Art. 22 da Lei do SFI, a alienação fiduciária "é o negócio jurídico pelo qual o devedor, ou fiduciante, com o escopo de garantia, contrata a transferência ao credor, ou fiduciário, da propriedade resolúvel de coisa imóvel". Ao registrar o contrato no cartório de registro de imóveis, constituise automaticamente a propriedade fiduciária. E com a constituição da propriedade fiduciária, há um desdobramento da posse, com duas figuras, a do fiduciante possuidor direto e a do fiduciário possuidor indireto. Ainda segundo a Lei 9.514/1997, Art. 25, "com o pagamento da dívida e seus encargos, resolve-se, nos termos deste artigo, a propriedade fiduciária do imóvel." Porém, se "vencida e não paga, no todo ou em parte, a dívida e constituído em mora o fiduciante, consolidar-se-á, nos termos deste artigo, a propriedade do imóvel em nome do fiduciário" (Art. 26).

O fato da legislação brasileira não permitir a execução de um bem dado em garantia quando esse bem é bem de família, ou seja, é o único imóvel da família, constitui um sério entrave para o desenvolvimento de um mercado de hipotecas no país, segundo os especialistas. Em um curso promovido para países 'emergentes' na sede do Banco Mundial em Washington ${ }^{14}$, em 2003, destinado a traçar as características básicas necessárias para o desenvolvimento de mercados primários e secundários de hipotecas nos países em desenvolvimento, os organizadores apontaram essa questão do bem de família no Brasil como um exemplo negativo, como um dos fatores que retardam, ou mesmo impedem, o florescimento do mercado de hipotecas, visto que a recuperação do crédito se torna muito difícil, muitas vezes mesmo impossível. Além disso, o processo judicial, por conta das características do poder judiciário no país, é moroso para os fins de recuperação do crédito investido.

As principais comparações apresentam prazos de retomada que opõem um imóvel com garantia hipotecária a um imóvel com garantia fiduciária: o primeiro podendo levar 10 anos para sua conclusão enquanto que a alienação fiduciária, já que não exige processo judicial e pode ser feita por meio de processo administrativo, pode partamento de Operações e Políticas do Setor Financeiro do Banco Mundial de 10 a 13 de março de 2003. 
durar aproximadamente 6 meses para que o imóvel seja retomado. Para o investidor, essa diferença de prazo na recuperação do crédito em caso de inadimplência (default) é a diferença entre investir ou não seus recursos no mercado imobiliário.

O próprio cartório de registro de imóveis e o cartório de títulos e documentos conduzem, em conjunto com o banco ou agente financeiro, o processo de retomada do imóvel, por meio de intimações ao devedor para a quitação da dívida e, no caso de não ser quitado, o imóvel é leiloado, e o recurso retorna ao credor.

Mais uma vez, a lógica é toda financeira, visto que o beneficiário adquiriu, não um bem imóvel, mas sim um 'dinheiro', um recurso, um crédito para comprar um bem imóvel.

\subsection{Lei $n^{\circ} .10 .931 / 2004$ e Lei $n^{\circ} .11 .196 / 2005$ : o aperfeiçoamento do ambiente regulatório}

Apesar da boa repercussão no âmbito do mercado de crédito imobiliário da lei que instituiu o SFI, havia ainda, segundo as entidades que representam o setor, requisitos imprescindíveis para o pleno desenvolvimento do coração do sistema, a securitização. Entre outras mudanças, era necessária uma base legal que garantisse o pleno cumprimento das leis, normas operacionais e contratos, que pudessem enquadrar o risco jurídico como mínimo e previamente mensurável, especialmente no caso da retomada das garantias reais. Isso significava a introdução da alienação fiduciária de bem imóvel no Código Civil, disciplinando inclusive a execução da garantia. Além disso, a desoneração tributária ainda era uma solicitação não contemplada na lei do SFI.

Visando suprir lacunas para o pleno funcionamento do SFI, em 2004 foi editada a Lei no. 10.931, conhecida como a Lei do Patrimônio de Afetação, mas que continha, além desse instituto, o instituto do Valor do Incontroverso, bem como novos títulos de crédito, tais como as Cédulas de Crédito Imobiliário, CCI, Letras de Crédito Imobiliário, LCl e Cédulas de Crédito Bancário, CCB. Na lei consta o aperfeiçoamento 
de vários mecanismos que estavam em vigor, especialmente na Medida Provisória $n^{\circ}$. 2.221/2001, que tratava do patrimônio de afetação e na Medida Provisória nº 2.223/2001, que instituiu os títulos de credito de ativos imobiliários, a CCl e a LCl${ }^{15}$.

A lei consolidou a base legal do setor imobiliário-financeiro e reforçou as garantias a financiadores e compradores, reforçando o arcabouço jurídico necessário à expansão do setor imobiliário no modelo do SFI.

O instituto do Patrimônio de Afetação segrega os ativos de um empreendimento dos outros ativos da empresa promotora, de forma que os recursos financeiros de um determinado empreendimento ficam apartados do resto dos ativos da empresa construtora e incorporadora, com escrituração contábil também apartada, evitando que o comprador de um determinado empreendimento venha a ser prejudicado pela falência total da empresa, como no caso da empresa Encol, que quebrou nos anos 90 e deixou muitos empreendimentos sem finalização mesmo com apartamentos já vendidos. O caso da Encol foi paradigmático no setor, pois em 1994 havia mais de 600 obras inacabadas e, a partir de 1995, a derrocada financeira da empresa levou-a a decretar a concordata em 1999. Mais de 42 mil clientes que já haviam pagado total ou parcialmente seu imóvel ficaram sem a entrega dos apartamentos. O episódio abalou a confiança do mercado, tanto do lado da oferta quanto do lado da demanda. O que o patrimônio de afetação trouxe de inovação foi justamente apartar a contabilidade da empresa construtora e incorporadora da contabilidade do empreendimento.

Já o Valor do Incontroverso procura viabilizar o pagamento das prestações cujos contratos estão sendo questionados judicialmente. Trata-se de suspensão de pagamento do financiamento imobiliário restrito ao que está sendo questionado judicialmente e não em relação a todo o contrato. Buscou-se acabar com a chamada 'indústria das liminares': "o mutuário utiliza a justiça para não pagar os encargos, entrando com pedido de liminar, com a alegação de algum tipo de irregularidade no contrato. Mesmo sem qualquer fundamento, os adquirentes obtinham a liminar e, com isso, 
A consolidação da lei deu maior segurança aos investidores e facilitou as operações de venda de carteiras e transferência de ativos para securitizadoras. Também incentivou a redução de custos na emissão de títulos de crédito ao criar a Cédula de Credito Imobiliário $(\mathrm{CCl})$ porque a transação passou a não exigir a transferência da titularidade nos títulos de crédito. Anteriormente, qualquer compra de crédito exigia o registro em cartório de cada contrato, com todos os custos decorrentes. A utilização da CCI facilita as transações, por ser um ativo que pode ser registrado em um sistema de liquidação, facilitando as negociações no mercado secundário.

Após a edição da Lei n. 10.931, a Medida Provisória n. 255, posteriormente convertida na Lei $n^{\circ} .11 .196 / 2005$, consolidou outros pontos fundamentais para o setor imobiliário. Constituiu-se um regime especial de tributação do patrimônio de afetação, uma antiga reivindicação do setor, e foi instituído também um regime especial com alíquota única de $7 \%{ }^{16}$ para incorporações. Consolidou-se também o emprego de índices de preço ou índices financeiros nos contratos de compra e venda imóveis desde que tenham prazo acima de 36 meses. As mesmas condições foram estendidas às operações dos agentes financeiros, o que abriria caminho para a padronização de contratos e títulos, condição para facilitar a securitização dos títulos, conforme a agenda de organismos multilaterais de fomento, tal como o Banco Mundial.

Vários pontos relativos a ajustes financeiros merecem olhar especial do ponto de vista da modelagem financeira, especialmente em relação à tributação, redução nos impostos, sistema de incentivo à compra de imóveis por meio de dedução do valor pago em juros do imposto de renda (rebate no IR) e redução da Cofins. Importante salientar que o setor de construção civil strictu sensu sempre defendeu a bandeira de redução, e até isenção, de impostos relativos à produção.

16 A Medida Provisória n460/2009, que, trata, entre outros assuntos, do patrimônio de afetação de incorporações imobiliárias, dispõe sobre o tratamento tributário a ser dado às receitas mensais auferidas pelas empresas construtoras nos contratos de construção de moradias firmados dentro do Programa Minha Casa, Minha Vida - PMCMV, apresenta, em seu art. 10, uma nova redação para os arts. 40 e 80 da Lei no 10.931/2004, diminuindo essa alíquota única para 6\%: "Para cada incorporação submetida ao regime especial de tributação, a incorporadora ficará sujeita ao pagamento equivalente a seis por cento da receita mensal recebida" (MPV nº 460/2009, Art. 10) 
Além disso, a Medida Provisória n. 255 abriu a possibilidade de se adotar a previdência privada como instrumento colateral de garantia nos financiamentos imobiliários. Dessa forma, os ativos não se misturam com os ativos da seguradora, podendo ser oferecidos como garantia de financiamentos imobiliários. No texto da lei $n^{\circ}$. 11.196/2005, art. 78, §10: "No caso de falência ou liquidação extrajudicial da entidade aberta de previdência complementar ou da sociedade seguradora, o patrimônio dos fundos não integrará a respectiva massa falida ou liquidanda".

Outra medida foi a permissão da utilização de cotas de fundo de investimento como garantia em contrato de locação. A intenção do legislador era, de acordo com a exposição de motivos da peça legislativa, minimizar o problema do déficit habitacional por meio da viabilização do mercado de locação ${ }^{17}$.

AMP alterou ainda a tributação dos ganhos de capital auferidos na venda de imóveis. A faixa até 35 mil tornou-se totalmente isenta. E se, na venda de um imóvel, dentro do prazo de 180 dias, o valor do negócio for novamente aplicado na aquisição de um outro imóvel residencial, o ganho de capital estará isento do Imposto de Renda. Há ainda uma tabela prevendo redução gradativa da parte do valor tributado. No texto da Lei n’.11.196/2005, art. 39: "Fica isento do imposto de renda o ganho auferido por pessoa física residente no País na venda de imóveis residenciais, desde que o alienante, no prazo de 180 (cento e oitenta) dias contado da celebração do contrato, aplique o produto da venda na aquisição de imóveis residenciais localizados no País".

Também instituiu a isenção do Imposto de Renda das pessoas físicas adquirentes de cotas de fundos imobiliários, igualando o tratamento tributário das Letras Hipotecárias, dos Certificados de Recebíveis Imobiliários, das Letras de Crédito Imobiliário, o que seria também um incentivo do lado da demanda, buscando fomentar o mercado imobiliário, tornando os títulos mais atrativos para o público investidor, fomentando a procura e incentivando a sua emissão.

17 Art. 88. As instituições autorizadas pela Comissão de Valores Mobiliários - CVM para o exercício da administração de carteira de títulos e valores mobiliários ficam autorizadas a constituir fundos de investimento que permitam a cessão de suas quotas em garantia de locação imobiliária. As entidades abertas de previdência complementar e as sociedades seguradoras poderão, a partir de 10 de janeiro de 2006, constituir fundos de investimento, com patrimônio segregado, vinculados exclusivamente a planos de previdência complementar ou a seguros de vida com cláusula de cobertura por sobrevivência, estruturados na modalidade de contribuição variável, por elas comercializados e administrados. 
Também a aprovação da nova lei de falências em 2005 contribuiu para aumentar a segurança do setor imobiliário-financeiro, pois os créditos com garantia real ficaram no segundo posto na escala de prioridades por ocasião da falência.

Segundo a ABECIP "O sistema financeiro imobiliário ganha espaço, enfim, para decolar, sustentado por um arcabouço jurídico seguro apoiado em três pilares, definidos pela Lei no. 10.931. Estes pilares são o patrimônio de afetação, a alienação fiduciária de bem imóvel e a regra do incontroverso. Sem estas garantias, temia-se que o SFI, criado no final da década passada pela Lei no. 9.514, de novembro de 1997, continuasse relativamente travado, em especial por causa da insegurança jurídica que afastava agentes financeiros, incorporadoras e mutuários" (ABECIP, 2004-B, p. 03). Essa insegurança refere-se especialmente à segurança jurídica do retorno do crédito concedido, caso que a alienação fiduciária consegue equacionar, visto que a retomada do imóvel é muito mais rápida e simples em comparação ao processo de retomada de imóvel hipotecado. Além disso, ainda que a alienação fiduciária constasse da lei de criação do SFI, o fato de não constar no Código Civil, tal como foi instituída na Lei no. 10.931, trazia uma insegurança jurídica quanto à sua aplicabilidade. As mudanças no instrumento da alienação fiduciária incluíram ainda aplicação da fidúcia em terrenos da marinha e em terrenos sem construção.

\subsection{Resoluções do CMN e Instruções Normativas da SRB: regras e parâmetros para a operação do mercado de títulos de crédito imobiliário}

O Conselho Monetário Nacional, como é sabido, é um órgão colegiado normativo do sistema financeiro nacional, "responsável por expedir normas gerais de contabilidade e estatística [..] coordenar as políticas monetária, de crédito, orçamentária e fiscal, a dívida pública interna e externa" (Fernandes, 2006, p.25). Dessa forma, todos os instrumentos criados pelas leis no. 9.514 e no. 10.931, ao operar como instrumentos de investimento no âmbito do mercado financeiro, devem ser regulamentados pelo CMN. 

para a operacionalização do SFH. Atualmente, o CMN considera operações de financiamento habitacional no âmbito do SFH as operações de financiamento para aquisição de imóveis novos e usados, para produção de imóveis e para aquisição de material de construção.

Atualmente as condições básicas do SFH, dadas pela Resolução CMN no 3.347 são as seguintes:

- Valor dos financiamentos não superior a 245 mil;

- Limite máximo de avaliação do imóvel financiado em 350 mil;

- Custo efetivo máximo em 12\%, excluindo-se seguros e tarifa mensal do contrato $^{18}$.

Mas, alem dessa definição, também considera como operações de financiamento habitacional no âmbito do SFH:

- Cédulas de crédito imobiliário;

- Cédulas hipotecárias representativas de operações de financiamento;

- Letras de crédito imobiliário;

- Letras hipotecárias e os depósitos interfinanceiros imobiliários, garantidos ou las-treados por operações de financiamento habitacional;

- Certificados de recebíveis imobiliários de emissão de companhias securitizadoras de créditos imobiliários;

- Cotas de fundos de investimento imobiliário e de fundos de investimento em direitos creditórios, cujas carteiras sejam constituídas por financiamentos habitacionais ou por direitos creditórios;

- Financiamentos na chamada 'faixa especial' ${ }^{19}$;

- Créditos de fundos do extinto BNH (FAHBRE e FESTA);

- Créditos do FCVS;

- Créditos das dívidas novadas do FCVS;

18 No contexto do Programa Minha Casa Minha Vida, a Resolução CMN no. 3.706 alterou a Resolução CMN nº 3.347 elevando o valor máximo do imóvel para $R \$ 500$ mil e o valor financiável para $\mathrm{R} \$ 450$ mil.

19 Faixa especial era a designação encontrada pela CMN para operações que estavam acima da faixa inicial de exigibilidade durante a vigência da Resolução CMN no. 2.458, de 18 de dezembro de 1997. 
- Projetos de investimento de concessionárias privadas do setor de saneamento; e

- Estudos técnicos para estruturação de modelos de parceria entre setor público e setor privado.

A Resolução CMN nº. 3347 é a que atualmente regulamenta o SBPE, ditando quais são as normas de exigibilidade da poupança, criando as regras necessárias à operacionalização do SFH. Portanto, quem normatiza as condições da operacionalização do SFH, determinando o que está incluído ou não no sistema, o que pode ser considerado uma operação de financiamento habitacional do SFH, é o Conselho Monetário Nacional.

Em relação especificamente à regulamentação do CRI e de outros instrumentos do SFI, em junho de 1998, por meio da Resolução n. 2.517, o CMN reconheceu os CRI, tal como apresentados na lei do SFI, como valores mobiliários, ou seja, títulos que poderiam ser então transacionados no mercado de títulos como qualquer outro título financeiro. Na seqüência, a Resolução no. 2.518 facultou a aplicação de recursos das entidades abertas e fechadas de previdência privada, sociedades seguradoras e sociedades de capitalização em CRI. E ainda a Resolução nº. 2519, consolidando as normas sobre o direcionamento de recursos captados via depósito de poupança pelas entidades integrantes do SBPE, autorizou o cômputo de títulos de companhias de securitização no cálculo da exigibilidade, ainda que com um limite para essa aplicação.

Um ano depois, a Resolução no 2.623 incluiu textualmente os CRI no cômputo do percentual exigido de financiamentos habitacionais com o recurso da poupança, com um limite de 10\%. Já em 2001, a Resolução n 2.967 permitiu às sociedades seguradoras, sociedades de capitalização e entidades abertas de previdência complementar aplicarem até $80 \%$ dos recursos das reservas, das provisões e de seus fundos em CRI.

Em 2002, o CMN, por meio da Resolução nº. 2.922, permitiu às entidades fechadas de previdência complementar, um dos principais investidores institucionais do país, a aquisição de até 100\% de uma mesma série de CRI, desde que classificada como 
baixo risco de crédito por pelo menos duas agências classificadoras de risco em funcionamento no país.

Ainda em 2002, as emissões de CRI ganham um outro 'cliente'fundamental para seu crescimento, o FGTS. O Conselho Curador do FGTS aprovou a Resolução no. 390, permitindo ao FGTS adquirir CRIs, desde que lastreados em financiamentos para empreendimentos habitacionais em fase de produção ou na planta. O CCFGTS aprovou ainda a aplicação de recursos do FGTS na aquisição de CRIs que estivessem vinculados a operações de saneamento.

Essa série de resoluções do CMN e do CCFGTS, editadas praticamente ano a ano desde 1998, mostram que os CRI e outros títulos da mesma natureza foram ganhando espaço no mercado de capitais, ampliando sua participação e ampliando a participação na captação de recursos que seriam destinados inicialmente para o atendimento a baixa renda, como o FGTS.

Pelas recentes notícias, o objetivo de fazer dos CRI um instrumento de captação de recursos para o mercado parece estar sendo conquistado:

As emissões de títulos securitizados de crédito imobiliário voltaram a apresentar forte crescimento neste ano. O volume de operações registradas na Comissão de Valores Mobiliários (CVM) até o fim de julho é de $R \$ 2,77$ bilhões, superior ao patamar atingido em 2005, até então o melhor ano do setor (R\$2,34 bilhões). Somente a Cibrasec, uma das maiores securitizadoras, emitiu R\$1,23 bilhão em Certificados de Recebíveis Imobiliários (CRI), quase o triplo do total lançado pela companhia ao longo de todo o ano passado (R\$457 milhões). O montante equivale a mais de 60\% dos títulos lançados por todo o mercado de CRI. [...] O grande comprador desses papéis ainda são os grandes bancos, que precisam de CRI para cumprimento da exigibilidade de crédito imobiliário do Banco Central..$^{20}$ [sem grifo no original]

E ainda,

Os ativos financeiros com lastro imobiliário, que já atraíam pela isenção fiscal sobre o retorno, tornaram-se ainda mais interessantes aos olhos do investidor private como alternativa à menor remuneração das tradicionais aplicações de renda 
fixa, como títulos públicos ou fundos Dl, na esteira da redução do juro básico. [...]

O Itaú Unibanco partiu para a oferta agressiva de ativos imobiliários, afirma Celso Scaramuzza, diretor-executivo do banco responsável pelo private. "Esse mercado de ativos imobiliários vai crescer muito até porque os instrumentos tradicionais de renda fixa sofreram com a redução da Selic", diz. No banco, o segmento cresce 20\% ao ano, conta o diretor, sem, contudo, detalhar os volumes. [...] Fabio Nogueira, diretor da Brazilian Finance \& Real Estate (BFRE), ressalta que o momento hoje é bastante propício para o crescimento do mercado imobiliário. Ele cita a redução do juro - que, na sua visão, não tem nada de artificial -, a forte necessidade de recursos do setor para projetos bons - "vivemos a grande oportunidade dos últimos 40 anos de acabar com o déficit habitacional" - e a estabilidade de preços dos imóveis. [...] O CRl é outro papel que chama a atenção do investidor de alta renda pela boa remuneração. No entanto, de acordo com o advogado Carlos Eduardo Ferrari, sócio do escritório Lobo \& de Rizzo, o grosso das emissões não vai a mercado. Em 2008, informa, mais de 60\% das colocações foram privadas, ou seja, não passaram pelo crivo da Comissão de Valores Mobiliários (CVM). E os grandes compradores são os bancos, que usam o instrumento para cumprir a exigibilidade do financiamento habitacional. ${ }^{21}$ [sem grifo no original]

A nota técnica que acompanha a Resolução no. 3155, de 17 de dezembro de 2003, apresenta o CRI como um instrumento "cujo sucesso de colocação junto ao público investidor já foi comprovado no exterior", visto que "como são títulos emitidos por securitizadoras, assemelhar-se-iam aos 'mortgage backed securities' (MBS) americanos, emitidos por empresas como Fannie Mae e Freddie Mac, que contam com liquidez e volume de negócios bastante elevados, comparáveis aos dos títulos do tesouro dos EUA".

O esforço do BACEN e do CMN para viabilizar a emissão dos CRI após a sanção da lei do SFI pode ser melhor compreendido no mecanismo criado para garantir a aquisição dos CRI:

Ele pode ser melhor entendido por meio do exemplo a seguir, que parte da situação em que o incorporador obtém financiamento, junto a uma instituição do Sistema Brasileiro de Poupança e Empréstimo (SBPE), para a produção de unidades habitacionais. Tais unidades são ofertadas ao público, que, em sua maior parte, adquire o imóvel parceladamente. Esses pagamentos parcelados, ou recebiveis imobiliários, são então vendidos para uma companhia securitizadora de créditos imobiliários, que, por sua vez, oferta em mercado CRI lastreados nos créditos assim adquiridos.

21 BELLOTTO, Alessandra. Tijolo de papel. Jornal Valor Econômico, São Paulo, 30 de junho de 2009. 
Uma instituição financeira também integrante do SBPE garante a aquisição dos

CRI, que, dessa forma, conta com instrumento de liquidez que facilita sua colocação junto a investidores, em particular, os assim chamados institucionais, como entidades abertas e fechadas de previdência complementar e companhias seguradoras. A garantia de aquisição se dará em datas e a preços pré-estabelecidos, desde que respeitado o prazo mínimo correspondente a $20 \%$ do prazo total do certificado, e somente poderá ser exercida após os certificados terem sido ofertados junto ao público, por intermédio de bolsa de valores ou mercado de balcão. Em contrapartida à garantia de aquisição, as instituições financeiras poderão computar, no direcionamento dos depósitos de poupança de que trata a Resolução 3.005, de 30 de julho de 2002, até 35\% do valor das cartas de garantia de aquisição. ${ }^{22}$

Ou seja, a liquidez necessária para o funcionamento dos CRI se daria tendo como base o SBPE, com recursos captados na poupança a baixo custo para os investidores. Dessa forma, a aposta de que o sucesso do instrumento significaria a entrada de novas fontes de recursos para um setor atrasado ou ainda totalmente dependente da captação da poupança e do FGTS parece contraditória, visto que são justamente esses os recursos que se mostram fundamentais para que o investimento seja atrativo e faça girar o ciclo dos investimentos.

A Instrução Normativa n.487 da Secretaria da Receita Federal (atualmente Secretaria da Receita do Brasil - SRB) e a Instrução Normativa n. 414 da Comissão de Valores Mobiliários (CVM) regulamentaram os investimentos de pessoas físicas nos CRI, reduzindo o valor mínimo, até então de 300 mil, para aplicação nesses papéis. A intenção foi estimular o interesse dos investidores pelos papéis com garantia imobiliária, desenvolvendo o mercado desses títulos e assim aumentando o volume de recursos destinados ao financiamento imobiliário.

Os títulos bancários tais como CRI, Letras e outros são introduzidos pela norma como elegíveis para o cumprimento da exigibilidade dos recursos de poupança, com alguns li-mites para sua utilização. No entanto, ainda assim, o que se verifica é que aproximadamente 39\% dos recursos captados em poupança podem ser aplicados nesses títulos, que são a base de um processo de securitização. Se aproxima-

22 Ver Nota Técnica BACEN relativa à Resolução CMN no. 3.005. 
damente $26 \%$ das operações podem ser ${ }^{23}$ aplicadas em títulos creditícios, somadas

a 20\% que podem ser aplicadas em operações a taxas de mercado, chega-se a um percentual de quase $40 \%$ dos recursos captados em poupança que podem ser utilizados na montagem e operação de securitizações em um mercado secundário. Ainda que as operações do SFH preencham as condições da le-gislação em vigor (valores unitários de financiamento não superiores a R\$245.000,00, limite máximo de avaliação do imóvel não ultrapassando R\$350.000,00, bem como custo efetivo máximo de $12 \%$ ao $a_{n}{ }^{24}$ ), o custo de captação desse recurso é muito baixo, o que propicia ganhos significativos nas operações, desde a captação até a movimentação no mercado secundário.

\section{$3.5 \mathrm{SFI}$ e o SFH}

Ainda que o SFI tenha sofrido todo esse aprimoramento, recebendo suporte legislativo, e com um ambiente macroeconômico mais propício, para a ABECIP, o modelo brasileiro é 'simplório' pois ainda tem a caderneta de poupança como grande funding das operações de credito imobiliário. A intenção do mercado de crédito imobiliário seria, segundo seus documentos oficiais, ter um modelo de crédito imobiliário integrado com o mercado de capitais, que reunisse além de bancos e compradores, grandes investidores, como é o caso dos fundos de pensão e seguradoras, que poderiam adquirir CRI para compor suas reservas técnicas.

O argumento é, mais uma vez, de que o estado está falido, não há mais como contar com o estado para investir em crédito, de que é preciso buscar recursos em outras fontes para a construção, encontrando eco em vários discursos oficiais de entidades de classe e mesmo em trabalhos acadêmicos.

\footnotetext{
23 Resolução CMN n. 3347 - Art.5․ O valor total das Letras de Crédito Imobiliário, das Letras Hipotecárias, dos Depósitos Interfinanceiros Imobiliários, dos Certificados de Recebíveis Imobiliários, das Cotas de Fundos de Investimento Imobiliário e de Fundos de Investimento em Direitos Creditórios, de 35\% dos recursos das cartas de garantia de aquisição de CRI, não pode exceder $50 \%$ do limite previsto na alínea 'a' do inciso I do artigo $1^{\circ}$.

24 Não incluso nesse valor os custos de seguro e valor de tarifa mensal cobrada pelos agentes financeiros a titulo de custo de administração.
} 
O documento da CBIC que trata do balanço do ano de 1996, baseado no documento "Diretrizes para a Reformulação do Sistema de Financiamento da Habitação", elaborado pelo Sinduscon de São Paulo, Minas Gerais e Goiás e pelo Secovi SP, afirma que "com a falência do estado, que há muito tempo perdeu sua capacidade de investir, recai sobre o sistema financeiro privado a responsabilidade de prover, alternativamente os recursos necessários para viabilizar financiamentos de longo prazo ao setor" (CBIC, 1996, p. 20).

No entanto, não é o que o vertiginoso aumento do número de financiamentos, tanto no SBPE quanto no FGTS demonstra. Toda a mudança institucional promovida por meio da Lei no. 10.931 e pelas Resoluções do CMN fizeram com que o SFH tivesse um desempenho excepcional para os padrões dos anos 90 e mesmo de grande parte dos anos 80 .

Mas a captação de recursos de grandes investidores, investidores institucionais, entre outros, para serem funding de novos empreendimentos habitacionais parece não se confirmar. O Núcleo de Real Estate da POLI-USP, que acompanha sistematicamente o desempenho das empresas de real estate que têm capital aberto na bolsa, analisou, no final do ano de 2007, quinze ofertas primárias de ações (OPA) dessas empresas: "selecionando as quinze OPAs que aconteceram entre set05 e abril07, as empresas objeto multiplicaram seu capital de giro, na media, por quatro. [...] O próprio volume de capital obtido na bolsa, com as oscilações sofridas após o período, parecem mostrar que os recursos advindos das aberturas não são tão sustentáveis quanto poderiam ser" (Lima Jr., 2007)

Nem mesmo quando o país atinge o cobiçado investment grade ampliou-se sobremaneira os investimentos em real estate:

o impacto positivo que se atribuiria ao setor se desvanece, caindo os preços das ações muito mais acentuadamente que o lbovespa, refletindo um descrédito do mercado de que as ações das corporações de real estate listadas possam se sustentar nos valores que vinham sendo praticados. É sempre bom ressaltar que preço de transação de uma ação, fora movimentos especulativos, reflete a percepção de valor prevalente do mercado (Lima Jr.; Alencar, 2008, p. 4). 
Essa instabilidade inerente ao mercado de capitais obviamente acompanha as empresas imobiliárias e influencia sobremaneira investidores em geral, esses que seriam o foco dos títulos creditícios de base imobiliária. Dessa forma, a crítica de que o FGTS e o SBPE seriam fundos instáveis, dependentes do cenário macroeconômico do país, não consegue se sustentar, visto que a alternativa de captação de recursos junto ao mercado de capitais, ao contrário de resolver o problema, consegue aprofundar essa característica de instabilidade de fluxo de recursos.

Especialmente quanto ao mercado de real estate conhecido como novo mercado, resultado das OPA de 2005 a 2007,

é possivel que haja ainda um caminho dificil a percorrer, até que as empresas se ajustem à sua nova escala [...] desencaixando os terrenos internados nos land bank que rendem zero. Ainda há escuridão adiante sobre como os empreendedores redesenharão a oferta para encaixar os custos de produção que sobem num gradiente maior do que a renda do público alvo. [Dessa forma] é fácil reconhecer a fragilidade dos documentos de análise da qualidade de investimentos nos quais se apóiam as ofertas de negócios produzidas por empresas brasileiras, o que, certamente, não serve de estímulo a que capitais conservadores [até mesmo de investidores institucionais brasileiros] promovam a aventura de aqui se ancorar (Lima Jr; Alencar, 2008, p. 9).

Investidores institucionais dessa forma, apesar da melhoria no volume de emissão de LCl e CRI, oriunda principalmente da queda na taxa de juros, tendem a preferir investimentos mais simples e de risco mais facilmente mensurável. Nesse sentido existe a análise de que "essa característica comportamental dos investidores em CRI's [foi o] que determinou um menor desenvolvimento dos CRI's lastreados em recebíveis residenciais (ou habitacionais) pulverizados, de forma contrária àquela almejada na Exposição de Motivos da Lei do SFI, se comparados aos CRl's lastreados em créditos corporativos (ou comerciais)" (Alves, 2005, p. 62).

Os prospectos de CRI que estão publicados para consulta na CETIP, balcão eletrônico de transação de títulos mobiliários, demonstram que boa parte das ofertas públicas de CRI se dão sobre empreendimentos imobiliários comerciais. Além disso, segundo análise de monografia do Instituto de Economia da UFRJ "OS CRI's financiam, em sua 
quase totalidade, a construção de centros de distribuições e unidades fabris, terminais logísticos, prédios de escritó-rios comerciais, shopping-centers e hospitais - ou seja, financiam a componente imobiliária puramente comercial e industrial de projetos de investimento de qualquer espécie" (Alves, 2005, p. 29).

A idéia de que se é bom para os bancos e para os mercados é bom para quem vai tomar o crédito nem sempre corresponde aos fatos, visto que a lógica financeira que perpassa a atividade bancária e financeira é a lógica de valorização do capital e não a lógica do acesso a um bem, e muito menos a lógica de universalização de direitos.

Não é possível se pensar uma política habitacional e mesmo um plano de execução dessa política que baseie sua captação de recursos em recursos oriundos do mercado secundário, como querem alguns autores, pela própria natureza desse mercado.

O próprio PLANHAB, ao estudar a captação de recursos para a implementação da Política Nacional de Habitação, apresenta as limitações da captação de recursos junto ao mercado de capitais: "Embora venha ganhando fôlego nos últimos 2 anos, contabilizando a emissão primária de recebíveis imobiliários em montante de $R \$ 2,1$ bilhões em 2005 e R\$ 1,1 bilhão em 2006, esses volumes têm correspondido, basicamente, a títulos de financiamentos de edificações comerciais. Até o momento o SFI não avançou muito no crédito habitacional, com inexpressiva injeção de recursos nessa área. A utilização dos recursos do SBPE e FGTS - principais fontes de funding para o financiamento habitacional - precisa também ser avaliada pelo fato de não promover, ao menos em um primeiro momento, acréscimo de recursos ao sistema - lógica que permeia a defesa do mercado secundário. Pelo contrário, os recursos alocados na aquisição de títulos concorrem com as aplicações em novos financiamentos. Para efeito do Planhab nesta etapa do projeto, não estimaremos os possíveis recursos adicionais a serem aplicados por este mercado na área habitacional" (PLANHAB, 2008, item 2.6, p.84). 
CAPÍTULO 4 Tensões e Contradições do Sistema Financeiro Imobiliário 


\subsection{A matriz ideológica do Sistema Financeiro Imobiliário - SFI}

Como todo marco regulatório, o Sistema Financeiro Imobiliário - SFI é um arranjo institucional complexo, unificado por princípios que buscam lhe emprestar coerência e sentido. Assim, falar em SFI é falar, de um lado, de uma nova arquitetura do financiamento imobiliário, composta por um emaranhado de leis, decretos, portarias, instruções normativas e resoluções. Mas falar em SFI é falar também da dinâmica dos agentes regulados, dos riscos envolvidos nas operações, da estruturação de novos mercados e, sobretudo, da natureza de suas metas e dos resultados alcançados.

Neste sentido, o SFI veicula valores que dão inteligibilidade à arquitetura do financiamento imobiliário, tendo como referência a eficiência na distribuição dos riscos entre os agentes envolvidos nas operações e a eficiência na alocação dos recursos financeiros destinados ao setor imobiliário. O protagonismo do mercado nas operações de financiamento, a criação de novos instrumentos de crédito, como o Certificado de Recebíveis Imobiliários (CRI), e de novas formas de garantia, como a alienação fiduciária de coisa imóvel, criaram um ambiente de negócios supostamente mais seguro e mais propício à acumulação de capital e ao financiamento imobiliário em geral.

Neste contexto, não foram poucos os que passaram a defender o uso dos recursos do SFH no ambiente de negócios do SFI'. Para estes, os recursos do SFH poderiam ser um importante instrumento de fomento ao desenvolvimento de um mercado imobiliário moderno, organizado institucionalmente por diretrizes seguras e por uma arquitetura de financiamento baseada no livre acesso ao mercado de capitais. O SFI forneceria o arranjo institucional capaz de estruturar de fato um mercado imobiliário no Brasil, livre das amarras do setor público e do direcionamento do crédito por critérios de natureza política. Os recursos do SFH, neste sentido, poderiam ser

1 Por exemplo, o estudo da Fundação Getúlio Vargas intitulado "O Crédito Imobiliário no Brasil: Caracterização e Desafios", de 2007. Dentre as propostas para a expansão do crédito imobiliário no Brasil, o texto defende medidas de estímulo às operações dos mercados hipotecários e a securitização de recebíveis, assegurando que "a criação do SFI, em 1997, foi um marco institucional. Os instrumentos disponíveis no sistema, no entanto, ainda devem ser testados por uma intensificação das operações. [...] A ampliação das atividades pode acontecer pelo aumento das operações até mesmo com créditos emitidos originalmente no âmbito do SFH" (FGV-Projetos, 2007, p. 45). 
uma espécie de mola propulsora do SFI, que organizaria o financiamento imobiliário em geral, incluindo o financiamento habitacional.

De acordo com estudo realizado pela Fundação Getúlio Vargas, além das iniciativas para a desregulamentação e flexibilização do mercado, o processo de ampliação do crédito passava por

iniciar um amplo debate sobre a elaboração de um modelo de transição que venha a eliminar as restrições sobre o livre funcionamento do mercado, sem, no entanto, deixar desatendidos os diversos segmentos que o compõem. Esse debate deve contemplar medidas que encaminhem o atual sistema na direção de um modelo de financiamento habitacional que funcione de forma mais integrada com o sistema financeiro como um todo, com menores restrições quanto à alocação de crédito. Para tanto, cabe refletir sobre as formas alternativas para o cumprimento das exigibilidades de aplicação durante a vigência de um modelo de transição e rediscutir as atividades de securitização de títulos imobiliários e os critérios de cumprimento de exigibilidades na aplicação dos recursos das cadernetas de poupança (FGV-Projetos, 2007, p.45).

Como examinado no capítulo I, o financiamento habitacional tem sido pretexto para o fomento do crédito imobiliário em geral, propiciando condições para uma captura do sistema de crédito teoricamente direcionado para habitação de interesse social pelos grupos de maior poder aquisitivo, como é exemplo o modelo norte-americano de crédito imobiliário. A propalada superioridade do SFI em relação à operacionalização e capacidade de captação de recursos e a confusão entre os objetos de financiamento do SFI e do SFH vão, aos poucos, rompendo a barreira distintiva entre um modelo estruturado pelo crédito dirigido e pela alocação política dos recursos no sistema e um modelo supostamente estruturado pela livre captação de recursos no mercado financeiro. E, assim como já ocorrera com o SFH nos tempos do BNH, tal confusão permite que os recursos do SBPE e do FGTS sejam canalizado para o financiamento de unidades de maior valor, por famílias de maior poder aquisitivo, em um processo concentrador de renda e de riqueza.

O SFI, por suas características intrínsecas, é incapaz de operar um efeito redistributivo. Em outras palavras, o SFI, sem o apoio do crédito dirigido e da concessão de recursos por parte do Poder Público por meio da alocação das poupanças do FGTS 
e do SBPE, não se mostra capaz de combater o déficit habitacional, especialmente por conta da necessidade de responder aos investidores em primeiro lugar e não à demanda por moradia das famílias de menor renda. A qualificação do SFI como sistema apto a financiar a política habitacional é, neste sentido, um processo ideológico que visa, justamente, a operação do seu contrário - a captura do sistema de crédito subvencionado e a concentração dos recursos do sistema em detrimento dos grupos de menos poder aquisitivo.

A confusão entre o SFH e o SFI expõe, neste sentido, uma contradição da própria matriz teórica do SFI quando aplicada em um país periférico, extremamente desigual, onde o desafio das políticas econômicas sempre foi mais a criação de condições para a existência dos mercados do que a correção de falhas de um mercado imperfeito. Ora, se por estes lados o fundo público sempre foi condição indispensável para a formação dos mercados, se a acumulação de capital sempre teve a atividade estatal como alavanca, como apostar no protagonismo do mercado para a solução do déficit habitacional? Como recorrer à racionalidade econômica das instituições como antídoto à ineficiência da política? Como acreditar na universalização do direito à moradia a partir da criação de um ambiente de negócios seguro e favorável à acumulação de capital? Como compatibilizar o atendimento a uma demanda incapaz de arcar com os custos de aquisição de uma unidade habitacional nas condições de mercado com a necessidade de proporcionar aos investidores do setor imobiliário uma remuneração não inferior à taxa de lucro média do mercado financeiro?

\subsection{A matriz teórica do Sistema Financeiro Imobiliário - SFI}

Compreender os limites e as possibilidades de um arranjo institucional complexo como o SFl exige investigar a matriz teórica que fundamenta suas origens e consolida os princípios que Ihe garantiriam coesão. Indubitavelmente, a matriz teórica que funda o SFI tem origem nos pressupostos da chamada nova economia institucional, elaborada, principalmente, a partir das obras de Ronald Coase, Douglass North e 
Conforme explicação de Medeiros,

o programa teórico da assim chamada nova economia institucional (NEI) objetiva cons-truir uma teoria sobre a formação e evolução das instituições que seja incorporável e compatível com a economia neoclássica, cujas propriedades e hipóteses são consideradas um caso particular. [...] A fundamentação teórica das instituições baseia-se na existência de custos de transação que, por sua vez, existem porque as informações possuem custo e são assimetricamente apropriadas pelos atores participantes da troca. Nesta concepção, as instituições - o conjunto de regras formais (como leis e regulamentos), os constrangimentos informais (como convenções, códigos de conduta) bem como mecanismos de promoção e coerção das leis - são formadas para reduzir as incertezas nas interações humanas (Medeiros, 2001, p. 50-51).

O coração da nova economia institucional é o conceito de custo de transação, isto é, a percepção de que em qualquer negócio há custos incorporados pelos agentes relativos à própria negociação. Como conseqüência, as instituições são relevantes aos agentes econômicos porque são elas que moldam a estrutura de incentivos de uma economia, reduzem os custos das transações e propiciam a geração de eficiência. O SFI, dentro desta concepção teórica e, enquanto instituição, deveria incidir sobre os custos de transação do mercado imobiliário, isto é, deveria organizar um ambiente de negócios seguro ao investimento privado, que mitigasse as chamadas falhas de mercado ${ }^{2}$ e reduzisse substancialmente a ineficiência econômica dos negócios imobiliários.

A filiação do Sistema Financeiro Imobiliário à nova economia institucional pode ser comprovada nas manifestações da equipe econômica do governo justificando a sua criação ${ }^{3}$, nas análises técnicas das entidades de classe que sempre apoiaram a me-

2 De acordo com NUSDEO, "as falhas de mercado correspondem a situações nas quais os seus pressupostos de funcionamento não se fazem presentes, tornando-o inoperacional". São exemplos de falhas de mercado: os efeitos externos (falha de sinal), a concentração econômica (falha estrutural), a assimetria de informações (falha legal), a imobilidade de fatores (falha de origem física ou cultural) e a deficiência no suprimento de bens coletivos (falha de incentivo). NUSDEO, Fábio. Curso de Economia - Introdução ao Direito Econômico. São Paulo: Editora Revista dos Tribunais, 2005, p. 169.

3 Nota técnica do BACEN relativa à Resolução CMN n. 3.005 e Exposição de Motivos da Lei n. $9.514 / 1997$ 
dida ${ }^{4}$, nos textos acadêmicos ${ }^{5}$ e, principalmente, nos documentos do Banco Mundial ${ }^{6}$, todos partindo do pressuposto de que o problema do mercado imobiliário no Brasil é um problema institucional, isto é, da ausência de instituições capazes de garantir a lucratividade e a sugurança dos investimentos alocados no setor.

De acordo com o texto da Fundação Getúlio Vargas, já referenciado, a sustentabilidade do sistema de financiamento imobiliário depende dos seguintes aspectos:

- aperfeiçoamento do ambiente institucional, com destaque para o respeito aos contratos e prevalência das regras de mercado;

- fortalecimento do arcabouço regulatório;

- gradativa redução das restrições à alocação de crédito (repressão financeira);

- rápida desburocratização das operações de concessão de crédito;

- redução de custos e impostos incidentes sobre as operações.

Assim, a par dos trabalhos laudatórios ao novo sistema, as análises sobre o SFI partem quase sempre da mesma constatação - a necessidade de estabelecer regras do jogo favoráveis ao desenvolvimento do mercado imobiliário, ao estímulo das operações nos mercados hipotecários, ao fortalecimento da regulação e da proteção dos contratos e da propriedade. Em síntese, a necessidade de dotar as instituições de uma racionalidade típica da economia de mercado, criando um ambiente de negócios seguro ao investimento privado.

Ainda de acordo com Medeiros, a nova economia institucional parte do argumento

4 Os editoriais da Revista do SFI, editada pela ABECIP, reforçam esse argumento. Ver, como exemplo, Revista do SFI, ano 8, n017, 2004.

5 Ver, como exemplo, BROLLO, Fernanda. Crédito Imobiliário e Déficit de Moradias: Uma Investigação dos Fatores Econômicos e Institucionais do Desenvolvimento Habitacional no Chile e no Brasil. São Paulo, 2004. Dissertação (Mestrado) - Escola de Economia de São Paulo, Fundação Getúlio Vargas. CARNEIRO, Dionísio D.; GOLDFAJN, Ilan. A Securitização de Hipotecas no Brasil. Texto para discussão n426. Rio de Janeiro: Departamento de Economia da PUC, jun/2000. CARNEIRO, Dionísio D.;VALPASSOS, Marcus V.F. Financiamento à habitação e instabilidade econômica: experiências passadas, desafios e propostas para a ação futura. Rio de Janeiro: Editora FGV, 2003. FGV. O Crédito Imobiliário no Brasil - Caracterização e Desafios. São Paulo: FGV-Projetos, 2007. LIMA JR. Recursos para Empreendimentos Imobiliários no Brasil - Debêntures e Fundos. Boletim Técnico do Departamento de Engenharia de Construção Civil - Escola Politécnica da Universidade de São Paulo BT - 28/90. São Paulo: EPUSP, 1990.

6 WORLD BANK. Building Institutions for Markets. Nova lorque: Oxford University Press, 2002. Os cursos promovidos pela instituição destinados a mercados emergentes também estão eivados da concepção do BM quanto ao papel do estado e das instituições no fomento ao mercado. 
de que o "subdesenvolvimento decorre da existência de instituições que inibem as relações econômicas; estas instituições persistem porque obedecem a uma racionalidade política de grupos não competitivos encastelados no Estado" (Medeiros, 2001, p. 53).

E mais, constata que

a evolução das relações mercantis demanda instituições que, através da diminuição dos riscos e da proteção dos contratos privados, impulsionem estas relações num movimento cumulativo e favorável ao desenvolvimento econômico. As inovações institucionais orientadas segundo as necessidades de proteção, garantias e informação dos mercados constituem, a seu ver, o processo essencial do desenvolvimento econômico. Por oposição, o não-desenvolvimento é o resultado também de uma causação circular e cumulativa em que as instituições tolhem o funcionamento dos mercados instabilizando os contratos, atropelando os direitos de propriedade e criando outros, inibidores das trocas (Medeiros, 2001, p. 54).

Nesta linha, para induzir o desenvolvimento, é fundamental promover instituições eficientes, dinâmicas e subordinadas à racionalidade dos mercados. Ao mesmo tempo, é fundamental restringir as iniciativas apoiadas em racionalidades não-econômicas, principalmente as estruturadas a partir da política e das decisões governamentais.

Os adeptos da nova economia institucional, a partir deste diagnóstico "anti-cepalino"7 sobre as causas do subdesenvolvimento, fundamentam teoricamente uma ampla agenda de reformas na América Latina. A reforma do Sistema Financeiro de Habitação - SFH e a promoção do novo Sistema de Financiamento Imobiliário - SFI devem ser compreendidas neste contexto. Não se trata simplesmente de novas disposições normativas sobre o financiamento da habitação e do crédito imobiliário no Brasil. Trata-se, na verdade, da tentativa de substituir um modelo de financiamento baseado na intensiva participação estatal para um modelo de financiamento "market-oriented", que busca elevar o mercado à condição de protagonista do sistema. A diminuição do controle estatal sobre o crédito dirigido, o fortalecimento do mercado de capitais como fonte privilegiada de financiamento, a introdução de novos

7 Sobre a oposição entre os marcos teóricos da nova economia institucional e a teoria cepalina do desenvolvimento ver MACEDO, Bernardo Gouthier. Desenvolvimento Econômico: a atualidade da economia política cepalina. 2007. Tese (Doutorado). Instituto de Economia, Universidade Estadual de Campinas. Campinas, 2007. 
instrumentos de captação de recursos, além da certeza da inviolabilidade da propriedade e dos contratos, constituem, no campo imobiliário, o passaporte para mais uma rodada do processo de modernização do capitalismo periférico.

O processo de imitação do centro do sistema, típico da modernização na periferia, atingiu desta forma o âmbito das instituições. O Consenso de Washington, de modo particular, foi uma grande reverberação dos arranjos normativos do núcleo orgânico do capitalismo na América Latina. Mais de uma década depois, já é possível avaliar os resultados desta empreitada, separando os resultados concretos das políticas liberalizantes dos discursos neoliberais mais inflamados. Em relação ao SFI, é preciso avaliar os seus resultados tendo em vista os parâmetros políticos inscritos na Constituição, em especial, o dever do Estado garantir o acesso à moradia como direito fundamental. Além disso, é fundamental identificar os avanços e os recuos na implementação deste modelo de financiamento, buscando compreender as razões de cada um destes movimentos. Por fim, não é possível ignorar como o SFI propicia a alteração da apropriação do excedente pelos agentes envolvidos no sistema, mudando a correlação das forças que disputam os recursos disponíveis para o financiamento imobiliário no Brasil.

\subsection{O SFI e a agenda neoinstitucional}

Em 2002, o Banco Mundial publicou um relatório cujo título não poderia ser mais revelador - "Construindo Instituições para o Mercado"8. De acordo com o texto, é incontestável que os mercados são centrais na vida da população mais pobre, que afetam positivamente o padrão de vida das pessoas e que ajudam a proteger os seus direitos. Portanto, na esteira das políticas do Banco da década anterior, era fundamental promover instituições que impulsionassem o crescimento econômico e reduzissem a pobreza, tendo como premissa o protagonismo do mercado na condução do desenvolvimento econômico. 
Para construir instituições eficientes, isto é, instituições subordinadas à racionalidade do mercado, era preciso seguir quatro orientações: complementar as instituições já existentes, incorporando recursos humanos e tecnologias disponíveis; inovar na criação de instituições mais fortes, expandindo as experiências públicas bem sucedidas e adotando as inovações do setor privado; conectar todos os agentes econômicos por meio da liberdade de empresa e, por fim, promover a concorrência como condição de bom funcionamento das instituições (World Bank, 2002, parte IV). Em síntese, o núcleo do processo de desenvolvimento preconizado pelo Banco Mundial passava pela disseminação de economias de mercado, pela disseminação de instituições "market oriented".

De acordo com o Banco Mundial, instituições são

as regras, os mecanismos de coerção e as organizações [que] sustentam as transações no mercado. [...] Diferentemente das políticas, que são constituídas por metas e resultados desejados, as instituições são as regras, inclusive comportamentais, por meio das quais os agentes interagem. [...] [Basicamente,] as instituições têm três propósitos: canalizar informação sobre as condições de mercado, mercadorias e agentes; [...] definir e reforçar os direitos de propriedade e os contratos, determinando quem ganha o que e quando; [...] e aumentar ou diminuir a competitividade $^{9}$ (World Bank, 2002, p. 6; 8).

Construir instituições para o mercado, nestes termos, é construir arranjos normativos e organizacionais voltados à livre circulação de mercadorias, que permitam a realização destas três vocações. É por isso que, de acordo com o relatório, os governos nacionais devem responder às pressões do setor privado e dos agentes externos e dar impulso às reformas, sempre que demandado. Não haveria outra forma possível de desenvolvimento que não a orientada pelos mercados.

No caso do setor imobiliário, em pleno auge do neoliberalismo na América Latina, construir instituições para o mercado significava reorientar as instituições existentes

9 Rules, enforcement mechanisms and organizations [...] that support markets transactions. Distinct from policies, which are the goals and desired outcomes, institutions are the rules, including behavioral norms, by which agents interact [...] Institutions do three main things: they channel information about market conditions, goods, and participants. [...] they define and enforce property rights and contracts, determining who gets what and when. [...] They increase competition in markets - or decrease it. 
e constituir novos arranjos que permitissem o protagonismo do setor privado na articulação do setor, realizando aquelas três funções essenciais - canalizar as informações sobre as condições de mercado, mercadorias e agentes do setor; definir e reforçar os direitos de propriedade e os contratos; e, por fim, aumentar a competitividade entre os vários agentes envolvidos. O SFI, em grande medida, traduz normativamente os objetivos desta agenda do Banco Mundial. A história da sua implantação, no mesmo sentido, reflete os avanços e os recuos da agenda institucionalista na remodelagem do setor imobiliário no Brasil.

Na perspectiva do Banco Mundial, a construção dos novos arranjos financeiros do sistema deveria começar por uma nova fonte de captação de recursos. Por este motivo, prescrevia aos países emergentes a estruturação do mercado de capitais como o locus privilegiado da captação de recursos para o financiamento imobiliário, aliando a eficiência das bolsas de valores com a liquidez dos mercados financeiros, principalmente dos grandes investidores institucionais, como os fundos de pensão. O processo de globalização, que conectara os mercados financeiros em tempo real, seria a grande mola de impulsão do setor imobiliário.

Neste contexto, vários instrumentos financeiros foram desenvolvidos, notadamente os voltados à captação de recursos para o setor imobiliário. Como exemplo, podemos mencionar a criação do mercado secundário de hipotecas e o processo de securitização de grandes ativos, que possibilitava uma melhor distribuição dos riscos e a captação de recursos alavancados. Segundo o Banco Mundial, a redução do risco implicava a redução dos juros, em uma relação direta, o que permitia aumentar a liquidez e, conseqüentemente, a captação de novos recursos. Essa seria, então, a principal razão para se promover o desenvolvimeento dos mercados secundários e da securitização de hipotecas: a minimização do custo do financiamento pela redução dos juros da operação (Chiquier; Hassler; Lea, 2004).

No entanto, nos países emergentes, uma série de barreiras institucionais dificultava a introdução destes novos arranjos financeiros, entre eles o processo de securitização. Como exemplo, podemos citar a ausência de marcos regulatórios estáveis, capazes de oferecer garantias mínimas aos investidores privados, e a pouca atra- 
tividade dos papéis tradicionais para realizar a captação primária dos recursos. Além disso, o mercado de hipotecas sempre foi muito limitado nestes países, com pouca segmentação em função dos riscos e pouca atratividade em face de investimentos mais seguros e com rentabilidade muito maior, como os títulos da dívida pública e os chamados fundos de renda fixa.

De acordo com o Banco Mundial, a construção de um mercado secundário de hipotecas depende da constituição de um mercado de capitais forte e atuante, com produtos financeiros voltados ao financiamento de longo prazo. Além disso, depende da oferta de taxas de retorno atraentes, autorização legal para o investimento de certos fundos em títulos hipotecários, além da própria disposição do investidor em apostar em um mercado de risco como é o mercado de securitização hipotecária. Como não poderia deixar de ser, para que estas condições de oferta e demanda fossem atendidas, era preciso uma intervenção do Estado sobre o domínio econômico capaz de assegurar os investimentos neste mercado. Em outras palavras, nos países emergentes, não bastaria ao Estado regular o mercado a partir da correção das desigualdades sociais. Era fundamental que o Estado estruturasse os mercados, criando regras de investimento, estimulando a demanda dos agentes públicos e privados e, acima de tudo, implementando um ambiente institucional capaz de transmitir confiança aos investidores.

Nesta perspectiva, ainda de acordo com o Banco Mundial, era preciso que os governos garantissem condições para o surgimento dos mercados primários e secundários de hipoteca e que incluíssem o financiamento habitacional no processo de liberalização dos mercados financeiros. Inegavelmente, o governo exerceria, neste caso, um papel fundamental para reduzir a percepção de risco por parte dos investidores. Mas não era só isso. Era preciso que o governo planejasse sua participação para que sua intervenção não ultrapassasse o mínimo necessário ao desenvolvimento das instituições que conformam o mercado, retirando-se tão logo o objetivo fosse alcançado. A intervenção estatal, dizia o Banco, deveria se limitar ao patrocínio de instituições, ao fornecimento de garantias para os títulos emitidos por agentes privados, à promoção da liquidez por meio de compras governamentais e à concessão de incentivos à emissão de títulos hipotecários (especialmente com a desoneração 
tributária).

Estabelecer uma estrutura de mercado adequada, reduzir o risco da securitização de hipotecas por meio de garantias explícitas ou implícitas (vg, detendo participações em fundos hipotecários), desonerar os investimentos de tributos e qualquer tipo de ônus fiscal... Para o Banco Mundial, o governo pode e deve desempenhar o papel de catalisador do processo de formação de novos mercados financeiros, proporcionando a redução de incertezas para os agentes privados. Por isso, apesar da imaturidade do mercado de capitais nos países periféricos, todos os esforços na construção de um modelo de financiamento imobiliário alternativo devem ser considerados, em função dos efeitos positivos que ele teria sobre o conjunto de toda a economia.

De acordo com um grande executivo do Freddie Mac, Federal Home Loan Mortgage Association, é extremamente positivo para os países emergentes apostar na criação de um mercado secundário de hipotecas, uma vez que a existência deste tipo de investimento pode contribuir para que o país amplie seu acesso ao mercado financeiro internacional, em particular o seu acesso a financiamentos de longo prazo, contribuindo para a redução de sua volatilidade e alavancando o próprio mercado primário:

Muitos países não dispõem atualmente de mecanismos efetivos para conectar o mercado de hipotecas com o mercado de capitais. Mercados secundários são uma forma de aproveitar os mercados de capital internacionais, particularmante para empréstimos de longo prazo [...] A habitação é, potencialmente, uma ótima garantia, podendo-se esperar que ela seja um caminho para se obter mais investimentos externos de longo prazo, reduzindo a dependência de hot money, se ela realmente puder ser uma efetiva garantia ${ }^{10}$ (Van Order, 2003, p. 29).

Segundo o mesmo autor, a experiência americana mostra, em linhas gerais, que os pontos fundamentais para integrar o mercado hipotecário ao mercado de capitais são a existência de uma estrutura legal e regulatória que permita a rescisão de contratos, o atrelamento dos imóveis às obrigações financeiras e a possibilidade de

10 Many countries do not currently have effective ways of linking mortgage markets with capital markets. Secondary markets are a way of tapping international capital markets, particularly for long-term loans. [...] Housing is potentially very good collateral and can be expected to be a way of getting more long-term foreign money, decreasing the dependence on hot money, if it really can be effective collateral. 
despejo, além de condições macroeconômicas estáveis, o que pode ser alcançado com poucos subsídios.

Não há em seus argumentos menção ao aumento do acesso à moradia, muito menos à erradicação dos déficits habitacionais dos países emergentes. A questão primordial, quase exclusiva, é a integração do mercado hipotecário ao mercado de capitais, como um fim em si mesmo.

Segundo o Banco Mundial, outro problema institucional que inibe o desenvolvimento dos mercados secundários de hipoteca nos países periféricos é a centralização dos recursos voltados ao financiamento imobiliário em um número reduzido de instituições, o que desestimula a securitização como forma de acesso à liquidez, tornando desnecessário o mercado secundário:

A estrutura dos mercados hipotecários também é um obstáculo em alguns países. Se um mercado é dominado por um pequeno número de instituições de depósito com grande porte e liquidez, será difícil criar um mercado de securitizição hipotecária bem sucedido. Os grandes emprestadores, que podem racionar os fundos hipotecários, não necessitam do financiamento e podem determinar o preço de novos competidores usando linhas de financiamento no varejo fora do mercado. Estes emprestadores também não precisam de títulos hipotecários para administrar riscos de fluxo de caixa, já que seus principais instrumentos hipotecários são ARM que podem conectar fundos com depósitos ${ }^{11}$. (Chiquier; Hassler; Lea, 2004, p. 34-35)

Impossível não relacionar esse tópico com críticas feitas à Caixa Econômica Federal por parte de algumas missões de técnicos ou profissionais ligados ao Banco Mundial ${ }^{12}$. Alguns textos são peremptórios em afirmar que enquanto a Caixa dominar os

11 The structure of mortgage markets is also an obstacle in some countries. If a market is dominated by a few large, liquid depository institutions, it will be difficult to create a successful mortgage securities market. The large lenders, who may ration mortgage funds, do not need the funding and can price new competitors using wholesale funding out of the market. These lenders do not need mortgage securities to manage cash flow risk either as their main mortgage instrument is an ARM that can match fund with deposits.

12 Curso "Subsídios e Financiamentos Habitacionais como Instrumentos de Política de Habitação Popular" Marja Hoek-Smith, Wharton School University of Pensilvania. Banco Mundial/Caixa Econômica Federal, Brasília, agosto/2002. No curso foram discutidas as condições e as agendas que deveriam ser implementadas para fomentar a habitação popular. Um dos principais argumentos, de acordo com a apresentação feita, foi de que o fomento governamental ao mercado de financiamento privado seria fundamental: "Two main reasons for limited access to housing finance: incomplete credit markets and market and policy failure-government housing finance institutions have excessive market power and they are price makers". Ou seja, dentre as duas principais razões para 
financiamentos habitacionais não será possível uma ampliação do acesso ao crédito no país, argumento que, em face dos números recentes dos financiamentos concedidos em todo o sistema financeiro com recursos do FGTS e do SBPE, fica difícil de sustentar.

É inegável o acento privatista das recomendações do Banco Mundial e o total desincentivo para a criação ou fortalecimento de instituições estatais que controlem um segmento de mercado de modo permanente e não apenas até o seu 'fortalecimento'.

Os desenhos institucionais mais bem sucedidos têm sido centrados mais na garantia de liquidez do que em conduits. Pode-se observar que talvez esteja havendo um foco excessivo na criação de instituições antes de outros fundamentos. Apenas criar uma institução relacionada ao mercado secundário não criará um mercado. Os esforços de desenvolvimento em vários países emergentes têm focado no desenvolvimento institucional, particularmente conduits com envolvimento do governo. Em muitos casos, eles podem estar à frente do seu tempo (ou ser soluções à procura de um problema). Governos e consultores técnicos talvez precisem empregar mais tempo e recursos no desenvolvimento de infraestruturas que permitam emissões particulares de papéis e títulos antes de se investir em instituições ${ }^{13}$ (Chiquier; Hassler; Lea, 2004, p.35-36).

Ou seja, o principal papel do Estado é a garantia de liquidez no desenvolvimento dos mercados secundários. Para lembrar uma clássica classificação de importante autor no campo do direito, o Estado pode intervir no domínio econômico, desenvolvendo ações como agente econômico, ou sobre o domínio econômico, desenvolvendo ações como regulador das atividades econômicas (Grau, 2008, p. 174-175). No caso

\footnotetext{
o limitado acesso ao financiamento habitacional estaria o excessivo poder de mercado que tem as instituições governamentais de financiamento habitacional, afinal elas seriam formadoras de preço e não deixariam que o mercado se autoregulasse. Nos debates ocorridos ao final do curso, representantes do Banco Mundial disseram que pelo desenho do mercado brasileiro, 'onde houver CEF não virão bancos privados' afinal, os subsídios para essas instituições reduzem o interesse do mercado para o empréstimo a renda média e baixa (subsidies to state housing finance institutions reduce private lenders interest in low-moderate income lending).

13 The more successful institution designs have been liquidity facilities rather than conduits [...]. It can be observed that there may be an excessive focus on institutional creation in advance of other fundamentals. Simply creating a secondary market institution will not create a market [...]. Development efforts in many emerging countries have focused on institution development, particularly conduits with government involvement. In many cases they may be ahead of their time (or solutions in search of a problem). Governments and technical assistance providers may need to spend more time and resources spent in infrastructure development to allow individual issues of mortgage bonds and securities before investing in institutions.
} 
do financiamento imobiliário, é muito clara a defesa pelo Banco Mundial de uma intervenção exclusivamente sobre o mercado de crédito, garantindo as condições de oferta e demanda. É muito claro também o desincentivo à intervenção do Estado no domínio econômico por meio de instituições bancária estatais.

Além do Banco Mundial, outros atores vêm propondo a adoção de agendas institucionais para a expansão do crédito imobiliário no Brasil. Exemplo disso é o documento já referido, publicado pela Fundação Getúlio Vargas, expondo algumas diretrizes para "dinamizar o mercado financeiro, e com isso, o crédito como propulsor do desenvolvimento, e estabelecer uma política social de habitação continuada, que possa aos poucos zerar nosso déficit habitacional" (FGV-Projetos, 2007, p.3).

Basicamente, o documento da Fundação Getúlio Vargas apresenta quatro grupos de propostas, tendo em vista o desafio de expansão do crédito imobiliário no Brasil (FGV-Projetos, 2007, p.43-45).

(i) Medidas voltadas à habitação social: subsídios às famílias de renda mais baixa para aquisição da casa própria, concessão direta de recursos por parte do Poder Público nas três esferas de governo e direcionamento de certa parte dos recursos do SBPE, em condições especiais;

(ii) Medidas fiscais: iniciativas de desoneração tributária como estímulo adicional à constituição de capital habitacional no país. O estímulo fiscal poderia ser direto, incidindo sobre os custos do crédito imobiliário, ou indireto, incidindo sobre os custos da construção civil.

(iii) Medidas referentes ao mercado de crédito imobiliário: ampliação das formas de captação de recursos, com a entrada de novos agentes no mercado, com a desregulação gradativa do mercado e com a flexibilização das regras de direcionamento de crédito. Além disso, "deve-se procurar reduzir o custo da intermediação financeira e também minimizar as imperfeições nos mercados. [...] reduzir o grau de rigidez sobre os juros [...] aumentar o grau de certeza das transações de crédito [...] dar maior flexibilidade para captação de recursos para o sistema [...] desburocratizar a originação dos contratos [...] modelo de transição que venha 
a eliminar as restrições sobre o livre funcionamento do mercado [...] modelo de financiamento habitacional que funcione de forma mais integrada com o sistema financeiro como um todo, com menores restrições quanto à alocação de crédito." Afinal, "o bom funcionamento do mercado de crédito imobiliário [...] pressupõe também uma queda dos custos regulatórios e uma eliminação das falhas de mercado, pela ação pontual das políticas públicas" (FGV-Projetos, 2007, p.41).

(iv) Medidas de estímulo às operações nos mercados hipotecários - securitização: dado o potencial de desenvolvimento dos mercados hipotecários, é possível atrair capitais de diferentes origens, além de investidores que tradicionalmente não atuam em operações imobiliárias. Além disso, é fundamental a ampliação deste mercado para novos participantes, como fundos de pensão, seguradoras e companhias hipotecárias.

Conclui ainda o estudo que o modelo de financiamento deve se apoiar em dois pilares - o atendimento das carências habitacionais da população menos favorecida e a expansão das atividades de mercado, ampliando as fontes e modalidades de crédito de longo prazo. (FGV-Projetos, 2007, p.46).

Mais uma vez, assim como propõe o Banco Mundial, o atendimento dos mais pobres aparece na agenda política, ao lado da expansão da economia de mercado como o centro da política de crédito. Resta saber até que ponto é possível aproximar estes pontos como política social efetiva e não apenas como retórica justificadora da apropriação dos recursos pelos grupos de maior poder aquisitivo.

Essa introdução da agenda do Banco Mundial no Brasil por meio do SFI não foi feita sem estudos e análises por parte do governo e das entidades ligadas ao crédito imobiliário. De acordo com a ABECIP:

em 1995, foi iniciado um intenso trabalho de análise dos sistemas mundiais, com a finalidade de se buscar a melhor alternativa para ser adaptada à realidade brasileira. Dentre os trabalhos desenvolvidos, merece ser destacada a comitiva formada por representantes do sistema financeiro privado e público, do Banco Central, do Ministério da Fazenda e de vários empresários que, em março de 1995, foi aos Estados Unidos para conhecer o mode-lo de financiamento imobiliário americano, 
centrado na securitização. [...] Foram ainda realizados, no mesmo ano, vários encontros. O principal deles foi o VII Encontro Nacional, também promovido pela ABECIP, em novembro de 1995. Nesse evento, foram apresentadas as premissas de um novo modelo de crédito imobiliário, que resultou na Lei 9.514 de 1997 [...] modelo que estudos revelaram como o mais apropriado para o Brasil, por não ter nenhuma dependência de funding direto ou de direcionamento obrigatório (ABECIP, 2005, p. 26).

É curioso notar que essa tão decantada independência de funding ou de direcionamento de recursos não significou, em nenhum momento, um repúdio aos recursos que tradicionalmente compuseram o funding da política habitacional brasileira. Assim, ao mesmo tempo em que alguns agentes proclamam a necessidade de uma agenda institucional voltada a um novo modelo de crédito imobiliário, mantém-se a defesa dos recursos da poupança como a base da arquitetura de financiamento. Nesta perspectiva, os recursos do SBPE e do FGTS seguem como os fundos mais importantes para sustentar a produção de novas unidades, não necessariamente por meio do financiamento direto a construtoras ou a empreendimentos, mas também - e talvez, segundo o modelo do SFI, prioritariamente - por meio da aquisição de títulos com lastro imobiliário.

Como reconhece o estudo da Fundação Getúlio Vargas, o mercado de crédito imobiliário está interessado na entrada de novos agentes no mercado de crédito, tais como as seguradoras e os fundos de pensão. Por isso é necessário flexibilizar o direcionamento do crédito imobiliário, de modo que os 'recursos baratos' da poupança, e mesmo do FGTS, possam viabilizar o mercado secundário de títulos imobiliários.

Em relação ao desenvolvimento do mercado secundário, o apoio do Banco Mundial e de outras agências de fomento não foi apenas por meio de seu capacity building junto aos go-vernos locais e federal. Desde o início de suas operações, empresas que operam nesse mercado receberam recursos diretamente do próprio BID, como atesta uma entrevista de Fábio Nogueira, diretor executivo da Brazilian Finance \& Real Estate, holding que agrupa a Brazilian Securities, Brazilian Capital, Brazilian Mortgages e BM Sua Casa, braço de varejo: "Desde o início a Brazilian Securities conta com o apoio do Banco Interamericano de Desenvolvimento (BID). Hoje a empresa tem uma 
A CIBRASEC, Companhia Brasileira de Securitização também conta com o apoio do Banco Mundial: "A Cibrasec - primeira companhia de securitização do Brasil - oferece CRIs com taxas de rentabilidade atrativas [...] Há uma razão a mais para atrair os investidores para os CRIs, pois, a partir de 28 de setembro de 2004, a Cibrasec passou a ter como associada a International Finance Corporation (IFC), subsidiária do Banco Mundial, cuja participação será de 9,09\% no capital da Cibrasec"115.

A dinâmica dos investimentos em CRI e a quantidade de recursos envolvidos nesse mercado são retratadas na mesma entrevista de Fábio Nogueira citada acima:

A (Brazilian) Capital é o nosso, digamos, banco de investimentos. Ela cuida dos investidores locais e internacionais sempre com enfoque de otimizar o investimento deles no mercado imobiliário. Nosso objetivo todo é instrumentos financeiros de liquidez. Aqui quando se fala em fundo imobiliário, se fala em uma gestão passiva, gestão fiduciária. Então, se a pessoa comprou uma cota do shopping Higienópolis, que foi o primeiro que a gente fez, fica com aquilo estanque. A Brazilian Capital faz a gestão ativa - compra, vende. É o único caso dos fundos de varejo. A gente é muito fiduciário. Então, evita conflito. Aqui tem incorporação, investimento em imóveis. A gente atende os clientes da Hedging Griffo, estrangeiros - tem até um fundo de pensões canadense, que é dono das lojas C\&A no Brasil - e fundo de CRIs. O legal da (Brazilian) Capital é que não tem no Brasil uma empresa que atue como ela. Há gestores de investidores estrangeiros. A Tyshman Speyer Properties, por exemplo, é isso, então, só investe em produtos Tyshman. Nós temos vários fundos, são oito fundos. Hoje ela administra R\$2,3 bilhões em ativos imobiliários ${ }^{16}$.

A captação de novos recursos propugnada pelos modelos institucionais "market oriented" tem ocorrido, prioritariamente, por meio desse tipo de fundo.

Os operadores do mercado sustentam que os recursos captados pelos fundos junto ao mercado de capitais não deveriam ser alocados na produção de empreendimentos (ver capítulo 3), e sim no financiamento de longo prazo: "a captação de recursos de curto prazo para a concessão de empréstimos de duração mais longa é um fator de

$14 \quad$ FLACH, Natalia. Governo precisa incentivar securitização. Jornal Gazeta Mercantil, 09 abr 2009 , p. 2.

15 Anúncio publicitário veiculado na contracapa da Revista do SFI Ano 8, n¹8, 2004.

$16 \quad$ FLACH, Natalia. Op. cit. 
instabilidade. Além disso, o modelo fundado na segmentação do mercado de crédito tende a ter sua capacidade de financiamento restrita ao tamanho desse funding que é a poupança" (FGV-Projetos, 2007, p.11).

O SFI, sob esse ponto de vista, seria, então, o ambiente ideal para a comercialização do imóvel, e não tanto para a produção. O spread entre a baixa taxa de juros que remuneraria a captação de recursos destinados à construção - obtidos via poupança, por exemplo - e a taxa de juros cobrada do tomador do financiamento de um imóvel com recursos captados no mercado de capitais, por exemplo, seria suportado, neste caso, pelo próprio tomador. E para investidores do nível da reportagem citada acima, tal spread não seria meramente simbólico, mas sim uma remuneração bastante atrativa. Se esse desenho for aplicado a um imóvel habitacional, essa taxa de juros do financiamento tende a deixar de fora mesmo boa parte da demanda solvável, afinal, trata-se de mercado, de negócio, e não da efetivação de direito social.

Tal modelo não nos parece sustentável quando analisamos a realidade das necessidades habitacionais do país. Na construção imobiliária, especialmente de empreendimentos comerciais, escritórios e outros, é possível que o modelo preconizado seja de fato uma saída para a captação de recursos. No entanto, para o mercado habitacional, especialmente para as faixas de renda nas quais o déficit é muito alto, não há estudo que demonstre efetivamente como esta conta fecha. O próprio estudo da Fundação Getúlio Vargas reconhece que "em seus nove anos de existência, o maior êxito do SFl está associado ao financiamento de edificações comerciais. Na área habitacional, o sistema não logrou expressivos avanços" (FGV-Projetos, 2007, p.10). 


\subsection{Características da urbanização brasileira e o déficit habitacional}

A urbanização brasileira, marcada por profundas desigualdades, é um fenômeno relativamente recente, que teve seu impulso principal a partir dos anos 40 do século XX. Entretanto, foi só na década de 70, em pleno "milagre brasileiro", que as cidades e metrópoles assumiram a feição que vemos hoje. De acordo com Maricato, "o processo de urbanização, acelerado e concentrado, marcado pelo 'desenvolvimento moderno do atraso,', cobrou, a partir dos anos 80, após poucas décadas de intenso crescimento econômico do país, um alto preço, mediante a predação ao meio ambiente, baixa qualidade de vida, gigantesca miséria social e seu corolário, a violência" (Maricato, 1996, p. 31). O trecho citado salienta o caráter da miséria social e da violência que marca nossa urbanização. A industrialização com baixos salários, independente da formalidade das relações de trabalho e emprego, gerou como "subproduto" as cidades ilegais e precárias que vivemos.

Os números absolutos do processo de urbanização nos auxiliam a compreender sua dimensão: em 1940, o Brasil tinha 18,8 milhões de habitantes residindo em cidades, enquanto que em 2000 esse número era de 138 milhões. Em um curto espaço de tempo para o desenvolvimento de uma cidade, a população cresceu mais de sete vezes, sem que esse crescimento fosse acompanhado da infra-estrutura e dos serviços que fazem da cidade o signo da superação do arcaico e do atraso nas sociedades ocidentais. Ao invés de vir acompanhado dos ares livres da cidade, " $a$ urbanização recria o atraso através de novas formas, como contraponto à dinâmica de modernização" (Maricato, 2001, p. 15).

Em período semelhante, de 1940 a 1980, registra-se um crescimento médio do Produto Interno Bruto do país de 7\% ao ano, índice que denota um aumento de riqueza de grandes proporções, um dos maiores crescimentos comparados do PIB mundial no período.

Considerando estas duas informações apenas, o aumento da população urbana no país e do PIB, no período de 1940 a 1980, poderíamos chegar à conclusão de que o Brasil ingressaria no século XXI como um país rico, moderno e urbanizado, além de 
deter recursos naturais privilegiados. O retrato, porém, do que se vê e se vive no país está distante dessa suposição, ainda que algumas dessas características ajudem a montá-lo fidedignamente.

A distribuição de renda no Brasil auxilia-nos a compreender o que a industrialização com baixos salários significou. Em 1960, segundo o censo demográfico, os 20\% mais pobres detinham 3,5\% da renda nacional, enquanto que os 10\% mais ricos, detinham 39,7\% dessa renda. Em 1990, essa relação mudou para 2,3\% da renda para os 20\% mais pobres e 49,7\% para os 10\% mais ricos (IPEA, 1993).

Nota-se, assim, que a despeito dos números do PIB no período, sua distribuição não logrou elevar o país a uma categoria de distribuição de riquezas compatível com os países desenvolvidos. A entrada do Brasil na industrialização, proporcionando um inegável crescimento de sua riqueza interna, deu-se em uma base já profundamente desigual da sociedade, e o que o processo de modernização fez foi, na verdade, aprofundar essa desigualdade, fato espelhado nas cidades brasileiras: "como parte integrante das características que assume o processo de acumulação capitalista no Brasil, o urbano se institui como pólo moderno ao mesmo tempo em que é objeto e sujeito da reprodução ou criação de novas formas arcaicas no seu interior, como contrapartidas de uma mesma dinâmica" (Maricato, 2001, p. 15).

Moradias improvisadas embaixo de pontes e viadutos, ocupação de morros, várzeas, mangues, igarapés, encostas, fundos de vale, beira de córregos, rios e represas, poluição de recursos hídricos, poluição do ar, impermeabilização da superfície do solo, desmatamento de áreas, enchentes, desmoronamentos, incêndios em edificações deterioradas, alta densidade habitacional, doenças de veiculação hídrica, doenças respiratórias, violência urbana, compõem o que Maricato classifica como a "tragédia urbana brasileira".

Mesmo quando é criada uma política que busca a solução do problema habitacional evitando seu agravamento, esse desenvolvimento moderno do atraso mostra sua face: "A análise do SFH e o BNH fornece um exemplo muito adequado da modernização excludente [...] essa política foi fundamental para a estruturação de um mercado imobiliário de corte capitalista. [...] Combinando investimento público com ação reguladora, o 
Estado garante a estruturação de um mercado imobiliário capitalista para uma parcela restrita da população, ao passo que para a maioria restam as opções das favelas, dos cortiços ou do loteamento ilegal, na periferia sem urbanização, de todas as metrópoles" (Maricato, 2001, p. 46).

Neste cenário, o conceito de déficit habitacional ainda é extremamente relevante. É difícil imaginar um critério de mais fácil compreensão para medir resultados de uma política ha-bitacional que a oscilação do déficit de moradias. Porém, assim como a habitação virou ideologia a serviço da captura do sistema de crédito, o déficit habitacional tem servido como peça retórica deste processo de mistificação.

Há muitas críticas ao conceito de déficit habitacional. A principal delas é a simplificação que o conceito econômico de déficit transmite do objeto da política habitacional. Ao reduzir o direito à moradia a um número, o conceito dá a idéia de que o objeto da política é um produto de prateleira, similar a qualquer outra mercadoria produzida pelo sistema. A Fundação João Pinheiro, em documento recente, aponta que o termo déficit "induz equivocadamente à expectativa de enfrentar o problema da moradia de forma setorial. Além disso, camufla uma complexa realidade, por meio de uma quantificação padronizada, atemporal e neutra"17 . Já o conceito de necessidades habitacionais, desenvolvido pela Fundação no começo dos anos 90 e consubstanciado em documento de $1995^{18}$, parece-nos mais adequado para analisar a parte mais visível da urbanização brasileira. O dimensionamento das Necessidades Habitacionais engloba não apenas a necessidade de produção de novas unidades, mas também a adequação, a melhoria, a qualificação das unidades existentes, incorporando dessa forma uma dimensão urbana, ainda que restrita, à moradia, como veremos abaixo.

O documento Déficit Habitacional no Brasil 2007, elaborado pela Fundação João Pinheiro para o Ministério das Cidades, analisa as necessidades habitacionais do país a partir dos dois 'segmentos de análise': o déficit habitacional e as inadequações dos domicílios.

17 BRASIL. Ministério das Cidades. Secretaria Nacional de Habitação. Déficit habitacional no Brasil 2007. Brasília: Ministério das Cidades/Secretaria Nacional de Habitação, 2009.

18 Ver documento "Déficit Habitacional no Brasil - 1995", editado pela Fundação João Pinheiro. 
A metodologia da FJP conceitua então déficit como a "noção mais imediata e in-

tuitiva de necessidade de construção de novas moradias para a solução de problemas sociais e específicos de habitação detectados em certo momento". A inadequação de moradias, por sua vez, considera no âmbito de necessidades habitacionais o parque já construído de milhares de unidades habitacionais, que devem na verdade sofrer outro tipo de intervenção que não sua pura e simples reposição. "O conceito de inadequação de moradias reflete problemas na qualidade de vida dos moradores: não estão relacionados ao dimensionamento do estoque de habitações e sim a especificidades internas do mesmo. Seu dimensionamento visa ao delineamento de políticas complementares à construção de moradias, voltadas para a melhoria dos domicílios existentes" (Brasil, 2009, p.15).

A necessidade de construção de novas unidades advém de uma série de fatores:

- Coabitação familiar forçada (Famílias conviventes secundárias com intenção de constituir domicílio exclusivo);

- Moradores de baixa renda sem condições de suportar o pagamento de aluguel (ônus excessivo com aluguel);

- Moradores de baixa renda que vivem em casas e apartamentos alugados com grande densidade de pessoas (Domicílios alugados com adensamento excessivo de moradores por dormitório);

- Moradia em imóveis e locais com fins não residenciais (domicílios improvisados)

- Cômodos alugados e cedidos (domicílios improvisados);

- Domicílios rústicos.

Os quatro primeiros itens são conceituados pela FJP como "déficit por incremento do estoque" e o último por "déficit por reposição de estoque".

De acordo com a pesquisa efetuada, tendo por base a PNAD 2007, "o déficit habitacional estimado em 2007 é de 6,273 milhões de domicilios, dos quais 5,180 milhões, ou $82,6 \%$, estão localizados nas áreas urbanas. Relativamente, corresponde a 11,1\% do estoque de domicílios particulares permanentes do país, sendo 10,8\% nas áreas urbanas e 12,9\% nas rurais". (Brasil, 2009, p.24). 
Portanto, aproximadamente, mais de $10 \%$ do estoque de domicílios do país deve

ser construído para que a necessidade de novas habitações seja atendida. No entanto, conforme foi apresentado anteriormente, essas novas unidades habitacionais vêm de diferentes realidades urbanas e sociais, o que demanda diferentes tipologias habitacionais e arquiteturas financeiras para que o problema possa de fato ser resolvido. Afinal a política pública que visa construir uma unidade para repor um domicílio rústico que muito provavelmente se encontra em um "aglomerado subnormal", como discrimina o IBGE, é muito distinta da política pública destinada a promover o incremento de estoque habitacional para uma família oriunda de uma

TABELA 9

Déficit Habitacional (1) e percentual em relação aos domicílios particulares permanentes, por situação do domicílio, segundo regiões geográficas, Unidades da Federação e Regiões Metropolitanas (RMs) - Brasil $-2007$.

\begin{tabular}{|c|c|c|c|c|c|c|c|c|}
\hline & \multicolumn{4}{|c|}{ DÉFICIT HABITACIONAL } & \multicolumn{4}{|c|}{$\begin{array}{l}\text { PERCENTUAL DOS DOMICÍLIOS } \\
\text { PARTICULARES PERMANENTES }\end{array}$} \\
\hline & \multirow[b]{2}{*}{ Total } & \multirow[b]{2}{*}{ urbana } & \multicolumn{2}{|c|}{ rural } & \multirow[b]{2}{*}{ total } & \multirow[b]{2}{*}{ urbana } & \multicolumn{2}{|c|}{ rural } \\
\hline & & & total & $\begin{array}{l}\text { rural de } \\
\text { extensão } \\
\text { urbana }\end{array}$ & & & total & $\begin{array}{c}\text { rural de } \\
\text { extensão } \\
\text { urbana }\end{array}$ \\
\hline Brasil & 6.272 .645 & 5.179 .763 & 1.092 .882 & 20.613 & 11,1 & 10,8 & 12,9 & 7,1 \\
\hline Total RMs & 1.855 .399 & 1.810 .662 & 44.737 & 7.774 & 10,5 & 10,5 & 8,9 & 5,7 \\
\hline Demais áreas & 4.417 .246 & 3.369 .101 & 1.048 .145 & 12.839 & 11,4 & 11 & 13,1 & 8,4 \\
\hline
\end{tabular}

Extraído de: BRASIL. Ministério das Cidades. Secretaria Nacional de Habitação. Déficit habitacional no Brasil 2007. Ministério das Cidades. Secretaria Nacional de Habitação. Brasília,2009.

Fonte: Dádos básicos: Instituto Brasileiro de Geografia e Estatística (IBGE). Pesquisa Nacional por Amostra de Domicílios (Pnad), 2007.

TABELA 10

Distribuição percentual do déficit habitacional urbano (1) por faixas de renda média familiar mensal, segundo regiões geográficas, Unidades da Federação e Regiões Metropolitanas (RMs) - Brasil - 2007.

\begin{tabular}{|l|ccccccc|}
\hline & \multicolumn{7}{|c|}{ FAIXAS DE RENDA MÉDIA FAMILIAR MENSAL } \\
\hline & até 2 S.M. & $\begin{array}{c}>\text { 2 a 3 } \\
\text { S.M. }\end{array}$ & $\begin{array}{c}>\text { S.M. } 6 \\
\text { S.M. }\end{array}$ & $\begin{array}{c}\text { S.M. } 8 \\
\text { S.M. }\end{array}$ & $\begin{array}{c}>8 \text { a } 10 \\
\text { S.M. }\end{array}$ & > 10 S.M. & Total (2) \\
\hline Brasil & 73,4 & 16 & 8,1 & 1,1 & 0,4 & 1 & 100 \\
\hline Total das RMs & 69,2 & 18,1 & 9,2 & 1,6 & 0,7 & 1,2 & 100 \\
\hline
\end{tabular}

Extraído de: BRASIL. Ministério das Cidades. Secretaria Nacional de Habitação. Déficit habitacional no Brasil 2007. Ministério das Cidades: Secretaria Nacional de Habitação: Brasília, 2009.

Fonte: Dádos básicos: Instituto Brasileiro de Geografia e Estatística (IBGE). Pesquisa Nacional por Amostra de Domicílios (Pnad), 2007. Nota: no cálculo do déficit habitacional o componente coabitação familiar inclui apenas as famílias conviventes que declararam intenção de constituir novo domicílio; (1) Inclusive Rura de extensão urbana; (2) Exclusive sem declaração de renda. 
coabitação familiar forçada. São distintas realidades sociais que demandam distintas tipologias habitacionais e, no caso específico dessa tese, distintas políticas de acesso à moradia.

Dos critérios que compõem o déficit, a coabitação familiar é "o fator que mais contribui em números absolutos para o cálculo do déficit habitacional, exceto na região Sudeste" (BRASIL, 2009, p.42). Na região Sudeste o que contribui para o déficit é o ônus excessivo com aluguel: "são mais de 1,133 milhão de famílias urbanas, ou 51,1\% do total das que comprometem grande parcela da renda com aluguel. A maioria delas está localizada em São Paulo e sua região metropolitana" (Brasil, 2009, p.42). O próprio documento comenta a especificidade desse indicador para São Paulo, relacionando-o com outras regiões metropolitanas: "Por ser um indicador que reflete a dificuldade do mercado imobiliário em se adequar ao perfil de demanda da população, espera-se que tenha maior peso nos grandes centros urbanos" (Brasil, 2009, p.42).

Observando-se que o déficit habitacional está concentrado na faixa de 0 a 3 salários e que, especialmente na região sudeste, $51,1 \%$ das famílias compromete parcela expressiva de sua renda com aluguel e que esse número vem aumentando (3\% percentual em relação aos domicílios particulares permanentes em 2000 e 4,8\% em 2007), pode-se inferir que o acesso à moradia digna a essa faixa de renda merece de fato um tratamento diferenciado, e não parece factível nem razoável esperar que do desenvolvimento de um mercado de recebíveis imobiliários advenha recursos financeiros para fazer frente a essa situação.

TABELA 11

Critérios de inadequação dos domicílios urbanos duráveis (1), segundo regiões geográficas e Regiões Metropolitanas (RMs) - Brasil - 2007.

\begin{tabular}{l|ccccc|}
\hline ESPECIFICAÇÃO & $\begin{array}{c}\text { Inadequação } \\
\text { Fundiária }\end{array}$ & $\begin{array}{c}\text { Domicílio sem } \\
\text { banheiro }\end{array}$ & $\begin{array}{c}\text { Carência de Infra- } \\
\text { estrutura }\end{array}$ & $\begin{array}{c}\text { Adensamento } \\
\text { Excessivo }\end{array}$ & $\begin{array}{c}\text { Cobertura } \\
\text { Inadequada }\end{array}$ \\
\hline Brasil & 1.879 .907 & 928.777 & 10.454 .947 & 1.500 .709 & 543.066 \\
\hline Total das RMs & 1.031 .059 & 183.968 & 2.383 .349 & 669.223 & 148.589 \\
\hline
\end{tabular}

Extraído de: BRASIL. Ministério das Cidades. Secretaria Nacional de Habitação. Déficit habitacional no Brasil 2007. Ministério das Cidades. Secretaria Nacional de Habitação. Brasília,2009.

Fonte: Dádos básicos: Instituto Brasileiro de Geografia e Estatística (IBGE). Pesquisa Nacional por Amostra de Domicílios (Pnad), 2007. Nota: (1) Apenas domicílios duráveis, ou seja, não são considerados os improvisados e os rústicos, sendo excluídos também os cômodos, por se constituirem parcela do déficit habitacional. Inclui, além dos domicílios urbanos, os rurais de extensão urbana. 
TABELA 12

Domicílios particulares permanentes e distribuição percentual por situação do domicílio, segundo regiões geográficas, unidades da federação e regiões metropolitanas (RMs) - Brasil -2007.

\begin{tabular}{|c|c|c|c|c|c|c|c|c|}
\hline & \multicolumn{5}{|c|}{ Domicilios Particulares Permanentes } & \multicolumn{3}{|c|}{ Distribuição percentual } \\
\hline & \multirow[b]{2}{*}{ Total } & \multirow[b]{2}{*}{ urbana } & \multicolumn{3}{|c|}{ Rural } & \multirow[b]{2}{*}{ total } & \multirow[b]{2}{*}{ urbana } & \multirow[b]{2}{*}{ rural } \\
\hline & & & total & $\begin{array}{l}\text { rural de } \\
\text { extensão } \\
\text { urbana }\end{array}$ & $\begin{array}{c}\text { demais } \\
\text { areas rurais }\end{array}$ & & & \\
\hline Brasil & 56.344 .188 & 47.855 .551 & 8.488 .637 & 290.119 & 8.198 .518 & 100 & 100 & 100 \\
\hline Total das RMs & 17.709 .465 & $\mid 17.209 .206$ & 500.259 & 137.358 & 362.901 & 31,4 & 36 & 5,9 \\
\hline Demais áreas & 38.634 .723 & 30.646 .345 & 7.988 .378 & 152.761 & 7.835 .617 & 68,6 & 64 & 94,1 \\
\hline
\end{tabular}

Extraído de: BRASIL. Ministério das Cidades. Secretaria Nacional de Habitação. Déficit habitacional no Brasil 2007. Ministério das Cidades. Secretaria Nacional de Habitação. Brasília,2009.

Fonte: Dádos básicos: Instituto Brasileiro de Geografia e Estatística (IBGE). Pesquisa Nacional por Amostra de Domicílios (Pnad), 2007.

A inadequação dos domicílios também corrobora essa tese. Os domicílios considerados inadequados pela pesquisa da FJP são 21,7\% dos domicílios urbanos em 2007. Ou seja, mais de um quinto dos domicílios urbanos apresentam problemas tais como carência de infra-estrutura, adensamento excessivo de moradores, problemas de natureza fundiária, cobertura inadequada, falta de unidade sanitária domiciliar exclusiva ou alto grau de depreciação.

São nessas cidades, com esse grau de desigualdade e com essa distribuição de renda que serão feitos os investimentos em crédito imobiliário visando o retorno ao investidor, como vimos no capítulo anterior. Como é possível, portanto, com esse padrão de necessidades habitacionais, decorrentes do padrão de urbanização brasileira, que o modelo preconizado no SFI venha a atender à demanda habitacional tal como ela se apresenta no Brasil?

Os investimentos imobiliários, por sua natureza intrínseca, devem dar o retorno esperado pelo investidor, ainda que essa taxa de retorno seja considerada 'conservadora' para os parâmetros do mercado de capitais. "Desse modo, a feição da cidade e o modo como é produzida alteram-se visivelmente quando esses empreendimentos constituem-se como atrativas aplicações financeiras. A lógica de sua produção passa a ser regida pelos interesses de rentabilidade dos investidores, sejam eles fundos de pensão sejam fundos de investimentos imobiliários" (Fix, 2001, 113), aponta Fix na obra em que nos apresenta como essa lógica dos investimentos imobiliários vem junto com 
o aumento das ocupações irregulares e aumento das necessidades habitacionais e não o inverso.

Resta a questão - o que significaria implementar o building institutions for markets no setor habitacional em um país com essas características urbanas e habitacionais? O que a experiência demonstra é que o modelo, com suas agendas objetivas e enxutas, devidamente traduzidas para a linguagem das instituições brasileiras por universidades e setores empresariais, quando se depara com uma sociedade urbana complexa, profundamente desigual, tende a aprofundar ainda mais este quadro desalentador, visto que as necessidades habitacionais, que essa agenda em princípio deveria resolver, passam bem longe do desejo dos investidores.

Neste sentido, é possível concluir que este modelo não é capaz de atingir o 'coração' do déficit habitacional brasileiro, por conta de suas características estruturais. Mesmo assim, a disputa pelos recursos públicos promovida por agentes financeiros é cada vez mais acirrada.

De acordo com o diretor da holding Brazilian Finance \& Real Estate, discorrendo sobre os próximos passos da estruturação de um potente mercado secundário de títulos imobiliá-rios:

Ficamos sete anos discutindo com a CVM a possibilidade de termos um fundo imobiliário de CRI, de LH e LCl, que vai dar um dinamismo enorme. Pode até criar um mercado secundário de CRI, e é o que a gente sempre apostou. Daqui a um tempinho você vai ver esse produto sendo lançado. É a nossa maior aposta a partir de agora. Aliado à redução da taxa de juros, vai ser o grande e novo boom ${ }^{19}$.

Esse fundo consta das agendas tanto do Banco Mundial quanto dos representantes do capital imobiliário. Mas não é só.

Em 2008, por meio da Resolução n 578, o CCFGTS aprovou uma linha de crédito destinada a aquisição de CRI no valor total de 3 bilhões de reais. O Relatório de Administração do Exercício de 2008 do FGTS aponta essa linha de crédito como mais 
uma iniciativa para "contribuir para o combate ao déficit habitacional no país" 20 . Essa autorização de gastos é para o ano de 2009, destinada a adquirir cotas de Fundos de Investimento Imobiliário - Fll, de Fundos de Investimentos Creditórios - FIDC, debêntures e Certificados de Recebíveis Imobiliários - CRI, que tenham como lastro operações de habitação lançadas por incorporadoras, empresas da construção civil, Sociedades de Propósitos Específicos - SPE, cooperativas habitacionais ou entidades afins ${ }^{21}$.

Enfim, a despeito da inadequação do modelo para zerar o déficit habitacional por conta das características estruturais do processo de urbanização no Brasil, o SFI e os novos instrumentos de crédito continuam a ser defendidos como o arranjo mais a-dequado para enfrentar as necessidades habitacionais da sociedade brasileira. Neste processo geral de falsificação, não é possível ignorar a maior de todas elas, que se soma ao poder retórico do déficit habitacional e à força ideológica da habitação como pretexto de captura do sistema de crédito - a universalização do direito à moradia como um direito social... para inglês ver.

Afinal, para o Banco Mundial e para todas as organizações "market-oriented" o problema habitacional não é exatamente uma questão de direito social, mas sim um problema de crédito, de renda, enfim, um problema individual do cidadão consumidor.

20 Ver Demonstrações Contábeis do FGTS - Relatório de Administração - Exercício. Disponível em $<$ http://www.caixa.gov.br/fgts $>$.

21 Resolução CCFGTS n 578 dezembro de 2008. Disponível em < http://www.mte.gov.br>. 


\section{CONCLUSÃO}


Ao longo de todo trabalho, procuramos realçar a íntima vinculação entre os modelos de

financiamento imobiliário no Brasil e os distintos padrões de intervenção do Estado no domínio econômico. Assim, de um lado, analisamos a estrutura e a operação do Sistema Financeiro de Habitação, calcado no crédito dirigido e na formatação de um funding composto por recursos públicos, recursos privados e recursos paraestatais. De outro, examinamos a construção do Sistema Financeiro Imobiliário, calcado na captação de recursos no mercado de capitais e no protagonismo do mercado na alocação dos recursos destinados ao setor. Em um e outro caso, buscamos compreender, a partir dos resultados apresentados, a vocação da política estruturada sob seus fundamentos.

Além disso, buscamos compreender também, na análise dos modelos, a participação do Estado e do mercado na organização dos sistemas. A criação do SFH, bem como a sua operacionalização em mais de quarenta anos, demonstra com muita propriedade a importância do Estado na instituição e na articulação nacional do sistema de crédito habitacional. Os números, as estatísticas, a evolução institucional, a arquitetura financeira - são vários os fatores que demonstram a magnitude do sistema e o papel fundamental do Estado na dinamização do setor imobiliário e das políticas públicas de habitação no Brasil. O SFI, por sua vez, apesar de aparentemente renegar a importância do Estado na formatação do setor, também evidencia, a seu modo, a importância do Poder Público na estruturação dos mercados, especialmente nos países periféricos, em que o processo de acumulação sempre dependeu do impulso estatal e da oferta de garantias institucionais ao seu pleno funcionamento. Assim, pudemos observar que, apesar da ambigüidade retórica, a política elaborada a partir da lei no 9.514/1997 não ousou propor o fim do SFH ou negar o crédito dirigido como um importante agente de acumulação do setor imobiliário no Brasil.

A intervenção do Estado em prol da acumulação de capital e da apropriação privada do excedente, no entanto, não é um traço inovador dos sistemas de financiamento da habitação no Brasil. A modernização conservadora consolidada após o golpe de 1964 escancarou o papel do fundo público na formação do capital industrial e mesmo de serviços no Brasil. A acumulação de capital na periferia sempre teve o Estado como alavanca. Desta forma, o discurso do protagonismo do mercado para a solução do déficit habitacional brasileiro não pode ser compreendido senão como um processo de falsificação. Falsificação pelo que critica - um Estado de Bem Estar que nunca existiu. Falsificação pelo que predica - a capacidade deste mercado habitacional ávido por recursos públicos resolver um problema crônico como o déficit habitacional.

A ideologia individualista, embutida neste processo de falsificação e emaranhada no rescaldo do processo de reestruturação produtiva e no processo de globalização dos mercados, teve um impacto muito forte no desenho das políticas públicas. A suposta eficiência dos mercados na solução de conflitos, ou como forma de acesso a bens e serviços nunca univer- 
salizados no país, interditou o debate político com a defesa de um Estado mínimo e com a defesa inconteste da exuberância da economia de mercado. Na periferia do capitalismo, em que o processo de acumulação sempre teve uma face visível na atuação do Estado sobre o domínio econômico, este discurso anti-estatal gerou efeitos contraditórios. Afinal, seria possível prescindir, do dia para a noite, do ente público responsável pela organização da acumulação de capital até então? E mais: seria possível apostar na superioridade do mercado para a universalização de um direito e para atacar um problema social crônico, cujas raízes remontam a um processo histórico de formação nacional excludente e anti-social? Ou, em outra chave, seria possível delegar ao mercado decisões fundamentais como as atinentes ao padrão de urbanização do país e do acesso à moradia pela população?

Após analisar o desenho e o desempenho do SFH e do SFI a elegia do "mais mercado, menos Estado" acaba soando ora como cinismo, ora como mistificação. Cinismo por reconhecer que, de fato, é insustentável universalizar o direito à moradia e que alguns permanecerão excluídos, independentemente do êxito da política. Mistificação por ignorar a insuficiência histórica do mercado habitacional brasileiro, inerte sem aportes substantivos de recursos estatais. Neste sentido, apostar na eficiência dos mercados como antídoto à ineficiência da política não só obscurece os sentidos da política habitacional brasileira dos últimos cinqüenta anos como reduz a solução de um problema extremamente complexo à simples criação de um ambiente de negócios favorável à acumulação de capital.

Para atenuar os riscos no ambiente de negócios do SFI, é sempre apresentada a proposta de criação de fundos de fomento e liquidez, fundos garantidores, ou fundos estatais, conforme apresentado no capítulo 3. A criação desses fundos, cuja função seria a ampliação da segurança e a atração de investidores na securitização, continua fazendo parte de agendas setoriais e é defendida veementemente. De acordo com a FGV, a "ampliação das atividades pode acontecer pelo aumento das operações até mesmo com créditos emitidos originalmente no âmbito do SFH" (FGV Projetos, 2007, p. 45) A questão preocupante é a origem, o volume, a abrangência e a destinação desses fundos. O desenvolvimento econômico brasileiro demonstra que a constituição e fortalecimentos dos mercados se dão na captura do orçamento público. Dessa forma, a criação de fundos destinados a dar suporte ao funcionamento de um mercado secundário de hipotecas sob o argumento de que o SFI tem como um de seus princípios básicos "a desoneração dos cofres públicos" (CIBRASEC, 2005), deve ser avaliada e acompanhada para que a disputa sobre os recursos não retire dos fundos justamente o recurso que é necessário para o atendimento às necessidades habitacionais brasileiras, das quais aproximadamente $90 \%$, setores importantes do próprio mercado imobiliário dizem que não tem como atender.

De fato "não se obtém sucesso na redução do déficit habitacional para a população de baixa renda sem a participação do governo no setor de financiamento imobiliário" (Carneiro;Valpassos, 
2003, p.68). Mas mesmo assim, alguns autores ainda insistem em retirar exemplos modelares de outros países nos quais "observam-se [...] amplas linhas de subsídios públicos que permitem a captação pelo mercado dos recebíveis referentes aos financiamentos feitos para a aquisição de imóveis por parte da população de baixa renda". O objetivo do SFI então seria o de "ligar os maiores poupadores da nossa economia, que são os fundos de pensão, seguradoras e outras instituições que demandam ativos de longo prazo aos indivíduos demandantes de créditos imobiliários, que se apresentam em grande número em todo território nacional" (Carneiro;Valpassos, 2003, p.68). Dessa forma, poderíamos entender que então os recursos oriundos do mercado secundário seriam carreados para quem pode pagar as taxas de juros atrativas para esses investidores. Só que então, mais uma vez, surge o argumento da baixa renda e do déficit, visto que o Estado é chamado a participar com o que tem de melhor, o fundo público, no subsídio à taxa de juros e também na criação de seguros de crédito visto que "o resultado da ineficiência atual é o fechamento do mercado privado para financiamentos de baixo valor, excluindo a população carente de qualquer possibilidade de adquirir um imóvel" (Carneiro;Valpassos, 2003, p.69). O embaralhamento dos argumentos, misturando o déficit habitacional, o acesso das faixas de renda mais baixas à moradia digna, o fomento ao mercado imobiliário, a implantação de um mercado de capitais forte com instrumentos sofisticados de títulos de recebíveis de crédito imobiliário buscam confundir e fortalecer o argumento da participação do governo no estabelecimento do mercado secundário de recebíveis como um fim em si mesmo e demonstram o caráter ideológico do discurso.

Neste processo, a tentativa de substituir um modelo de financiamento baseado na intensiva participação estatal para um modelo de financiamento "market-oriented" abusa da retórica, como, por exemplo, quando critica o caráter simplório do modelo de crédito habitacional brasileiro, assentado na poupança como grande funding das operações. Todavia, no lugar de abandonar esta fonte privilegiada de recursos, como o argumento poderia sugerir, o que se observa nos últimos anos é a resistência desta base de financiamento. O desempenho recente do SFH, tanto do SBPE quanto do FGTS ilustra bem a questão. As mudanças nas condições de acesso ao crédito, bem como a inegável melhoria nas condições macroeconômicas para o crédito de longo prazo, conseguiram ampliar o acesso ao crédito habitacional. Desta forma, é sintomática a pressão exercida por setores imobiliários visando a diminuição do controle estatal sobre o crédito dirigido (do direcionamento da poupança à flexibilização do uso do FGTS), condição necessária ao fortalecimento do mercado de capitais como fonte privilegiada de financiamento, com isenções de impostos e atração de investidores.

Por ocasião da criação do SFI, não faltaram os que criticassem o SFH como ultrapassado, defendendo a sua substituição para que finalmente o problema habitacional fosse resolvido. E as críticas mais aguçadas ao SFH, que apontava os problemas e a regressividade no seu 
modelo de subsídios, demonstrando suas inegáveis limitações no equacionamento das necessidades habitacionais brasileiras, passaram a ser utilizadas para justificar a transição para o modelo do SFI. Passados dez anos da sua aprovação, é possível perceber que, mais do que substituir o SFH, que os defensores do novo modelo vislumbram é acessar os recursos que historicamente financiaram a política de habitação no Brasil. Só assim podemos compreender a fala da presidência da ABECIP em 2005: "Os recursos serão mobilizados, principalmente, com a colocação de Certificados de Recebíveis Imobiliários (CRIs) emitidos pelas companhias securitizadoras. Estas empresas adquirirão os créditos gerados no Sistema Financeiro da Habitação (SFH). O papel do SFH estará, então, limitado à produção e geração de CRIs para o mercado secundário, que será o verdadeiro propulsor do crédito imobiliário" (ABECIP, 2005, p. 48).

Neste sentido, apesar do foco mais expressivo do SFI no financiamento de imóveis não-residenciais, a habitação acabou virando um excelente pretexto para o discurso da alocação de recursos do SFH na promoção de produtos imobiliários em geral, por meio do ambiente de negócios do SFI. Entre vários argumentos, o mais importante diz respeito à natureza dos recursos do SBPE e do FGTS, que, por serem pró-cíclicos, seriam instáveis, dependentes do cenário macroeconômico do país e das políticas de emprego e renda. Ora, a instabilidade inerente do mercado de capitais obviamente acompanha as empresas imobiliárias e influencia sobremaneira os investidores focados nos títulos creditícios de base imobiliária. Desta forma, a alternativa de captação de recursos junto ao mercado parece não resolver, mas sim aprofundar essa característica de instabilidade de fluxo de recursos.

Este processo de requalificação do papel Estado e do mercado na promoção de políticas públicas envolveu, no caso da habitação, uma transformação do direito universal de acesso à moradia em uma possibilidade individual de acesso ao crédito habitacional. Neste contexto, o discurso financeiro emerge como um discurso neutro, sustentando que o modelo veiculado, quando estruturado em bases equilibradas, é capaz de suportar qualquer política pública No caso da habitação, por conta dos imensos desequilíbrios financeiros ocorridos na década de 80 no SFH e por causa do passivo que a União herdou no FCVS, conforme visto no capítulo 2, a organização de um sistema equilibrado parecia a panacéia contra as iniqüidades do período anterior. Não se defende aqui, obviamente, a irresponsabilidade quanto à sustentação material das políticas de bem estar. No entanto, não é possível ignorar que, apesar da incontestável necessidade de sustentabilidade financeira, a principal questão na formulação de um sistema de provisão de direitos, como a habitação, deve ser a universalização e não somente o equilíbrio. Acentuando a ótica da equação renda x consumo e não a ótica do direito, o discurso financeiro catalisa o processo de mercadorização da habitação, nos termos apresentados por David Harvey, discutidos no capítulo 1.

A transformação de uma questão social - a universalização de um direito - em um pro- 
blema individual é fruto da matriz teórica dos novos modelos de financiamento da política de habitação. Nesta perspectiva, a afirmação do discurso neoclássico no Brasil expõe sua própria fragilidade metodológica. Ao reduzir a importância da participação ativa do Estado na constituição e manutenção das economias de mercado, o referido discurso limita as análises econômicas à alocação eficiente dos recursos no mercado, cedendo pouco espaço às variáveis históricas e políticas. Consequentemente, o cidadão beneficiário de direitos passa a ser encarado como um consumidor e a questão habitacional, como uma questão individual de quem pode ou não pode tomar crédito, de quem pode ou não oferecer garantia contra os riscos temidos pelos agentes financeiros. O Estado, a quem deveria competir organizar o desenvolvimento social, garantindo o acesso universal à moradia, limita-se a corrigir as decantadas falhas de mercado, sustentando a suposta excelência da racionalidade econômica.

Uma conseqüência grave da recepção hegemônica do pensamento neoclássico é a simplificação do problema habitacional à questão individual, ignorando a perspectiva do conflito e o fato da apropriação do excedente refletir um sistema social estratificado e hierarquizado. As políticas públicas são manejadas por agentes econômicos, que fazem escolhas racionais diante da possibilidade de usos alternativos de bens escassos. Ora, será possível reduzir o problema habitacional a uma relação entre um agente racional e um bem escasso, desconsiderando o conflito como categoria essencial da política? Será possível pensar a habitação no Brasil em um contexto neutro?

Celso Furtado, ao apontar as vicissitudes do processo de acumulação no Brasil, sublinhava a insuficiência dos nossos mercados, fragilizados pelo deslocamento dos centros decisórios para fora do território nacional. Em um país com as características de 'mercado travado' como o brasileiro, com a dimensão da 'tragédia urbana brasileira', segundo Maricato, ignorar a natureza conflituosa do direito à moradia e reduzir o Estado a um simples agente econômico que corrige 'eventuais' falhas de mercado é desconhecer o processo histórico de formação da sociedade brasileira e apostar na falsificação como base de disseminação de um discurso econômico que só se sustenta como ideologia.

Neste contexto, a política habitacional deve, longe de se limitar ao papel regulatório do mercado de crédito, re-incorporar o conflito na estruturação do sistema de crédito, reconhecer os conflitos distributivos e socorrer de maneira desigual os grupos de menor renda. Certamente a alocação eficiente de recursos tem parcela de importância na implementação e operação cotidiana dos programas, mas é estéril enquanto centro (core) de uma formulação de política que pretenda universalizar direitos. Todo o processo urbano, a questão locacional da moradia, a questão fundiária, a urbanização de áreas degradadas, a diversidade do atendimento habitacional e do acesso à moradia digna devem ser tratados de forma integrada, reconhecendo os interesses em disputa e arbitrando os 'ganhadores' da política 
Por fim, do nosso ponto de vista, um dos efeitos mais graves da esterilização da política habitacional foi o rebaixamento do horizonte utópico da política. No Brasil nunca houve Estado de Bem Estar Social propriamente dito. No entanto, a Constituição brasileira, considerada de fato avançada em relação às Cartas Magnas de muitos países, consagrou a moradia como direito fundamental, estabelecendo uma meta a ser atingida pela sociedade brasileira: a universalização do direito à moradia digna. Ousou elevar a meta da política, retirando a conotação individual da habitação como um problema exclusivo dos sem-teto. A razão cínica que motiva este processo de falsificação, no entanto, tratou de desfazer esta ilusão em detrimento da constatação pura e simples de que os direitos são distribuídos a quem esteja devidamente qualificado pelo mercado para recebê-lo. Reconhecer a insuficiência do SFI para atacar o déficit habitacional, desvendando as mistificações que coalham a suas justificativas, deve, por isso, sustentar o processo de ressignificação da política habitacional e do sentido do direito à moradia como direito fundamental. 


\section{BIBLIOGRAFIA}


ABECIP. História e Perspectivas do Crédito Imobiliário - ABECIP 36 anos. São Paulo: ABECIP, 2003.

ABECIP; CBIC. Primeira Revisão Trimestral da Proposta Acordada entre a ABECIP - Associação Brasileira das Entidades de Crédito Imobiliário e a CBIC - Câmara Brasileira da Indústria da Construção. São Paulo: CBIC, abr 2005. Disponível em http://www.cbic.org.br/arquivos/acordoABECIPCBIC.pdf. Acesso em março de 2009.

ACCENTURE. Crédito Imobiliário: Propostas para Torná-lo um Efetivo Instrumento Promotor do Desenvolvimento Econômico e Social do País. In: BANCO CENTRAL DO BRASIL. Conferência Internacional de Crédito Imobiliário; nov. 2007, Salvador, Brasil.

ALBUQUERQUE, Marcus Cintra. Habitação popular: avaliação e propostas de reformulação do Sistema Financeiro da Habitação. In: Reestruturação do Estado? Hipóteses a partir de um caso: a política nacional de habitação. Campinas: UNICAMP/NEPP, 1991.

ALVES, Paulo Roberto Rodrigues. O Desenvolvimento do Sistema Financeiro Imobiliário e da Securitização de Recebíveis Imobiliários na Redução do Déficit Habitacional Brasileiro. 2005. Monografia apresentada ao Instituto de Economia da Universidade Federal do Rio de Janeiro para obtenção do título de bacharel em economia. Disponível em < $\underline{\text { http://www.cvm. }}$ gov.br/port/public/publ/ie ufrj cvm/Paulo Roberto Rodrigues Alves.pdf. $>$ Acesso em maio de 2009.

AMENDOLARA, Leslie; RUDGE, Luiz Fernando. Desvendando a rede dos financiamentos imobiliários. São Paulo: Pini; O Nome da Rosa, 1997.

ANAIS DO SEMINÁRIO INTERNACIONAL DE CRÉDITO IMOBILIÁRIO. As Contribuições dos Sistemas Imobiliários da Espanha e do México para o Aperfeiçoamento do Modelo Brasileiro. Rio de Janeiro: ABECIP/Publitetto, 2007.

ANDRADE, Luís Aureliano. Política urbana no Brasil: o paradigma, a organização e a política. Estudos CEBRAP, São Paulo, no. 18, p.117-148, out/dez 1976.

ARAGÃO, José Maria. Sistema Financeiro da Habitação: uma Análise Sócio-Jurídica da Gênese, Desenvolvimento e Crise do Sistema. Curitiba: Juruá, 1999.

ARRETCHE, Marta. Aspectos Regionais dos Gastos com Habitação e Saneamento Básico. In: AFFONSO, Rui de Britto A.; SILVA, Pedro Luiz B. (Orgs.). Descentralização e Políticas Sociais. São Paulo: FUNDAP, 1996.

Desarticulação do BNH e autonomização da política habitacional. In: AFFONSO, Rui de Britto A.; SILVA, Pedro Luiz B. (Orgs.). Descentralização e Políticas Sociais. São Paulo: 
. Intervenção do Estado e setor privado: o modelo brasileiro de política habitacional. Espaço e Debates, São Paulo, v. 10 , no. 31, p.21-36, 1990.

Política Habitacional entre 1986 e 1994. In: ARRETCHE, Marta; RODRIGUEZ, Vicente (Orgs.). Descentralização das Políticas Sociais no Estado de São Paulo. São Paulo: FUNDAP/ FAPESP; Brasília: IPEA, 1998.

; RODRIGUEZ, Vicente. Descentralização das Políticas Sociais no Estado de São Paulo. In: ARRETCHE, Marta; RODRIGUEZ, Vicente (Orgs.) Descentralização das Políticas Sociais no Estado de São Paulo. São Paulo: FUNDAP/FAPESP; Brasília: IPEA, 1998.

ARRIGHI, Giovanni. O longo século XX: dinheiro, poder e as origens de nosso tempo. Rio de Janeiro: Contraponto; São Paulo: Editora UNESP, 1996.

AZEVEDO, Sérgio de. A crise da política habitacional: dilemas e perspectivas para o final dos anos 90. In: RIBEIRO, Luiz César de Queiroz. A crise da moradia nas grandes cidades: da questão da habitação à reforma urbana. Rio de Janeiro: Editora UFRJ, 1996, p. 73-104.

Política de Habitação Popular: equívocos e mitos sobre a autoconstrução. Revista de Administração Municipal, Rio de Janeiro, v. 36, no. 192, jul/set, 1989.

Vinte e dois anos de habitação popular (1964-1986): criação, trajetória e extinção do BNH. Revista de Administração Pública, Rio de Janeiro, v. 4, no. 22, p.107-119, out/dez, 1988.

.; ANDRADE, L. A. G. Habitação e Poder - Da fundação da casa popular ao Banco Nacional da Habitação. Rio de Janeiro: Zahar, 1982.

BALL, Michael. Housing Analysis: Time for a Theoretical Refocus? Housing Studies, Londres, vol 1, no. 3, 1986.

O desenvolvimento do capitalismo na provisão da habitação. Espaço e Debates, São Paulo, no. 36, 1992.

Recent changes in housing provision in Europe and the USA. In: Faculdade de Arquitetura e Urbanismo da Universidade de São Paulo. Workshop “Habitação: como ampliar o mercado?" 25 a 27 de agosto 2007, São Paulo, Brasil.

; Michael; HARLOE, Michael; MARTENS, Maartje. Housing and social change in Europe and in the USA. Londres: Routledge, 1988.

BAKER, Dean; BARIBEAU, Simone. Homeownership in a bubble: the fast path to poverty? Wash- 
ington: Center for Economic and Policy Research, 13 ago 2003. Disponível em <http://www. scribd.com/doc/3851/Homeownership-in-a-Bubble-The-Fast-Path-to-Poverty >. Acesso em junho 2009.

BALBI, Sandra. Bancos engordam lucros com poupança. Jornal Folha de São Paulo, São Paulo, 15 jul 2002.

BELLOTTO, Alessandra. Tijolo de papel. Jornal Valor Econômico, São Paulo, 30 de junho de 2009.

; COTIAS, Adriana. Com nova instrução, CVM busca destravar o mercado. Jornal Valor Econômico, São Paulo, 03 nov 2008.

BELLUZZO, Luiz Gonzaga. As Armadilhas da Liquidez. Jornal Valor Econômico. São Paulo, 21 ago 2007, p. 20.

Dinheiro e as transfigurações da riqueza. In TAVARES, Maria da Conceição; FIORI, José Luís (Orgs.). Poder e Dinheiro: uma economia política da globalização. Petrópolis: Vozes, 1997, pp.151-194.

Finança Global e Ciclos de Expansão. In FIORI, José Luís (Org.) Estados e Moedas no Desenvolvimento das Nações. Petrópolis: Vozes, 1999, pp. 87-117.

Prefácio. In CHESNAIS, François (Org.). A Finança Mundializada: raízes sociais e políticas, configuração, conseqüências. São Paulo: Boitempo, 2005, pp. 7-17.

BINKOWSKI, Grazieli Inticher. CRI: emissões crescem, mas não contemplam investidor de varejo. Acionista.com.br .Porto Alegre, 31 jul 2008. Disponível em <http://www.acionista.com. br/home/investimentos/310708 cri.htm >. Acesso em mar 2009.

BNH/AET/CEPAM. Programas Habitacionais de baixa renda, relatório de avaliação dos programas dos trabalhos realizados e resultados alcançados. mimeo s/n, s/l, s/d.

BOLAFFI, Gabriel. A casa das ilusões perdidas: aspectos sócio-econômicos do Plano Nacional de Habitação. São Paulo: Brasiliense/CEBRAP, 1977.

Aspectos sócio-econômicos do Plano Nacional de Habitação. 1972. 145p. Tese (Doutorado) - Faculdade de Arquitetura e Urbanismo, Universidade de São Paulo, São Paulo, 1972. Habitação e Urbanismo: o problema e o falso problema. Ensaios de Opinião, nº.02. Rio de Janeiro: Inúbia, 1975.

. Os mitos sobre o problema da habitação. Espaço e Debates. São Paulo: ano VI, nº.17, 
; CHERKEZIAN, Henry. Os caminhos do mal-estar social: habitação e urbanismo no Brasil. Novos Estudos CEBRAP, São Paulo, no. 50, 1988.

BONDUKI, Nabil. O boom imobiliário vai chegar à habitação de interesse social? Jornal O Estado de São Paulo, São Paulo, 15 jan 2008.

Habitação e Autogestão - construindo territórios de utopia. São Paulo: FASE, 1992.

O novo papel do município na questão da habitação. Revista Proposta. São Paulo, FASE, n. 77, 1998.

Origens da habitação social no Brasil. São Paulo: Estação Liberdade/FAPESP, 1998.

; ANDRADE, Carlos R. M.; ROSSETO, Rossella. Arquitetura e Habitação Social em São Paulo 1989-1992. São Carlos: USP, 1993.

BONELLI, Regis; RAMOS, Lauro. Distribuição de Renda no Brasil: avaliação das tendências de longo prazo e mudanças na desigualdade desde meados de 1970. Texto para discussão no 288. Brasília: IPEA, jan 1993.

BOTELHO, Adriano. O urbano em fragmentos: a produção do espaço e da moradia pelas práticas do setor imobiliário. São Paulo: Annablume; FAPESP, 2007.

BOTTOMORE, Tom (ed.). Dicionário do Pensamento Marxista. Rio de Janeiro: Zahar, 1988.

BRAGA, José Carlos de Souza. Financeirização global - O padrão sistêmico de riqueza do capitalismo contemporâneo. In TAVARES, Maria da Conceição; FIORI, José Luís (Orgs.). Poder e Dinheiro: uma economia política da globalização. Petrópolis: Vozes, 1997, pp. 195-242.

BRANCO, Pedro Paulo M. Habitação Popular e governo democrático. São Paulo em perspectiva. São Paulo, v. 1, nº. 3, set/out 1985.

BRASIL. Banco Central do Brasil. Sistema Financeiro da Habitação. Resumo Mensal do Setor - Dezembro de 2003. Disponível em <http://www.bcb.gov.br/fis/SFH/port/est2003/12/Resumo.pdf>. Acesso em março 2009.

Casa Civil da Presidência da República - Subchefia para Assuntos Jurídicos. Decreto no. 99.684, de 08 de novembro de 1990. Consolida as normas regulamentares do Fundo de Garantia do Tempo de Serviço (FGTS).

Casa Civil da Presidência da República - Subchefia para Assuntos Jurídicos. Decreto no. 4.378, de 16 de setembro de 2002. Aprova o regulamento do Conselho Curador do Fun- 
do de Compensação de Variações Salariais - CCFCVS.

Casa Civil da Presidência da República - Subchefia para Assuntos Jurídicos. Decretolei no. 2.406, de 5 de janeiro de 1988. Transfere a gestão do Fundo de Compensação de Variações Salariais (FCVS), do Banco Central do Brasil para o Ministério da Habitação, Urbanismo e Meio Ambiente e dá outras providências.

Casa Civil da Presidência da República - Subchefia para Assuntos Jurídicos. Lei no. 4.380, de 21 de agosto de 1964, Brasília. Institui a correção monetária nos contratos imobiliários de interesse social, o sistema financeiro para aquisição da casa própria, cria o Banco Nacional da Habitação (BNH), e Sociedades de crédito Imobiliário, as Letras Imobiliárias, o Serviço Federal de Habitação e Urbanismo e dá outras providências.

Casa Civil da Presidência da República - Subchefia para Assuntos Jurídicos. Lei no. 4.591, de 16 de dezembro de 1964, Brasília. Dispõe sobre o condomínio em edificações e as incorporações imobiliárias.

Casa Civil da Presidência da República - Subchefia para Assuntos Jurídicos. Lei no. 4.728, de 14 de junho de 1965. Disciplina o mercado de capitais e estabelece medidas para o seu desenvolvimento.

Casa Civil da Presidência da República - Subchefia para Assuntos Jurídicos. Lei no. 4.864, de 29 de novembro de 1965. Cria Medidas de estímulo à Indústria de Construção Civil.

Casa Civil da Presidência da República - Subchefia para Assuntos Jurídicos. Lei no. 5.107, de 13 de setembro de 1966, Brasília. Cria o Fundo de Garantia do Tempo de Serviço, e dá outras providências.

Casa Civil da Presidência da República - Subchefia para Assuntos Jurídicos. Lei no. 6.385, de 7 de dezembro de 1976, Brasília. Dispõe sobre o mercado de valores mobiliários e cria a Comissão de Valores Mobiliários.

Casa Civil da Presidência da República - Subchefia para Assuntos Jurídicos. Lei no. 6.404, de 15 de dezembro de 1976, Brasília. Dispõe sobre as Sociedades por ações.

Casa Civil da Presidência da República - Subchefia para Assuntos Jurídicos. Lei no. 8.036, de 11 de maio de 1990. Dispõe sobre o Fundo de Garantia do Tempo de Serviço, e dá outras providências.

Casa Civil da Presidência da República - Subchefia para Assuntos Jurídicos. Lei no. 8.100, de 5 de dezembro de 1990. Dispõe sobre medidas de fortalecimento do Sistema 
Casa Civil da Presidência da República - Subchefia para Assuntos Jurídicos. Lei no. 9.514, de 20 de novembro de 1997, Brasília. Dispõe sobre o Sistema de Financiamento Imobiliário, institui a alienação fiduciária de coisa imóvel e dá outras providências.

Casa Civil da Presidência da República - Subchefia para Assuntos Jurídicos. Lei no. 9.710, de 19 de novembro de 1998. Dispõe sobre o reajuste das prestações pactuadas nos contratos de financiamento firmados no âmbito do Sistema Financeiro da Habitação, vinculados ao Plano de Equivalência Salarial e dá outras providências.

Casa Civil da Presidência da República - Subchefia para Assuntos Jurídicos. Lei nº 10.150, de 21 de dezembro de 2000. Dispõe sobre medidas de fortalecimento do Sistema Financeiro Nacional e dá outras providências. Dispõe sobre a novação de dívidas e responsabilidades do Fundo de Compensação de Variações Salariais - FCVS, e dá outras providências.

Casa Civil da Presidência da República - Subchefia para Assuntos Jurídicos. Lei no. 10.931, de 02 de agosto de 2004. Dispõe sobre o patrimônio de afetação de incorporações imobiliárias, Letra de Crédito Imobiliário, Cédula de Crédito Imobiliário, Cédula de Crédito Bancário, altera o Decreto-Lei no 911, de 1 o de outubro de 1969, as Leis no 4.591, de 16 de dezembro de 1964, no 4.728, de 14 de julho de 1965, e no 10.406, de 10 de janeiro de 2002, e dá outras providências.

Casa Civil da Presidência da República - Subchefia para Assuntos Jurídicos. Lei no. 11.196, de 21 de novembro de 2005. Institui o Regime Especial de Tributação para a Plataforma de Exportação de Serviços de Tecnologia da Informação - REPES, o Regime Especial de Aquisição de Bens de Capital para Empresas Exportadoras - RECAP e o Programa de Inclusão Digital; dispõe sobre incentivos fiscais para a inovação tecnológica; e dá outras providências.

Casa Civil da Presidência da República - Subchefia para Assuntos Jurídicos. Medida Provisória no 460, de 30 de março de 2009. Dá nova redação aos arts. $4^{\circ}$ e $8^{\circ}$ da Lei no 10.931, de 2 de agosto de 2004, que tratam de patrimônio de afetação de incorporações imobiliárias, dispõe sobre o tratamento tributário a ser dado às receitas mensais auferidas pelas empresas construtoras nos contratos de construção de moradias firmados dentro do Programa Minha Casa, Minha Vida - PMCMV, atribui à Agência Nacional de Telecomunicações - ANATEL as atribuições de apurar, constituir, fiscalizar e arrecadar a Contribuição para o Fomento da Radiodifusão Pública, e dá outras providências. Prorrogação de Vigência pelo Ato do Pres. da Mesa do CN no 14, de 19 de maio de 2009. 
Casa Civil da Presidência da República - Subchefia para Assuntos Jurídicos. Medida

Provisória no. 1.635-16, de 12 de dezembro de 1997. Dispõe sobre a novação de dívidas e responsabilidades do Fundo de Compensação de Variações Salariais - FCVS, e dá outras providências.

Casa Civil da Presidência da República - Subchefia para Assuntos Jurídicos. Medida Provisória no. 1.635-17, de 13 de dezembro de 1998. Dispõe sobre a novação de dívidas e responsabilidades do Fundo de Compensação de Variações Salariais - FCVS, e dá outras providências.

Câmara da Reforma do Estado. Plano Diretor da Reforma do Aparelho do Estado. Brasília: Câmara da Reforma do Estado, 1995.

FGTS. CCFGTS. Resolução n. 460, de 14 de dezembro de 2004. Estabelece diretrizes para a aplicação dos recursos e a elaboração das propostas orçamentárias do FGTS, no período de 2005 a 2008.

FGTS. CCFGTS. Resolução n 518, de 7 de novembro de 2006. Altera e consolida a Resolução no 460, de 14 de dezembro de 2004, que dispõe sobre as diretrizes para a aplicação dos recursos e a elaboração das propostas orçamentárias do FGTS, no período de 2005 a 2008, e dá outras providências.

FGTS. CCFGTS. Resolução no 578, de 2 de dezembro de 2008. Autoriza a aquisição de cotas de Fundos de Investimento Imobiliário - Flls e de Fundos de Investimento em Direitos Creditórios - FIDCs e debêntures, complementarmente à aquisição de Certificados de Recebíveis Imobiliários - CRIs, e altera o subitem 6.1 do Anexo II da Resolução no 460, de 14 de dezembro de 2004.

FGTS. CCFGTS. CEF. Relatório de Gestão do Fundo de Garantia do Tempo de Serviço - Exercício 1999. Disponível em <http://www.caixa.gov.br/fgts>. Acesso em out 2008.

FGTS. CCFGTS. CEF. Relatório de Gestão do Fundo de Garantia do Tempo de Serviço - Exercício 2000. Disponível em <http://www.caixa.gov.br/fgts>. Acesso em out 2008.

FGTS. CCFGTS. CEF. Relatório de Gestão do Fundo de Garantia do Tempo de Serviço - Exercício 2001. Disponível em <http://www.caixa.gov.br/fgts>. Acesso em out 2008. FGTS. CCFGTS. CEF. Relatório de Gestão do Fundo de Garantia do Tempo de Serviço - Exercício 2002. Disponível em <http://www.caixa.gov.br/fgts>. Acesso em out 2008. FGTS. CCFGTS. CEF. Relatório de Gestão do Fundo de Garantia do Tempo de Serviço - Exercício 2003. Disponível em <http://www.caixa.gov.br/fgts>. Acesso em out 2008. 
. FGTS. CCFGTS. CEF. Relatório de Gestão do Fundo de Garantia do Tempo de Serviço

- Exercício 2004. Disponível em <http://www.caixa.gov.br/fgts>. Acesso em out 2008.

FGTS. CCFGTS. CEF. Relatório de Gestão do Fundo de Garantia do Tempo de Serviço - Exercício 2005. Disponível em <http://www.caixa.gov.br/fgts>. Acesso em out 2008.

FGTS. CCFGTS. CEF. Relatório de Gestão do Fundo de Garantia do Tempo de Serviço - Exercício 2006. Disponível em <http://www.caixa.gov.br/fgts>. Acesso em out 2008.

FGTS. CCFGTS. CEF. Relatório de Gestão do Fundo de Garantia do Tempo de Serviço - Exercício 2007. Disponível em <http://www.caixa.gov.br/fgts>. Acesso em out 2008.

FGTS. CCFGTS. CEF. Relatório de Gestão do Fundo de Garantia do Tempo de Serviço - Exercício 2008. Disponível em <http://www.caixa.gov.br/fgts>. Acesso em out 2008.

FGTS. CCFGTS. CEF. Ministério das Cidades. Ministério da Fazenda. Ministério do Trabalho e Emprego. Demonstrações Financeiras do FGTS - Relatório de Administração do FGTS - Exercício 2002. Disponível em <http://www.caixa.gov.br/fgts>. Acesso em out 2008.

FGTS. CCFGTS. CEF. Ministério das Cidades. Ministério da Fazenda. Ministério do Trabalho e Emprego. Demonstrações Financeiras do FGTS - Relatório de Administração do FGTS - Exercício 2003. Disponível em <http://www.caixa.gov.br/fgts>. Acesso em out 2008.

FGTS. CCFGTS. CEF. Ministério das Cidades. Ministério da Fazenda. Ministério do Trabalho e Emprego. Demonstrações Financeiras do FGTS - Relatório de Administração do FGTS - Exercício 2004. Disponível em <http://www.caixa.gov.br/fgts>. Acesso em out 2008.

FGTS. CCFGTS. CEF. Ministério das Cidades. Ministério da Fazenda. Ministério do Trabalho e Emprego. Demonstrações Financeiras do FGTS - Relatório de Administração do FGTS - Exercício 2005. Disponível em <http://www.caixa.gov.br/fgts>. Acesso em out 2008.

FGTS. CCFGTS. CEF. Ministério das Cidades. Ministério da Fazenda. Ministério do Trabalho e Emprego. Demonstrações Financeiras do FGTS - Relatório de Administração do FGTS - Exercício 2006. Disponível em <http://www.caixa.gov.br/fgts>. Acesso em out 2008.

FGTS. CCFGTS. CEF. Ministério das Cidades. Ministério da Fazenda. Ministério do Trabalho e Emprego. Demonstrações Financeiras do FGTS - Relatório de Administração do FGTS - Exercício 2007. Disponível em <http://www.caixa.gov.br/fgts>. Acesso em out 2008.

FGTS. CCFGTS. CEF. Ministério das Cidades. Ministério da Fazenda. Ministério do Trabalho e Emprego. Demonstrações Financeiras do FGTS - Relatório de Administração do FGTS - Exercício 2008. Disponível em <http://www.caixa.gov.br/fgts>. Acesso em out 2008. 
Ministério da Ação Social/SNH/DAP. Relatório Gerencial de Acompanhamento e Controle dos Programas Habitacionais PAIH/PEP/PROHAP/Cooperativas. Brasília: Ministério da Ação Social, 1992.

Ministério das Cidades. Cadernos MCidades Desenvolvimento Urbano 1 - Política Nacional de Desenvolvimento Urbano. Brasília, 2004.

Ministério das Cidades. Cadernos MCidades Desenvolvimento Urbano 4 - Política Nacional de Habitação. Brasília, 2004.

Ministério das Cidades. Secretaria Nacional de Habitação. Déficit habitacional no Brasil. 2007. Brasília: Ministério das Cidades/Secretaria Nacional de Habitação, 2009.

. Ministério das Cidades. Secretaria Nacional de Habitação. Plano Nacional de Habitação - PLANHAB. Brasília: Ministério das Cidades/Secretaria Nacional de Habitação, 2008.

Ministério de Estado da Fazenda - Banco Central do Brasil. Circular no. 3.152, de 20 de setembro de 2002, Brasília. Estabelece condições para a emissão de Letra de Crédito Imobiliário (LCl).

. Ministério de Estado da Fazenda - Banco Central do Brasil. Circular no. 3.239, de 27 de maio de 2004, Brasília. Dispõe sobre encaminhamento de dados relativos às aplicações de recursos provenientes de depósitos de poupança em financiamentos imobiliários.

. Ministério de Estado da Fazenda - Banco Central do Brasil. NOTA TÉCNICA: Alterações no direcionamento dos recursos captados em depósitos de poupança.

Ministério de Estado da Fazenda - Banco Central do Brasil. NOTA TÉCNICA: Alteração de procedimentos relativos aos acordos de compensação e liquidação de obrigações no âmbito do Sistema Financeiro Nacional.

Ministério de Estado da Fazenda - Banco Central do Brasil. NOTA TÉCNICA: Carta de garantia de aquisição para Certificados de Recebíveis Imobiliários (CRI) - Definição dos limites de financiamento para produção no âmbito do SFH.

Ministério de Estado da Fazenda - Banco Central do Brasil. NOTA TÉCNICA: Conceito de empresa ligada nos casos de aquisição de Certificados de Recebíveis Imobiliários (CRI).

Ministério de Estado da Fazenda - Banco Central do Brasil. NOTA TÉCNICA: Definição dos agentes financeiros integrantes do SFH.

Ministério de Estado da Fazenda - Banco Central do Brasil. NOTA TÉCNICA: Direcionamento de recursos de poupança - Aquisição de quotas de Fundo de Investimento Imobil- 
iário (FII) e Fundo de Investimento em Direitos Creditórios (FIDC) vinculados ao PIPS.

Ministério de Estado da Fazenda - Comissão de Valores Mobiliários. Instrução CVM no. 414, de 30 de dezembro de 2004, Brasília. Dispõe sobre o registro de companhia aberta para companhias securitizadoras de créditos imobiliários e de oferta pública de distribuição de Certificados de Recebíveis Imobiliários - CRI.

Ministério de Estado da Fazenda - Conselho Monetário Nacional. Resolução no. 401, de 22 de dezembro de 1976, Brasília.

Ministério de Estado da Fazenda - Conselho Monetário Nacional. Resolução nº. 790, de 11 de janeiro de 1983, Brasília.

Ministério de Estado da Fazenda - Conselho Monetário Nacional. Resolução no. 1.090, de 31 de janeiro de 1986, Brasília.

. Ministério de Estado da Fazenda - Conselho Monetário Nacional. Resolução no. 1.120, de 4 de abril de 1986, Brasília.

Ministério de Estado da Fazenda - Conselho Monetário Nacional. Resolução no. 1.339, de 15 de junho de 1987, Brasília.

Ministério de Estado da Fazenda - Conselho Monetário Nacional. Resolução no. 1.446, de 5 de janeiro de 1988, Brasília.

Ministério de Estado da Fazenda - Conselho Monetário Nacional. Resolução no. 1.655, de 26 de outubro de 1989, Brasília.

Ministério de Estado da Fazenda - Conselho Monetário Nacional. Resolução n 2.458, de 18 de dezembro de 1997. Dispõe sobre o direcionamento dos recursos captados em depósitos de poupança pelas entidades integrantes do Sistema Brasileiro de Poupança e Empréstimo (SBPE)

Ministério de Estado da Fazenda - Conselho Monetário Nacional. Resolução no. 2.461, de 26 de dezembro de 1997. Redefine regras para o contingenciamento do crédito ao setor público e estabelece limites para realização de operações.

Ministério de Estado da Fazenda - Conselho Monetário Nacional. Resolução no. 2.517, de 28 de junho de 1998, Brasília. Considera como valores mobiliários os Certificados de Recebíveis Imobiliários - CRI, de que trata o art.6º da Lei n.9.514, de 20 de novembro de 1997.

Ministério de Estado da Fazenda - Conselho Monetário Nacional. Resolução no. 
2.686, de 26 de janeiro de 2000, Brasília. Estabelece condições para a cessão de créditos a sociedades anônimas de objeto exclusivo e a companhias securitizadoras de créditos imobiliários.

Ministério de Estado da Fazenda - Conselho Monetário Nacional. Resolução no. 2.827, de 30 de março de 2001. Consolida e redefine as regras para o contingenciamento do crédito ao setor público.

Ministério de Estado da Fazenda - Conselho Monetário Nacional. Resolução nº. 2.951, de 19 de abril de 2002, Brasília. Dispõe sobre a obtenção de empréstimos ou financiamentos por parte de sociedades corretoras de títulos e valores mobiliários e de sociedades distribuidoras de títulos e valores mobiliários.

Ministério de Estado da Fazenda - Conselho Monetário Nacional. Resolução no. 3.005, de 26 de maio de 2003 Dispõe sobre o direcionamento dos recursos captados em depósitos de poupança pelas entidades integrantes do Sistema Brasileiro de Poupança e Empréstimo (SBPE).

. Ministério de Estado da Fazenda - Conselho Monetário Nacional. Resolução no. 3.111, de 31 de julho de 2003, Brasília. Dispõe sobre o conceito de empresa ligada nos casos de aquisição de Certificados de Recebíveis Imobiliários - CRI.

Ministério de Estado da Fazenda - Conselho Monetário Nacional. Resolução no. 3.112, de 31 de julho de 2003, Brasília. Dispõe sobre o cômputo das quotas de fundos de investimento imobiliário e de fundos de investimento em direitos creditórios, estruturados no âmbito do Programa de Incentivo à Implementação de Projetos de Interesse Social - PIPS, instituído pela Medida Provisória 122, de 2003, no direcionamento de recursos de depósitos de poupança.

Ministério de Estado da Fazenda - Conselho Monetário Nacional. Resolução no. 3.155, de 17 de dezembro de 2003, Brasília. Dispõe sobre o cômputo do valor das cartas de garantia de aquisição de Certificados de Recebíveis Imobiliários (CRI) no direcionamento dos recursos captados em depósitos de poupança nas condições que estabelece e dá outras providências.

Ministério de Estado da Fazenda - Conselho Monetário Nacional. Resolução no. 3.157, de 17 de dezembro de 2003, Brasília. Dispõe sobre a definição das instituições integrantes do Sistema Financeiro da Habitação (SFH).

Ministério de Estado da Fazenda - Conselho Monetário Nacional. Resolução no. 3.259, de 28 de janeiro de 2005, Brasília. Altera o direcionamento de recursos captados em depósitos de poupança pelas entidades integrantes do Sistema Brasileiro de Poupança e 
Ministério de Estado da Fazenda - Conselho Monetário Nacional. Resolução no. 3.177, de 8 março de 2004. Altera a fração prevista no art. $2^{\circ}$, inciso II, e no art. 30, inciso II, da resolução 3.005, de 2002, a remuneração dos recursos captados em depósitos de poupança recolhidos ao Banco Central do Brasil, bem como limita a aquisição de letras de crédito imobiliário e letras hipotecárias pelas instituições integrantes do Sistema Brasileiro de Poupança e Empréstimo (SBPE).

. Ministério de Estado da Fazenda - Conselho Monetário Nacional. Resolução no. 3.347, de 8 de fevereiro de 2006. Dispõe sobre o direcionamento dos recursos captados em depósitos de poupança pelas entidades integrantes do Sistema Brasileiro de Poupança e Empréstimo (SBPE).

Ministério de Estado da Fazenda - Conselho Monetário Nacional. Resolução no. 3.706, de 27 de março de 2009. Dispõe sobre a concessão de financiamentos imobiliários, o direcionamento dos recursos captados em depósitos de poupança pelas entidades integrantes do Sistema Brasileiro de Poupança e Empréstimo (SBPE), a realização de operações de microcrédito destinadas à população de baixa renda e a microempreendedores e altera a Resolução no 2.828, de 2001, que trata da constituição e do funcionamento de agências de fomento.

. Ministério de Estado da Fazenda - Receita Federal do Brasil. Instrução Normativa SRF n० 487, de 30 de dezembro de 2004. Dispõe sobre o imposto de renda incidente sobre os rendimentos e ganhos líquidos auferidos em operações de renda fixa e de renda variável e em fundos de investimentos. Alterada pela IN SRF 489/2005. Alterada pela IN RFB nº 822, de 12 de fevereiro de 2008

Senado Federal. Resolução Senado Federal nº. 40, de 9 de abril de 2002. Dispõe sobre os limites globais para o montante da dívida pública consolidada e da dívida pública mobiliária dos Estados, do Distrito Federal e dos Municípios, em atendimento ao disposto no art. 52, VI e IX, da Constituição Federal.

BRATT, Rachel G.; HARTMAN, Chester C; STONE, Michael E. A right to housing: foundation for a new social agenda. Philadel phia: Temple University Press, 2006.

BRENNER, Robert. O boom e a bolha: os Estados Unidos na economia mundial. Rio de Janeiro: Record, 2003.

BRESSER PEREIRA, Luiz Carlos. Do Estado patrimonial ao gerencial. In: SACHS, Ignacy; WILHEIM, Jorge; PINHEIRO, Paulo S. (Orgs.). Brasil: um século de transformações. São Paulo: Cia das Letras, 2001. 
BROLLO, Fernanda. Crédito Imobiliário e Déficit de Moradias: Uma Investigação dos Fatores Econômicos e Institucionais do Desenvolvimento Habitacional no Chile e no Brasil. 2004. Dissertação (Mestrado) - Escola de Economia de São Paulo, Fundação Getúlio Vargas, São Paulo, 2004.

BRUNHOFF, Suzanne de. A Instabilidade Monetária Internacional in CHESNAIS, François (Org.). A Finança Mundializada: raízes sociais e políticas, configuração, conseqüências. São Paulo: Boitempo, 2005, pp. 69-84.

CANÇADO, Patrícia; ARAGÃO, Marianna. Construtoras acumulam estoques de imóveis de mais de R\$ 25 bilhões. Jornal O Estado de São Paulo, São Paulo, 19 abr. 2009.

CARLSON, Eric et al. Habitação nos países em desenvolvimento. Cadernos do CENPHA 2. Rio de Janeiro: Centro Nacional de Pesquisas Habitacionais, 1967.

CARNEIRO, Dionísio Dias; GOLDFAJN, Ilan. A Securitização de Hipotecas no Brasil. Texto para discussão n426. Rio de Janeiro: Departamento de Economia da Pontifícia Universidade Católica, jun 2000. ; VALPASSOS, Marcus Vinicius F. Financiamento à Habitação e Instabilidade Econômica - Experiências Passadas, Desafios e Propostas para a Ação Futura. Rio de Janeiro: Fundação Getúlio Vargas, 2003.

CARNEIRO, Ricardo. A supremacia dos mercados e a política econômica do governo Lula. São Paulo: UNESP/FAPESP, 2006.

CARVALHAES, Marcelo La Motta. Análise de Fundos de Investimento em Participações com Aplicações em Empreendimentos Imobiliários. 2006. Monografia, MBA em Gerenciamento de Empresas e Empreendimentos de Construção Civil, Escola Politécnica da Universidade de São Paulo. São Paulo, 2006.

CARVALHO, Sônia N. e BRANCO SOBRINHO, Álvaro M. Notas sobre as tendências recentes da Política Nacional de Habitação Popular (versão preliminar). In: Congresso Nacional dos Sociólogos, Câmara Técnica 'Habitação', mimeo, ago 1992.

CASTRO, Carolina M. P. A explosão do autofinanciamento na produção da moradia em São Paulo nos anos 90. 1999. Tese (Doutorado) - Faculdade de Arquitetura e Urbanismo, Universidade de São Paulo. São Paulo, 1999.

CBIC. Balanço do setor de construção civil no Brasil em 1997 e perspectivas para 1998. Belo Horizonte: CBIC, jan1998. Disponível em <http://www.cbicdados.com.br/files/textos/039.pdf>. Acesso em out 2008. 
Diretrizes para a Reformulação do Sistema de Financiamento da Habitação. Belo Horizonte: CBIC, out 1996. Disponível em <http://www.cbicdados.com.br/files/textos/045.pdf>. Acesso em out 2008.

A indústria da construção brasileira no início do século XXI: análise e perspectivas. Belo Horizonte: CBIC, out 1998. Disponível em: <http://www.cbicdados.com.br/files/textos/034. pdf>. Acesso em out 2008.

Retrospectiva da economia nacional e do setor de construção em 2006 e perspectivas para 2007. Brasília: CBIC, 2006. Disponível em: <http://www.cbicdados.com.br/files/textos/049.pdf>. Acesso em out 2008.

O setor da construção civil no plano real: análise e perspectivas. Belo Horizonte, set. 1994. Disponível em: <http://www.cbicdados.com.br/files/textos/053.pdf>. Acesso em out 2008.

CHESNAIS, François. O capitalismo tentou romper seus limites históricos e criou um novo 1929, ou pior! Carta Maior. São Paulo, out 2008. Disponível em: < http://www.cartamaior. com.br/templates/materiaMostrar.cfm?materia id=15284>. Acesso em mar 2009.

O Capital Portador de Juros: acumulação, internacionalização, efeitos econômicos e políticos in CHESNAIS, François (Org.). A Finança Mundializada: raízes sociais e políticas, configuração, conseqüências. São Paulo: Boitempo, 2005, pp.35-67.

CHIQUIER, LoÏc, HASSLER, Olivier; LEA, Michael. Mortgage Securities in Emerging Markets. World Bank Policy Research Working Paper, n. 3370, ago. 2004. Disponível em: <http://ssrn.com/ab-

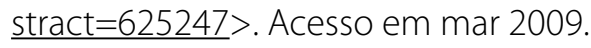

CRACKS in the façade: America`s Riskiest Mortgages are Crumbling. How Far Will the Damage Spread? The Economist, Londres, 22 mar 2007.

CRUZ, Renato. A fórmula que destruiu Wall Street - instituições financeiras calculavam risco de hipotecas de um jeito que só funcionava com mercado em alta. Jornal O Estado de São Paulo, São Paulo, 15 de março de 2009, Caderno Economia B11.

D'AMBROSIO, Daniela. Novo cenário da construção. Jornal Valor Econômico, São Paulo, 13 abr 2009, p. D1.

DELFIM NETTO, Antonio. Os subprimes. Jornal Valor Econômico, São Paulo, 28 de agosto de 2007, p. A3.

DINIZ, Eli; AZEVEDO, Sérgio (Orgs.). Reforma do Estado e Democracia no Brasil. Rio de Janeiro: FGV, 1997. 
DOWBOR, Ladislau. A Crise Financeira sem Mistérios. São Paulo, 22. jan 2008. Disponível em <http://dowbor.org/crise/09crisesemmisterios.pdf >. Acesso em mar 2009.

DOWNES, John; GOODMAN, Jordan E. Dictionary of Finance and Investment Terms. Barrons, 2003.

DRAIBE, Sônia. As Políticas Sociais do Regime Militar Brasileiro: 1964-84. In: SOARES, GLÁUCIO A.D; D `ARAÚJO, MARIA CELINA. 21 Anos de Regime Militar - Balanços e Perspectivas. Rio de Janeiro: Fundação Getúlio Vargas, 1994.

ENDIVIDADA, Klabin Segall está à venda e já têm interessados. Jornal Valor Econômico, São Paulo, 27 abr 2009, p.B6.

EXAME. A construção de um país moderno. São Paulo: Abril, ed. 903, ano 41, no. 19, 2007. Edição especial.

FAGNANI, Eduardo. Ajuste econômico e financiamento da política social brasileira: nota sobre o período 1993/98. In: Revista de Economia e Sociedade. Campinas: IE-Unicamp, (13), p. 155-178, dez 1999.

FERNANDES, Antônio A. G. O Sistema Financeiro Nacional Comentado: Instituições Supervisoras e Operadoras do SFN, Políticas Econômicas, Operações Financeiras e Administração de Risco. São Paulo: Saraiva, 2006.

FERNADES, Florestan. Nova República? Rio de Janeiro: Jorge Zahar Editor, 1986.

FERREIRA, João S. W. São Paulo: O Mito da Cidade Global. 2003. Tese (Doutorado) - Faculdade de Arquitetura e Urbanismo da Universidade de São Paulo. São Paulo, 2003.

FIGUEIREDO, Marcus; FIGUEIREDO, Argelina M. C. Avaliação política e avaliação de políticas: um quadro de referência teórica. São Paulo: IDESP, 1986.

FINEP-GAP. Habitação Popular, inventário da ação governamental. Rio de Janeiro: FINEP, 1985.

. Habitação Popular, inventário da ação governamental - Complementação: 1984-1986. Rio de Janeiro: FINEP, 1988.

FIORI, José Luis (Org.). A globalização ea novíssima dependência. In Em Busca do Dissenso Perdido. Rio de Janeiro: Insight, pp. 215-229, 1995.

Estado e moedas no desenvolvimento das nações. Petrópolis: Vozes, 1999.

O vôo da coruja: uma leitura não liberal da crise do Estado desenvolvimentista. Rio de 
Janeiro: EdUERJ, 1995.

;TAVARES, Maria da Conceição (Orgs.). Poder e dinheiro: uma economia política da urbanização. Petrópolis: Vozes, 1997.

.; MEDEIROS, Carlos (Orgs.). Polarização mundial e crescimento. Petrópolis: Vozes, 2001.

FIX, Mariana. Parceiros da exclusão:duas histórias da construção de uma 'nova cidade' em São Paulo: Faria Lima é Água Espraiada. São Paulo: Boitempo, 2001.

São Paulo cidade global: fundamentos financeiros de uma miragem. São Paulo: Boitempo, 2007.

FLACH, Natalia. Governo precisa incentivar securitização. Jornal Gazeta Mercantil. São Paulo, 9 abr. 2009, p. 2.

FORTUNA, Eduardo. Mercado financeiro: produtos e serviços. Rio de Jeneiro: Qualitymark, 2005.

FRANÇA, Valéria. População de favelas cresce 2 vezes mais rápido que a de SP em geral. Jornal O Estado de São Paulo, São Paulo, 1 mai 2009, p. C1.

FREITAS, ELEUSINA L. H. Como qualificar conjuntos habitacionais populares. 2002. Dissertação (Mestrado) - Programa de Pós-Graduação em Urbanismo, Pontifícia Universidade Católica de Campinas. Campinas, 2002.

FRIEDMAN, Jack P; HARRIS, Jack C.; LINDEMAN, J. Bruce. Dictionary of Real Estate Terms. Barrons, 2004.

FUNDAÇÃO GETÚLIO VARGAS. O Crédito Imobiliário no Brasil - Caracterização e Desafios. São Paulo: FGV-Projetos, 2007.

FUNDAÇÃO JOÃO PINHEIRO. Centro de Estudos Econômicos e Regionais. Avaliação do Programa de Erradicação de Sub Habitação - PROMORAR: relatório conclusivo. Belo Horizonte: FJP, 1990.

Déficithabitacional no Brasil. Brasília: Ministério do Planejamento e Orçamento/SEPURB, 1995.

FURTADO, Celso. Introdução ao desenvolvimento: enfoque histórico-estrutural. Rio de Janeiro: Paz e Terra, 2000.

Prefácio a nova economia política. Rio de Janeiro: Paz e Terra, 1977. 
GRAMLICH, Edward M. Subprime mortgages: America's latest boom and bust. Washington:

The Urban Institute Press, 2007.

GRANDES REPORTAGENS-MEGACIDADES. São Paulo: O Estado de São Paulo, ago. 2008. Edição especial.

GRANDI, Sônia L. Desenvolvimento da indústria da construção no Brasil: mobilização e acumulação do capital e da força de trabalho. 1985. Tese (Doutorado) - Faculdade de Filosofia, Letras e Ciências Humanas, Universidade de São Paulo. São Paulo,1985.

GRAU, Eros Roberto. A ordem econômica na Constituição de 1988. São Paulo: Malheiros, 2008.

GREEN, Richard K.; MALPEZZI, Stephen. A primer on U.S. housing markets and housing policy. Washington: The Urban Institute Press, 2003.

GREENSPAN, Alan. FED não tem culpa pela bolha imobiliária. Jornal Folha de São Paulo, São Paulo, 10 de abril de 2008, Caderno Dinheiro.

GUHA, Krishna. EUA se preparam para a 2a dose recessiva. Jornal Folha de São Paulo (matéria originalmente publicada no Jornal Financial Times), São Paulo, 20 de julho de 2008, caderno Dinheiro.

GUTTMANN, Robert; PLIHON, Dominique. O endividamento do consumidor no cerne do capitalismo conduzido pelas finanças. Economia e Sociedade, Campinas, v. 17, número especial, p. 575-610, dez 2008.

HACKWORTH, Jason; WILY, Elvin. Social Polarization and the Politics of Low Income Mortgage Lending in the United States. Geografiska Annaler, Series B, Human Geography, Vol. 85, № 3. Blackwell Publishing, 2003. Disponível em: <http://www.jstor.org/stable/3554323>. Acesso em mar 2009.

HARMS, Hans. Historical Perspectives on the Practice and Purpose of Self-Help Housing. In:WARD, Peter M. (Ed.) Self-Help Housing, a critique. London: Mansell Publishing Limited/Alexandrine Press, 1982.

HARTMAN, Chester; ROSENBERRY, Sara. Housing issues of the 1990s. Nova York: Praeger, 1989.

HARVEY, David. A condição pós-moderna. São Paulo, Loyola, 1992.

. A justiça social e a cidade. São Paulo: Hucitec, 1980. 
Espaços de esperança. São Paulo: Loyola, 2004.

O neoliberalismo: história e implicações. São Paulo: Loyola, 2008.

O trabalho, o capital e o conflito de classes em torno do ambiente construído nas sociedades capitalistas avançadas. In: Revista Espaço e Debates, n’. 6. São Paulo: Cortez, jun/ set 1982.

INSTITUTO JOAQUIM NABUCO. Avaliação de programas habitacionais de baixa renda: região metropolitana de Recife. Recife: $\mathrm{BNH}, 1979$.

IPT. Experiência de Auto-ajuda e Ajuda Mútua, relatório de pesquisa. Projeto de Autoconstrução João Paulo II, PROAFA, s/d.

IUPERJ. Análise comparativa de pesquisa de avaliação de programas habitacionais de baixa renda. Rio de Janeiro: $\mathrm{BNH}, 1980$.

KAPLAN, Marshall; MEIN, John. A Report Based on the Proceedings of The Brazil-U.S. Aspen Global Forum April 8 - 11, 1999. American Chamber of Commerce -- São Paulo and Institute for Policy Implementation / Graduate School of Public Affairs / University of Colorado at Denver. Mimeo, 1999. Disponível em <http://74.125.47.132/search?q=cache:yPx5uvJs604J:www. housingfinance.org/pdfstorage/SAmerica opportun.pdf+KAPLAN+Marshall+MEIN+John+April+8+ 11+1999+American+Chamber+of+Commerce+S\%C3\%A30+Paulo+and+Institute+for+Policy+Imp lementation+A+Report+Based+on+the+Proceedings+of+The+Brazil+US+Aspen+Global+Forum\&

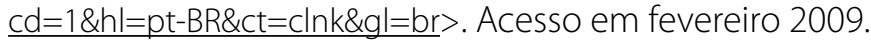

KÊNIA, Miriam. Emissões de Certificados de Recebíveis Imobiliários já superam o total de 2007 e prometem novo recorde. Crédito Imobiliário e interesse dos bancos dão fôlego aos títulos. Revista Capital Aberto, ano 5, n. 60, ago. 2008, p. 12-14. São Paulo: Editora Capital Aberto, 2008.

KONINGS, Martijn; PANITCH, Leo. Myths of Deregulation. New Left Review, no. 57, mai-jun 2009. Glasgow: Bell \& Bain, 2009.

KOWARICK, Lúcio. A Espoliação Urbana. Rio de Janeiro: Paz e Terra, 1980.

LIMA JR., João da Rocha. Evolução e Inovação: Reflexões para Empresas de Real Estate. Carta do Núcleo de Real Estate, Escola Politécnica, Universidade de São Paulo, n. 9-07, out-dez 2007, São Paulo, 2008.

Fundos de Investimento Imobiliário, com Portfólio de Base imobiliária: Notas sobre 
a Depreciação do Ativo. Boletim Técnico do Departamento de Engenharia de Construção Civil ,

Escola Politécnica, Universidade de São Paulo BT/PCC/187. São Paulo: EPUSP, 1997.

Fundos de Investimento Imobiliário e Títulos de Investimento de Base Imobiliária. Boletim Técnico do Departamento de Engenharia de Construção Civil - Escola Politécnica da Universidade de São Paulo BT/PCC/130. São Paulo: EPUSP, 1994.

- O Grau de Investimento e os Preços das Ações das Empresas de Real Estate Listadas na Bovespa. Carta do Núcleo de Real Estate - Departamento de Engenharia de Construção Civil da Escola Politécnica da Universidade de São Paulo, n. 12-08, São Paulo, 2008.

Instrumentos de investimento em empreendimentos habitacionais no Brasil: a questão estrutural. Boletim Técnico do Departamento de Engenharia de Construção Civil - Escola Politécnica da Universidade de São Paulo BT/PCC/354. São Paulo: EPUSP, 2004.

Novos produtos financeiros e o mercado imobiliário: investimentos via títulos de securitização. Palestra proferida no 10. Seminário da Latin America Real Estate Society, set. 1999.

Precificação de permutas. Carta do Núcleo de Real Estate, n. 11-08 - Departamento de Engenharia de Construção Civil - Escola Politécnica da Universidade de São Paulo, São Paulo, 2008.

Recursos para Empreendimentos Imobiliários no Brasil - Debêntures e Fundos. Boletim Técnico do Departamento de Engenharia de Construção Civil - Escola Politécnica da Universidade de São Paulo BT - 28/90. São Paulo: EPUSP, 1990.

Securitização de Portfólios de Base Imobiliária. Boletim Técnico do Departamento de Engenharia de Construção Civil - Escola Politécnica da Universidade de São Paulo BT/PCC/99. São Paulo: EPUSP, 1999.

Os Sistemas Operacionais para Securitização de Portfólios Imobiliários e de Base imobiliária Via Debêntures. Boletim Técnico do Departamento de Engenharia de Construção Civil - Escola Politécnica da Universidade de São Paulo BT/PCC/186. São Paulo: EPUSP, 1997.

Títulos de investimento com lastro em ativos: o mercado brasileiro à espera de um líder. Revista Álvares Penteado, v.1, n.3, set. 1999, FECAP - Fundação Escola de Comércio Alvares Penteado, São Paulo, 1999.

; ALENCAR, Cláudio Tavares de. Comportamento das Ações das Empresas de Real Estate na Bovespa. Carta do Núcleo de Real Estate - Departamento de Engenharia de Construção Civil da Escola Politécnica da Universidade de São Paulo, n. 7-07, São Paulo, 2007. 
; ALENCAR, Cláudio Tavares de. O Mercado de Edifícios de Escritórios para Locação em São Paulo: Ciclos para a Absorção do Estoque e para a Retomada da Atratividade do Investimento. Estudos Econômicos da Construção, v. 6, n. 1 (9), [2002-2003]. São Paulo: Sinduscon-SP, 2004.

; ALENCAR, Cláudio Tavares de. O Valor das Empresas de Real Estate do Novo Mercado. Carta do Núcleo de Real Estate - Departamento de Engenharia de Construção Civil da Escola Politécnica da Universidade de São Paulo, n. 14-08, São Paulo, 2008.

; VERONEZI, Ana Beatriz Poli. Condições para Validação de Construção de Habitação Popular no Brasil. In: Anais do VII Seminário Internacional da Latin American Real Estate Society. São Paulo, 2007.

LOJKINE, Jean. O Estado Capitalista e a Questão Urbana. São Paulo: Martins Fontes, 1981.

LUCENA, José M.P. O Mercado Habitacional no Brasil. Rio de Janeiro: FGV,1985.

MACEDO, Bernardo Gouthier. Desenvolvimento Econômico: a atualidade da economia política cepalina. 2007. Tese (Doutorado). Instituto de Economia, Universidade Estadual de Campinas. Campinas, 2007.

MARICATO, Ermínia. Brasil, cidades: alternativas para a crise urbana. São Paulo: Vozes, 2001. . Cidades Brasileiras: um Balanço. São Paulo: 2005.

. As idéias fora do lugar e o lugar fora das idéias: planejamento urbano no Brasil. In: ARANTES, Otília;VAINER, Carlos; MARICATO, Ermínia. A cidade do pensamento único: desmanchando consensos. Petrópolis: Vozes, 2000.

Indústria da Construção e Política Habitacional. 1983. Tese (Doutorado) - Faculdade de Arquitetura e Urbanismo, Universidade de São Paulo. São Paulo, 1983.

Metrópole na Periferia do Capitalismo. São Paulo, Hucitec, 1996. . Política habitacional no regime militar. Petrópolis: Vozes, 1987.

Política Urbana e de Habitação Social. Revista Praga Estudos Marxistas, São Paulo: Hucitec, no 6, p. 67-78, set 1998.

A produção capitalista da casa (e da cidade) no Brasil Industrial. São Paulo: AlfaÔmega, 1979.

MASSONETO, Luis Fernando. O direito financeiro no capitalismo contemporâneo: a emergência de um novo padrão normativo. 2006. Tese (Doutorado) - Faculdade de Direito, Universidade 
de São Paulo. São Paulo, 2006.

MATTOSO, Jorge. Crise e Setor Imobiliário. Jornal Correio Brasiliense, Brasília, 27 de outubro de 2008, p. 19

; MUNIZ, Suely. Brasil consolida política antissubprime. Jornal Correio Brasiliense, 19 de março de 2009.

MÁXIMA financeira lança 1․ Fundo de recebíveis no país. Jornal Valor Econômico, São Paulo, 23 set 2002.

MEDEIROS, Carlos Aguiar de. Instituições, Estado e Mercado no Processo do Desenvolvimento Econômico. Revista de Economia Contemporânea, Rio de Janeiro, v. 5, no. 1, p. 49-77, 2001.

MELLO, João Manoel Cardoso de. Prólogo. In: TAVARES, Maria da Conceição; FIORI, José Luís (Orgs.). Poder e Dinheiro: uma economia política da globalização. Petrópolis: Vozes, 1997, p. $15-24$.

MELO, Marcus A. B. C. Anatomia do Fracasso: Intermediação de Interesses e a Reforma das Políticas Sociais na Nova República. DADOS-Revista de Ciências Sociais, Rio de Janeiro, v. 36, no. 1, 1993.

- Classe, burocracia e intermediação de interesses na formação da política de habitação. Revista Espaço e Debates, São Paulo, no. 24, 1988.

. Estruturação intra-urbana, regimes de acumulação e sistemas Financeiros da habitação: Brasil em perspectiva comparada. Revista Espaço e Debates, São Paulo, no. 31, 1990.

Políticas Públicas e Habitação Popular: continuidade e ruptura, 1979-1988. Revista de Administração Municipal, Rio de Janeiro, v. 36, no. 191, p. 44-57, abr/jun 1989.

Regimes de Acumulação, Estado e articulação de interesses na produção do espaço construído (Brasil, 1940-1988). In: VALLADARES, L.; PRETECEILLE, E.(Coords.) Reestruturação urbana: tendências e desafios. São Paulo: Nobel, 1990.

MUSSE, Ricardo. Observações sobre o desastre econômico. Revista Eletrônica Trópico, São Paulo, 28 out. 2008. Acesso em jun 2009.

NAHAS, Sônia. Programas federais para baixa renda executados com recursos orçamentários. Mimeo $s / n, s / l, s / d$.

NEE, Victor. The New Institutionalisms in Economics and Sociology. In: SMELSER, Neil; SWED- 
BERG, Richard (orgs.). The Handbook of Economic Sociology. New Jersey: Princeton University Press, 2001.

NEPP/IE. Brasil 1985. Relatório sobre a situação social do país. v. 2. Campinas: Ed. Unicamp, 1986.

NEPP/UNICAMP. Sub projeto 3: Avaliação do Plano de Ação Imediata para Habitação. Campinas: NEPP/UNICAMP, 1991.

NETO, Eleutério Rodriguez. O "Social" na Nova República. Revista de Administração Pública, n. 21(4), p. 16-23, out-dez, 1987.

NOVELLI, José Marcos N. Instituições, política e idéias econômicas: o caso do Banco Central do Brasil (1965-1998). São Paulo: Annablume; FAPESP, 2001.

NUSDEO, Fábio. Curso de Economia - Introdução ao Direito Econômico. São Paulo: Editora Revista dos Tribunais, 2005

O'DONNELL, Guillermo. Transição Democrática e Políticas Sociais. Revista de Administração Pública. Rio de Janeiro, v. 21, nº. 4, p. 9-16, out/dez 1987.

OEA-Departamento de Asuntos Sociales. La Vivienda en America Latina y el Caribe: componentes para una posible estrategia. In: Anais do Seminário Internacional sobre Autoconstrução e ParticipaçãoSocial. Curitiba: BNH, 1986.

OLIVEIRA, Francisco de. Acumulação Capitalista, Estado e Urbanização: A Nova Qualidade do Conflito de Classes. Revista Contraponto. Rio de Janeiro, v. 1, no. 1, p. 5-13, 1976.

A economia política da social democracia. Revista USP, São Paulo, no. 17, p. 136-143, 1993.

. Crítica à razão dualista - O ornitorrinco. São Paulo: Boitempo, 2003.

_. Os direitos do antivalor: a economia política da hegemonia imperfeita. Petrópolis: Vozes, 1998.

ON A GAMBLING Expedition: Constraints at Home Push China`s Banks into Risky Foreign Assets. The Economist, Londres, 30 ago 2007.

OSEKI, Jorge H. Algumas tendências da construção civil no Brasil. 1983. Dissertação (Mestrado) - Faculdade de Arquitetura e Urbanismo, Universidade de São Paulo, São Paulo, 1983.

PAULANI, Leda Maria. Bolhas brasileiras. Jornal do Conselho Regional de Economia do Rio de Janeiro. Rio de Janeiro, dez 2008. 
PAVINI, Angelo. O mundo fora de controle. Jornal Valor Econômico, São Paulo, 17 ago. 2007.

PENIDO DE FREITAS, Maria Cristina. Racionalidade da Regulamentação e Supervisão Bancária: uma interpretação heterodoxa. In: SOBREIRA, Rogério (Org.). Regulação financeira e bancária. São Paulo: Atlas, 2005.

PENIN, Guilherme; FERREIRA, Tiago. Can It Happen to Us? O Crédito Imobiliário no Brasil e as Possibilidades de Repetirmos a Crise Norte-americana. Informações FIPE, nº. 326. São Paulo: FIPE, 2007.

PEREIRA, Caio Mário da Silva. Instituições de Direito Civil - Volume IV - Direitos Reais. Rio de Janeiro: Forense, 2009.

PHILLIPS, Michael M. Como a casinha e sua grande hipoteca contribuíram para a crise. Jornal O Estado de São Paulo (tradução de The Wall Street Journal of Americas), São Paulo, 5 jan 2009.

PINHEIRO, Maurício Mota Saboya. O papel dos Fundos Parafiscais no Fomento: FGTS e FAT. Texto para Discussão №. 485, IPEA, Brasília, 1997.

PIZZA JR., Wilson. Ação Institucional de governo no setor habitacional. Revista de Administração Municipal. Rio de Janeiro, v. 36, nº. 191, p.36-43, abr-jun 1989.

PLOTKIN, Sydnei; SCHEUERMAN, William E. Private Interest, public spending: balanced budget conservatism and the fiscal crisis. Boston: South End Press, 1994.

POLLOCK, Alex J. Simplicity Versus Complexity in the Evolution of the Housing Finance System. Housing Finance International, s/l: Intl Union for Housing Finance, mar 1994.

PRADILLA, Emilio. El problema de la vivienda em América Latina. Quito: Centro de Investigación CIUDAD, 1983.

PRADO, Eleutério S.; PELIN, Eli R. Moradia no Brasil, reflexões sobre o problema habitacional brasileiro. São Paulo: CBMM/FIPE, 1993.

RECEBIVVEIS: fundo é alternativa para crédito mais barato. Jornal do Comércio, Rio de Janeiro, p. B2, 25 out 2002.

REVISTA DO SFI. São Paulo: ABECIP, ano 11, №. 24, 2007. São Paulo: ABECIP, ano 9, no. 19, 2005. São Paulo: ABECIP, ano 8, n’. 18, 2004. 
REVISTA TREVISAN. São Paulo: Trevisan Auditores e Consultores, ano 7, n. 135, 1999. Edição Especial Construbusiness.

RIBEIRO, Luiz César de Queiroz (Org.). Metrópoles: entre a coesão e a fragmentação, a cooperação e o conflito. Rio de Janeiro: FASE, 2004.

; AZEVEDO, Sérgio de. A crise da moradia nas grandes cidades: da questão da habitação à reforma urbana. Rio de Janeiro: Editora UFRJ, 1996.

ROCKY Terrain Ahead: How Much Will the Credit Crunch Hurt the World Economy. The Economist, Londres, 30 ago 2007.

ROSSBACH, Ana Cláudia M. C. Financiamento habitacional no Brasil. 2005. Dissertação (Mestrado) - Faculdade de Economia, Pontifícia Universidade Católica de São Paulo. São Paulo, 2005

ROSSETO, Rossella. Organismos Internacionais e a auto-construção: análise e reflexões sobre as políticas de habitação para população de baixa renda. 1993. Dissertação (Mestrado) - Faculdade de Arquitetura e Urbanismo da Universidade de São Paulo. São Paulo, 1993.

SACHS, Céline. São Paulo: Políticas Públicas e Habitação Popular. São Paulo: EDUSP, 1999.

SANTOS, Cláudio Hamilton M. Políticas Federais de Habitação no Brasil: 1964/1998. Texto para discussão n. 654 IPEA, Brasília, jul 1999.

SAULE JR., Nelson. A Proteção Jurídica da Moradia nos Assentamentos Irregulares. São Paulo: Sérgio Antonio Fabris Editor, 2004.

SCHWARTZ, Alex F. Housing policy in the United States: an introduction. Nova York: Routledge, 2006

SILVA, Ana Amélia (Org.). Moradia e Cidadania: um debate em movimento. São Paulo: Pólis, 1994.

SILVA, Pedro Eurico de Barros e. Habitação Popular: Desafio para uma Política de Governo. Revista de Administração Municipal. Rio de Janeiro, v. 36, no. 193, p. 60-65, out-dez 1989.

SIMONSEN, Mário H. Instabilidade macroeconômica e financiamento habitacional. Habitação e Poupança, São Paulo, ABECIP, dez 1990.

SINGER, Paul. Desenvolvimento Econômico e Evolução Urbana. São Paulo: Nacional, 1974. 
SOUZA, Herbert de. A Nova República e as Políticas Sociais. Revista de Administração Pública. Rio de Janeiro, v. 21, no. 4, p.24-30, out/dez 1987.

SOUZA, Maria Teresa X. Relatório da política habitacional 1991-1996. Trabalho Programado 2. Curso de pós-graduação FAU-USP. São Paulo, ago 1998.

TAVARES, Maria da Conceição. Ciclo e crise: o movimento recente da industrialização brasileira. Campinas: Unicamp, 1998.

. Império, território e dinheiro. In FIORI, José Luís (Org.) Estados e Moedas no Desenvolvimento das Nações. Petrópolis: Vozes, 1999, pp. 449-489.

Os novos 'donos do poder' [on line]. Disponível em <abordo.com.br/mctavares $>$. Acesso em maio de 2002.

. A Retomada da Hegemonia Norte-Americana. In TAVARES, Maria da Conceição; FIORI, José Luís (Orgs.). Poder e Dinheiro: uma economia política da globalização. Petrópolis: Vozes, 1997, pp.27-53.

; BELLUZZO, Luiz Gonzaga. A Mundialização do Capital e a Expansão do Poder Americano. In FIORI, José Luís (Org.). O Poder Americano. Petrópolis: Vozes, 2004, pp. 111-138.

; MELIN, Luiz Eduardo. Pós-escrito 1997: A Reafirmação da Hegemonia Norte-Americana. In TAVARES, Maria da Conceição; FIORI, José Luís (Orgs.). Poder e Dinheiro: uma economia política da globalização. Petrópolis: Vozes, 1997, pp.55-86.

; MIRANDA, Jose Carlos. Brasil: estratégias da conglomeração. In FIORI, José Luís (Org.) Estados e Moedas no Desenvolvimento das Nações. Petrópolis: Vozes, 1999, pp. 449-489.

THE LONG and the Short of It: A Complex System, but a Simple Problem. The Economist, Londres, 30 ago 2007.

THE TROUBLE with the Housing Market: After the Great Global Business, the Hangover Is Kicking in. Especially in America. The Economist, Londres, 22 mar 2007.

TOPALOV, Christian. Les promoteurs immobiliers; contribuition à l`analyse de la production capitaliste du logement en France. Paris: Mouton, 1974.

TRAVAGLINI, Fernando. Caixa negocia com governo a primeira emissão de CRI. Valor Econômico, São Paulo, 27 jun. 2008. . Emissões de CRI batem recorde. Jornal Valor Econômico, São Paulo, 31 jul. 2008. 
Paulo, 14 ago. 2007.

TURNER, John F.C. Vivienda, todo el poder para los usuarios. Madrid: Hermann Blume, 1977.

UFRJ/IEI/NÚCLEO DE PESQUISAS EM POLITICAS URBANAS. Sistema Financeiro da Habitaçãoe programas habitacionais alternativos: diagnóstico e perspectivas. Rio de Janeiro: UFRJ, 1989.

UNCHS-Habitat. Community participation in the execution of low-income housing projects. Nairobi: ONU, 1984.

UNCHS-Habitat. Promoting organizes self-help through cooperative modes of participation. Nairobi: ONU, 1984.

VALLADARES, Lícia (Org.) Habitação em questão. Rio de Janeiro: Zahar, 1980.

Políticas Alternativas de Habitação Popular: um vôo sobre a literatura internacional. Espaço e Debates, São Paulo, no. 16, 1985.

Repensando a Habitação no Brasil. Rio de Janeiro: IUPERJ / Zahar, 1982.

VALLADARES, Lícia; SANT'ANNA, Maria J.G. (Org.) 1001 teses sobre o Brasil urbano (1940-1989). Rio de Janeiro : luperj, 1991.

VALOR FINANCEIRO. São Paulo: Valor Econômico, ano 8, n. 9, julho de 2009. Edição especial Bancos Públicos.

VALOR SETORIAL. São Paulo: Valor Econômico, novembro de 2007. Edição especial Infra-Estrutura Urbana.

São Paulo: Valor Econômico, maio de 2008. Edição especial Mercado Imobiliário.

VAN ORDER, Robert. Public Policy and Secondary Mortgage Markets. Curso "Housing Finance in Emerging Markets: Policy and Regulatory Challenges", Washington: Banco Mundial, 10-13 mar 2003.

VARSANO, Ricardo. O impacto da reforma constitucional sobre as receitas estaduais e municipais. Revista de Administração Municipal, Rio de Janeiro, v. 36, no. 193, out/dez 1989.

VEDROSSI, Alessandro Olzon. A securitização de Recebíveis Imobiliários: Uma Alternativa de Aporte de Capitais para Empreendimentos Residenciais no Brasil. 2002. Dissertação (Mestrado) - Departamento de Engenharia de Construção Civil, Escola Politécnica da Universidade de São Paulo. São Paulo, 2002. 
VERONEZI, Ana Beatriz P. Condições para Validação de Habitação Popular no Brasil. Revista Construção Mercado, n’. 80, p. 24-28, São Paulo, mar 2008.

WARD, Peter M. (Ed.) Self-Help Housing, a critique. London: Mansell Publishing Limited/Alexandrine Press, 1982.

WILLIAMS, Richard; NESIBA, Reynold \& MCCONNEL, Eileen Diaz. The Changing Face of Inequality in Home Mortgage Landing. Social Problems, v. 52, n. 2, University of California Press: 2005. Disponível em: <http://www.jstor.org/stable/4488118>. Acesso em mar 2009.

WORLD BANK. Building Institutions for Markets. Nova York: Oxford University Press, 2002.

WORLD BANK. International Trends in Housing Finance: Relevancy for Brazil?. In: BANCO CENTRAL DO BRASIL. Conferência Internacional de Crédito Imobiliário; nov. 2007, Salvador, Brasil.

Housing Finance in Emerging Markets: Policy and Regulatory Challenges, curso promovido pelo Departamento de Operações e Políticas do Setor Financeiro do Banco Mundial, 10-13 mar. 2003.

Cities in Transition: World Bank Urban and Local Government Strategy. Washington: The World Bank, 2000.

; CAIXA ECONÔMICA FEDERAL. Subsídios e financiamentos habitacionais como instrumentos de política de habitação popular. Curso proferido pela Dra. Marja Hoeek Smith. Brasília, 2002.

YAZBEK, Otavio. Regulação do Mercado financeiro e de capitais. Rio de Janeiro: Elsevier, 2007. 